\author{
UNIVERSIDADE DE SÃO PAULO \\ FACULDADE DE FILOSOFIA, LETRAS E CIÊNCIAS \\ HUMANAS \\ DEPARTAMENTO DE LETRAS ORIENTAIS \\ PROGRAMA DE ESTUDOS JUDAICOS E ÁRABES \\ ESTUDOS JUDAICOS
}

JOSÉ RIBEIRO NETO

\title{
A INFLUÊNCIA DA TRADIÇÃO NA TRADUÇÃO E INTERPRETAÇÃO DE \\ ISAÍAS 52.13-53.12
}

Versão Corrigida

São Paulo

2014 


\author{
UNIVERSIDADE DE SÃO PAULO \\ FACULDADE DE FILOSOFIA, LETRAS E CIÊNCIAS \\ HUMANAS \\ DEPARTAMENTO DE LETRAS ORIENTAIS \\ PROGRAMA DE ESTUDOS JUDAICOS E ÁRABES \\ ESTUDOS JUDAICOS
}

JOSÉ RIBEIRO NETO

\title{
A INFLUÊNCIA DA TRADIÇÃO NA TRADUÇÃO E INTERPRETAÇÃO DE \\ ISAÍAS 52.13-53.12
}

Versão Corrigida

\section{José Ribeiro Neto}

Dissertacão de Mestrado apresentada à Faculdade de Filosofia, Letras e Ciências Humanas da Universidade de São Paulo para a obtenção do título de Mestre em Letras Orientais.

Área de Concentração: Cultura Judaica

Orientador: Prof. Dr. Reginaldo Gomes de Araújo 
Nome: JOSÉ RIBEIRO NETO

Título: A influência da tradição na tradução e interpretação de Isaías 52.13-53.12

Dissertação de Mestrado apresentada à Faculdade de Filosofia, Letras e Ciências Humanas da Universidade de São Paulo para a obtenção do título de Mestre em Letras Orientais.

Aprovado em: / 2014

\section{BANCA EXAMINADORA}

\section{Prof. Dr. Reginaldo Gomes de Araújo}

Universidade de São Paulo

Julgamento: Assinatura:

\section{Prof. a Dr. ${ }^{a}$ Heloísa Pezza Cintrão}

Universidade de São Paulo

Julgamento: Assinatura:

Prof. Dr. Paulo de Sousa Oliveira

Seminário Teológico Batista Nacional Enéas Tognini

Julgamento: Assinatura: 


\title{
Dedicatória
}

Aos meus filhos:

\author{
Katarina Tavares Ribeiro \\ Israel Tavares Ribeiro \\ Esdras Tavares Ribeiro
}




\section{Agradecimentos}

Ao Professor Reginaldo Gomes de Araújo pela paciência e apoio em todos os momentos da pesquisa.

Ao Professor Moacir Amâncio pelas valiosas sugestões acadêmicas.

À Professora Heloísa Pezza Cintrão pelas sugestões a respeito das teorias de tradução e bibliografias referentes à área.

Ao Professor Paulo de Sousa Oliveira, amigo e companheiro em todos os momentos da minha vida acadêmica.

A todos os funcionários do DLO pela paciência e cordialidade.

À minha amada esposa Kátia Cristina Tavares Ribeiro pelo companherismo e compreensão em todos os momentos.

A todos meus alunos nos seminários teológicos onde ministro aulas que enriqueceram minhas pesquisas com perguntas e sugestões. 


\section{RESUMO}

Esta pesquisa procura analisar a influência da tradição na tradução e interpretação da perícope de Isaías 52.13-53.12. Inicialmente esta pesquisa discute a teoria de Eugene A. Nida, que tem sido a principal teoria nas discussões de tradução da Bíblia. Juntamente com a análise da teoria de Nida analisou-se também as principais discussões sobre tradução de outras vertentes acadêmicas e o uso das mesmas pelas principais tradições religiosas: judaicas, católicas e protestantes.

Por meio de estudo de casos específicos de tradução dessas diversas correntes religiosas analisou-se as influências teológicas na tradução de textos tais como Isaías 14.12 na tradição protestante, Isaías 9.5-6 na tradição judaica.

A pesquisa abordou o uso da paráfrase como meio utilizado pelas tradições religiosas para defender suas doutrinas em textos sensíveis da Bíblia Hebraica, bem como o poder da tradição interpretativa como interferência na produção de traduções alinhadas às posições teológicas das respectivas tradições.

A pesquisa procura delinear de forma breve, a história dos princípios de interpretação da tradição cristã e do judaísmo rabínico. As principais versões produzidas por essas tradições interpretativas: LXX, Vulgata, Targum e Peshitta foram expostas como produtos dessas tradições interpretativas e a perícope de Isaías 52.13-53.12 nessas antigas versões e no Novo Testamento, também como produtos de influência das diferentes tradições interpretativas do cristianismo e do judaísmo rabínico.

Por fim, o trabalho busca mostrar como o texto da perícope de Isaías 52.13-53.12 foi tratado nas fontes antigas do judaísmo rabínico e do cristianismo e os efeitos dessas tradições interpretativas em duas versões modernas da Bíblia Hebraica. A de linha judaica, conhecida como Bíblia Hebraica da Editora e Livraria Sêfer e a de linha protestante, denominada Nova Bíblia Viva.

Palavras-chave: Isaías 53 - Tradução - Tradição Interpretativa - Tradução da Bíblia Hebraica 


\begin{abstract}
This research analyzes the influence of tradition in the translation and interpretation of the pericope of Isaiah 52:13-53:12. Initially, this research discusses the theory of Eugene A. Nida, who has been the leading theory in discussions of Bible translation. Along with the analysis of the theory of Nida analyzed also the main discussions on translation of other academic aspects and their use by major religious traditions: Jewish, Catholic and Protestant.

Through case studies of specific translation of these various religious currents analyzed the theological influences in the translation of texts such as Isaiah 14:12 in the Protestant tradition, Isaiah 9:5-6 in Jewish tradition.

The study addressed the use of paraphrase as a means used by the religious traditions to defend their doctrines in sensitive texts of the Hebrew Bible, as well as the power of the interpretive tradition as interference in the production of translations aligned theological positions of the respective traditions.

The research seeks to outline briefly the history of the principles of interpretation of the Christian tradition and rabbinic Judaism. The main versions produced by these interpretive traditions: LXX, Vulgate, Targum and Peshitta were exposed to products of these interpretive traditions and the pericope of Isaiah 52:13-53:12 those old versions and the New Testament, as well as products of the influence of different interpretive traditions of Christianity and rabbinic Judaism.

Finally, the work seeks to show how the text of the pericope of Isaiah 52:13-53:12 was treated in the ancient sources of rabbinic Judaism and Christianity and the effects of these two interpretive traditions in modern versions of the Hebrew Bible. The line Jewish Hebrew Bible known as the Publisher and Bookstore Sefer and Protestant line called New Living Bible.
\end{abstract}

Keywords: Isaiah 53 - Translation - Interpretative Tradition - Translation of the Hebrew Bible 


\section{Tabelas}

TABELA 1

ALFABETO GREGO E TRANSLITERAÇ̃̃O UTILIZADA ${ }^{1}$

\begin{tabular}{|c|c|c|c|c|c|}
\hline $\begin{array}{c}\text { Forma } \\
\text { Maiúscula }\end{array}$ & $\begin{array}{c}\text { Forma } \\
\text { Minúscula }\end{array}$ & $\begin{array}{c}\text { Maiúscula } \\
\text { Manuscrita }\end{array}$ & Nome & Transliteração & Som \\
\hline $\mathrm{A}$ & $\alpha$ & $\Delta$ & alfa & $\mathrm{a}$ & $\mathrm{a}$ \\
\hline $\mathrm{B}$ & $\beta$ & B & beta & $\mathrm{b}$ & $\mathrm{b}$ \\
\hline$\Gamma$ & $\gamma$ & $\Gamma$ & gama & $\mathrm{g}$ & $\begin{array}{l}\text { g, sempre como em ga, gue, gui, go, } \\
\text { gu }\end{array}$ \\
\hline$\Delta$ & $\delta$ & $\Delta$ & delta & $\mathrm{d}$ & $\mathrm{d}$ \\
\hline $\mathrm{E}$ & $\epsilon$ & $\epsilon$ & épsilon & $\mathrm{e}$ & $\mathrm{e}$ \\
\hline $\mathrm{Z}$ & $\zeta$ & z & dzeta & $\mathrm{z}$ & $\mathrm{dz}$ \\
\hline $\mathrm{H}$ & $\eta$ & $\mathrm{H}$ & eta & $\hat{\mathrm{e}}$ & $\mathrm{e}$ \\
\hline$\Theta$ & $\theta$ & $\theta$ & theta & th & th, como em inglês think \\
\hline $\mathrm{I}$ & l & I & iota & $\mathrm{i}$ & $\mathrm{i}$ \\
\hline $\mathrm{K}$ & к & K & kapa & $\mathrm{k}$ & $\mathrm{k}$ \\
\hline$\Lambda$ & $\lambda$ & $\lambda$ & lambda & 1 & 1 \\
\hline $\mathrm{M}$ & $\mu$ & $M$ & mü & $\mathrm{m}$ & $\mathrm{m}$ \\
\hline $\mathrm{N}$ & $\nu$ & $\mathrm{N}$ & nü & $\mathrm{n}$ & $\mathrm{n}$ \\
\hline$\Xi$ & $\xi$ & $z$ & ksi & ks & ks \\
\hline $\mathrm{O}$ & 0 & $\mathrm{O}$ & ómicron & ó & ó \\
\hline$\Pi$ & $\pi$ & $\Pi$ & pi & $\mathrm{p}$ & $\mathrm{p}$ \\
\hline $\mathrm{P}$ & $\rho$ & $p$ & rô & $\mathrm{r}$ & $\mathrm{r}$ \\
\hline$\Sigma$ & $\sigma \varsigma$ & $\mathrm{C}$ & sigma & $\mathrm{s}$ & ss \\
\hline $\mathrm{T}$ & $\tau$ & $\mathrm{T}$ & tau & $\mathrm{t}$ & $\mathrm{t}$ \\
\hline Y & $\mathrm{u}$ & Y & üpsilon & $\mathrm{y}$ & ü, como em müller \\
\hline$\Phi$ & $\phi$ & $\phi$ & fi & $\mathrm{f}$ & $\mathrm{f}$ \\
\hline $\mathrm{X}$ & $\chi$ & $x$ & chi & $\underline{\mathrm{k}}$ & r bem forte, como o chet $(\Pi)$ hebraico \\
\hline$\Psi$ & $\psi$ & $\psi$ & psi & ps & ps \\
\hline$\Omega$ & $\omega$ & $\omega$ & ômega & $\hat{o}$ & ô \\
\hline
\end{tabular}


TABELA 2

ALFABETO HEBRAICO / ARAMAICO E TRANSLITERAÇÃO UTILIZADA ${ }^{2}$

\begin{tabular}{|c|c|c|c|c|c|c|}
\hline $\begin{array}{c}\text { Letra } \\
\text { Impressa }\end{array}$ & $\begin{array}{c}\text { Forma } \\
\text { Cursiva } \\
\end{array}$ & $\begin{array}{c}\text { Grafia de } \\
\text { Rashi }\end{array}$ & $\begin{array}{c}\text { Valor } \\
\text { Numérico } \\
\end{array}$ & Nome & Transliteração & Som \\
\hline 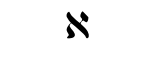 & IC & 6 & 1 & 'alef & , & sem som \\
\hline$\geq 2$ & 2 & 3 & 2 & beyt, veyt & $\mathrm{b}, \mathrm{v}$ & $\mathrm{b}, \mathrm{v}$ \\
\hline 2 & $\iota$ & 2 & 3 & guimel & $\mathrm{g}$ & $\begin{array}{c}\text { sempre como em ga, gue, gui, } \\
\text { go, gu }\end{array}$ \\
\hline 7 & 3 & 7 & 4 & dalet & $\mathrm{d}$ & $\mathrm{d}$ \\
\hline$\pi$ & ) & ה & 5 & hey & $\mathrm{h}$ & $\begin{array}{c}\mathrm{r} \text { fraco e sem som no final das } \\
\text { palavras }\end{array}$ \\
\hline 1 & 1 & 1 & 6 & waw & $\mathrm{w}$ & $\mathrm{v}$ \\
\hline$i$ & 3 & $i$ & 7 & zayn & z & z \\
\hline$\pi$ & $n$ & $D$ & 8 & ret & h & $\mathrm{r}$ bem forte \\
\hline$\varphi$ & U & D & 9 & thet & $\mathrm{t}$ & $\mathrm{t}$ \\
\hline , & , & , & 10 & yud & $\mathrm{y}$ & $\mathrm{i}$ \\
\hline 92 & $\supset \curvearrowright$ & 72 & 20 & $\begin{array}{c}\text { kaf, } \underset{\text { kaf, }}{\mathrm{kaf}} \\
\text { final }\end{array}$ & $\mathrm{k}, \underline{\mathrm{k}}, \underline{\mathrm{k}}$ & $\mathrm{k}, \mathrm{r}$ bem forte \\
\hline 3 & $\delta$ & 3 & 30 & lamed & 1 & 1, mesmo no final \\
\hline ם מ & $N D$ & 01 & 40 & $\begin{array}{c}\text { mem, mem } \\
\text { final }\end{array}$ & $\mathrm{m}$ & $\mathrm{m}$ \\
\hline 39 & J 1 & 32 & 50 & $\begin{array}{c}\text { nun, nun } \\
\text { final }\end{array}$ & $\mathrm{n}$ & $\mathrm{n}$ \\
\hline 0 & 0 & ס & 60 & samech & $\mathrm{s}$ & ss \\
\hline$\ddot{1}$ & $\gamma$ & ע & 70 & "ayn & c & sem som \\
\hline$\Xi \Xi=$ & o 8 & 90 & 80 & $\begin{array}{c}\text { pei, fei, fei } \\
\text { final }\end{array}$ & $p, f, f$ & $p, f, f$ \\
\hline$\ddot{3}$ & $3 y$ & $5 T$ & 90 & \begin{tabular}{|c|} 
tsad, tsad \\
final
\end{tabular} & ts & ts \\
\hline$P$ & P & $p$ & 100 & qof & $\mathrm{q}$ & $\mathrm{q}$ \\
\hline 7 & 7 & 7 & 200 & reish & $\mathrm{r}$ & $\begin{array}{c}\mathrm{r} \text { bem fraco como na palavra } \\
\text { hora }\end{array}$ \\
\hline ש & $e$ & E & 300 & shin, sin & śš & $\mathrm{x}$ ou ss \\
\hline$\pi$ & $\Omega$ & 8 & 400 & tav & $\mathrm{t}$ & $\mathrm{t}$ \\
\hline
\end{tabular}

2 Estamos utilizando uma transliteração simplificada de acordo com a pronúncia sefaradi 
TABELA 3

SINAIS VOCÁLICOS (OU DIACRÍTICOS) DO HEBRAICO / ARAMAICO BÍBLICO

\begin{tabular}{|c|c|c|c|}
\hline SINAL & $\begin{array}{c}\text { VOGAL QUE } \\
\text { REPRESENTA } \\
\end{array}$ & Transliteração & NOME \\
\hline$\square$ & $\mathrm{a}$ & $\mathrm{a}$ & Patach \\
\hline$\square$ & $\mathrm{a}$ & á & Chataf Patach \\
\hline$\square_{T}$ & a ou o & â ou ô & Qamats, ou Qamats Qatan \\
\hline$\square$ & e ou ei & e & Tsrey \\
\hline$\square$ & $\mathrm{e}$ & $\hat{\mathrm{e}}$ & Segol \\
\hline$\square$ & $\mathrm{e}$ & é & Chataf segol \\
\hline$\square$ & $\mathrm{i}$ & $\mathrm{i}$ & Chiriq \\
\hline 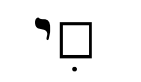 & $\mathrm{i}$ & $\hat{i}$ & Chiriq gadol \\
\hline$\square$ & $\mathrm{o}$ & o & Cholam \\
\hline$\dot{9}$ & $\mathrm{o}$ & ô & Cholam Wav \\
\hline$\square$ & o & ó & Chataf Qamets \\
\hline$\square$ & $\mathrm{u}$ & $\mathrm{u}$ & Qubutz \\
\hline $9 \square$ & $\mathrm{u}$ & $\hat{\mathrm{u}}$ & Shuruq \\
\hline$\square$ & $\begin{array}{l}\text { Resalta o som da } \\
\text { letra ou som de } e \\
\text { breve }^{3}\end{array}$ & e & Shevá \\
\hline
\end{tabular}

3 o shevá inaudível não será transcrito 
TABELA 4

ALFABETO SIRÍACO JACOBITA (OCIDENTAL) E TRANSLITERAÇÃO

UTILIZADA

\begin{tabular}{|c|c|c|c|c|c|c|c|}
\hline $\begin{array}{c}\text { Final ou } \\
\text { Medial }\end{array}$ & $\begin{array}{l}\text { Final } \\
\text { ligada }\end{array}$ & Medial & Inicial & No & & Transliteração & Som \\
\hline 1 & L & L & 1 & $9)^{8} l^{\circ}$ & Olaf & ‘ & sem som \\
\hline ح & ح & ـد & ح & حسـ & Bet & $\mathrm{b}, \mathrm{v}$ & $\mathrm{b}, \mathrm{v}$ \\
\hline$\otimes$ & 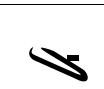 & 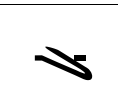 & $\rightarrow$ & W/8 & Gomal & $\mathrm{g}$ & $\begin{array}{c}\text { sempre como em } \\
\text { ga, gue, gui, go, gu }\end{array}$ \\
\hline ? & - & - & ? & $\Delta \Delta^{\prime}$ & Dolat & d & d \\
\hline$a$ & $a_{-}$ & $a$ & $a$ & na & Hei & $\mathrm{h}$ & $\begin{array}{c}\mathrm{r} \text { fraco e sem som } \\
\text { no final das } \\
\text { palavras }\end{array}$ \\
\hline 0 & a. & 0 & 0 & 00 & Uau & w & $\mathrm{v}$ \\
\hline $\mathbf{I}$ & $\vdash$ & $\vdash$ & J & امم & Zain & $\mathrm{z}$ & $\mathrm{z}$ \\
\hline מص & مس & مد & מـ & מה & Heth & h & $\mathrm{r}$ bem forte \\
\hline$t$ & A & 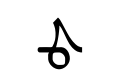 & $t$ & $\Delta \hat{\jmath}$ & Dteth & $\mathrm{t}$ & $\mathrm{t}$ \\
\hline n & n & ـ & ـ & هــ, & Iud & $\mathrm{y}$ & $\mathrm{i}$ \\
\hline$Y$ & $Y$ & 2 & ح & حُص & Cof & $\mathrm{k}, \underline{\mathrm{k}}, \underline{\mathrm{k}}$ & $\mathrm{k}, \mathrm{r}$ bem forte \\
\hline $\mathbb{M}$ & u. & $\lambda$ & $\Delta$ & | & Lomad & 1 & 1, mesmo no final \\
\hline p & pa & م & مـ & مسم & $\operatorname{Mim}$ & $\mathrm{m}$ & $\mathrm{m}$ \\
\hline 1 & $r$ & $\perp$ & 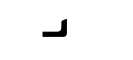 & به & Nun & $\mathrm{n}$ & $\mathrm{n}$ \\
\hline مـ & ص & 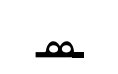 & هـ & مَحمده & Samcat & $\mathrm{s}$ & ss \\
\hline$u$ & a. & ــ & $\lambda$ & $\hat{\lambda}$ & $\mathrm{Ee}$ & “ & sem som \\
\hline 9 & a & 오 & 9 & فرا & $\mathrm{Pe}$ & $\mathrm{p}, \mathrm{f}, \mathrm{f}$ & $p, f, f$ \\
\hline$J$ & 5 & 5 & $J$ & ay & Dsode & ts & ts \\
\hline 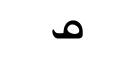 & مـ & مـ & مـ & مهد & Qof & $q$ & $\mathrm{q}$ \\
\hline ; & $:$ & $:$ & ; & زمـ & Rix & $\mathrm{r}$ & $\begin{array}{c}\mathrm{r} \text { bem fraco como } \\
\text { na palavra hora }\end{array}$ \\
\hline a & ـ & ـ & A & مـم & Xin & śs š & $\mathrm{x}$ ou ss \\
\hline$L$ & $\Delta$ & $\Delta$ & $L$ & oL & Tau & $\mathrm{t}$ & $\mathrm{t}$ \\
\hline
\end{tabular}


TABELA 5

ALFABETO SIRÍACO ESTRANGELA E TRANSLITERAÇÃO UTILIZADA

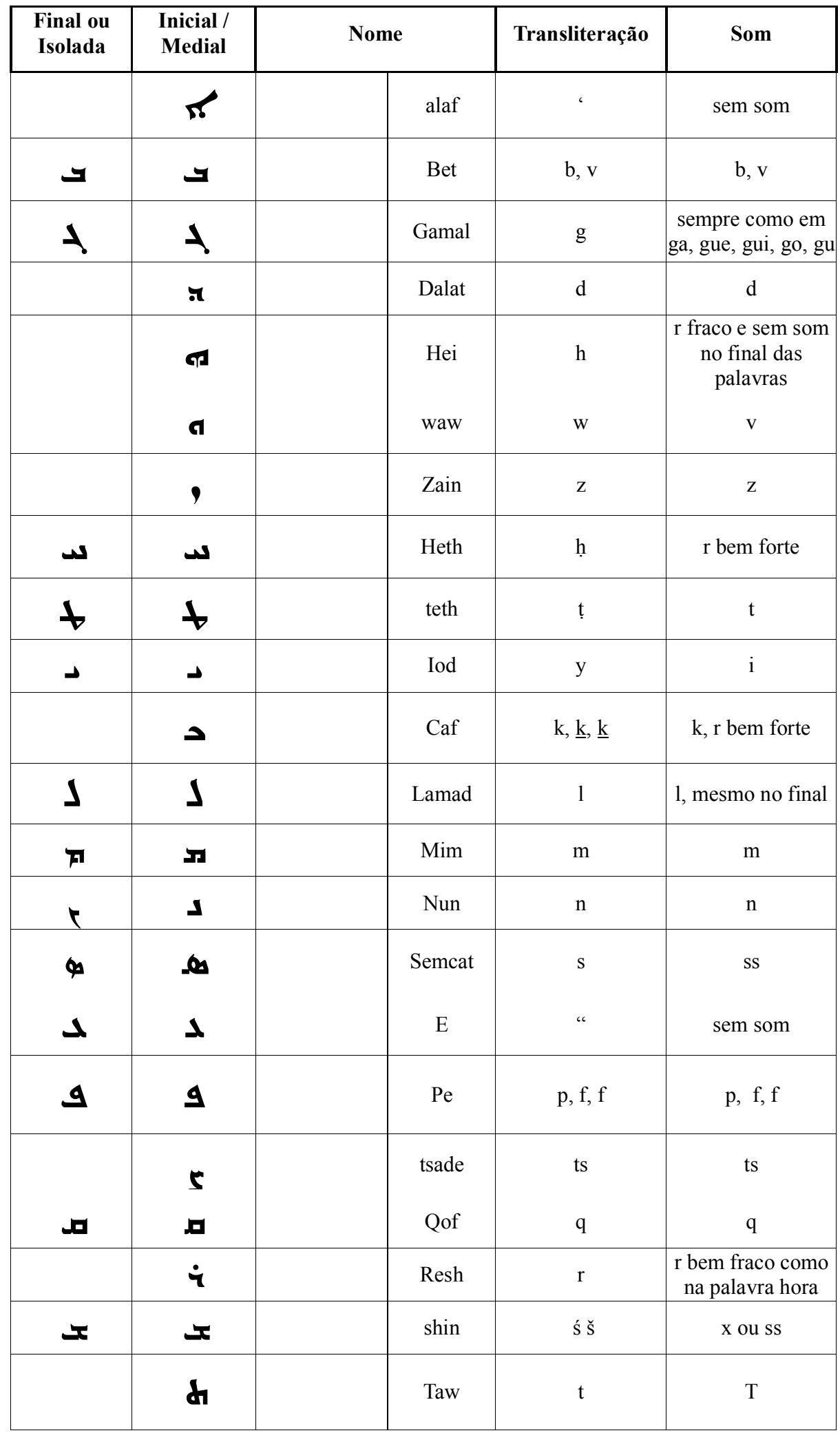


TABELA 6

ALFABETO ÁRABE

\begin{tabular}{|c|c|c|c|c|}
\hline Final & Medial & Inicial & Isolada & Transliteração \\
\hline$L$ & L & 1 & 1 & , \\
\hline$\varphi$ & $\div$ & ب & 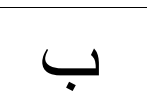 & $\mathrm{b}$ \\
\hline$\stackrel{ت}{1}$ & $\ddot{i}$ & ت & 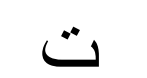 & $\mathrm{t}$ \\
\hline$\stackrel{+1}{1}$ & 辛 & ث & 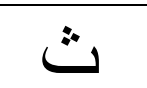 & $\underline{\mathrm{t}}$ \\
\hline ج & جे & $\rightarrow$ & ? & $\mathrm{j}$ \\
\hline$c$ & ح & $\rightarrow$ & $\tau$ & ha \\
\hline & $\dot{~ خ ~}$ & $\dot{\overrightarrow{\mid}}$ & $\dot{\tau}$ & $\mathrm{h}$ \\
\hline 1 & 1 & د د & د & d \\
\hline$i$ & $j$ & j & j & $\underline{\mathrm{d}}$ \\
\hline J & 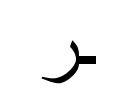 & $J$ & $J$ & $\mathrm{r}$ \\
\hline j- & $j$ & j & $j$ & $\mathrm{z}$ \\
\hline س山 & سـ & سـ & س & $\mathrm{s}$ \\
\hline ش & شـــ & شُــ & شز & $\check{s}$ \\
\hline ص & صـ & صد & ص & ș \\
\hline ضض & ضـ & ضـ & ض & ḍ \\
\hline b & b & ط & ط & $\mathrm{t}$ \\
\hline ظظ & ظظ & ظذ & ظظ & $\mathrm{z}$ \\
\hline$\varepsilon$ & $x$ & عـ & $\varepsilon$ & ‘ \\
\hline$\dot{c}$ & غ & غ & $\dot{\varepsilon}$ & $\overline{\mathrm{g}}$ \\
\hline
\end{tabular}




\begin{tabular}{|c|c|c|c|c|}
\hline ف & $\dot{\theta}$ & $\dot{\theta}$ & ف & $\mathrm{f}$ \\
\hline$\ddot{\theta}$ & $\ddot{\theta}$ & $\ddot{\theta}$ & $\ddot{\theta}$ & $\mathrm{q}$ \\
\hline 51 & $\leq$ & 5 & 5) & $\mathrm{k}$ \\
\hline $\mathcal{L}$ & $\perp$ & \rfloor & $J$ & 1 \\
\hline$\digamma$ & هـ & هـ & م & $\mathrm{m}$ \\
\hline$\dot{ن}$ & $i$ & $\dot{i}$ & $\dot{ن}$ & $\mathrm{n}$ \\
\hline$d$ & o & هـ & 0 & $\mathrm{~h}$ \\
\hline$g$ & $g$ & 9 & 9 & $\mathrm{w}$ \\
\hline ي & $\div$ & 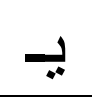 & ي & $\mathrm{y}$ \\
\hline
\end{tabular}


TABELA 7

ALFABETO PALEO-HEBRAICO / FENÍCIO / MOABITA / QUMRAN E TRANSLITERAÇÃO UTILIZADA

\begin{tabular}{|c|c|c|c|c|c|}
\hline $\begin{array}{c}\text { Letra } \\
\text { Fenícia / Moabita / } \\
\text { Paleo-Hebraico }\end{array}$ & Qunran & $\begin{array}{c}\text { Valor } \\
\text { Numérico }\end{array}$ & Nome & Transliteração & Som \\
\hline$\aleph$ & $N$ & 1 & 'alef & ‘ & sem som \\
\hline ב & ל & 2 & beyt, veyt & $\mathrm{b}, \mathrm{v}$ & $\mathrm{b}, \mathrm{v}$ \\
\hline$\lambda$ & $\lambda$ & 3 & guimel & $\mathrm{g}$ & $\begin{array}{c}\text { sempre como em ga, gue, } \\
\text { gui, go, gu }\end{array}$ \\
\hline 7 & 4 & 4 & dalet & d & $\mathrm{d}$ \\
\hline ה & $\pi$ & 5 & hey & $\mathrm{h}$ & $\begin{array}{c}\mathrm{r} \text { fraco e sem som no final } \\
\text { das palavras }\end{array}$ \\
\hline 1 & 1 & 6 & waw & $\mathrm{w}$ & $\mathrm{v}$ \\
\hline T & 1 & 7 & zayn & $\mathrm{z}$ & $\mathrm{z}$ \\
\hline$\pi$ & $\pi$ & 8 & ret & $\underline{r}$ & $\mathrm{r}$ bem forte \\
\hline 0 & ט & 9 & thet & $\mathrm{t}$ & $\mathrm{t}$ \\
\hline , & 4 & 10 & yud & $\mathrm{y}$ & $\mathrm{i}$ \\
\hline 7 & $4 \quad 4$ & 20 & $\begin{array}{l}\text { kaf, } \underset{\text { kaf, }}{\text { kaf }} \\
\text { final }\end{array}$ & $\mathrm{k}, \underline{\mathrm{k}}, \underline{\mathrm{k}}$ & $\mathrm{k}, \mathrm{r}$ bem forte \\
\hline ל & b & 30 & lamed & 1 & 1 , mesmo no final \\
\hline a & $y$ & 40 & $\begin{array}{l}\text { mem, mem } \\
\text { final }\end{array}$ & $\mathrm{m}$ & $\mathrm{m}$ \\
\hline 1 & J & 50 & nun, nun final & $\mathrm{n}$ & $\mathrm{n}$ \\
\hline ס & D & 60 & samech & $\mathrm{s}$ & ss \\
\hline ע & $y$ & 70 & "ayn & “ & sem som \\
\hline ๆ & 29 & 80 & $\begin{array}{l}\text { pei, fei, fei } \\
\text { final }\end{array}$ & $\mathrm{p}, \mathrm{f}, \mathrm{f}$ & $p, f, f$ \\
\hline$\gamma$ & $Y \quad Y$ & 90 & tsad, tsad final & ts & ts \\
\hline P & $p$ & 100 & qof & $q$ & $\mathrm{q}$ \\
\hline ר & ר & 200 & reish & $\mathrm{r}$ & $\begin{array}{c}\mathrm{r} \text { bem fraco como na } \\
\text { palavra hora }\end{array}$ \\
\hline 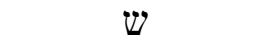 & $U$ & 300 & shin, sin & $\dot{s}, \underline{\mathrm{S}}$ & $\mathrm{x}$ ou ss \\
\hline$ת$ & $\pi$ & 400 & tav & $\underline{\mathrm{t}}$ & $\mathrm{t}$ \\
\hline
\end{tabular}


TABELA 8

\section{ALFABETO UGARÍTICO}

\begin{tabular}{|c|c|c|}
\hline SÍMBOLO & $\begin{array}{c}\text { SÍMBOLO } \\
\text { ALTERNATIVO }\end{array}$ & TRANSLITERAÇÃ̃O \\
\hline 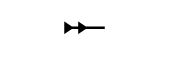 & 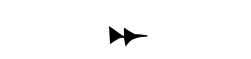 & 'a \\
\hline$\risingdotseq$ & $E$ & 'i \\
\hline III & $\sqrt{n}$ & 'u \\
\hline II & $A$ & $\mathrm{~b}$ \\
\hline T & $r$ & $\mathrm{~g}$ \\
\hline III & III & $\mathrm{d}$ \\
\hline$V$ & $v$ & $\underline{\mathrm{d}}$ \\
\hline$\equiv$ & $E$ & $\mathrm{~h}$ \\
\hline br & Ew & $\mathrm{w}$ \\
\hline 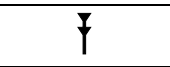 & 7 & $\mathrm{z}$ \\
\hline H & w & h \\
\hline$\$$ & 7 & $\mathrm{~h}$ \\
\hline K & $\pi$ & $t$ \\
\hline$\equiv 1$ & $x$ & $\mathrm{z}$ \\
\hline H & $\frac{\pi}{n}$ & $y$ \\
\hline$\square$ & $\Delta$ & $\mathrm{k}$ \\
\hline III & $m$ & 1 \\
\hline 7 & $H$ & $\mathrm{~m}$ \\
\hline$m$ & $m$ & $\mathrm{n}$ \\
\hline$Y$ & 7 & $\mathrm{~s}$ \\
\hline 汗 & 告 & $\grave{s}$ \\
\hline 4 & 4 & ‘ \\
\hline$\checkmark$ & 4 & $\mathrm{~g}^{\prime}$ \\
\hline$\leftleftarrows$ & $E$ & $\mathrm{p}$ \\
\hline II & $\pi$ & ș \\
\hline 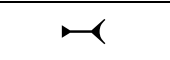 & $M$ & $\mathrm{q}$ \\
\hline 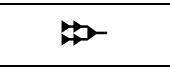 & $a$ & $\mathrm{r}$ \\
\hline$\langle/ V$ & $\downarrow$ & $\check{s}$ \\
\hline 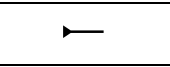 & 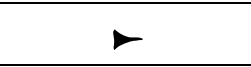 & $\mathrm{t}$ \\
\hline$X$ & $\alpha$ & $\underline{t}$ \\
\hline T & & $\begin{array}{c}\text { Símbolo de divisão de } \\
\text { palavra }\end{array}$ \\
\hline
\end{tabular}




\section{ABREVIATURAS}

ACF - Almeida Corrigida Fiel

ARA - Almeida Revista e Atualizada

ARC - Almeida Revista e Corrigida

AT - Antigo Testamento

BH - Bíblia Hebraica

BHS - Bíblia Hebraica Sttutgartensia

BJ - Bíblia de Jerusalém

BLH - Bíblia na Lingaguem de Hoje

CNBB - Conferência Nacional dos Bispos do Brasil

DITAT - Dicionário Internacional de Teologia do Antigo Testamento

JPS - Jewish Publication Society (1917)

KJV - King James Version

LXX - Versão Grega do Antigo Testamento, conhecida como Septuaginta

NET Bible - New English Translation

NIV - New International Version

NVI - Nova Versão Internacional

NT - Novo Testamento

NTLH - Nova Tradução na Linguagem de Hoje

PES - Versão Síria da Bíblia conhecida como Peshita

SBB - Sociedade Bíblica do Brasil

SBTB - Sociedade Bíblica Trinitariana do Brasil

TAR - Targum, traduções da Bíblia Hebraica para o aramaico

TEV - Today English Version

TNM - Tradução do Novo Mundo das Escrituras Sagradas

$\mathbf{U B S}^{4}$ - O Novo Testamento Grego 4. Edição United Bible Society

VUL - Versão Latina da Bíblia conhecida como Vulgata 


\section{SUMÁRIO}

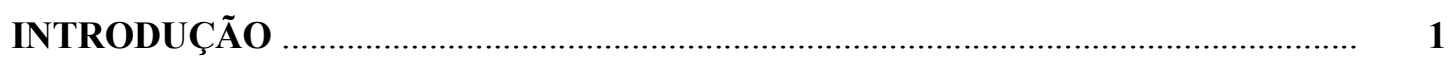

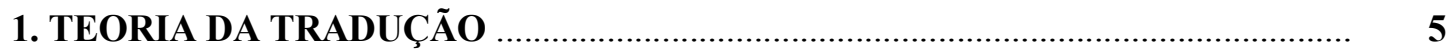

1.1 Teoria da equivalência ………….............................................................................. 6

1.1.1 Equivalência formal (Correspondência Formal) ……………………………….........

1.1.2 Equivalência dinâmica (Equivalência Funcional) .......................................................... 11

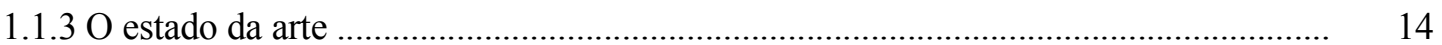

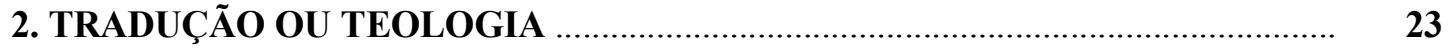

2.1 A interferência teológica cristã na tradução de Isaías 14.12 ....................................... 24

2.1.1 A Primeiras interpretações do texto de Is 14.12 ........................................................... 24

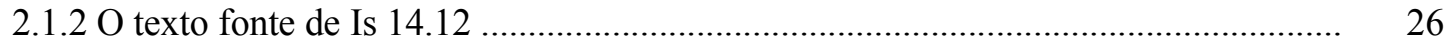

2.1.3 A ocorrência da palavra lucifer na Vulgata Latina .................................................... 27

2.1.4 Definição do termo latino ........................................................................................ 29

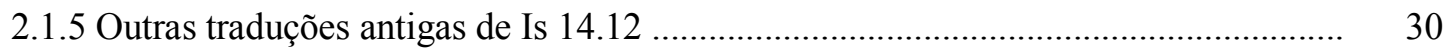

2.1.5.1 Targum de Jônatas ............................................................................................ $\quad 30$

2.1.5.2 Versão Grega (LXX) ……………………….................................................... 30

2.1.6 Outras traduções do texto nas tradições protestantes, católicas e judaicas .................. 31

2.2 Interferência teológica rabínica na tradução de Is 9.5-6 …………………………........... 32

2.3 Interferência teológica na Tradução do Novo Mundo das Escrituras Sagradas (Testemunhas de Jeová) ……………………………................................................ 35

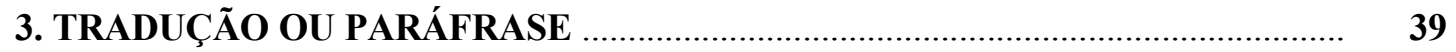

4. TRADUÇÃO OU TRADIÇÃO INTERPRETATIVA ................................................. 50

4.1 O poder da tradição ............................................................................................... 52

4.2 A canonização de versões autorizadas pela tradição ......................................................... 54

4.3 Princípios de interpretação cristã ............................................................................ 55 
4.4 Princípios de interpretação rabínica ......................................................................... 73

5. HISTÓRIA DAS PRINCIPAIS TRADUÇÕES (VERSÕES) ANTIGAS DA BH.... 86

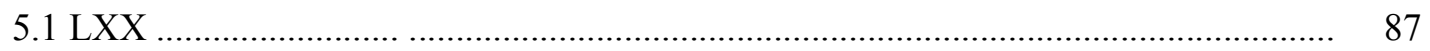

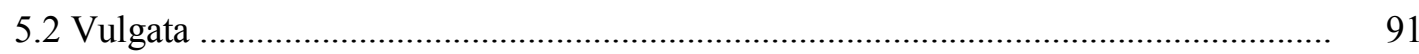

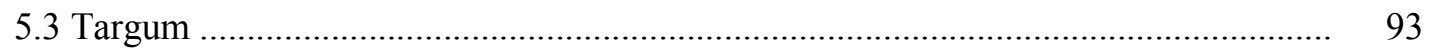

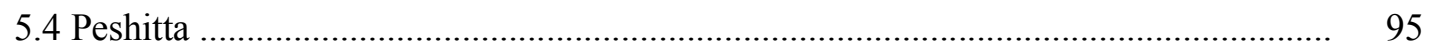

6. TRADUÇÕES ANTIGAS DO TEXTO DE IS 52.13-53.12 ...................................... 97

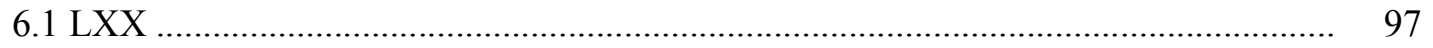

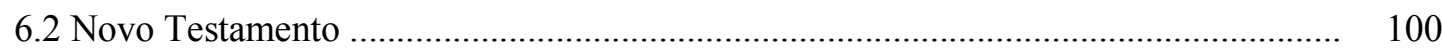

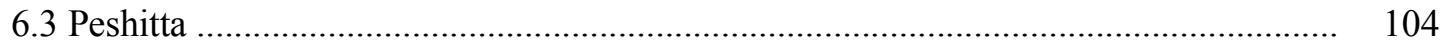

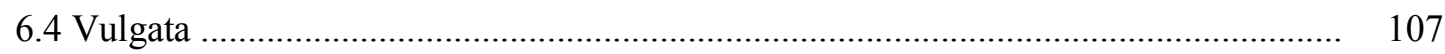

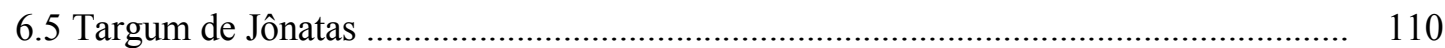

7. O TEXTO DE IS 52.13-53.12 E A TRADIÇÃO INTERPRETATIVA NAS

FONTES JUDAICO-CRISTÃS ANTIGAS ................................................................ 116

8. TRADUÇÕES-INTERPRETAÇÕES MODERNAS DO TEXTO DE

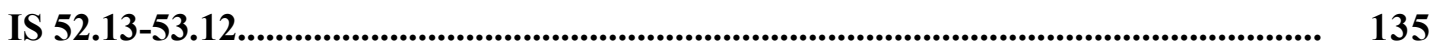

8.1 Tradução judaica da Editora e Livraria Sêfer ............................................................. 135

8.2 Tradução cristã protestante ………………………................................................ 138

CONSIDERAÇÕES FINAIS _.................................................................................. 141

APÊNDICE A: TRADUÇÃO INTERLINEAR LITERAL DE IS 52.13-53.12.............. 146

APÊNDICE B: Hiney Yaskyl 'Avdy de Nachmânides ................................................................. 149

ANEXO A: MIDRASH DE RUTH RABA CONTENDO A INTERPRETAÇÃO DE

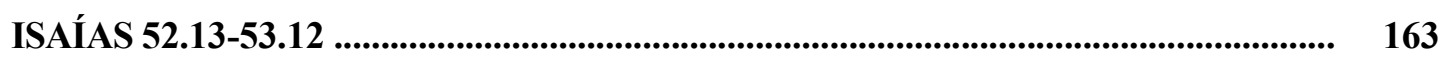

ANEXO B: PÁGINA DO MIKRAOTH GEDOLOTH CONTENDO O TEXTO E AS

INTERPRETAÇÕES DE IS 52.13-53.12........................................................................... 166

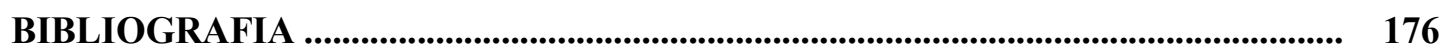




\section{Introdução}

O contato que temos com o ambiente cultural estrangeiro vem a nós, primeiramente, por meio de traduções, ou seja, a nossa leitura e interpretação de um mundo estranho ao nosso chega-nos em segunda mão. Se já há dificuldade de uma leitura de primeira mão, pois a nossa cosmovisão também interfere na leitura que fazemos dos textos, maior dificuldade nos traz uma leitura que passa pelo crivo do tradutor ou tradutores das obras estrangeiras a que temos acesso.

Nessa complexidade de vozes e mentalidades, que são os filtros pelos quais os textos passam para chegar até o nosso conhecimento, as traduções constituem elemento essencial de estudo para entendermos esses processos pelos quais as obras literárias primeiramente sofrem antes de chegar ao público leitor.

A questão, porém, que é preciso focar, dentre tantas outras, é o fato de haver muitas teorias de tradução que são fios condutores pelos quais o tradutor é condicionado a produzir a sua obra, partindo de uma língua fonte até chegar à língua alvo, na qual a tradução é o produto final de seu trabalho.

A tradução como campo de estudo acadêmico é uma ciência nova. Embora desde a antiguidade já se fizessem reflexões sobre princípios de tradução, o estudo acadêmico da disciplina como campo separado é recente.

Como em todo campo de estudo científico, necessário foi refletir e teorizar sobre os processos e princípios subjacentes à tradução; nessa teorização, muitas abordagens foram e continuam feitas sobre os princípios e processos de tradução. Não se pode negar, contudo, que, tanto no passado como no presente, a tradução da Bíblia tem ocupado lugar de importância nas discussões sobre tradução, tanto por ser o texto mais traduzido em toda a história da humanidade, como pelo fato de ser texto sensível nas mais diversas tradições religiosas e, principalmente, nas tradições cristãs e judaicas.

O protestantismo, mais do que qualquer outra tradição religiosa, produziu o maior número de traduções da Bíblia nas mais diferentes línguas conhecidas. Fundador de Sociedades Bíblicas e com propósitos missionários, produziu as traduções da Bíblia a fim de fazer proselitismo religioso. Essa profusão de versões protestantes resultou num impacto em outras tradições religiosas, tais como as tradições católicas e também judaicas.

Versões tradicionais da Bíblia protestante começaram a ser criticadas ou defendidas

pelas mais diversas correntes teóricas sobre tradução, tanto, internamente, no meio 
protestante, quanto, externamente, no meio acadêmico ou no meio religioso por tradições que se opunham ao protestantismo e suas versões da Bíblia.

A partir dos trabalhos de Eugene A. Nida (1914-2011), as traduções consagradas da Bíblia começaram a ser vistas como ultrapassadas ou como arcaicas demais, sendo necessária a produção de novas versões, mais atuais, mais alinhadas com as novas teorias da crítica textual e com as teorias linguísticas e de tradução mais aceitas pelo mundo acadêmico. Em inglês, a versão mais questionada foi a King James (ou versão do Rei Tiago) e em português, como resultado direto do questionamento da King James Version (KJV, 1611), as versões baseadas na Tradução de João Ferreira de Almeida, a Almeida Corrigida, Almeida Corrigida e Atualizada e Almeida Corrigida Fiel, com várias edições desde o século XVIII d.C.

No debate pela produção de novas versões da Bíblia podem ser destacados os trabalhos de Eugene A. Nida, com sua teoria de tradução baseada no paradigma da equivalência. Por causa de sua influência no campo da tradução no meio acadêmico e sua importância dentro do campo de tradução da Bíblia, é que o presente trabalho norteará a sua pesquisa com base nas teorias de Nida, mas relacionando as teorias desse autor com outras teorias no campo da tradução e da linguística.

Dentre os textos que fazem parte do debate sobre a tradução e interpretação da Bíblia Hebraica está o texto de Isaías 52.13-53.12. De acordo com a cosmovisão cristã, o texto refere-se a Jesus e a seu sofrimento na cruz do calvário. Do lado da maioria da cosmovisão rabínica, o texto diz respeito a Israel e seu sofrimento.

O objetivo da nossa pesquisa é analisar as fontes judaicas e cristãs para verificar, se, e como as duas cosmovisões diferentes, influenciaram a tradução e a interpretação do texto hebraico de Isaías 52.13-53.12, observando assim, se a tradição interpretativa pode interferir no trabalho de tradução de um texto quando este é carregado de influências e debates teológicos.

A justificativa do trabalho está no fato do ressurgimento do debate judaico-cristão nas muitas mídias da internet e das novas versões da Bíblia, que procuram novas propostas de tradução, contudo, em muitas dessas novas versões, ao invés da tentativa de transpor para a língua destino o texto fonte, fazem paráfrases interpretativas do texto original de acordo com as suas próprias cosmovisões.

A proposta de nossa pesquisa é expor como a tradição pode interferir no resultado de uma tradução. Para isso, utilizaremos de pesquisa no texto fonte estabelecido, conhecido como texto massorético, abordando-o do ponto de vista tanto diacrônico quanto sincrônico, e nos valeremos das principais gramáticas de língua hebraica e estudos semíticos comparados, 
para uma proposta de tradução do texto de Is 52.13-53.12 que chegue mais próxima ao sentido do texto fonte.

Utilizaremos também a linguística, quando a mesma puder ser inferida nas teorias de tradução para suporte do nosso arcabouço teórico, aplicando tais teorias na produção de uma tradução, e como ferramenta de comparação com versões que trazem uma forte influência da tradição em seus resultados de tradução.

Será necessária também a comparação das várias propostas de tradução com as versões antigas mais clássicas tal como a LXX, Vulgata, NT, Peshitta, Targum e de comentaristas rabínicos e cristãos, que durante a história deram uma proposta de tradução e interpretação do texto e, como essa carga teológico-interpretativa, contribuiu ou interferiu na compreensão e tradução do texto.

Será feita uma análise da versão de Is 52.13-53.12 da tradução da Bíblia Hebraica feita pela Editora e Livraria Sêfer, por se tratar de uma versão que se dirige ao público judeu e por se tratar de uma versão que demonstra como a tradição pode interferir em uma tradução de modo a manter o establishment interpretativo do tema messiânico.

A pesquisa se dará por meio de análise de bibliografias específicas que analisem criticamente as versões antigas que trabalham o texto de Is 52.13-53.12. Para isso será necessário analisar os princípios de tradução utilizados na antiguidade em versões antigas, tais como as principais versões conhecidas: LXX, Vulgata, Targumim, nos Midraxes e em Rashi.

A pesquisa nessas versões necessitará ainda de uma análise da crítica textual, de modo a tratar do problema de variantes textuais nas versões antigas estudadas, procurando assim verificar se houve influência da tradição nessas versões que modificaram o texto hebraico, bem como se houve modificações no próprio texto tradicional por influência teológica.

No primeiro capítulo, será feita uma breve análise histórico-linguística da teoria de tradução de Nida, a interferência nas novas traduções protestantes, e como essa teoria interferiu no debate entre as tradições religiosas cristãs e judaicas, assim como o efeito da teoria na interferência da tradição na tradução da Bíblia Hebraica. Também serão discutidos nos subtópicos desse capítulo o estado da arte da teoria de tradução, relacionando esse estado com a interferência na tradução da Bíblia Hebraica.

O segundo capítulo analisará a interferência da tradição teológica na tradução da Bíblia Hebraica, nesse ínterim, será feito um estudo de caso da tradução do texto de Is 14.12, e de como o texto sofreu interferência da tradição interpretativa cristã, interferindo em tradições antigas da Bíblia Hebraica e até mesmo nos léxicos do hebraico bíblico. Nesse mesmo capítulo, será feito um outro estudo de caso no texto de Is 9.6-7(9.5-6) e como a 
tradição interpretativa judaica interferiu na produção desse texto na versão da Bíblia Hebraica da Livraria Sêfer em português. Por último, nesse capítulo, será feito um último estudo de caso sobre a interferência da tradição teológica no grupo religioso conhecido como Testemunhas de Jeová em sua versão Tradução do Novo Mundo das Escrituras Sagradas no texto de Gn 1.2. Os estudos de caso serão feitos em comparação com versões modernas da Bíblia Hebraica, assim como com versões antigas dos mesmos textos.

O capítulo terceiro abordará o conceito de paráfrase e o conceito da mesma como princípio norteador de algumas traduções, implícita ou explicitamente. Para análise será utilizado, como estudo de caso, o texto do Salmo 23 em duas versões em português, a NTLH (Nova Tradução na Linguagem de Hoje e a Nova Bíblia Viva, em comparação com o texto fonte da Bíblia Hebraica, indicando quais elementos linguísticos foram parafraseados.

O capítulo quarto é uma análise da interferência da tradição interpretativa na tradução da Bíblia Hebraica. Será analisado o poder da tradição em nortear a cosmovisão do tradutor na produção das versões da Bíblia, a canonização de versões autorizadas e referendadas pelas tradições interpretativas. Como elemento importante para entendimento da interferência da tradição interpretativa na tradução da Bíblia, serão analisados, ainda nesse capítulo, os princípios de interpretação protestantes, católicos e judaicos e como esses princípios geraram essa interferência na produção das versões consagradas por essas tradições religiosas.

O capítulo quinto fará um breve histórico das principais versões antigas da Bíblia Hebraica com o propósito de situar, diacronicamente, a problemática da tradição na tradução da Bíblia Hebraica, e de como a tradição interpretativa interferiu na produção dessas versões consagradas nas mais diversas correntes religiosas.

O sexto capítulo analisa como as versões LXX, o Novo Testamento a Vulgata e os Targumim traduziram a perícope de Is 52.13-53.12.

O sétimo capítulo analisará a tradição de interpretação da perícope ${ }^{1}$ em fontes judaicas antigas: Qumran, nos midrashim, no Talmude, Agadá, nos debates da Idade Média e na Qabalah.

O capítulo nono analisará duas traduções modernas da perícope, uma da Editora e Livraria Sêfer, denominada de Bíblia Hebraica, representando a tradição judaica de interpretação e outra da Editora Mundo Cristão, conhecida como Nova Bíblia Viva, representando a interpretação cristã protestante da perícope, verificando como as tradições interpretativas dessas duas religiões interferiram na tradução da Bíblia Hebraica.

$1 \quad$ Entende-se por perícope um parágrafo ou unidade literária de sentido 


\section{Teoria da Tradução}

Grandes debates em relação às teorias de tradução aconteceram e continuam acontecendo no campo de tradução da Bíblia. Por se tratar de um texto considerado sagrado e gerador de comportamento tanto moral como religioso, e por ser o formador da doutrina e prática das mais diversas religiões e credos existentes, a tradução da Bíblia permanece como faísca inicial dos mais acalorados debates entre as diversas expressões religiosas, pois depende da "correta" tradução das Escrituras Sagradas a doutrina e a prática desses segmentos sociais.

Esse debate não teve só influência na formação da doutrina dos diferentes sistemas de fé como também delineou as principais discussões a respeito dos princípios e teorias de tradução. Levando em conta que o livro mais traduzido na história é a Bíblia ${ }^{2}$ e permanece palco de debate de importantes teorias de tradução no mundo ocidental. ${ }^{3}$

Será importante para o nosso trabalho, portanto, entender as teorias de tradução mais utilizadas dentro do campo de tradução da Bíblia, a fim de verificar o uso dessas teorias ou o abandono das mesmas na tradução e interpretação do texto de Isaías 52.13-53.12. Porém, devido à multiplicidade de teorias de tradução, procuraremos focar nosso estudo na teoria das equivalências desenvolvida por Nida $(1982 ; 1986)^{4}$, posto que esta é a teoria de tradução utilizada em importantes versões da Bíblia Hebraica, tanto em português como em Inglês. ${ }^{5}$

2 Referimo-nos aqui tanto à Bíblia Judaica, chamada Tanak (ת), à Bíblia Católica com os chamados livros apócrifos ou deuterocanônicos, quanto à Bíblia Protestante, igual à Judaica nos primeiros 39 livros (exceto no arranjo dos livros) e diferente da mesma por conter o que é conhecido como Novo Testamento. Embora seja fato que dentre essas três tradições de Escrituras Sagradas a Bíblia Protestante seja a que possui o maior número de traduções já feitas na história, quer em porções ou de forma completa. Somente a Sociedade Bíblica do Brasil em sua revista A Bíblia no Brasil (n. 231 Abril a Junho de 2011 - Ano 63, p. 10-15) comemora a impressão de 100 milhões de Bíblias em 16 anos de existência, essa organização enviou 23 milhões de Bíblias para 105 diferentes países (A Bíblia No Brasil, n. 231 Abril a Junho de 2011 - Ano 63, p. 13).

O principal teórico no campo de tradução da Bíblia, e que é amplamente citado, é Eugene A. Nida (19142011) e o seu trabalho de reflexão sobre teorias de tradução se dá no âmbito da Bíblia, sua obra principal: NIDA, Eugene A.; TABER, Charles R. The Theory and Pratice of Translation. Leiden: United Bible Societies, 1982, será discutida nos tópicos seguintes como principal fonte utilizada nas discussões atuais sobre equivalência $\mathrm{e}$ tradução de textos bíblicos.

4 Nida (2001, p. 1-11) faz uma breve análise do que é tradução, também discute os três maiores tipos de teorias de tradução definindo-as da seguinte forma: 1. Teorias baseadas em perspectivas filológicas; 2 . Teorias baseadas em perspectivas linguísticas e 3. Teorias baseadas em sociosemiótica, (NIDA, 2001, p. 107-114). Em Nida (1986, p. 182) ou autor havia dividido as teorias em quatro: “...filológica, linguística, comunicativa (teoria da comunicação) e sociosemiótica.

${ }^{5}$ Em português: NTLH, A Bíblia Viva e a NVI (em parte traduzida por equivalência formal e em parte por equivalência dinâmica), em inglês: New Jerusalem Bible, New English Bible, Revised English Bible, Good News Bible, Complete Jewish Bible, New Living Translation, God's Word Translation, Contemporary English 


\subsection{A teoria da equivalência}

Adotando o paradigma linguístico de Chomsky e aplicando-o a tradução da Bíblia, Nida passou a desenvolver a teoria das equivalências, questionando as versões mais clássicas da Bíblia feitas em língua inglesa e propondo novas versões dentro da nova perspectiva. Como veremos, tornou-se o porta-voz das novas versões bíblicas em todo o mundo, fundamentadas na teoria da equivalência dinâmica ou funcional, inaugurando uma nova perspectiva para a tradução do texto sagrado, principalmente nos meios protestantes, mas sem deixar de influir indiretamente em outras tradições religiosas. Desenvolvida por Eugene A. Nida (1914-2011), a teoria da equivalência foi a que mais causou impactos nas teorias de tradução da Bíblia, de modo que esses impactos perduram até hoje, principalmente nos círculos religiosos protestantes. Pym (2010, p. 6) informa que "O termo 'equivalência', em várias línguas europeias, se tornou uma das características das teorias de tradução do Ocidente na segunda metade do século XX. Seu apogeu se deu entre os anos de 1960 e 1970, particularmente dentro da estrutura da linguística estruturalista."

A teoria, é, nesses círculos, odiada por uns ${ }^{6}$ e amada por outros. É usada como teoria orientadora de projetos de tradução da Bíblia das Sociedades Bíblicas do Brasil (SBB) e discutida também em outros projetos de tradução da Bíblia para o mundo protestante, como, por exemplo, o projeto da Nova Versão Internacional (NVI), executado no Brasil pela Editora Vida, editora voltada à publicação de materiais de cunho teológico-devocional para o público protestante brasileiro.

Em vários congressos organizados pela SBB e nos chamados Fórum de Ciências Bíblicas ou Seminário de Ciências Bíblicas, quando o assunto é tradução bíblica, a teoria das equivalências proposta por Nida é discutida amplamente. Em um desses fóruns (FÓRUM DE CIÊNCIAS BÍBLICAS, VII, 18 a 19 de Agosto de 2011, Barueri, SP. São Paulo: SBB) um dos principais temas em discussão foi justamente a exaltação da teoria de Nida em detrimento às outras teorias, ou a basicamente a chamada "antiga forma de traduzir" denominada por

Version. Esta multiplicidade de versões que usam a metodologia de Nida está no fato do próprio Nida ter sido o Secretário Executivo da American Bible Society's Translations Department, foi também o fundador da Wycliffe Bible Translators atuou em parceria com o Summer Institute of Linguistics. A atuação e influência de Nida nas traduções protestantes da Bíblia é imensa, ele é, por exemplo, o organizador do texto grego do NT, texto crítico base para tradutores do NT em todo o mundo, no prefácio desse texto Nida é citado no prefácio com grandes honras (vide O NOVO TESTAMENTO GREGO. 4. Ed., 2009 (UBS ${ }^{4}$ ), p. v).

${ }^{6}$ Para uma crítica ferrenha às teorias de Nida dentro do protestantismo, ver < http://solascripturatt.org/Bibliologia-Traducoes/VersoesModernasDaBiblia-Cloud-Livro.htm> acesso em: 17 jun. 2013. 
"equivalência formal". Esses fóruns pretendem divulgar a principal tradução das Sociedades Bíblicas do Brasil atualmente denominada Nova Tradução na Linguagem de Hoje (NTLH), que segundo afirmação da SBB é uma tradução "melhor" do que as mais tradicionais no meio protestante, por exemplo, a Almeida Revista e Corrigida (ARC), Almeida Revista e Atualizada (ARA), ambas também publicadas pela SBB e a Almeida Corrigida Fiel (ACF), publicada pela Sociedade Bíblica Trinitariana. Em 2008, a SBB publicou algumas palestras desses fóruns no livro "Manual do Seminário de Ciências Bíblicas", nesse manual, há um artigo escrito por Zimmer e Teixeira intitulado: Traduções da Bíblia: história, princípios e influência", nesse artigo (p. 60-66), os autores expõem a teoria das equivalências de Nida e defendem o princípio da "equivalência funcional" que também chamam de "princípio de equivalência comunicacional (MANUAL DO SEMINÁRIO DE CIÊNCIAS BÍBLICAS, 2008, p. 60-66).

Sayão (2001) elabora uma publicação exclusiva para defender a NVI e os princípios de tradução subjacentes à mesma, contrapondo essa versão e seus princípios de tradução com as versões mais populares da Bíblia e os antigos princípios de tradução nelas subjacentes. ${ }^{7}$

Por um lado, no meio protestante, há uma tradição recebida das principais versões utilizadas (ARC, ARA, ACF), que se tornaram uma espécie de Textus Receptus ${ }^{8}$ protestante, e em alguns grupos, rejeita-se qualquer outra tradução feita que divirja dessas versões. De outro lado, estão aqueles tradutores protestantes mais alinhados com o meio acadêmico, chamado secular, ou profano, que elegeram, principalmente as teorias de Eugene Nida ${ }^{9}$ como teoria orientadora das novas versões ${ }^{10}$ e igualmente acabam criando outra tradição de traduções, um outro Textus Receptus, mais modernizado e alinhado com as mais novas teorias de tradução.

\footnotetext{
7 A publicação tem o sugestivo título: NVI: A Bíblia do século 21, as principais versões expostas na comparação são as já citadas ARC, ARA e ACF, principalmente no Capítulo V (p. 61-75), que também tem o sugestivo título: Beleza, clareza e dignidade: marcas da NVI.

8 Dá-se o nome de Textus Receptus aos antigos manuscritos bíblicos estabelecidos como fonte original da qual as outras traduções procedem, no caso da Tanak, o Textus Receptus é o Texto Massorético estabelecido pela tradição da família de massoretas Ben Asher (ver Francisco, 2008, p. 283-284), em se tratando do Novo Testamento o Textus Receptus é o texto que tem esse nome mesmo, estabelecido por Erasmo de Roterdam no século XVI.

9 Em Sayão (2001, p. 29), lemos: “(...) Esse aprofundamento científico também encontrou representantes entre estudiosos cristãos e evangélicos, que contribuíram para uma compreensão mais aprofundada do grego e do hebraico bíblico. Alguns nomes merecem destaque especial: Eugene Nida, James Barr, Moisés Silva, K. L. Pike e Johannes Louw."

10 Não é de hoje essa defesa da teoria de Nida da equivalência dinâmica, já Werner Kaschel (1979, in: $2 .^{\circ}$ Congresso Nacional da Bíblia: Teses. Transformações gramaticais no processo da tradução dinâmica da Bíblia com vistas ao livro de Provérbios, p. 49-66), expõe as vantagens da equivalência dinâmica em detrimento da chamada equivalência formal (termos dos primeiros trabalhos de Nida). Novamente, a comparação é feita entre a então insurgente BLH (Bíblia na Linguagem de Hoje) e as versões mais populares amplamente utilizadas no mundo protestante, definidas pelo autor como RC (Revista e Corrigida), RAB (Revista e Atualizada no Brasil) e a que ele chama de RIB (Revista pela Imprensa Bíblica Brasileira).
} 
A tradição judaica segue duas principais visões sobre os princípios de tradução utilizados para a produção de suas traduções da Bíblia para a comunidade, enquanto que no meio acadêmico, autores com ênfases judaicas, tais como Meschonic (2010a) ${ }^{11}$ com sua conhecida visão formalista e Campos (2000) ${ }^{12}$, também bem conhecida visão de interferências do concretismo, tenham visões que seriam denominadas por Nida e Taber (1982, p. 22) de "Correspondência Formal"13 e por Beekman e Callow (1992, p. 18-28) de "tradução literal demais". Na outra linha da comunidade mais religiosa judaica, é nos dito que as traduções são feitas para a comunidade com base na tradição rabínica de interpretação, conforme lemos na Bíblia da Editora Sêfer (Bíblia Hebraica, 2006, p. 7):

A isto se propõe esta edição do TANA프, que busca simultaneamente ser fiel ao original hebraico e à tradição rabínica, e a manter a clareza da linguagem corrente em português ${ }^{14}$.

(...) uma versão do texto bíblico mais apurada e isenta de influências externas que, por diferentes razões, alteram-no ou o adaptaram às suas próprias conveniências e necessidades teológicas.

(...)

Mas usou-se a inserção criteriosa de certas palavras (normalmente entre parênteses) quando extremamente necessárias à compreensão do texto, ou adotouse determinada tradução não literal a fim de possibilitar sua leitura à luz dos ensinamentos e orientações técnicas dos Sábios do Talmude e dos consagrados exegetas bíblicos judeus dos últimos 2 mil anos. ${ }^{15}$

11 Sobre seus princípios de tradução o autor diz (2010b, p. 5): "Meu problema é o problema de todos. Já que é o problema das atividades da linguagem. Eu enuncio como uma poética do traduzir, que é uma ética do traduzir, uma política do traduzir. O problema é o do poema a traduzir, do traduzir como poema. Questão de ponto de vista, não de área linguística. Trabalhei em várias áreas, dedicando-me mais, ultimamente, a retraduzir a Bíblia. Retraduzir supõe sem dúvida uma teoria de conjunto, mais intensamente ainda do que traduzir o que nunca foi traduzido. Se bem que a própria historicidade de todo ato de tradução faça, antecipadamente, de todo traduzir um traduzir situado pela história do traduzir." Nota-se aqui um jogo de palavras simbólicas numa elaboração teórica do ato de traduzir, presença do simbolismo francês de Mallarmé, citado por Meschonic (op. cit., p. 5).

12 Campos (2000, p. 11) define seus princípios de tradução com as seguintes palavras: "Enfatizarei, apenas, que não busco, em minhas traduções bíblicas, uma suposta "autenticidade" ou "verdade" textual. Meu empenho está em alcançar em português, segundo linhas e critérios aconselhados por minha longa e variada prática de tradutor de poesia e sugeridos também pela própria natureza do orginal, uma reconfiguração - em termos de "transcriação" - das articulações fonossemânticas e sintático-prosódicas do texto de partida. Tenho por objetivo obter, através da operação tradutora, um texto comparativa e coextensivamente forte, enquanto poesia em português, a ser cotejado com as versões convencionais como um virtual exemplo do que há por fazer, nessa matéria, em nosso idioma". Mais uma vez percebemos uma proposta de "nova abordagem" de tradução da Bíblia Hebraica em contraste com as versões que Campos chama de "versões convencionais". O trabalho do autor é semelhante ao de Meschonic (2010), Campos (2000, p. 18-23) reconhece a influência e importância do trabalho de Meschonic também compara seu trabalho com as versões tradicionais, tanto cristãs como judaicas (ver Campos, op. cit., p. 18).

13 Também em Nida e Waard (1986, p. 36-44).

14 Os mesmos pressupostos da equivalência dinâmica defendidos por Nida (1982; 1986), por Sayão (2001) e pela SBB (2005, p. iv-v, 2008).

15 Aqui, a força da tradição interpretativa do judaísmo rabínico aparece no discurso dos tradutores, as inserções que condenam nos primeiros parágrafos e que chamam de "...conveniências e necessidades teológicas" são as mesmas que inserem nos parênteses de sua tradução, como será visto posteriormente. 
Vertentes modernas denominadas de Judaísmo Messiânico, que buscam manter certas tradições judaicas ortodoxas, acrescentando às mesmas, tradições cristãs com base no texto do Novo Testamento, também absorveram os paradigmas de tradução de Nida em seus trabalhos de tradução, tanto da Bíblia Hebraica quanto do Novo Testamento. O líder Judeo-Messiânico David H. Stern, tradutor de uma versão da Bíblia denominada Complete Jewish Bible, traduzida em português como Bíblia Judaica Completa: o Tanakh [AT] e a B'rit Hadashah [NT] na introdução dessa obra, em português, faz as seguintes afirmações:

Existe uma escala de medição das traduções. Em um lado da escala, estão as traduções "literais", que reproduzem a língua na língua receptora (português) as formas gramaticais da língua-fonte (hebraico, aramaico e grego); os tradutores denominam "traduções de equivalência formal".

(...)

No outro extremo da escala, encontram-se as "traduções de equivalência dinâmica", que objetivam reproduzir na língua receptora o significado compreendido pelos leitores originais sem, entretanto, transpor as formas gramaticais da língua-fonte.

(...)

Nessa escala, a Bíblia Judaica Completa localiza-se mais próxima do extremo da equivalência dinâmica. Em pontos específicos, relacionados à sua judaicidade, ela assim procede de forma militante. (STERN, 2010, p. 19)

As traduções da Bíblia, outrora feitas à medida da necessidade, conforme princípios teológicos das respectivas tradições, tanto judaicas quanto cristãs, agora, conforme se nota pela exposição acima, são elaboradas de acordo com as teorias de tradução do campo da linguística, teorias essas transformadas pelo discurso ${ }^{16}$ tradicional teológico, anteriormente eram traduções fundamentadas nas confissões de cada tradição, são agora envolvidas pelo discurso acadêmico, mantendo as tradições, mas com uma fundamentação teórico-científica.

Tendo estabelecido nas linhas acima um delineamento geral das discussões a respeito do impacto da teoria de Nida na tradução da Bíblia, é preciso analisar, especificamente, a teoria das equivalências e como as versões bíblicas se utilizam dela, o que será feito nos tópicos seguintes.

\subsubsection{Equivalência formal (Correspondência Formal)}

Nida (1964, p. 165) divide as traduções, polarizando-as em dois tipos: traduções

\footnotetext{
16 Para Fairclough (2001, p. 91) "O discurso contribui para a constituição de todas as dimensões da estrutura social que, direta ou indiretamente, o moldam e o restringem; suas próprias normas e convenções, como também relações, identidades e instituições que the são subjacentes. O discurso é uma prática, não apenas de representação do mundo, mas de significação do mundo, constituindo e construindo o mundo em significado."
} 
governadas por princípios de "equivalência formal"17 e traduções governadas por princípios de "equivalência dinâmica". O autor passa, então, a definir o que entende por uma tradução governada por equivalência formal com as seguintes palavras:

Para poder entender um pouco mais plenamente as características de diferentes tipos de tradução, é importante analisar em maiores detalhes os princípios que governam uma tradução que tenta reproduzir uma equivalência formal. Tais traduções por equivalência formal (ou E-F) são basicamente orientadas pelo texto fonte ${ }^{18}$; isto é, são projetadas para revelar tanto quanto possível a forma e o conteúdo da mensagem original.

Fazendo assim, uma tradução E-F procura reproduzir vários elementos formais, incluindo: (1) unidades gramaticais, (2) consistência no uso de palavras, e (3) significados nos termos do contexto fonte. A reprodução de unidades gramaticais pode consistir em: (a) traduzir substantivos por substantivos, verbos por verbos, etc.; (b) manter todas as frases e sentenças intactas (i.e. as unidades não são divididas e reajustadas); e (c) preservando todos os indicadores formais, e.g. marcas de pontuação, pausas de parágrafos, e indentação poética.

A análise crítica que Nida faz às traduções que ele denomina por "Equivalência Funcional" passou a ser também a crítica dos novos tradutores da Bíblia, principalmente no meio protestante. A nova teoria encontrou adeptos entre os "biblistas" tradutores, de modo que passou a ser a teoria base para a produção de novas traduções, essa popularização da teoria de Nida acabou por alcançar até mesmo os meios católicos por meio da tradução protestante conhecida como NTLH, pois, em fevereiro de 2005 a editora católica Paulinas lançou a Bíblia Sagrada - Nova Tradução na Linguagem de Hoje. Essa tradução foi feita pela Sociedade Bíblica do Brasil, que se utilizou dos princípios de equivalência funcional ou dinâmica de Nida para produzi-la, foi lançada com fins ecumênicos ${ }^{19}$ pela editora Paulinas ${ }^{20}$ com

17 Num refinamento posterior da teoria Nida e Waard (1986, p. 36) mudará o termo para "Correspondência Formal", entretanto, o termo "Equivalência Formal" permanecerá o mais utilizado por tradutores da Bíblia que adotaram a teoria de Nida em seus trabalhos, como a já citada NTLH (BÍBLIA DE ESTUDO NOVA TRADUÇÃO NA LINGUAGEM DE HOJE, 2008, p. vi).

18 source-oriented.

19 A versão recebeu o chamado imprimatur, a autorização da CNBB para poder ser utilizada pelo público católico.

${ }^{20}$ O texto dessa tradução foi feito por uma comissão de cunho protestante, denominada pela SBB como "Comissão de Tradução", contudo, na versão publicada pela Paulinas foram inseridos os livros deuterocanônicos (conhecidos como apócrifos pelos protestantes), que seguem uma tradução feita pelas Sociedades Bíblicas Unidas (UBS, United Bible Society), entidade que mantém vínculos entre as Sociedades Bíblicas em todo o mundo. Também foram acrescentados elementos paratextuais de orientação católica, para informações sobre as diferenças dessa versão com a versão original protestante, ver:

$<$ http://www.paulinas.org.br/loja/DetalheProduto.aspx?IDProduto $=6898>$, acesso em $01 \mathrm{mar}$ 2012 . 
permissão da Sociedade Bíblica do Brasil. ${ }^{21}$

Em defesa das novas traduções e procurando encontrar "erros" nas traduções tradicionais, as Sociedades Bíblicas mais alinhadas às teorias de tradução utilizam-se da mesma linguagem de Nida, às vezes até mesmo sem citar a fonte, como se pode notar na seguinte transcrição:

Basicamente a diferença entre uma tradução como a de Almeida e a Nova Tradução na Linguagem de Hoje está nos princípios que nortearam o processo de versão. $\mathrm{Na}$ primeira foi utilizado o princípio de equivalência formal, que procura seguir a ordem das palavras que pertencem à mesma categoria gramatical do original. $\mathbf{O u}$ seja, traduzir um verbo por um verbo, um substantivo por um substantivo e assim por diante ${ }^{22}$. A segunda baseou-se nos princípios da equivalência funcional ou dinâmica, reproduzindo o sentido dos originais de maneira fluente, como a maioria da população fala. (A ARTE DE TRADUZIR A BÍBLIA. A Bíblia no Brasil, Barueri, SP: SBB, n. 192, p. 13-16, Julho a Setembro de 2001)

Sayão (2001, p. 49) também utiliza o conceito de Nida de Equivalência Formal ${ }^{23}$ para se referir às versões mais tradicionais (ACF, ARC), discute brevemente a noção de fidelidade ao original, dizendo que há diferentes conceitos de fidelidade entre as várias traduções da Bíblia e de acordo com ele as traduções que se utilizam do princípio de equivalência formal não são capazes de produzir "uma versão que comunique adequadamente o texto original na língua receptora." (Sayão, 2001, p. 49).

\subsubsection{Equivalência Dinâmica (Equivalência Funcional)}

A respeito de traduções governadas pela equivalência dinâmica ou funcional, Nida (1964, p. 166) ${ }^{24}$ diz o seguinte:

Em contraste com as traduções por equivalência-formal, outras traduções são orientadas por equivalência dinâmica ${ }^{25}$. Em tais tipos de tradução, o foco de

\footnotetext{
21 Para uma excelente pesquisa sobre os processos e impactos dessa tradução ver Queiroz, (2007, principalmente os capítulos 5 e 6 ).

${ }^{22}$ Negritos nossos, temos aqui as mesmas palavras de Nida, porém sem referência à obra do autor.

${ }^{23}$ É importante notar que o termo Equivalência Formal, foi o que se cristalizou nas discussões acadêmicas sobre tradução, mas esse termo se refere à terminologia antiga de Nida $(1964,165-166)$ e não ao refinamento posterior do termo: Correspondência Formal em Nida e Taber (1982) e também em Nida e Waard (1986, p. 36).

${ }^{24}$ Todos os itálicos são do próprio Nida.

${ }^{25}$ De acordo com Nida (1986, p. 36) foi preciso aperfeiçoar o termo pois "A expressão 'equivalência dinâmica'
} 
atenção é direcionado, não mais pela mensagem do texto fonte, mas pela resposta do receptor. A tradução por equivalência dinâmica (ou E-D) pode ser descrita como algo que uma pessoa bilíngue ou bicultural poderia justificadamente dizer 'Essa é a maneira que eu diria isso". É importante, contudo, perceber, que uma tradução E-D não é meramente uma outra mensagem que é mais ou menos similar a mensagem original. É uma tradução, e tal qual deve claramente refletir o significado pretendido pela origem.

Uma maneira de definir uma tradução E-D é descrevê-la como 'a mais próxima equivalência natural ${ }^{26}$ da mensagem da língua-fonte'. Este tipo de definição contém três termos essenciais: (1) equivalente, que aponta para a mensagem da língua-fonte, (2) natural, que aponta para a língua receptora, e (3) mais próxima, que liga as duas orientações juntamente com a base do mais alto grau de aproximação. ${ }^{27}$

A Sociedade Bíblica do Brasil incorporou a teoria da equivalência dinâmica em sua tradução conhecida como TLH (Tradução na Linguagem de Hoje) e NTLH (Nova Tradução na Linguagem de Hoje), conforme lemos no prefácio da NTLH (2008, p. vi):

Os princípios seguidos nesta revisão foram os mesmos que nortearam o trabalho da primeira edição desta tradução. Diferente da tradução Almeida, que foi norteada pelos princípios de tradução de "equivalência formal", a NTLH orientouse pelos princípios de tradução de "equivalência funcional" 28 . Ao reproduzir o sentido dos textos originais, Almeida também procura reproduzir a forma dos textos originais, que muitas vezes é diferente do português simples e natural, e assim, requer um domínio da Língua Portuguesa que está acima da média da população brasileira. ${ }^{29}$ A NTLH, por sua vez, ao reproduzir também e efetivamente o sentido dos textos originais hebraico, aramaico e grego, expressa esse sentido de maneira simples e natural, assim como a maioria da população brasileira fala. Portanto, a Nova Tradução na Linguagem de Hoje continua sendo especialmente adequada ao trabalho de evangelização e é também muito apropriada para a leitura devocional em família, inclusive para as crianças.

A teorização feita por Nida foi amplamente usada pelas novas versões da Bíblia no meio protestante. Essa teorização polarizada criou a noção de que as versões mais tradicionais, que foram classificadas pela teoria como feitas por equivalência formal, estavam

tem, entretanto, levado a algumas confusões, desde que o termo 'dinâmica' tem sido entendido meramente em termos de alguma coisa que tem impacto e atração." Por esse motivo o autor preferiu mudar o termo para Equivalência Funcional.

${ }^{26}$ Pym (2010, p. 6-22) também se utiliza do termo Equivalência Natural como base de sua proposta de teoria de tradução em termos parecidos com as definições de Equivalência Dinâmica, feitas aqui por Nida.

${ }^{27}$ Tradução nossa.

${ }^{28}$ Nota-se aqui o sincronismo com as teorias de Nida já que o termo Equivalência Funcional, é, como já dito, um refinamento posterior da teoria do autor.

${ }^{29}$ Essa afirmação evidencia que a NTLH é uma tradução orientada ao leitor. 
fundamentadas em princípios linguísticos ultrapassados, sendo agora necessárias novas traduções, fundamentadas nas "mais atuais" e "melhores" teorias linguísticas de tradução, no caso, os conceitos e argumentos de Nida e outros nomes que são listados tais como: Saussure, Jakobson, Hjelmslev, Chomsky, Sapir, Bloomfield (citados por Sayão, 2001, p. 29). Tais expoentes dos estudos da linguagem são usados como fundamentadores do discurso dos novos tradutores e das novas versões, que passam a adotar, explícita ou implicitamente, os princípios teóricos da chamada Equivalência Dinâmica ou Equivalência Funcional.

No meio católico, a terminologia de Nida também alcançou o seu lugar nas discussões e manuais exegéticos. O uso das concepções sobre tradução seguem a linguagem e expressões clássicas dos trabalhos de Nida, como se pode ver nas seguintes afirmações de Silva (2000, p. 30-32):

(...) há dois tipos de tradução, a saber, (1) formal ou literal ${ }^{30}$ e (2) funcional ou dinâmica. Compreendamos a problemática de base: qualquer tradução deve contemplar dois elementos, o significado da frase e sua forma (ou expressão) lingüística.

A tradução formal preocupa-se em respeitar a forma lingüística do original. Por isso, sem deixar de ser compreensível, renuncia à compreensão imediata, para manter a fidelidade ao original. O resultado é uma versão mais pesada e mais cheia de redundâncias do que a tradução funcional.

Aqui, como Nida, Silva faz uma crítica às traduções por equivalência formal, mais à frente, o autor dará o seu apoio às traduções por equivalência dinâmica ou funcional, com as seguintes palavras (Silva, 2000, p. 32):

Por sua vez, a tradução funcional visa superar a dificuldade que o leitor hodierno tem em compreender a Sagrada Escritura. Para eliminar as tensões, modifica as estruturas frasais, utiliza palavras mais simples e articula as idéias de forma a tornar o texto imediatamente compreensível.

De acordo com Silva (2000, p. 32) a Bíblia Edição Pastoral e o lecionário dominical católico seguem uma tendência em adotar o tipo de tradução por equivalência dinâmica. $\mathrm{O}$ impacto da teoria de Nida alcançou, então, diferentes confissões teológicas num questionamento às traduções mais clássicas, que, segundo Nida, seguiam um princípio de tradução por equivalência dinâmica.

\footnotetext{
${ }^{30}$ Todos os negritos são do próprio autor.
} 
Tendo, portanto, discutido a teoria de Nida e o impacto que teve nas traduções da Bíblia, abordaremos no próximo tópico, de forma abreviada, qual o estado da arte das teorias de tradução e a aplicação dessas teorias na discussão sobre a tradução da Bíblia.

\subsubsection{O Estado da Arte}

Pym (in: BALLARD; D’HULST, 1997, p. 21) faz uma observação crítica sobre as teorias de tradução que frequentemente assumem uma bipolaridade de termos, sejam eles quais forem. De acordo com autor, esse tipo de bipolarização das teorias de tradução remontam a Cícero: "ut interpres / ut orator", Jerônimo: "non verbo verbum sed sensu sensum", e continuam em teorias modernas como em Nida: "equivalência formal / equivalência dinâmica" e Newmark: "tradução semântica / tradução comunicativa". Pym (op.cit., p. 21) questiona: "Por que dois métodos e não três, quatro ou dez?”.

Tentativas de definir uma ética para os tradutores e até mesmo um padrão de melhores práticas para os profissionais da área são definidas pela Associação Americana de Tradutores (apud CHESTERMAN, 2001, P. 150-151):

\section{American Translators Association Code of Professional Conduct and Business Practices}

1. As a Translator or Interpreter, a bridge for ideas from one language to another and one culture to another, I commit myself to the highest standards of performance, ethical behavior, and business practices.

A. I will endeavor to translate the original message faithfully, to satisfy the needs of the end user(s). I acknowledge that this level of excellence requires:

2. mastery of the target language equivalent to that of an educated native speaker,

3. up-to-date knowledge of the subject material and its terminology in both languages,

4. access to information resources and reference materials, and knowledge of the tools of my profession,

5. continuing efforts to improve, broaden, and deepen my skills and knowledge.

B. I will be truthful about my qualifications and will not accept any assignments for which I am not fully qualified.

C. I will safeguard the interests of my clients as my own and divulge no confidential information.

D. I will notify my clients of any unresolved difficulties. If we cannot resolve a dispute, we will seek arbitration.

E. I will use a client as a reference only if I am prepared to name a person to attest to the quality of my work.

F. I will respect and refrain from interfering with or supplanting any business relationship between my client and my client's client. 
Tradução:

\section{Associação de Tradutores Americanos}

\section{Código de Conduta Profissional e Práticas Comerciais}

1. Como um Tradutor ou Intérprete, uma ponte para ideias de uma linguagem para outra e de uma cultura para outra, eu me comprometo a seguir os padrões mais altos de performance, comportamento ético, e práticas de negócios.

A. Eu irei me esforçar para traduzir a mensagem original fielmente, para satisfazer as necessidades do(s) usuário(s) final(is). Eu reconheço que este nível de excelência requer:

2. Domínio da língua receptora equivalente à de um falante nativo educado,

3. Conhecimento atualizado do material em questão e sua terminologia em ambas linguagens,

4. Acesso a recursos de informação e materiais de referência, e conhecimentos das ferramentas de minha profissão,

5. Esforço contínuo para melhorar, ampliar e aprofundar minhas habilidades e conhecimentos.

B. Eu serei sincero sobre minhas qualificações e não aceitarei nenhuma atribuição da qual eu não esteja plenamente qualificado.

C. Eu protegerei os interesses de meus clientes como se fossem meus próprios interesses e não divulgarei informação confidencial.

D. Eu notificarei meus clientes a respeito de quaisquer dificuldades não resolvidas. Se nós não resolvermos um litígio, nós procuraremos arbitragem.

E. Eu usarei um cliente como referência somente se eu estiver preparado para citar uma pessoa que ateste a qualidade do meu trabalho.

F. Eu respeitarei e me absterei de interferir em qualquer tipo de relacionamento de negócios entre meu cliente e o cliente de meu cliente.

Gutt (2000, p. 1-22) $)^{31}$ faz uma excelente discussão sobre as dificuldades decorrentes da multiplicidade de teorias de tradução e da dificuldade de delimitar o objeto de estudo e o campo científico da ciência ou arte da tradução.

Para Gutt (2000, p. 4) “(...) a abordagem multidisciplinar da tradução traz consigo uma séria ameaça para o próprio objetivo o qual ela reivindica: o desenvolvimento da ciência da tradução”. Essa dificuldade de definir o que é tradução, em qual área da ciência se encaixa, se deve ser tratada como uma nova área da ciência, se é arte em vez de ciência tem conduzido a acalorados debates nos meios acadêmicos. Nesse debate, a tradução da Bíblia acaba tendo por

\footnotetext{
${ }^{31}$ Gutt é consultor internacional da SIL (Summer Institute of Linguistics, Inc) agência de desenvolvimento linguístico que também trabalha com traduções bíblicas. A abordagem na qual Gutt baseia suas reflexões teóricas é conhecida como Relevance Theory (Teoria da Relevância), também discutida em CAMPOS, Jorge; RAUEN, Fábio José (orgs.). Tópicos em Teoria da Relevância. Porto Alegre: EDIPUCRS, 2008.
} 
um lado um grupo mais conservador que quer preservar as traduções consideradas literais, preservando mais a forma da língua e cultura de origem, e um outro grupo, que pretende estar mais alinhado às teorias de tradução escolhidas como fundamento teórico-metodológico para produção de novas versões, mais livres ou mais voltadas à língua e cultura alvo, ou de destino. $^{32}$

A abordagem de Nida surgiu como teoria contestatória das antigas traduções da Bíblia que se preocupavam com uma preservação mais literalista do texto original, as comparações que faz para desenvolver sua teoria têm como base principalmente os textos da KJV (como exemplo de tradução por equivalência formal). Semelhantemente, as traduções brasileiras que procuram usar os paradigmas de Nida, contestam principalmente as versões tradicionais brasileiras conhecidas pelas siglas ARC, ACF e ARA. Curiosamente, a abordagem de Nida foi suplantada pelas novas teorias de tradução e passa a ser listada, agora, como uma teoria que faz parte de uma visão tradicional de tradução.

A teoria das equivalências de Nida alcançou diversos adeptos e muitas traduções foram feitas com base nessa teoria (ver notas 6, 11,37). A teoria serviu também como um referencial acadêmico para a crítica das antigas versões tradicionais no meio protestante, como a KJV em inglês e a RC, ACF em português. Evidente que a teoria de Nida, tendo sido elaborada em meados da década de 1960, já se encontra desatualizada em termos acadêmicos, mas já se estabilizou como base de crítica das versões antigas como se fosse uma teoria atual. $^{33}$

O debate no meio protestante não se desenvolveu e a dualidade entre traduções absorveu a terminologia de Nida, de modo que as traduções da Bíblia são analisadas de acordo com a polaridade das equivalências. Traduções mais próximas da literalidade do texto fonte são classificadas como traduções por equivalência formal, enquanto que traduções consideradas mais livres são classificadas como por equivalência dinâmica.

À parte dessas nomenclaturas, não são praticados outros princípios de tradução e mesmo os princípios de Nida são aplicados às traduções da Bíblia como um todo, desprezado os diferentes tipos de texto (prosa, poesia, epístola, salmos, provérbios e tantos outros textos singulares da literatura bíblica), prática que o próprio Nida desaconselharia.

No capítulo 11 de seu Toward a Science of Translating (NIDA, 1964, p. 241-251) Nida trata de vários procedimentos necessários que devem orientar uma tradução. Nesse capítulo

\footnotetext{
32 Os termos consagrados pelos teóricos da tradução são: ST (Source Text, Texto de Fonte), TT (Target Text, Texto de Destino), também são usados os termos SL (Source Language, Língua Fonte) e TL (Target Language, Língua Alvo), ver Munday (2008).

${ }^{33}$ Nida continuou a defender a sua teoria até a sua morte em 2011.
} 
ele expõe vários princípios de análise para que se faça uma tradução, que envolvem: língua fonte e língua alvo, texto fonte, características léxico-gramaticais da unidade imediata, contexto do discurso, contexto comunicativo, contexto cultural da língua fonte, contexto cultural da língua receptora, dentre outros elementos que ele explica com problemáticas tiradas do próprio texto fonte para esclarecer ao leitor a sua abordagem. Mas, mesmo diante de todas esses procedimentos, os exemplos e as análises de Nida dão enfoque maior ao nível de estrutura da frase ou no que se refere aos seus exemplos bíblicos, ao versículo.

Embora as traduções protestantes digam utilizar a teoria de Nida, na verdade, usam a teoria somente como um argumento pseudo-acadêmico para a produção e venda de novas versões produzidas de acordo com "novos princípios de tradução", contudo, não aplicam com coerência os próprios princípios de Nida e, muito menos, procuram produzir novas traduções com as teorias mais recentes.

Já nas décadas de 1960-1970, os princípios de equivalência de Nida começam a ser criticados ou ampliados para se estenderem a níveis mais amplos do texto. Discorrendo sobre teorias funcionalista de tradução das décadas de 60-70, Venuti (2004, p. 145) diz o seguinte:

Katharina Reiss ${ }^{34}$ apresenta uma sofisticada tipologia que mostra as tensões lógicas dentro dos conceitos reinantes na literatura. Como ela argumenta no ensaio aqui reimpresso, uma tradução por 'equivalência funcional' precisa ser baseada em uma 'análise detalhadamente semântica, sintática e pragmática' do texto estrangeiro. Mas a análise pragmática sempre tem o risco de revisar qualquer relato prévio de significado, pois este define o sujeito da análise. O tradutor pragmático não analisa simplesmente a característica linguística e cultural do texto estrangeiro, mas o reverbaliza de acordo com os valores de uma diferente língua e cultura, frequentemente aplicando o que House chama de um 'filtro' para ajudar a compreensão do receptor a respeito das diferenças.

O funcionalismo dentro das muitas teorias de tradução de seu tempo lança dúvidas em elaboradas tipologias de equivalência por sugerir que elas são meramente construções, esquemas idealizados não realizados em traduções atuais. Ou mais precisamente, o ideal se torna possível somente dentro de uma estreita faixa de texto em específicas situações institucionais, incluindo programas de treinamento de tradutores. (tradução nossa).

Abordagens mais recentes (década de 1990 em diante) utilizam-se dos paradigmas linguísticos da Análise do Discurso para propor novos paradigmas de tradução com base nessa teoria. Segundo Mittmann (2003), as visões de Nida, Theodor e Rónai são exemplos de paradigmas tradicionais na teoria de tradução, enquanto que Arrojo, Venuti, Aubert e Hermans

\footnotetext{
${ }^{34}$ Negritos do autor.
} 
são propostas contestadoras dessas teorias tradicionais. Sintetizando a discussão de Mittman (2003, p. 33-34), num paralelo entre as teorias tradicionais e as contestadoras, temos o seguinte quadro ${ }^{35}$ :

\begin{tabular}{|c|c|}
\hline Teoria Tradicionais de Tradução & Teorias Contestadoras de Tradução \\
\hline $\begin{array}{l}\text { Eugene A. Nida, Erwin Theodor e Paulo } \\
\text { Rónai }\end{array}$ & $\begin{array}{l}\text { Francis H. Aubert, Rosemary Arrojo, } \\
\text { Lawrence Venuti e Theo Hermans }\end{array}$ \\
\hline - idealização do texto original; & $\begin{array}{l}\text { - sentido como matriz para a realização da } \\
\text { tradução; }\end{array}$ \\
\hline - tradução como transparência; & $\begin{array}{l}\text { - o sentido não é reflexo das intenções do } \\
\text { autor, essas intenções não são acessíveis nem } \\
\text { ao tradutor nem ao leitor; }\end{array}$ \\
\hline $\begin{array}{l}\text { - tradução como cópia deturpadora do } \\
\text { original; }\end{array}$ & - o sentido não está contido no texto original; \\
\hline - apagamento do tradutor; & $\begin{array}{l}\text { - o sentido do original e a voz do autor do } \\
\text { original não são senão uma imagem } \\
\text { construída pelo tradutor; }\end{array}$ \\
\hline \multirow[t]{4}{*}{$\begin{array}{l}\text { - fidelidade do tradutor ao original e ao } \\
\text { leitor da tradução; }\end{array}$} & $\begin{array}{l}\text { - o sentido é resultado de um ato de } \\
\text { interpretação do tradutor; }\end{array}$ \\
\hline & $\begin{array}{l}\text { - a interpretação é determinada por fatores } \\
\text { externos (cosmovisão, ideologia, padrões } \\
\text { estéticos, etc); }\end{array}$ \\
\hline & $\begin{array}{l}\text { - o tradutor é ativo e responsável sobre a } \\
\text { tradução, é transformador e produtor do ato } \\
\text { de tradução; }\end{array}$ \\
\hline & $\begin{array}{l}\text { - a voz do tradutor está presente em todo o } \\
\text { texto da tradução, a invisibilidade do tradutor } \\
\text { é uma ilusão. }\end{array}$ \\
\hline
\end{tabular}

Visões mais literalistas de tradução são vistas pelos teóricos do discurso como paradigmas logocêntricos ${ }^{36}$, que de acordo com esses teóricos são visões ultrapassadas que têm como ilusão a autonomia do sujeito (autor) e do tradutor como simples intermediário entre o autor original e o leitor. Para a análise do discurso, não existe autor autônomo, já que a obra literária é fruto da cosmovisão do autor, o qual não é agente livre na constituição da obra literária, mas sofre a interferência da sua visão de mundo e do ambiente social em que vive.

O tradutor também não é visto pela teoria do discurso como agente livre e neutro, é simplesmente um leitor que têm suas próprias concepções ou imagens formadas a respeito do

\footnotetext{
${ }^{35}$ Quadro elaborado e adaptado com base nas discussões de Mittmann (2003, p. 33-34).

${ }^{36}$ Termo extraído da palavra grega $\lambda o ́ \gamma o \zeta$ (logos), que significa palavra, verbo e utilizado por Jacques Derrida para se referir às visões filosóficas platônicas sobre o conceito do ser e ao entendimento teológico de fé “...entendido como pensamento auto-revelador ou razão cósmica.” (LUCY, 2004, p. 71).
} 
autor e da obra, e seu trabalho não passa de uma interpretação da obra original transformada em uma tradução para a língua alvo.

Essa concepção de tradução é notada na crítica de Arrojo à "tradição logocêntrica" (1993, p. 177-178):

\begin{abstract}
A tradição logocêntrica vê a leitura e a tradução como instâncias de recuperação e transferência de significados e, conseqüentemente, invoca a noção de fidelidade como a principal questão ética que não apenas orienta a adequação desse resgate e dessa transferência, mas também presta as devidas homenagens ao autor do texto de origem. Esse quadro referencial em que o logocentrismo encaixa qualquer ato de leitura pressupõe, naturalmente, significados estáveis e resgatáveis que estariam "presentes" no chamado "original" e cuja origem se encontra, em última análise, presa às intenções conscientes de um autor. Em termos logocêntricos, o enredo teórico reservado à tradução e à leitura é conciliador e harmônico: da mesma forma em que o autor conscientemente insere significados em seu texto, um leitor adequado deve ser capaz de extrair do veículo da linguagem os significados nele depositados pelo autor e, no caso da tradução, também de transferi-los "fielmente" e "sem perdas" - para a língua-alvo.
\end{abstract}

A proposta da teoria do discurso no campo da tradução, é, então, opor-se à visão logocêntrica e questionar essa premissa da possibilidade de significados estáveis e "presentes" no texto (Arrojo, 1993, p. 178), propõe-se então uma desconstrução, que busca desestabilizar a harmonia logocêntrica.

O desconstrucionismo teve grande impacto na interpretação e tradução da Bíblia, bem como na teoria da equivalência de Nida. Nida questionava a literalidade como tradicional e incapaz de transmitir o "verdadeiro significado" do texto original, propunha então um texto mais fluido, o que seria mais adequado ao entendimento do leitor e mais coerente com os objetivos missionários de divulgação da mensagem do evangelho ${ }^{37}$ às muitas línguas existentes no mundo. Mas, para a desconstrução, não há autor autônomo, não há tradutor transparente, só há leitor potencial, logo, termos como "autor", "original" não cabem mais nessa nova abordagem discursiva sobre as teorias de tradução. ${ }^{38}$

\footnotetext{
${ }^{37}$ Nos estudos teológicos de linha protestante chamados de missiologia e antropologia missionária, a obra de Nida é largamente usada como paradigma de entendimento de novas culturas, Nida escreveu uma obra voltada para a missiologia: NIDA, Eugene. Customs and Cultures. Passadena: Willian Carey Library, 1975, publicado no Brasil de forma adaptada com o título de Costumes e Culturas: Uma Introdução à Antropologia Missionária. Barbara Burns Décio de Azevedo Paulo Barbero F. de Carminati, baseado na obra de E. A. Nida. São Paulo: Vida Nova, 1995. Taber, coautor da famosa obra: NIDA, Eugene A.; TABER, Charles R. The Theory and Pratice of Translation. Leiden: United Bible Society, 1982, escreve outra obra também voltada à missiologia: TABER, Chareles. To Understand the World, to Save the World: The Interface between Missiology and Social Science. Harrisburg: Trinity Press International, 2000.

${ }^{38}$ Voltaremos à abordagem discursiva desconstrucionista no tópico abaixo relacionado à tradução e tradição interpretativa.
} 
Se as teorias de Nida já causaram grandes discussões no campo teológico, o que causaria a produção de uma tradução da Bíblia alinhada com o desconstrutivismo?

O texto bíblico, já sensível por sua própria natureza e uso nas mais diversas tradições religiosas, acaba por ser ainda mais sensível em confissões protestantes cuja visão e tradição da literalidade foi sempre valorizada e ardentemente defendida. A teorização desse tipo de texto chamado de sensível é discutida em Hatim e Mason (1997, p. 111-112). A Bíblia é vista como um Texto Sensivel ${ }^{39}$, pois se trata de um Texto Sagrado para muitas religiões. Essa sensibilidade e sacralidade do texto acaba por conduzir a interferências da tradição interpretativa das diversas confissões religiosas, que, para manterem sua identidade confessional e suas práticas tradicionais de manifestações religiosas, necessitam que os textos bíblicos signifiquem aquilo que suas tradições interpretativas querem que eles signifiquem, portanto, antes de passar pelo "filtro" da tradição interpretativa, tais textos devem ser traduzidos de acordo com essa mesma tradição.

Segundo Lopes (2008, p. 21-28):

Como textos passíveis de suscitar objeção, os textos sagrados revelam-se como sensíveis na medida em que demonstram um envolvimento afetivo por parte daqueles que o veneram. Todavia, boa parte dos leitores desses livros, e, sobretudo, os leitores da Bíblia, somente os acessam por meio da tradução. Assim, se, por um lado, tem-se um objeto quase que 'intocável', que não pode ser burlado ou defraudado, por outro, verifica-se a tradução como uma ferramenta que 'toca' essa modalidade de texto e, por assim fazê-lo, sujeita-se à total sacralização ou à total desmoralização.

O que precisa ser analisado é como a tradução da Bíblia se manifesta como texto sensível dentro das tradições interpretativas como um todo. Independente do cânon ${ }^{40}$ adotado pelas diferentes tradições religiosas, é preciso analisar, como textos específicos, ainda mais sensíveis, por terem historicamente conotações teológicas importantes para determinadas confissões religiosas, podem sofrer interferências em suas traduções e interpretações.

O termo equivalência continua sendo adotado como parâmetro de análise entre as estruturas da língua dentro das várias propostas de teoria de tradução, Popovič (apud BASSNET, p. 53) distingue quatro tipos de equivalência na tradução:

\footnotetext{
${ }^{39}$ Expressão usada por Hatim e Mason (1997, p. 111-122).

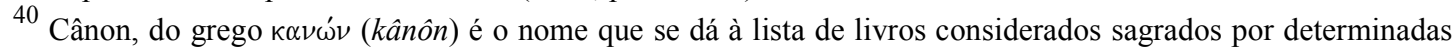
confissões religiosas. O judaísmo rabínico considera canônicos os 39 livros do que chamam "דַ (Tanak), enquanto que os caraítas consideram canônicos somente os 5 primeiros livros da Torah. Entre os cristãos há diversos "cânons", ou seja, a Bíblia é um livro diferente de acordo com as diferentes tradições religiosas.
} 
1) Equivalência linguística, quando existe homogeneidade ao nível linguístico entre os textos da língua fonte e da língua alvo, i.e., tradução palavra por palavra.

2) Equivalência pragmática, quando existe equivalência ao nível dos 'elementos do eixo expressivo paradigmático', i.e., equivalência gramatical, que Popovič considera uma categoria mais elevada do que a equivalência lexical.

3) Equivalência estilística, quando se verifica uma 'equivalência funcional de elementos entre o original e a tradução visando a identidade expressiva de uma invariante com sentido idêntico'.

4) Equivalência textual (sintagmática), quando existe equivalência ao nível da estruturação sintagmática do texto, i.e., equivalência de forma e de formulação.

As teorias de tradução, em sua grande maioria, discutiram os problemas de tradução principalmente no que diz respeito à equivalência linguística. No âmbito da tradução da Bíblia, estudiosos tanto judeus como cristãos, acostumados a dissecar o texto sagrado palavra por palavra, quando discutiram a tradução, analisaram-na com os mesmos princípios que utilizaram para interpretar o texto da Bíblia.

Nida $(1964,1982,1986)$ dá grande enfoque à estrutura léxica e aos problemas de equivalência da tradução de termos, modos verbais e às dificuldades de transposição dos conceitos da língua bíblicas para as línguas modernas. Pouco esforço foi feito por Nida e seus seguidores para analisar a tradução na estrutura do texto em outros níveis de equivalência. ${ }^{41}$ Este trabalho, felizmente, foi feito por pesquisadores posteriores como Baker (1994, p. 119260), que analisa diversos outros níveis de equivalência ${ }^{42}$, tais como, equivalência textual: temas e estruturas de informação; equivalência textual: coesão e equivalência pragmática. A fim de teorizar estruturas mais amplas do texto, Baker define os conceitos de theme "o que é dito a respeito de algo" como tendo duas funções: "(a) atua como um ponto de orientação conectando trechos anteriores do discurso e, assim, mantendo um ponto de vista coerente e (b) atua como um ponto de partida para conectar o que segue e contribuir para o desenvolvimento dos trechos posteriores." (BAKER, 1994, p. 121-122). Enquanto que o rheme é "o que o falante diz a respeito do tema. É o objetivo do discurso. Como tal, é o elemento mais importante na estrutura da cláusula como uma mensagem, pois ele representa muito da informação que o falante quer transmitir ao ouvinte.”

Sendo a Bíblia um texto de uma grande variedade de estilos literários, diferentes assuntos e diferentes propósitos comunicativos, as discussões a respeito de sua tradução deveriam envolver não só uma equivalência, mas outras estruturas mais amplas da

\footnotetext{
${ }^{41}$ Nida dedica poucas páginas à análise da tradução na estrutura do discurso (NIDA, 1964, p. 210-213).

${ }^{42}$ Embora o foco de Baker seja tradução no sentido geral e não especificamente sobre tradução da Bíblia.
} 
comunicação.

Por causa do enfoque exagerado no nível da palavra, traduções da Bíblia acabaram sendo influenciadas por tradições interpretativas que procuraram conduzir a interpretação dos textos para os propósitos ideológicos defendidos por essas tradições, por isso, nos próximos tópicos, procuraremos analisar alguns exemplos de traduções existentes para verificarmos até que ponto tais textos podem ser considerados tradução, paráfrase, interpretação ou até mesmo um texto teológico carregado de ideologia. 


\section{Tradução ou teologia}

Nos casos analisados abaixo, tanto da tradição interpretativa cristã, quanto da rabínica, verificaremos que a interferência da tradição interpretativa do texto induziu os significados e alterou até mesmo o sentido de palavras nos léxicos da língua hebraica.

Em textos sensíveis, o establishment interpretativo se deu pela interferência da tradição teológica a respeito de tais textos, conduzindo a uma tradução e interpretação padronizadas. Esse reflexo do establishment interpretativo pode ser entendido na discussão de Carvalho Neto (in: GOHN; NASCIMENTO, 2009, p. 87) quando esse autor expõe o gráfico de Gutt a respeito da teoria de comunicação aplicada à tradução:

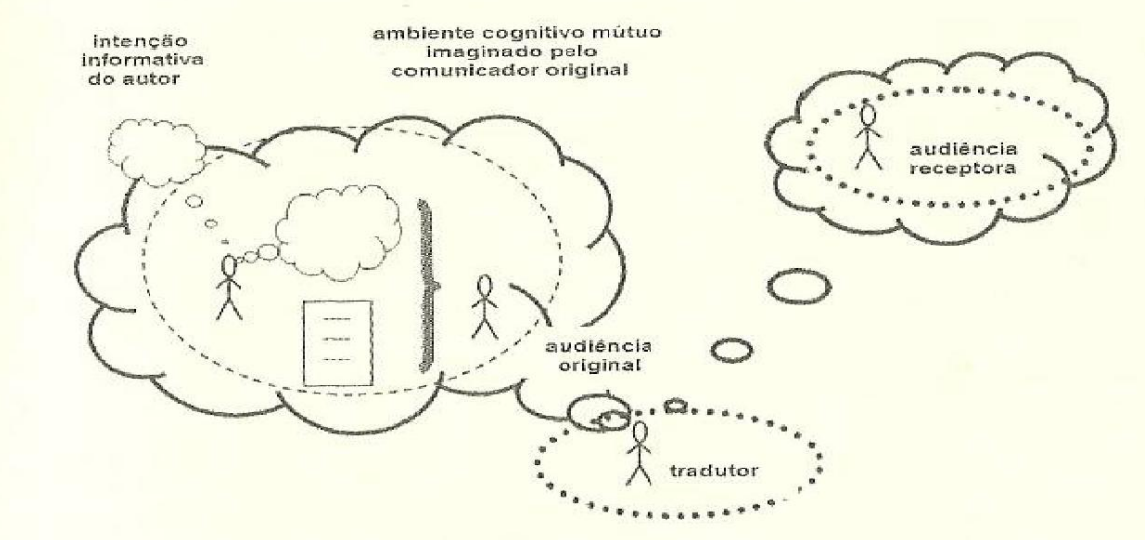

Figura 2 - Metarrepresentação em tradução (GuTT, 2004:81)

O gráfico acima pode ser ampliado levando em conta que o tradutor possui as suas próprias ideologias, discursos, e, no caso de nossa análise, tradição interpretativa e teológica já estabelecidas, tornando a tradução um comprometimento com essas concepções já padronizadas.

Com o intuito de verificarmos esses reflexos ideológicos-discursivos-teológicos em casos reais de tradução, escolhemos expor a interferência da tradição interpretativa na tradução do texto de Is 14.12 em versões de tradição cristã, assim como a interferência da tradição interpretativa rabínica na versão da Bíblia Hebraica da editora Sêfer em Is 9.5-6 e na Tradução do Novo Mundo das Escrituras Sagradas no texto de Gn 1.2 e 7.15. 


\subsection{Interferência teológica cristã na tradução de Isaías 14.12}

Um exemplo importante da interferência da teologia na tradução pode ser visto em algumas traduções cristãs do texto de Is 14.12. Este texto, associado a Ez 28.14-15 é interpretado no meio teológico cristão, como uma referência à queda de Satanás. Uma análise desses dois textos evidencia que em seus contextos imediatos se referem ao rei da Babilônia (Is 14.12) e ao rei de Tiro (Ez 28.14-15). Contudo, há uma interpretação cristãa ${ }^{43}$ da passagem que remonta aos séculos II e III d.C., que analisa a passagem como sendo uma referência indireta à queda de Satanás. Essa interpretação, já estabelecida há tanto tempo, faz com que a leitura dessa passagem seja condicionada pela tradição interpretativa estabelecida que culmina na interferência na tradução da passagem de Is 14.12 .

\subsubsection{Primeiras interpretações do texto de Is 14.12}

Tertuliano [160-230 d.C.], comentando sobre Isaías 14:12, disse: 'Isso deve significar o diabo...'. Orígenes [185-254 d.C.], também, prontamente identificou 'Lúcifer'"4 com Satanás. O Paraíso Perdido de John Milton contribuiu para a disseminação dessa noção errônea:

...Cidade e corte do infernal tirano,
Que Lúcifer chamado foi outrora
por se assemelhar da tarde a estrela...

Disso surgiu a perversão popular do belo nome Lúcifer para designar o Diabo. (ALDEN, $1968, \quad$ p. $2, \quad$ disponível em: < http://www.monergismo.com/textos/comentarios/lucifer-quem-oque_robertalden.pdf $>$ acesso em: 02 mar. 2011)

Desde então, a maioria das tradições interpretativas cristãs do texto o leem como uma referência à queda do diabo. Lange $(1878$, p. 187b), outro autor protestante, faz a seguinte

\footnotetext{
${ }^{43}$ Nem todos os teólogos cristãos interpretam a passagem dessa forma, como veremos abaixo.

${ }^{44} \mathrm{O}$ autor não especifica em qual obra Orígenes usa o termo Lúcifer, tendo em vista que a tradução da Vulgata foi feita somente entre 390 e 405 d.C. é improvável que Orígenes tenha utilizado esse termo para se referir ao diabo, é conhecido o texto de Orígenes $\pi \epsilon \rho \grave{\alpha} \alpha \chi \chi \hat{\omega} \nu$ (peri archôn) que chegou até nós por meio da versão de Rufino com o nome latino De principiis, nesse texto ocorre o nome Lúcifer, mas pelo fato de Orígenes ter escrito em grego, a tradução de Rufino (340/345 - 410 d.C.) é duvidosa, já que se sabe que essa versão é um texto parafraseado. Quanto a Tertuliano, o autor aqui também não especifica a obra, contudo não diz que Tertuliano usa o termo lucifer, somente indica a afirmação de Tertuliano de que é provável que Is 14.12 se refira ao diabo, evidenciando assim que essa interpretação já existia em sua época ou que ele está relacionando pela primeira vez essa interpretação. Uma outra possibilidade é que o termo lucifer tenha sido o termo utilizado pela antiga versão latina em Is 14.12, versão essa anterior a Vulgata, conhecida como Vetus Latina, mas por causa do estado fragmentário dessa antiga versão latina, não temos elementos para fazer essa comparação. Para detalhes sobre a Vetus Latina, ver Francisco (2008, p. 507-516); é conhecido um teólogo cristão de nome Lúcifer de Cagliari (+370-371), indício de que o nome não tinha sentido pejorativo nessa época.
} 
análise:

היריל [heylêl] estrela brilhante, é chamado 'filho da manhã', porque parece emergir da alvorada (comes alumnus aurorae). 'Nos céus do Sul, quando refletido nas ondas do mar, este planeta tem um brilho mais luminoso do que o que vemos daqui' (LEYRER in HERZ. R. Enxycl. XIX. P. 563). TERTULIANO, GREGÓRIO, O GRANDE, e posteriormente STIER, em referência a Lucas $10.18^{45}$, têm relacionado a estrela que cai do céu como Satã. Originando assim o nome Lúcifer

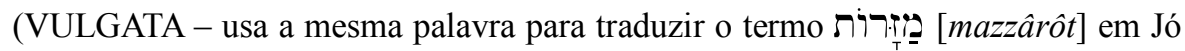

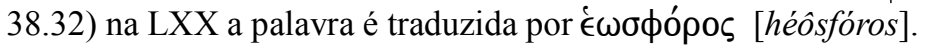

O reflexo da tradição interpretativa desse texto se tornou a interpretação teológica padrão, interferindo na tradução da maioria das versões cristãs em inglês, via Versão de Genebra e também via Versão King James. Em português, teve reflexo nas versões que foram influenciadas pela King James, principalmente a edição da Almeida Corrigida Fiel de 2007, onde o texto foi alterado, pois na edição de 1995 não existia a palavra Lúcifer e, sim, a tradução estrela da manhã, conforme veremos mais abaixo.

A palavra היליל [hêlêl] é o que se chama de hapax legomena, ou seja, uma palavra de ocorrência única ${ }^{46}$, não aparece em qualquer outro versículo na Bíblia Hebraica ${ }^{47}$, sendo assim de difícil tradução e identificação. Só é possível a tradução pela identificação da raiz, comparando com outras traduções antigas e com palavras cognatas em outras línguas semíticas. Devido à forte influência da tradição interpretativa nesse texto sensível, até mesmo os léxicos devem ser usados com cautela, pois muitos trazem essa influência nas definições desse vocábulo. ${ }^{48}$ Alden (1968, p. 5) também nos esclarece esse fato quando comenta:

A tradução da frase helel ben shachar em Isaías 14:12 não é fácil. O ben shachar

\footnotetext{
${ }^{45}$ A Edição WEBER-GRYSON (2007, p. 1.111a) da Vulgata Editio quinta , nas referências cruzadas, traz o texto de Lc 10.18 e de Ap 8.10 induzindo a uma interpretação cristã como referência ao diabo.

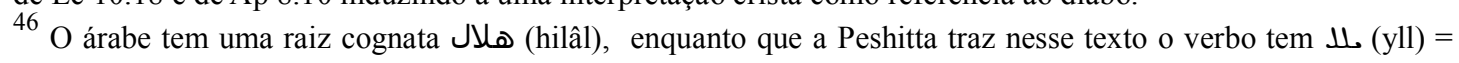
gemer, uivar, lamentar.

${ }^{47}$ A suposição de que a raiz esteja relacionada com o verbo hebraico 2 יל yll = gemer, uivar, lamentar; forma que ocorre duas vezes em Zc 11.2 é pouco provável, e mesmo assim não tem relação com a explicação da origem do nome Lúcifer o que resultaria numa tradução estranha do texto de Is 14.12.

48 Davidson (1993, p. 189-190) analisando a raiz הלל hll da qual a palavra é proveniente, coloca como possibilidade de tradução de Is 14.12 "estrela da manhã, Lucifer", contudo, não há qualquer base linguística para a possibilidade de tradução da palavra como Lúcifer. Berezin (1995) também coloca em maiúsculas como possível tradução do vocábulo e assim também o faz Gesenius (1840) que também coloca a opção de tradução Lucifer em letras maiúsculas. Even-Shoshan (1979, ט- ט, p. 516) corretamente não faz nenhuma relação com o vocábulo latino lucifer, explica somente que a raiz הליל hll é uma probabilidade, cita o texto de Is 14.12 onde aparece o vocábulo, o relaciona com a estrela da manhã e a hipótese de que seja nome de um rei Assírio. A força da tradição interpretativa interferiu até mesmo nos léxicos do hebraico que relacionam a palavra a uma tradição intepretativa cristã sem evidências linguísticas. No Ugarítico ocorre a expressão parecida: bnt hll = 'filha da alva [?]'.
} 
não é o problema. A frase significa "filho da alva" ou similares. A estrela da manhã é o filho da manhã. O termo hebraico ben - "filho" significa algo muito próximo, dependente ou descrito pela palavra seguinte no estado absoluto. Mas helel é um nome? É um substantivo comum? É um verbo? A palavra helel aparece em Zacarias 11:2 em paralelo com um verbo cujas letras radicais são yll. Assim, ambos significam "uivo" ou "berro" e são aparentemente onomatopeias. Em Ezequiel 21:12 (v. 17 em hebraico) temos uma situação similar. Ali helel é paralelo a z'q, que significa "gritar". Jeremias 47:2 tem uma forma relacionada (hiph'il) $e$ ali a palavra é traduzida como "lamento". A versão síria, entre outras, entende assim a palavra em questão: "Como caíste do céu! Uivo na manhã...". (disponível em: $\quad<\mathrm{http} / / /$ monergismo.com/wp-content/uploads/lucifer-quem-oque_robertalden.pdf $>$ acesso em: 02.03.2012)

\subsubsection{O texto fonte de Isaías 14.12}

Quando há dúvida a respeito da tradução de uma palavra ou versículo bíblico, é preciso recorrer ao texto fonte. Faremos aqui uma análise palavra por palavra, uma tradução interlinear e uma tradução por equivalência formal ${ }^{49}$ para compreendermos melhor a construção hebraica. O texto original hebraico é como segue: ${ }^{50}$

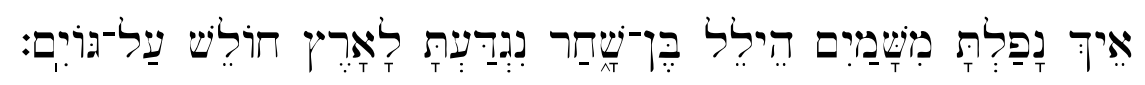

'êy ha nafaltâ mishâmayim hêylêl bem-shâhar nigdda'tâ lâ 'arets hôlesh 'al-gôyim ${ }^{51}$

Uma análise morfológica do texto mostra as seguintes definições:

אִי - partícula interrogativa em forma de interjeição = como?

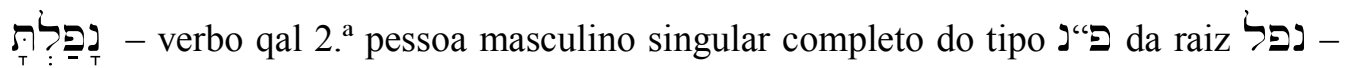
tradução $=$ tu caíste

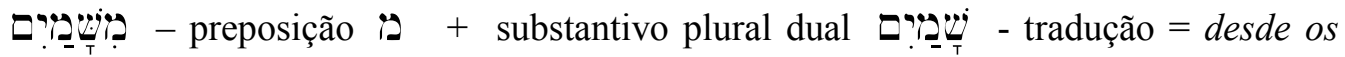

céus, dos céus

- היריל הלי הל substantivo masculino singular absoluto, da raiz - tradução =

\footnotetext{
${ }^{49}$ Chama-se equivalência formal a tradução que procura manter a forma do original o quanto seja possível ao contrário de equivalência dinâmica que se preocupa mais com a língua de destino e menos com a língua de origem.

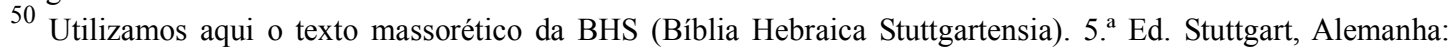
Sociedade Bíblica do Brasil, [2009].

${ }^{51} \mathrm{O}$ hebraico se lê da direita para a esquerda, mas para evitar confusões, a transliteração está da esquerda para a direita.
} 
estrela da manhã, lua crescente, estrela da alva, planeta Vênus, estrela resplandecente.

- substantivo masculino singular construto singular absoluto $\cos _{-}$- tradução = filho da alva, filho do amanhecer

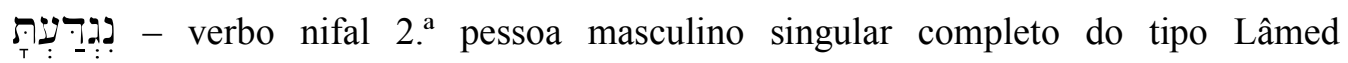
GUTURAL da raiz גדע - tradução = foste quebrado, foste precipitado, foste cortado

- אֶרִ - preposição tradução = para terra, à terra

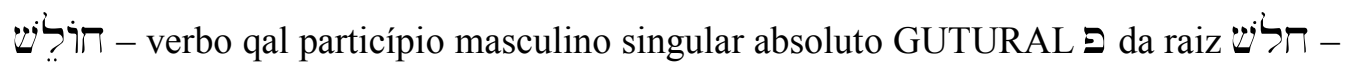
tradução = estava debilitando, debilitavas, enfraquecias

- pַeposição + substantivo masculino plural - tradução = sobre gentios, sobre povos, sobre nações

Abaixo propomos uma tradução Interlinear:

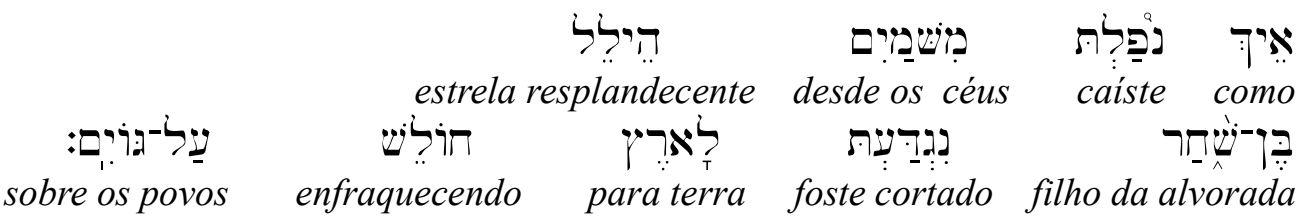

Uma tradução idiomática ${ }^{52}$ do texto pode ser feita da seguinte forma:

Como caiste dos céus estrela resplandecente, filho da alvorada, como foste cortado em direção à terra tu que enfraquecias os povos?

\subsubsection{A ocorrência da palavra lucifer na Vulgata Latina}

\section{Is $\mathbf{1 4 . 1 2}$}

quomodo cecidisti de caelo lucifer ${ }^{53}$ qui mane oriebaris corruisti in terram qui vulnerabas gentes

\footnotetext{
${ }^{52}$ Se chama tradução idiomática uma tradução que faça sentido na língua destino.

53 Os negritos são nossos, assim como o negrito colocado em todas as outras versões citadas.
} 
Como caiste do céu, ó astro brilhante, que, ao nascer do dia, brilhavas? Como caíste por terra, tu que ferias as nações? ${ }^{54}$

\section{Pe 1.19}

et habemus firmiorem propheticum sermonem cui bene facitis adtendentes quasi lucernae lucenti in caliginoso loco donec dies inlucescat et lucifer oriatur in cordibus vestris

Temos ainda a palavra mais firme dos profetas, à qual fazeis bem em prestar atenção, como a uma lucerna ${ }^{55}$ que alumia num lugar escuro, até que venha o dia, e a estrela da manh $\tilde{\boldsymbol{a}}^{56}$ nasça em vossos corações.

\section{Jó 11.17}

et quasi meridianus fulgor consurget tibi ad vesperam et cum te consumptum putaveris orieris ut lucifer

Levantar-se-á pela tarde sobre ti uma luz como a do meio-dia; / e, quando te julgares destruído, surgirás como a estrela da manha.$^{57}$

\section{Sl 109.3 [110.3 na Bíblia Protestante]}

tecum principium in die virtutis tuae in splendoribus sanctorum ex utero ante luciferum genui te

Contigo está o principado no dia da tua força, / entre os resplendores dos santos; / das minhas entranhas te gerei antes da aurora. ${ }^{58}$

\section{Jó 38:32}

numquid producis luciferum in tempore suo et vesperum super filios terrae consurgere facis.

És tu porventura que fazes aparecer a seu tempo a estrela da manhã, / e fazes nascer o Véspero sobre os filhos da terra?

\footnotetext{
${ }^{54}$ Usei aqui a tradução de SOARES, Pe. Matos. Bíblia Sagrada. X Ed. São Paulo: Edições Paulinas, 1982, que é uma tradução feita a partir da Vulgata.

55 Pequena luz.

${ }^{56}$ Ninguém ousaria traduzir essa passagem “...até que venha o dia, e Lúcifer nasça em vossos corações”.

${ }^{57}$ Aqui também ninguém arriscaria a tradução “...surgirás como Lúcifer.”

${ }^{58}$ Não teria sentido manter aqui, por exemplo, o substantivo declinado, pois a tradução ficaria sem sentido.
} 


\subsubsection{Definição do termo latino}

Quicherat (2000, p. 690b) nos dá as seguintes definições do termo latino lucifer:

lucifer $\sim$ era $\sim$ erum, $a$. [LVX+ -FER

1 luz-brilhante, luz-matutina.

era lâmpada (i.e. brilhante) Acc. Trag. 331; aufert (luna) eram partem glomeraminis LUCR. 5.726; eros.. equos (da Lua) OV. Ep. 11.46; eras.. faces (sc. meteoros) V. FL. 5.370; - (como um título de Diana) apud Graecos Dianam eamque $\sim$ eram.. in pariendo inuocant CIC. N.D. 2.68; erae.. delubra Dianae V. FL. 7.179; (cf.) in partu.. rogabis, ut tibi ceras adferat illa (sc. Diana) manus OV. Ep. 19.192 .

2 (masc. as sb.) A estrela da manhã; (mitol.) o filho da Aurora e Céfalos, e pai de Ceyx. B (poet., para 'manhã' ou 'dia').

Cum in caelo fulgit propter lunam er PMPON .com.74; stella Veneris, quae $\Phi \omega \sigma \phi o ́ p o s$ Graece er Latine dicitur cum antegreditur solem CIC.N.D. 2.53; dum rota $\sim$ eri prouocet orta diem TIB. I.9.62; praeuius Aurorae er OV. Ep. 17.112; MAN. 1.177; calidum.. refugit $\sim$ er ipse diem LUC. 2.725; PLIN. Nat. 2.36; STAT. Theb. 2.139; - ero genitore satus.. Ceyx OV. Met. 11.271; HYG. Astr. 2.42. b memento uenturum paucis me tibi $\sim$ eris PROP. 2.19.28; non habet officii $\sim$ er omnis idem OV. Fast. 1.46; quae toga libera detur ero pueris, candide Bacche, tuo 3.772; quae.. Gallicus.. usque a $\sim$ erro donec lux occidat audit JUX. 13.158.

Temos então:

lucifer - substantivo masculino singular nominativo (Is 14.12; II Pe 1.19; Jó 11.17) ${ }^{59}$

luciferum - substantivo masculino singular acusativo (Jó 38.32; S1 110.3) ${ }^{60}$

Ao observar as citações acima, se nota a origem do nome Lúcifer, Jerônimo traduziu a expressão hebraica היִ por lucifer, um substantivo latino que significa estrela da manhãa, aurora, astro brilhante, planeta Vênus. No latim não é um nome, caso fosse, teríamos que traduzir em todas as outras passagens citadas como um nome, o que causaria verdadeiras aberrações. Entretanto, por causa da interpretação teológica da passagem de Is 14.12 como se referindo a Satanás, o substantivo latino passou a ser referido como um nome, esta interpretação se tornou tradição, não foi questionada e passou-se a usar Lúcifer como o nome

\footnotetext{
${ }^{59}$ O nominativo é o caso do sujeito, sem indicação de terminação, é a forma em que encontramos uma palavra no dicionário, tanto no grego quanto no latim.

${ }^{60} \mathrm{O}$ acusativo é o caso do objeto direto que nas línguas declináveis como o grego, alemão, latim é formado pelo acréscimo de terminações ao radical da palavra, não alterando o seu significado, mas somente a indicação de sua função sintática na oração.
} 
próprio de Satanás.

\subsubsection{Outras traduções antigas de Is $\mathbf{1 4 . 1 2}$}

\subsubsection{Targum de Jônatas}

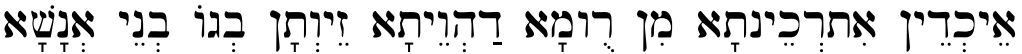

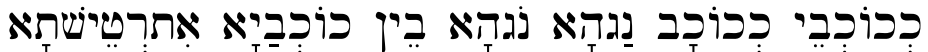

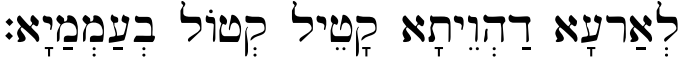

'êykdêyn 'itrekêyntâ' min rumâ' dahwêytâ' zêywetân vegô vnêy 'nâsha'

kekôkvêy khekôvâv naghâ' nôghâ' vêyn kôk kvayâ' 'itretêyshtâ'

le 'ar' $\hat{a}$ ' dahwêytâ' qâtêyl qetôl ve'ammayấ ${ }^{\text {'61 }}$

Como então caiste desde as alturas tu que eras distinto entre os filhos do homem, como estrelas de estrela do amanhecer, do amanhecer entre as estrelas foste banido para a terra que ele decapitou matando os povos. ${ }^{62}$

\subsubsection{Versão Grega (LXX)}

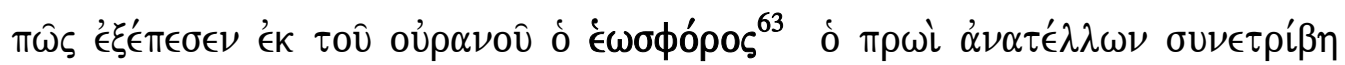

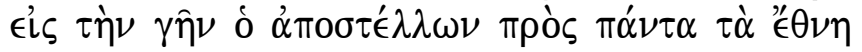

Como caiu do céu a brilhante [estrela] da manhã o que brilha de manhã, ele foi cortado para a terra, aquele que foi enviado para todos os povos.

Estranhamente, uma tradução inglesa da LXX feita por Brenton, traduz a passagem da seguinte forma:

How has Lucifer ${ }^{64}$, that rose in the morning, fallen from heaven! He that sent orders to all the nations is crushed to the earth. ${ }^{65}$

\footnotetext{
${ }^{61} \mathrm{O}$ aramaico também se lê da direita para a esquerda, contudo a transliteração está da esquerda para a direita.

${ }^{62} \mathrm{O}$ Targum traz mais uma interpretação do que uma tradução.

${ }^{63}$ Negritos nossos.

${ }^{64}$ Negritos nossos.

${ }^{65}$ The English Translation of The Septuagint Version of the Old Testament by Sir Lancelot C. L. Brenton, 1844, 1851, published by Samuel Bagster and Sons, London, original ASCII edition Copyright (C) 1988 by FABS
} 


\subsubsection{Outras traduções do texto nas tradições protestantes, católicas e judaicas}

Almeida Corrigida Fiel (1753/1819/1847/1994/1995) Como caíste desde o céu, ó estrela da manhã, filha da alva! Como foste cortado por terra, tu que debilitavas as nações!

Almeida Revista e Corrigida (1969) Como caíste do céu, ó estrela da manhã filha da alva! Como foste lançado por terra, tu que debilitavas as nações!

Almeida Revista e Atualizada (1993) Como caíste do céu, ó estrela da manhã, filho da alva! Como foste lançado por terra, tu que debilitavas as nações!

Sociedade Bíblica de Portugal - tradução em português moderno (2005) Como pudeste cair do céu, astro brilhante da manhã! Foste precipitado por terra, tu, o vencedor das nações!

Almeida Corrigida Fiel (2007) Como caíste desde o céu, ó Lúcifer, filho da alva! Como foste cortado por terra, tu que debilitavas as nações!

Bíblia Sagrada Edições Paulinas (1980) Como caíste desde o céu, ó astro brilhante, que, ao nascer do dia, brilhavas? Como caiste por terra, tu que ferias as nações? ${ }^{66}$

A Bíblia Sagrada (1866) Como cahiste do ceo, ó Lucifer, tu que ao ponto do dia parecias tão brilhante! como cahiste por terra tu, que ferías as nações! ${ }^{67}$

Bíblia Hebraica (2006) Como despencaste do céu, ó estrela da manhã, filho da aurora! Como foi derrubado por terra o que ditava sortes sobre as nações!' 68

Jewish Publishing Society (1917) How art thou fallen from heaven, O day-star, son of the morning! How art thou cut down to the ground, that didst cast lots over the nations!

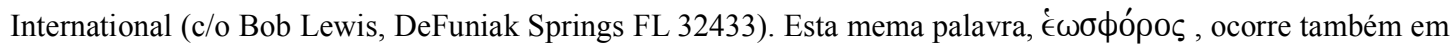
I Sm 30.17; Sl 109.3; Jó 3.9; 11.17; 38.12; 41.10, mas a mesma versão só traduz por lucifer na passagem de Is 14.12, mostrando assim a forte influência teológica na tradução da passagem.

${ }^{66}$ Essa versão foi traduzida a partir da Vulgata pelo Pe. Matos Soares.

${ }^{67}$ Versão também traduzida a partir da Vulgata por Antonio Pereira de Figueiredo.

${ }^{68}$ Versão traduzida por David Gorodovits e Jairo Fridlin, citada aqui para evidenciar de que quando o texto não é sensível para uma determinada comunidade interpretativa há concordância na tradução do termo. 


\section{Jewish Publishing Society (1917) Quoi, tu tombes des ciels, astre, fils de l'aube! Tu es broyé à terre, dompteur des nations! ${ }^{69}$}

Por toda a análise e comparações feitas acima, inferimos que a partir de uma tradição interpretativa que pode ser recuada até a época de Tertuliano, houve interferência nas interpretações posteriores da passagem de Is 14.12, carregando o vocábulo hebraico הִיליל de conotações pejorativas.

Após a versão de Jerônimo, conhecida como Vulgata ${ }^{70}$, ter traduzido esse termo pelo substantivo latino lucifer a tradição interpretativa associada às novas versões como KJV em inglês, Figueiredo (1866), ACF (2007) em português, o que era um substantivo latino se tornou um nome próprio associado ao diabo.

O poder da tradição interpretativa interferiu e continua interferindo nas interpretações e traduções cristãs de Is 14.12. Esse poder de interferência da tradição interpretativa nas traduções não é um fenômeno exclusivo do cristianismo, é possível verificá-lo também em traduções de orientação judaica, como veremos abaixo.

\subsection{Interferência teológica rabínica na tradução de Is $9.5-6{ }^{71}$ ?}

Diferente da necessidade de tradução bíblica com fins de propagação da mensagem cristã, o judaísmo rabínico não se preocupou tanto com a tradução da Bíblia, já que a maior ocupação da tradição judaica foi a interpretação do texto, a tradução bíblica não ocupou lugar central nos meios judaicos. ${ }^{72}$

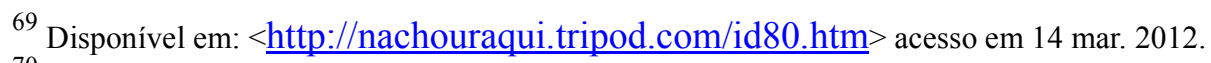

${ }^{70}$ Deve-se lembrar de que a Vulgata assumiu autoridade como versão oficial da tradição cristã até o período da Reforma Protestante do séc. XVI sendo vista como versão "inspirada por Deus" interferindo ainda mais na tradição interpretativa cristã. Após serem feitas traduções protestantes da Bíblia para línguas vernáculas a Vulgata continuou como versão autoritativa somente na tradição católica romana.

${ }^{71}$ A maioria das traduções judaicas seguem a numeração do texto massorético, portanto, o que nas Bíblias protestantes é Is 9.6-7, nas Bíblias Judaicas é Is 9.5-6, a diferença, no entanto, é somente de numeração e não de conteúdo, a versão da Editora Sêfer segue a numeração da Bíblia Cristã, como é informado em Sêfer, 2006, p.8. A Bíblia de Jerusalém (2002), católica, nesse texto é 9.5-6; a Bíblia Sagrada, Edições Paulinas, traduzida pelo Pe. Matos Soares segue a numeração da Vulgata, portanto Is 9.6-7, a LXX tem Is 9.5-6. Estamos utilizando aqui o texto hebraico Westminster Morphology and Lemma Database (WTT) disponibilizado no software Bible Works 7.0, que segue a numeração Is 9.5-6.

72 Para usar o exemplo da língua portuguesa, há diversas traduções da Bíblia de tradição protestante, algumas poucas de tradição católica, contudo, as de tradição judaica são duas, uma inserida juntamente com o texto hebraico que tem somente: a Torá, as cinco Meguilot (Cântico dos Cânticos, Rute, Lamentações, Eclesiastes e Ester) e as Haftarot (porções de outros livros que são lidas ao final da leitura semanal da Torá) (FRIDLIN, 2001), a única versão completa da Bíblia Hebraica de tradição judaica no Brasil é a publicada pela editora Sêfer (FRIDLIN; GORODOVITS. Bíblia Hebraica, 2006).
} 
Tendo em conta que a comunidade judaica foi perdendo o contato com a língua hebraica / aramaica, quando quisesse ler a Bíblia, teria que utilizar-se de versões protestantes ou católicas. Na modernidade, então, surgiram várias edições judaicas do Tanak que incorporaram, em maior ou menor grau, uma tradição interpretativa, principalmente de passagens consideradas mais sensíveis no debate judaico-cristão ligado aos temas messiânicos.

Aqui analisaremos brevemente a interferência dessa tradição interpretativa em algumas dessas edições feitas quer por judeus religiosos, quer por eruditos de origem judaica, que se utilizam das tradições interpretativas do judaísmo rabínico.

O texto fonte que nos chegou é o que segue:

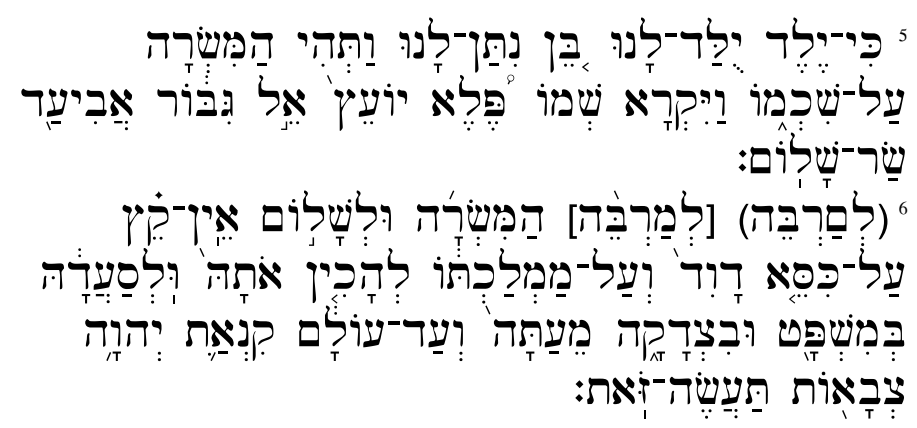

Que podemos traduzir da seguinte forma:

${ }^{5}$ Pois um menino para nós foi gerado, um filho nos foi dado e estará o domínio sobre os seus ombros, Ele se chamará:Maravilhoso Conselheiro, Deus Forte, PaidaEternidade ${ }^{73}$, Príncipe da Paz, ${ }^{6}$ Pela abundância do seu governo e pela paz, não terá fim sobre o trono de Davi, e fará com que o seu reino seja estabelecido e sustentado por meio do juizo e da justiça, desde agora e para sempre, o zelo do Senhor dos Exércitos fará estas coisas.

A já citada versão da Editora Sêfer traz a seguinte versão para o texto:

${ }^{5}$ Pois nasceu entre nós uma criança, um filho (de Ahaz, da dinastia de David) nos
foi dado. E sobre seus ombros estará a autoridade; por isso o maravilhoso
Conselheiro, o Deus Todo-Poderoso e Pai eterno, alcunhou-o (a Hizkiáhu
[Ezequias], o filho de Ahaz) de Sar-Shalom ("Príncipe da Paz"), ${ }^{6}$ para consolidar
seu governo e para que sobre o trono de David e seu reinado não cesse jamais de
haver paz, que será estabelecida e mantida através de justiça e retidão, desde
agora e para todo o sempre. O zelo do Eterno dos Exércitos há de tornar isto
realidade. (SÊFER, 2006, p. 403b-404a)

${ }^{73}$ Preservei a ligação das palavras em português para manter a forma do texto fonte. 
Os tradutores inserem parênteses que funcionam como explicações interpretativas do texto, bem como um colchete para elucidar que $\underline{H i z k i a ́ h u ~ s e ~ r e f e r e ~ a o ~ n o m e ~ j a ́ ~ o c i d e n t a l i z a d o ~ E z e q u i a s, ~ f i l h o ~}$ de Ahaz. Há também várias glosas incorporadas na versão para dar fluência ao sentido que se quer dar ao texto. A versão sofre evidente interferência interpretativa da tradição rabínica que entende o texto como se referindo a Ezequias, a criança nascida como esperança para a nação de Israel. Esta interpretação está presente no Talmud Bavly, que entende Ezequias como o Messias e Senaqueribe como Gogue e Magogue. As passagens do Talmude Bavli que trazem essa interpretação são as seguintes:

do aumento do seu governo e paz não terá fim. R. Tanhum disse: Bar Kappara expôs em Séforis, Por que todo mem final no meio de uma palavra, está aberto, enquanto que aqui nesta passagem está fechado? - O Santíssimo, bendito seja Ele, desejou apontar Ezequias como Messias, e Senaqueribe como Gogue e Magogue; depois do Atributo Justiça disse anteriormente o Santíssimo, bendito seja Ele: 'Soberano do Universo! Se tu não fizeste Davi o Messias, que proferiu tantos salmos e hinos diante de Ti, Tu nomearás Ezequias como tal, que não fez hinos diante de Ti, apesar de todos estes milagres os quais Tu trabalhaste para ele?' Por isso a letra mem está fechada. Imediatamente a terra exclamou: 'Soberano do Universo! Deixe-me proferir canções diante de Ti ao invés deste justo homem [Ezequias], e faça-o Messias. 'Então começou a cantar diante Dele, como está escrito, Das partes mais remotas da terra temos ouvido canções, toda glória ao justo." (Sanhedrin 94a). ${ }^{74}$

R. Johanan disse: Desde os dias de Ezequias, por isso é dito, do aumento do seu governo e paz não terá fim, sobre o trono de Davi, e sobre seu reino, para estabelecê-lo , e mantê-lo com julgamento e com retidão, desde agora e para sempre. O zelo do Senhor dos Exércitos fará isso. (Shabbath 55a) ${ }^{75}$

Rashi também traz a mesma interpretação sobre o texto, ou seja, a tradição interpretativa do texto como se referindo à Ezequias pode ser facilmente verificada nos principais comentaristas medievais do judaísmo rabínico. ${ }^{76}$

Nem todas as versões judaicas mostram essa presença da tradição interpretativa, a JPS, tradicional versão inglesa feita pela comunidade judaica, traz a seguinte tradução do texto:

${ }^{6}$ (9-5) For a child is born unto us, a son is given unto us; and the government is upon his shoulder; and his name is called Pele-joez-el-gibbor-Abi-ad-sar-shalom; ${ }^{7}$ (9-6) That the government may be increased, and of peace there be no end, upon the throne of David, and upon his kingdom, to establish it, and to uphold it through

\footnotetext{
${ }^{74}$ Traduzido da versão inglesa de Soncino, disponível em:

$<$ http://come-and-hear.com/sanhedrin/sanhedrin 94.htmll>, acesso em: 14 mar. 2012.

75 Traduzido da versão inglessa de Sonicno disponível em: <http://come-and-hear.com/shabbath/shabbath 55.html>, acesso em: 14 mar. 2012.

76 De acordo com o comentário de Rashi: קרא שמו של מזקיהו שר שלום כי שלום ואמת יהיה ביומיו

“...chamará o seu nome, de Ezequias, Sar Shalom, pois paz e verdade estariam nos seus dias” In: Miqraoth Gdoloth (Bíblia Rabínica), disponível em: <http://www.hebrewbooks.org>, acesso em: 14 mar. 2012.
} 
justice and through righteousness from henceforth even for ever. The zeal of the LORD of hosts doth perform this. (JPS, 1917)

Exceto pela transliteração "Pele-joez-el-gibbor-Abi-sar-shalom" e as maiúsculas para o tetragrama, não há nessa versão presença de tradição interpretativa como na versão da Editora Sêfer exposta acima.

A versão de Chouraqui traz somente a tradição de cantilação massorética para a divisão de seu texto, contudo, não mostra interferência da tradição interpretativa em seu texto, conforme vemos abaixo:

5. Oui, un enfant est enfanté pour nous, un fils nous est donné.

Et c'est l'autorité sur son épaule.

Il crie son nom: "Merveilleux conseiller, héros d'Él,

père pour toujours, prince de la paix »,

6. pour multiplier l'autorité, pour la paix sans fin

a sur le trône de David et sur son royaume,

pour l'affermir et le restaurer par le jugement et la justification,

désormais et en pérennité.

L'ardeur de IHVH-Adonaï Sebaot fera cela. (Chouraqui Bible ${ }^{78}$ )

5. Sim, um nascimento de uma criança para nós, um filho nos é dado.

E a autoridade está em seu ombro.

Ele grita seu nome: «Maravilhoso conselheiro; herói de El, pai para sempre,

Príncipe da paz»,

6. Por multiplicar a autoridade, pela paz sem fim

estava no trono de Davi e no seu reino,

para fortalecer e restaurar o julgamento e a justificação,

agora e para sempre.

O Ardor de IHVH-Adonai Sebaot fará isso.

\subsection{Interferência teológica na Tradução do Novo Mundo das Escrituras Sagradas}

(Testemunhas de Jeová)

Texto fonte da BH:

\footnotetext{
77 Tradução:

${ }^{6}$ (9-5) Pois uma criança é nascida para nós, um filho nos é dado; e o governo está sobre seus ombros; e seu nome é chamado Pele-joez-el-gibbor-Abi-ad-sar-shalom; ${ }^{7}$ (9-6) Cujo governo poderá ser aumentado, e a paz não terá fim, sobre o trono de David, e sobre seu reino, para estabelecê-lo, e por meio da justiça e pela retidão desde agora e para sempre. O zelo do SENHOR dos exércitos executará isso.

${ }^{78}$ Disponível em: < http://nachouraqui.tripod.com/id91.htm> acesso em 14 mar. 2012.
} 


\section{Gn 1.2}

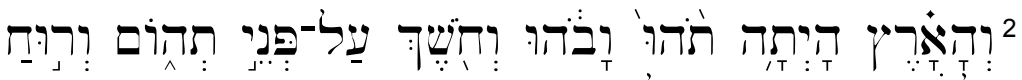

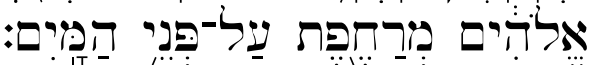

${ }^{2}$ Ora, a terra mostrava ser sem forma e vazia, e havia escuridão sobre a superficie da água de profundeza; e a força ativa de Deus ${ }^{79}$ movia-se por cima da superficie das águas. ${ }^{80}$

Outras traduções do texto hebraico trazem:

ACF (1995) E a terra era sem forma e vazia; e havia trevas sobre a face do abismo; e o Espírito de Deus se movia sobre a face das águas.

${ }^{\text {ARA }}$ A terra, porém, estava sem forma e vazia; havia trevas sobre a face do abismo, e o Espírito de Deus pairava por sobre as águas.

${ }^{\mathrm{KJV}}$ And the earth was without form, and void; and darkness was upon the face of the deep. And the Spirit of God moved upon the face of the waters. ${ }^{81}$

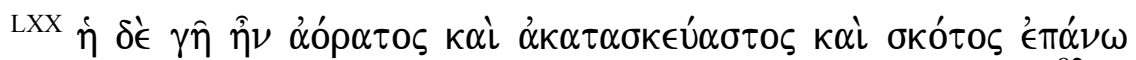

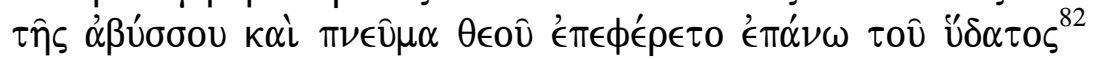

${ }^{\mathrm{VUL}}$ terra autem erat inanis et vacua et tenebrae super faciem abyssi et spiritus Dei ferebatur super aquas ${ }^{83}$

A tradução da expressão hebraica רוּח אֶלה (ruah'elohiim) por força ativa ${ }^{84}$ de Deus tem motivos teológicos. O grupo sectário conhecido como Testemunhas de Jeová surgiu como grupo que rompeu com o Cristianismo Protestante por discordar de várias doutrinas clássicas

\footnotetext{
${ }^{79}$ Negritos nossos.

${ }^{80}$ Disponível em: $<$ http://www.watchtower.org/t/biblia/ge/chapter 001.htm> acesso em: 19 jun. 2012.

${ }^{81}$ E a terra era sem forma, e vazia; e trevas havia sobre a face do abismo. E o Espírito de Deus movia-se sobre a face das águas.

${ }^{82}$ A terra porém era invisivel e sem forma e trevas [havia] sobre o abismo e espirito de Deus [era] conduzido sobre as águas.

${ }^{83}$ E a terra era sem forma e vazia, e havia trevas sobre a face do abismo e o Espirito de Deus pairava sobre as águas. A palavra hebraica ruah tem vários sentidos, tais como: vento, sopro, espírito, brisa, mente (DITAT 2131), a
tradução por força ativa é exclusiva da TNM.
} 
como a trindade, o inferno, a divindade de Jesus, alma humana, dentre outras.

Segundo a doutrina desse grupo, o espírito santo é uma força ativa, e não uma pessoa, conforme lemos:

Na Bíblia, o espirito santo de Deus é identificado como sendo o poder de Deus em ação. Por isso, uma tradução exata do texto hebraico da Bíblia menciona o espirito de Deus como "a força ativa de Deus. ${ }^{85}$

Por discordarem da doutrina católica e protestante, traduzem a expressão hebraica

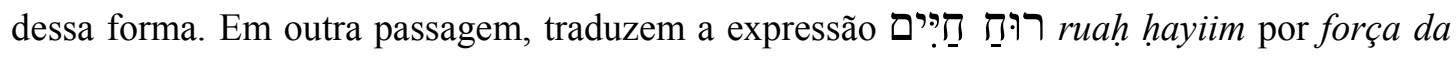
vida ativa, conforme vemos no texto abaixo, em comparação com o texto fonte da Bíblia Hebraica:

Gn 7.15

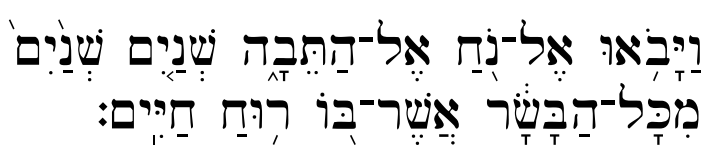

TNM:

E eles continuaram a vir a Noé para dentro da arca, de dois em dois, de toda sorte de carne em que a força da vida estava ativa. ${ }^{86}$

Outras traduções dessa passagem:

${ }^{\mathrm{ACF}}{ }^{(1995)}$ E de toda a carne, em que havia espirito de vida, entraram de dois em dois para junto de Noé na arca.

${ }^{\mathrm{ARA}}$ De toda carne, em que havia fôlego de vida, entraram de dois em dois para Noé na arca;

${ }_{\mathrm{KJV}}$ And they went in unto Noah into the ark, two and two of all flesh, wherein is the breath of life. ${ }^{87}$

\footnotetext{
${ }^{85}$ Disponível em: $<$ http://www.watchtower.org/t/200607a/article 01.htm $>$ acesso em: 16 jul. 2012.

${ }^{86}$ Disponivel em: $<$ http://www.watchtower.org/t/biblia/ge/chapter 007.htm $>$ acesso em: 16 jul. 2012, negritos nossos.

${ }^{87}$ E entraram com Noé na arca, dois e dois de toda carne, nos quais estava o sopro de vida.
} 


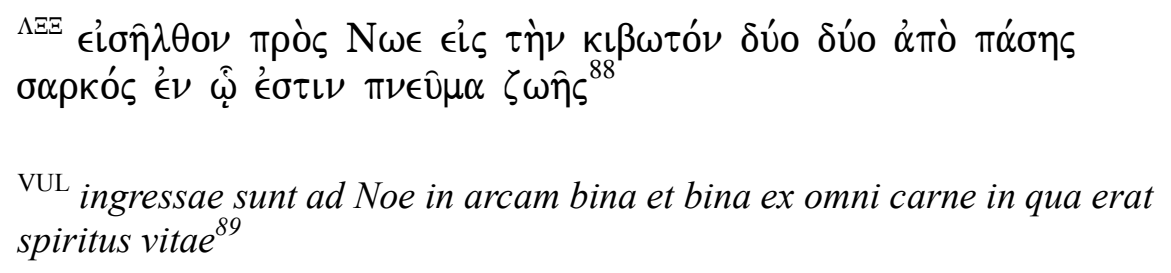

Silva (2007) faz uma análise de várias passagens em que esse grupo insere suas doutrinas em sua versão da Bíblia, tanto na tradução do texto da Bíblia Hebraica quanto no Novo Testamento Grego. Notamos o quanto uma visão teológica interfere na tradução do texto da Bíblia Hebraica de forma que a tradição interpretativa de determinado grupo procura fundamentar sua teologia incorporando-a em suas traduções do texto fonte.

Por meio de uma breve análise das três tradições acima expostas, a cristã protestante, a cristã católica, a dos testemunhas de Jeová e a judaica, podemos perceber a interferência da teologia na tradução de textos sensíveis da Bíblia Hebraica. Essas interferências da tradição interpretativa não começaram com as versões modernas da Bíblia Hebraica, fazem parte de uma longa tradição que pode ser verificada desde as primeiras versões, feitas em diferentes épocas e por diferentes tradições religiosas, o que será exposto nos tópicos seguintes.

\footnotetext{
${ }^{88}$ Entraram com Noé na arca dois e dois de toda carne na qual está o espirito de vida.

${ }^{89}$ E entraram com Noé na arca dois e dois de toda carne na qual estava o espírito de vida.
} 


\section{Tradução ou paráfrase?}

No assunto como um todo, achei que seria adequado me mover entre os dois extremos da paráfrase e da tradução literal; manter meu autor tão próximo quanto possível. Sem perder todos os seus encantos, dos quais o mais eminente está na beleza de suas palavras; e aquelas palavras, devo acrescentar, são sempre figurativas. Aquelas que reteriam sua elegância em nossa língua, eu me empenhei por transportá-las; mas muitas delas devem ser abandonadas, porque não irão brilhar a não ser em si mesmas.

(...)

Ainda assim posso ousar dizer (...) que, tomando todo o material deste divino autor, eu tentei fazer Virgílio falar em inglês como teria falado, tivera ele nascido na Inglaterra, e nesta nossa época (DRYDEN apud STEINER, 2005, 278)

De acordo com Steiner (2005, p. 276-279), Dryden buscou o equilíbrio entre a tradução mais literal proposta por teólogos e gramáticos e as traduções que expressavam uma liberdade exagerada, o que ele chama de "fogosas idiossincrasias" (Steiner, 2005, p. 276). Esse equilíbrio buscado por Dryden tornou a paráfrase a sua prática preferida, para ele essa prática era a maneira pela qual o tradutor poderia trabalhar com liberdade na transposição das ideias de seu autor fonte, de modo a transfundi-lo para outra língua sem fazer com que ele se perdesse na tradução.

Sobre a prática de Dryden, Steiner (2005, p. 278) faz o seguinte relato:

O verdadeiro caminho para o tradutor não está nem na metáfrase $e^{90}$ nem na imitatio. Está na paráfrase ${ }^{91}$ 'ou tradução com liberdade, na qual o autor é deixado à vista pelo tradutor, de modo a nunca ser perdido, mas suas palavras não são seguidas estritamente como o seu sentido, podendo também este ser alargado, mas não alterado'. Este, nos diz Dryden, é o método adotado por Edmund Waller e Sidney Godolphin na sua tradução de 1658 do Livro IV da Eneida. O que mais importa é o método que o próprio Dryden seguiu em suas numerosas traduções de Virgílio, Horácio, Ovídio, Juvenal, Chaucer; e que expôs em sua crítica (notavelmente no Prefácio a Sylvae, de 1685). Por meio da paráfrase 'o espírito de um autor pode ser transfundido e ainda assim não perdido'. A tradução adequada é 'uma espécie de desenho posterior à vida'. Idealmente, ela não vai se apropriar do original, mas nos deixará ver o que o original teria sido tivesse ele sido concebido na nossa própria língua.

No debate entre as teorias da tradução, desde a antiguidade aos nossos dias, na

\footnotetext{
90 Também conhecida como tradução interlinear, tipo de tradução muito frequente em estudos teológicos para pesquisas das línguas originais da Bíblia (grego, hebraico e aramaico), em que uma tradução palavra por palavra é colocada imediatamente abaixo do texto fonte, de forma que o estudante possa verificar a fraseologia da língua de origem na língua alvo.

${ }^{91}$ Todos os itálicos são do próprio Steiner.
} 
polaridade entre a literalidade e a tradução livre, a paráfrase vai além, colocando-se como o fim máximo da liberdade do tradutor, que ao invés de estar subserviente à obra original, pode, agora, se tornar, também ele, um autor por meio da libertação proporcionada pela paráfrase.

A paráfrase se torna um alargamento do autor original, nem tão literal nem tão livre, um equilíbrio, um caminho do meio, uma expansão do texto fonte sem distorção nem alteração.

Nida, ao discutir o que seria uma boa e uma má tradução informa que o termo paráfrase é utilizado como sinônimo de perda e distorção da mensagem original em “...padrões culturais estranhos" (Nida, 1982, p. 173). De acordo com Nida, o sentido correto de paráfrase está ligado à sua teoria da equivalência dinâmica em que "uma boa tradução foca o significado ou o conteúdo como tal e pretende preservá-lo intacto; e, no processo, este pode muito radicalmente reestruturar a forma: isto é paráfrase no sentido próprio." (Nida, 1982, p. 173). Por essa citação, podemos entender que Nida concordava com um tipo de tradução parafraseada, mas afirma que a concepção de paráfrase é compreendida de forma equivocada e que o sentido correto de paráfrase seria o mesmo que o seu paradigma de equivalência dinâmica.

Alguns ramos da teologia protestante não aceitariam uma Bíblia traduzida por meio do paradigma da paráfrase, o que para essas correntes seria uma distorção do sentido do autor original inspirado. ${ }^{92} \mathrm{O}$ texto deve seguir o original o mais próximo possível, inclusive imitando a "forma" do original e não só a tradução do sentido. Por esta causa, a teoria de Nida da equivalência dinâmica se tornou sinônimo de heresia nos meios mais radicais do pensamento protestante. Sendo as traduções feitas por esse princípio consideradas como obras diabólicas, ou seja, os meios mais radicais demonizaram a teoria ${ }^{93}$, tratando-a como inimiga número um do "correto" entendimento das Escrituras Sagradas. ${ }^{94}$ Por outro lado, as versões

\footnotetext{
92 Para efeitos de homilia, contudo, os manuais aconselham a elaborar uma paráfrase própria para fins de familiarização com o texto original antes de se preparar a mensagem a ser pregada, Braga (1986, p. 135), por exemplo, afirma: "haverá ocasióes em que parafrasear toda a unidade expositiva nos será de ajuda para descobrir tanto o sujeito como o complemento".

${ }^{93}$ Para a demonização, tanto das traduções como do próprio Nida, ver $<\underline{\text { http: }: / \text { solascriptura- }}$ tt.org/Bibliologia-Traducoes/VersoesModernasDaBiblia-Cloud-Livro.htm> acesso em: 16 jun. 2013.

94 É interessante notar que o próprio Lutero não apoiava uma tradução literal, em sua produção da tradução da Bíblia para o alemão preferiu maior liberdade na tradução de modo que as Escrituras soassem numa fala mais coloquial do que literal, sobre os princípios de Lutero nos diz Berman (2002, p. 50-51): "Dái a dupla tentativa de Lutero: traduzir para um alemão que a priori só pode ser local, o seu, o Hochdeutsch, mas elevar, no próprio processo da tradução, esse alemão local a um alemão comum, a uma língua franca. Para que esse alemão não se torne por sua vez uma língua separada do povo, deve conservar nele alguma coisa dos Mundarten e dos modos gerais de expressão dos falares populares. Haverá, portanto, o emprego constante e deliberado de uma língua muito oral, carregada de imagens, de locuções, de formas de expressão e, ao mesmo tempo, um trabalho sutil de
} 
que se utilizam do paradigma de Nida da equivalência dinâmica evitam o termo paráfrase, justamente por estar associado à distorção e, assim, teriam pouca aceitação de suas versões nos meios protestantes.

Embora o próprio Jerônimo tenha defendido a ideia de uma tradução sensu sensum, na tradução das Escrituras, entendia que era necessário uma tradução mais literal, pois para ele a Escritura tinha elementos espirituais de inspiração que só poderiam ser preservados por uma tradução mais formal, entendia o texto das Escrituras como um mistério; enquanto traduzia os textos profanos (de forma mais livre), dizia: "Agora e não somente admito, mas livremente anuncio que na tradução do Grego - exceto, é claro, no caso das Escrituras Sagradas - Eu traduzi, não palavra por palavra, mas sentido por sentido." (in: Robinson, 2002, p. 24-25). Essa visão do texto sagrado até mesmo como língua do Espírito Santo, começou a perder sua força no século XIX com a Teologia Liberal Protestante que passou a analisar o texto bíblico com os mesmos princípios que se analisava a literatura profana. Assim, a tradução da Bíblia passou a assimilar as teorias linguísticas utilizadas nos meios acadêmicos seculares.

Ramos mais radicais do judaísmo também preferem traduções menos parafraseadas. Alguns teóricos de origem judaica, tais como Meschonic, Campos e Chouraqui procuram preservar até mesmo a tradição de cantilação massorética em suas traduções do original hebraico. Ou seja, a paráfrase não é bem-vista como via válida de tradução da Bíblia nos meios religiosos. Para Pym (2010, p. 52), "essa recusa geral em permitir adições ou omissões, podem ser encontradas nas proibições bíblicas de modificação do texto sagrado (cf. Deut. 4.2; 12.32; Ap 22.18-19)".

A paráfrase, então, dependendo da linha teórica, pode ser vista como o ideal de tradução, em que o profissional não fica dominado e não é obrigado a servir nem ao texto fonte, nem à língua fonte, pelo contrário, a liberdade do tradutor e a alteração do original é vista como um embelezamento poetizante do original (cf. Berman, 2002, p. ).

Pode-se comparar as teorias a respeito da validade ou não da paráfrase de acordo com as perspectivas teóricas da linguística. Estruturalistas ${ }^{95}$ preferirão traduções menos intrusivas de modo a preservar o texto fonte. Gerativistas ${ }^{96}$ ficarão mais no meio termo, preferindo uma tradução nem tão literal, nem tão parafraseada, já os teóricos do discurso ${ }^{97}$ darão preferência

\footnotetext{
depuração...”.

${ }^{95}$ Comumente associado à obra póstuma de Saussure Curso de Linguística Geral publicada em 1916 e aos seus seguidores.

${ }^{96}$ Os que seguem Avram Noam Chomsky que em seu livro Syntatic Strutures desenvolveu o conceito de gramática gerativa cujos princípios estão presentes na abordagem de Nida sobre tradução.

${ }_{97}$ Duas principais linhas são seguidas pelos teóricos do discurso: 1) a britânica de Norman Fairlough (Discurso
} 
por traduções mais livres, sendo a paráfrase o tipo de tradução mais ideal.

Procurando estabelecer uma diretriz para os limites de uma tradução válida ou aceitável, Beekman e Callow (1992, p. 18) propõem o seguinte quadro:

\begin{tabular}{|c|c|c|c|}
\hline \multicolumn{4}{|c|}{ inaceitáveis } \\
\hline & & & \\
\hline literal demais & literal modificada & idiomática & livre demais \\
\hline
\end{tabular}

Sobre a tradução livre demais, os autores informam, baseados no quadro acima, que é um tipo de tradução inaceitável por ser excessivamente livre, extrapolando o que o texto fonte pretendia dizer "...e como resultado, introduzir na mensagem informações que não se encontram no texto original." (Beekman e Callow (1992, p.20). Os autores estão tratando da tradução da Bíblia e têm por referência os trabalhos de Nida, portanto, a visão que de equivalência formal e dinâmica orientam a abordagem que fazem das teorias de tradução e do julgamento que fazem dos tipos de tradução. Sobre a questão da fidelidade na tradução, lemos, como segue:

(...) a definição de fidelidade focaliza não só o significado, mas também este traço de naturalidade da estrutura lingüística. Em vista destas observações, propomos a seguinte definição de uma tradução fiel: uma tradução que transfere o significado e a dinâmica do texto original. A expressão transferir o significado quer dizer que a tradução comunica ao ouvinte ou leitor a mesma informação que o original comunicou aos seus ouvintes e leitores. (BEEKMAN E CALLOW, 1992, p. 30$)^{98}$

Embora nenhuma tradução afirme ser parafraseada, a inserção de elementos linguísticos, ora explicativos, ora estilísticos, demonstram o uso de paráfrase, principalmente para fundamentar a tradição interpretativa estabelecida. Quanto mais carregada de interferências teológicas ou quanto mais a tradução pretende ser específica para a leitura de um grupo religioso que tem de ler o texto de acordo com aquela tradição interpretativa, mais se fará o uso de elementos parafraseados.

Para notarmos o impacto da paráfrase na tradução da Bíblia, nos próximos tópicos,

e Mudança Social. Brasília: Editora Universidade de Brasília, 2001) e J. Thompson (A Mídia e a Modernidade. Petrópolis, RJ: Vozes, 1998) denominada CDA, Critical Discourse Analysis, no Brasil conhecida como ADC Análise do Discurso Crítica e 2) a francesa de Michel Pêcheux ( $O$ Discurso: estrutura ou acontecimento. Campinas, SP: Pontes Editores, 2008) e Catherine Fuchs, denominada AD Análise do Discurso.

${ }^{98}$ Nota-se pela citação, a concepção gerativista presente também em Nida, mas que não é aceita pelos teóricos discursivos da tradução, tais como Arrojo, Venuti, Aubert, etc. 
veremos alguns casos de traduções que inserem $\operatorname{glosas}^{99}$ de modo a parafrasear o texto fonte em menor ou maior grau nas tradições protestante, católica, judaica e de outras tradições religiosas. Denominaremos como paráfrase qualquer inserção de elementos linguísticos usados para explicar determinadas palavras do texto fonte ou até para interpretar determinadas unidades semânticas da língua fonte para a língua alvo. Para perceber a paráfrase, faremos uma tradução interlinear de acordo com a forma gramatical do hebraico bíblico, a partir do texto fonte, depois, uma tradução idiomática do texto, e, por último, destacaremos em negrito os elementos linguísticos parafraseados inseridos nas traduções analisadas.

Texto fonte da BH com tradução interlinear ${ }^{100}$ :

Salmo 23
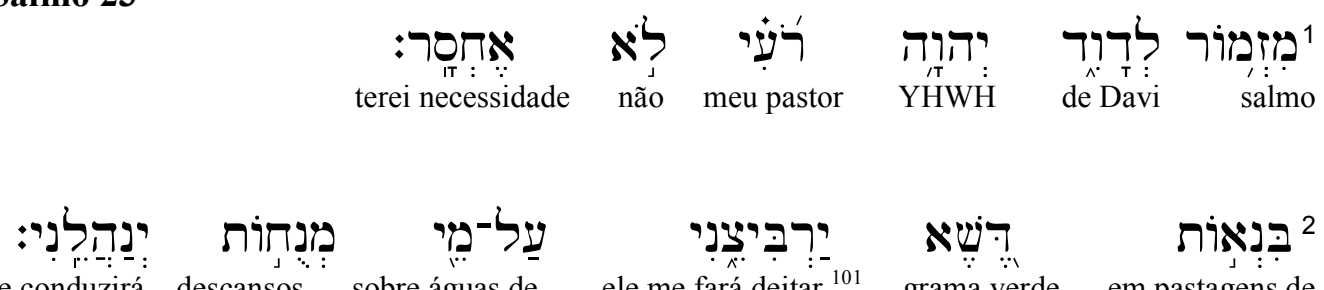

ele me conduzirá descansos sobre águas de ele me fará deitar ${ }^{101}$ grama verde em pastagens de

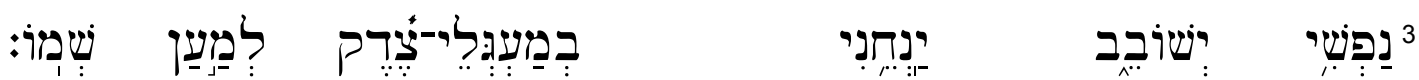
nome dele por causa de em trilhas de retidão ele fará com que eu seja conduzido ele restaurará minha alma
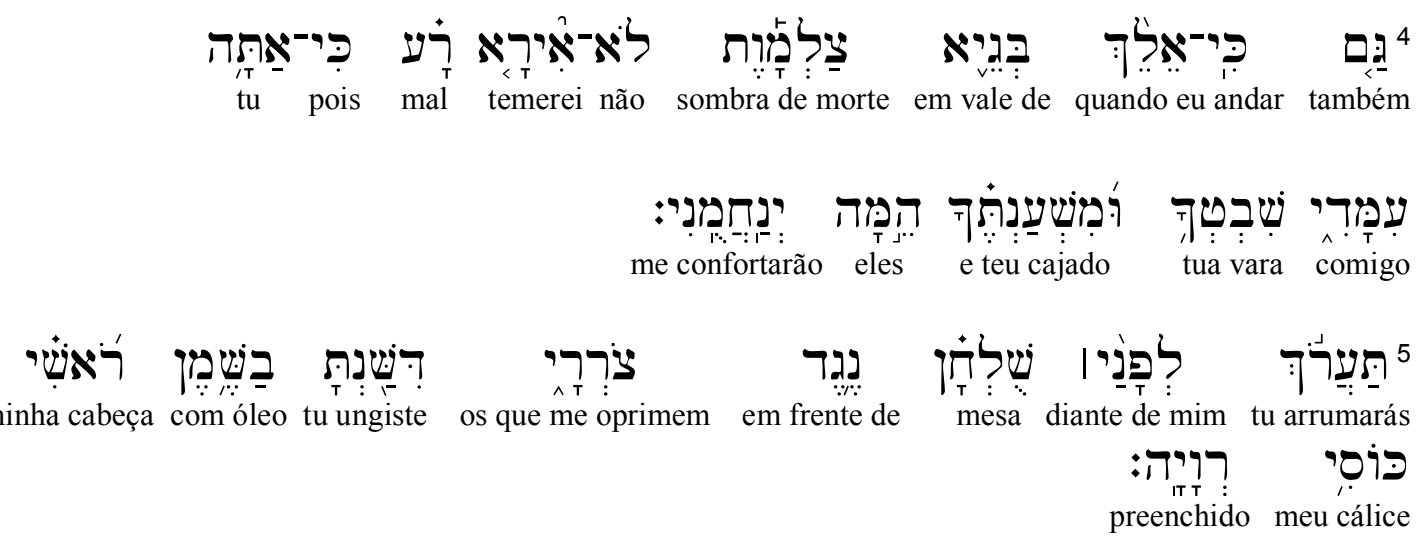

\footnotetext{
${ }^{99}$ Entende-se glosa por palavras adicionadas para dar fluência a um texto ou alguma nota explicativa quer seja interna ao texto quer em rodapé. As notas de rodapé também são conhecidas na teoria da tradução como elementos paratextuais.

${ }^{100}$ Nessa tradução interlinear, daremos ênfase à forma do texto fonte mais do que à sintaxe, que será traduzida mais precisamente na tradução idiomática abaixo.

101 Traduzimos o Hifil com verbos auxiliares para enfatizar a característica causativa dessa forma verbal.
} 


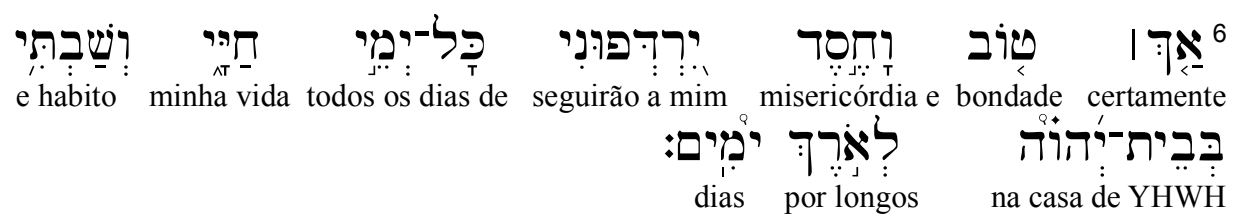

\section{Tradução Idiomática:}

${ }^{1}$ Salmo de Davi. YHWH é meu pastor, não terei necessidade.

${ }^{2}$ Em pastagens de grama verde ele me fará deitar, para águas de descansos ele me conduzirá.

${ }^{3}$ Minha alma ele restaurará, ele fará com que eu seja conduzido em trilhas retas, por causa do seu nome.

${ }^{4}$ Também quando eu andar em um vale de sombra de morte, não temerei mal, pois tu estarás comigo, tua vara e teu cajado, eles me confortarão.

${ }^{5} \mathrm{Tu}$ arrumarás uma mesa diante de mim, em frente dos que me oprimem, tu ungirás com óleo a minha cabeça, meu cálice estará preenchido.

${ }^{6}$ Certamente bondade e misericórdia me seguirão todos os dias de minha vida e habitarei na casa de YHWH por longos dias. ${ }^{102}$

\section{Sociedade Bíblica do Brasil (NTLH, 2000) ${ }^{103}$}

\section{Salmo 23}

${ }^{1}$ O SENHOR é o meu pastor: nada me faltará. ${ }^{104}$

${ }^{2}$ Ele me faz descansar em pastos verdes e me leva a águas tranqüilas. ${ }^{105}$

${ }^{3}$ O SENHOR renova as minhas forças e me guia por caminhos certos, como ele mesmo prometeu.

${ }^{4}$ Ainda que eu ande por um vale escuro como a morte, não terei medo de nada. Pois tu, ó SENHOR Deus, estás comigo; tu me proteges e me diriges.

${ }_{5}^{5}$ Preparas um banquete para mim, onde os meus inimigos me podem ver.

Tu me recebes como convidado de honra e enches o meu copo até derramar.

${ }^{6}$ Certamente a tua bondade e o teu amor ficarão comigo enquanto eu viver. E na tua casa, ó SENHOR, morarei todos os dias da minha vida.

vs.3 renova as minhas forças - é uma interpretação da expressão

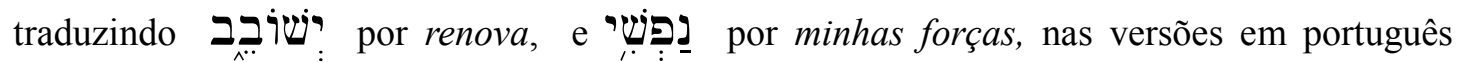

\footnotetext{
${ }^{102}$ Foram traduzidos todos os verbos no futuro do presente no português para concordar com a declaração inicial do texto fonte, em Yiqtol ou conjugação de prefixo (WALTKE; O'CONNOR, 2006).

103 Todos os negritos são nossos.

${ }_{104}$ Aqui a NTLH procura manter a tradução tradicional sem colocar nenhum elemento explicativo.

105 Esse verso também seria aceitável como uma tradução sem inserção de paráfrase, porém, a partir do verso três serão inseridos vários elementos parafraseados.
} 
tradicionais (ARC, ARA, ACF), a expressão é traduzida como refrigera minha alma. A NVI tem: restaura-me o vigor, a $\mathrm{BJ}$ tem restaura minhas forças.

vs.3 como ele mesmo prometeu - aqui a intrusão interpretativa é clara, a paráfrase é utilizada para explicar a expressão (ARC, ARA, ACF) tem sido por amor do seu nome, a BJ tem por causa do seu nome. A $\operatorname{TEV}^{106}$ (1992) traz uma tradução parecida, as he has promised ${ }^{107}$ ), também a NET Bible ${ }^{108}$, tem for the sake of his reputation ${ }^{109}$.

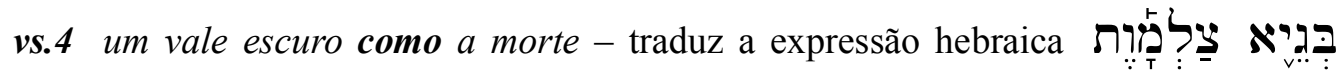
com um símile, seria melhor entender o sentido como de um vale em que [há] uma profunda escuridão.

vs.4 tu me proteges e me diriges - a tradução procura aqui interpretar novamente as

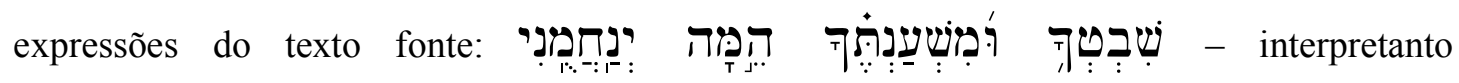

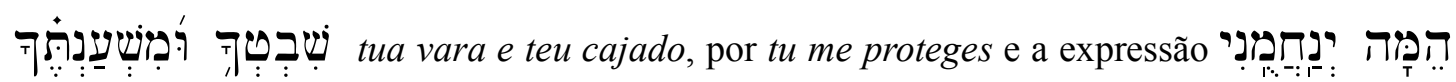
- eles me confortarão por me diriges.

vs.5 Preparas um banquete para mim, onde os meus inimigos me podem ver - nesse verso a tradução da palavra por banquete é uma paráfrase interpretativa e o advérbio português onde foi inserido para se adequar ao estilo da paráfrase; também é evidente

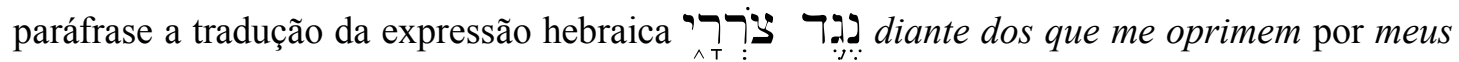
inimigos me podem ver.

\footnotetext{
${ }^{106}$ Essa versão foi feita sob a liderança de Robert Bratcher de acordo com os princípios da equivalência dinâmica de Nida, Bratcher também fez parte da comissão de tradução da BLH da SBB, ver $<$ http://www.nidainstitute.org/eugene-nida-milestones $>$, acesso em: 18 jul. 2012.

107 como ele tem prometido.

108 Disponível em: < https://net.bible.org/\#!bible/Psalms+23> acesso em: 18 jul. 2012, essa versão afirma estar no meio termo entre uma tradução por equivalência formal e equivalência dinâmica, essa tentativa de equilíbrio é descrita no prefácio da edição, disponível em: $<$ http://bible.org/article/preface-net-biblefirst-edition >, acesso em: 18 jul. 2012.

109 por amor à sua reputação.
} 
vs. 5 Tu me recebes como convidado de honra - neste trecho, a paráfrase foi utilizada para

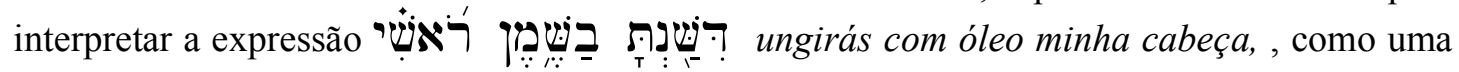

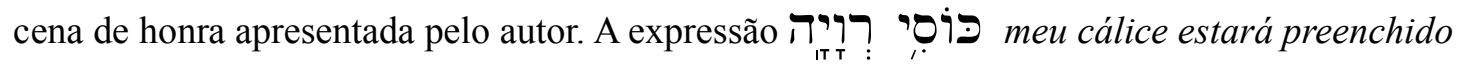
é parafraseada como enches o meu copo até derramar.

vs. 7 todos os dias da minha vida - para traduzir a expressão hebraica

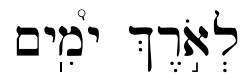
utlizou-se de uma paráfrase explicativa, fazendo relação com a tradução anterior, ficarão comigo enquanto eu viver, propositadamente ou não, manteve-se o paralelismo sinonímico do texto fonte, embora de forma parafraseada.

A versão BLH e NTLH é fiel aos princípios de Nida mesmo na tradução de trechos da poesia hebraica. Procura traduzir mais o significado do que a forma, assim, não se preocupa em transformar um verbo em substantivo, um substantivo num verbo, ou seja, o paradigma da equivalência dinâmica ou funcional quer transmitir o sentido e por isso a forma é secundária nesse paradigma. É o que Nida chama de prioridade da Equivalência Dinâmica sobre a Correspondência Formal. (NIDA; TABER, 1982, p. , 22).

\section{Editora Vida (A Nova Bíblia Viva, 2010) ${ }^{110}$}

Esta versão foi anteriormente publicada em 1981 com o nome de Bíblia Viva e com base nos princípios de tradução da Living Bible, lançada nos Estados Unidos em 1971, declarada explicitamente como uma paráfrase (TAYLOR, Kenneth N.. The Living Bible. Parafraseada. Wheaton, Illinois: Tyndale House Publishers, 1971. Novo Testamento publicado em 1967), para um histórico da versão Living Bible ver: <http://www.bibleresearcher.com/lbp.html> acesso em: 21 jul. 2012. Abaixo veremos o mesmo texto do Salmo 23 e como a versão parafraseou sua tradução.

\section{Salmo 23}

${ }^{1}$ O SENHOR é o meu pastor. Ele me dá tudo o que eu preciso! ${ }^{111}$

\footnotetext{
110 Todos os negritos são nossos.

${ }^{111}$ A Bíblia Viva é uma versão coerente com sua proposta, utiliza-se da paráfrase como uma forma de explicar o texto ao leitor; a NTLH, ao contrário, embora não admita ser uma paráfrase, insere várias palavras explicativas, mas, em algumas instâncias, mantém as formas tradicionais das versões consagradas para não causar estranhamento ao seu público alvo.
} 
${ }^{2}$ Ele me leva aos pastos de grama verde e macia para descansar. Quando sinto sede, ele me leva para os riachos de águas mansas.

${ }^{3}$ Ele me devolve a paz de espírito quando me sinto aflito. Ele me faz andar pelo caminho da justiça por amor do seu nome.

4 Mesmo que eu ande pelo vale escuro, onde a morte está bem perto, continuo tranquilo e não sinto medo, porque a sua vara e o seu cajado me protegem!

5 Prepara um banquete para mim na presença dos meus inimigos. $O$ Senhor me recebe como convidado de honra, ungindo a minha cabeça com óleo, e faz o meu cálice transbordar!

6 Eu tenho absoluta certeza, que a sua bondade e a sua misericórdia me acompanharão todos os dias da minha vida. Sim, eu viverei na presença do SENHOR para sempre!

Vs 1 - me dá tudo o que eu preciso! - paráfrase da expressão $\underset{\pi}{\mathbb{1}}$ : necessidade - claro que a tradução pensa na ideia como uma consequência lógica, se eu não terei necessidade, significa que ele me dá tudo o que eu preciso - contudo, não é tradução , mas explicação. Também, o ponto de exclamação é usado como recurso de ênfase, ausente no texto fonte.

Vs. 2 - pastos de grama verde e macia para descansar - tradução da expressão - em pastagens de grama verde ele me fará deitar - o acréscimo do adjetivo macia constitui um elemento linguístico para enfatizar o descanso da ovelha e, assim, a bondade do SENHOR, contudo não consta da semântica da palavra no texto fonte.

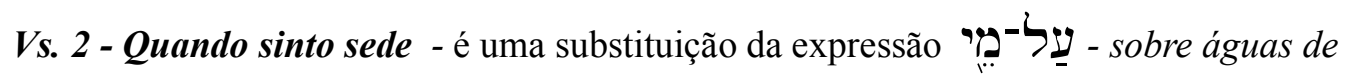
- novamente, na tentativa de explicar mais o sentido do que a forma, contudo, aqui, não é só a questão de forma e sentido, mas os elementos linguísticos parafraseados ${ }^{112}$, que são inseridos, se tornam uma substituição das palavras do texto fonte de forma a tentar explicar o texto mais do que traduzi-lo.

Vs. 3 - Ele me devolve a paz de espírito quando me sinto aflito - uma paráfrase longa

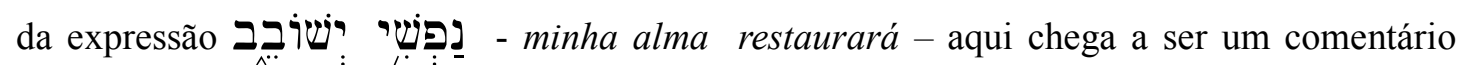
mais do que uma tradução.

\footnotetext{
112 Essa inserção de elementos interpretativos na Living Bible, mãe da Nova Bíblia Viva em português, é criticada até mesmo por Nida e Waard (1986, p. 24-25).
} 


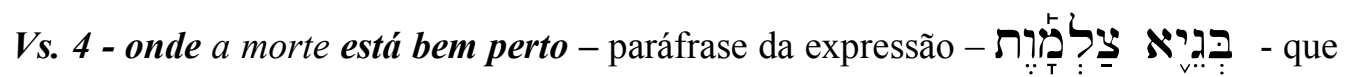
é uma explicação da metáfora da expressão vale de sombra de morte, ou seja, aqui o tradutor interpreta a metáfora como lhe parece.

Vs. 4 - continuo tranquilo e não sinto medo - tradução da expressão hebraica - não temerei mal - omite-se a palavra mal e se acrescentam as palavras continuo tranquilo e sinto, novamente, paráfrases interpretativas do texto fonte.

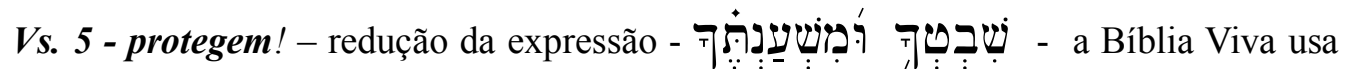
um verbo para explicar a metáfora do pastor que cuida da ovelha com sua vara e cajado.

Vs. 5 - um banquete - redução explicativa da expressão arrumarás diante de mim uma mesa.

Vs. 5 - O Senhor me recebe como convidado de honra - tendo em vista que a Living Bible é anterior à NTLH, não é mera coincidência o empréstimo da NTLH dessa versão ao

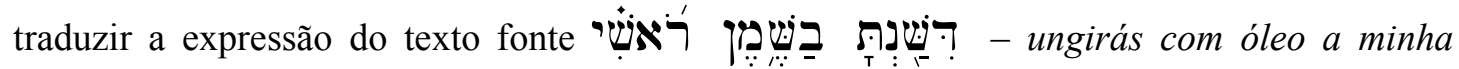
cabeça.

Vs. 6 - Eu tenho absoluta certeza - este é um acréscimo enfático foi inserido para dar mais ênfase do que o texto fonte

Vs. 6 eu viverei na presença do SENHOR para sempre! - as palavras presença e para sempre são paráfrases inseridas para explicar as expressões hebraicas longos dias. O que dá ao salmo conotações escatológicas de vida eterna.

Versões mais antigas tinham maior tendência para a paráfrase, como exemplo, vejamos uma antiga versão católica conhecida como O Pentateuco da Bíblia Medieval 
Portuguesa ${ }^{113}$ (Imago / Educ, 1992, p. 114) traz uma versão bem parafraseada do texto do texto de Êx 20.1-6:

Falou nostro Senhor ao poboo d'Israel em tal guisa ${ }^{114}$, que todos o ouvirom, e esto foi aos cinquenta dias, e entom lhes deu a ley, e disse-lhes em esta guisa: Nom averás Deus alheos ante mym, quer dizer: mym soo averás Deus. Nom farás flagavil $^{115}$, ou ydolo, nem toda semelhança, que he eno ceeo, ou na terra, ou nas augas, ou sô na terra; quer dezer: nom farás a ty por Deus semelhança do sol, ou da lũa, nem d'outras cousas nemhũas, que adoravam desvairados homẽes, que estavam em error, estas cousas nom adorarás, nem honrrarás. E disse mais nostro Senhor por tal que guardasse o poboo esto, que el disse, e al que avia de dizer: Eu som o teu Senhor Deus forte, e zeoso ${ }^{116}$, que vingo os pecados dos padres enos filhos, e ataa a terceira, e a quarta geeraçom daqueles, que me ouverom em ódio, e faço misericórdia ataa mil gerações aaqueles, que me amam.

Este texto não pode nem mesmo ser considerado uma tradução, mas sim uma espécie de comentário medieval com base no texto bíblico, com inserção de vários elementos linguísticos parafraseados do texto fonte ou mesmo de tradição oral decorada, já que o acesso e o conhecimento das línguas fontes da Bíblia Hebraica eram conhecidas por poucos na Idade Média, e mesmo a versão latina não era de fácil acesso.

A paráfrase foi usada na antiguidade para difundir uma determinada interpretação das diversas correntes religiosas com base nos textos da Bíblia Hebraica. Embora, hoje, seja usada de maneira menos intrusiva, ainda é perceptível seu uso, principalmente como uma forma de tornar o texto mais claro para o público alvo da língua receptora, mas, também, para fundamentar a tradição interpretativa das diversas correntes religiosas que têm a Bíblia Hebraica como base de fé e comportamento. Nos próximos tópicos, veremos que esses elementos linguísticos inseridos no texto alvo fazem parte da interferência das tradições religiosas na tradução da Bíblia Hebraica.

\footnotetext{
113 Provavelmente do séc. XIV d.C.

114 Maneira, modo, do germânico wisa (Imago / Educ, 1992, p. 170).

115 Estátua de metal fundido, do latim flagratu = levado ao fogo.

116 zeloso.
} 


\section{Tradução ou Tradição Interpretativa?}

Nenhum outro texto é tão influenciado pela tradição interpretativa como a Bíblia. Como texto sensível de diversas tradições religiosas, a tradução do texto bíblico necessariamente passa pela aprovação, institucionalizada ou não, de um corpus tradicional de interpretação que será uma espécie de controle de qualidade da tradução do texto sagrado, referendando-o ou anatematizando-o antes que chegue aos fiéis ou ao público leigo de determinada corrente religiosa. Traduzir a Bíblia envolve agradar ou desagradar os intérpretes autorizados das tradições interpretativas estabelecidas há séculos, e, portanto, é tarefa árdua e muitas vezes ingrata.

A narrativa de Babel em Gênesis 11 é usada por vários autores ${ }^{117}$ como símbolo orientador da tarefa de tradução. O texto começa informando que: "toda a terra era de uma

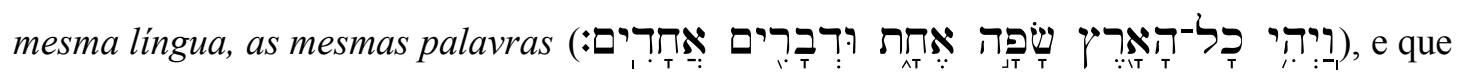

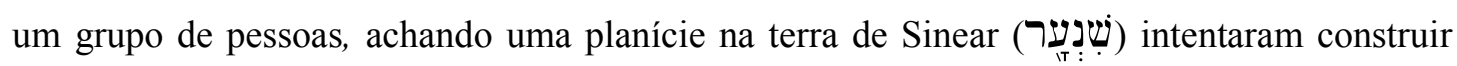
uma grande torre cujo cume chegasse até o céu, para fazerem grande o seu nome. Tal intento não foi agradável ao Senhor que desceu para ver tal construção e confundiu as línguas impedindo que o intento se cumprisse. Assim, as pessoas se espalharam sobre a terra falando diferentes línguas. Por causa da confusão das línguas, o nome da cidade se chamou Babel

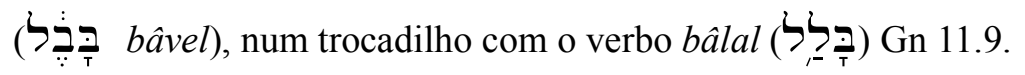

Traduzir seria então um ato de rebeldia contra a ação do Senhor de confundir as línguas, e, por isso, em muitas tradições religiosas, o ato de traduzir tem sido visto como um ato de violação do sagrado, tanto nas tradições religiosas baseadas no texto da Bíblia Hebraica e do Novo Testamento Grego. ${ }^{118}$ Contudo, enquanto no judaísmo tenham sido feitas poucas traduções do texto da Torah e da Tanach ${ }^{119}$, segundo Simon-Shoshan $(2007$, p. 2):

Alguns textos rabínicos vêem a tradução como essencialmente processo sem problemas e não parecem nunca questionar a possibilidade de adequadamente traduzir a Torah em outras línguas. Outras fontes veem a Torah como

\footnotetext{
117 Steiner (1998), Derrida (2002), Şerban (2006), Meschonic (2010a), dentre outros.

${ }^{118}$ Em outras tradições religiosas os textos sagrados tais como o Alcorão e Bagavat Gita (Texto sagrado para o hinduísmo e para outros grupos religiosos de origem hindu tal como os Hare Krishna) foram evitados ou proibidos de serem traduzidos.

119 Posteriormente a visão cabalística sacralizou até mesmo a letras do alfabeto quadrático como emanações da própria divindade e afirmando que por meio dessas letras Deus fez todo universo.
} 
inerentemente intraduzível, e consideram tais tentativas como um escândalo. Conectado a este fato está a questão da acuracidade do texto bíblico recebido e transmitido pelos rabbis relacionado a outras versões da Bíblia. Traduções variadas do texto pode algumas vezes refletir diferentes versões do original. No caso do texto bíblico, esta possibilidade levanta questões urgentes para a teologia rabínica.

No cristianismo, por outro lado, a questão da tradução fazia parte da estratégia de disseminação de suas doutrinas nas mais diversas línguas conhecidas, tanto no mundo antigo como no contemporâneo. Essa diferença de concepção de tradução do sagrado na tradição religiosa cristã pode estar associada ao evento inaugurador da igreja narrado no livro de Atos:

E, cumprindo-se o dia de Pentecostes, estavam todos concordemente no mesmo lugar; ${ }^{2} E$ de repente veio do céu um som, como de um vento veemente e impetuoso, e encheu toda a casa em que estavam assentados. ${ }^{3} E$ foram vistas por eles línguas repartidas, como que de fogo, as quais pousaram sobre cada um deles. ${ }^{4}$ E todos foram cheios do Espirito Santo, e começaram a falar noutras linguas, conforme o Espirito Santo lhes concedia que falassem. ${ }^{5}$ E em Jerusalém estavam habitando judeus, homens religiosos, de todas as nações que estão debaixo do céu. ${ }^{6} E$, quando aquele som ocorreu, ajuntou-se uma multidão, e estava confusa, porque cada um os ouvia falar na sua própria língua. ${ }^{7}$ E todos pasmavame se maravilhavam, dizendo uns aos outros: Pois quê! não são galileus todos esses homens que estão falando? ${ }^{8}$ Como, pois, os ouvimos, cada um, na nossa própria língua em que somos nascidos? ${ }^{9}$ Partos e medos, elamitas e os que habitam na Mesopotâmia, Judéia, Capadócia, Ponto e Ásia, ${ }^{10} E$ Frígia e Panfilia, Egito e partes da Libia, junto a Cirene, e forasteiros romanos, tanto judeus como prosélitos, ${ }^{11}$ Cretenses e árabes, todos nós temos ouvido em nossas próprias línguas falar das grandezas de Deus. (At 2.1-11)

A intertextualidade com Gênesis 11 é inevitável, entretanto, no caso do evento de Pentecostes, ${ }^{120}$ acontece o inverso de Babel, as línguas são unificadas pelo milagre do entendimento de vários povos representados na ocasião que conseguem entender em suas próprias línguas o que está sendo dito.

$\mathrm{Na}$ visão teológica dos cristãos do primeiro século, que perdura até hoje, é como se a maldição de Babel estivesse agora sendo desfeita na inauguração da Igreja. Por isso, a mensagem, em vez de ser deixada no original, deve agora ser espalhada pelo mundo nas mais diversas línguas. Sobre a cosmovisão cristã do evento nos diz Şerban (2006, p. 47):

O Cristianismo, por exemplo, tem adotado como uma maneira fundamental de espalhar sua mensagem pelo mundo (...). Esta tradição cristã de tradução pode ser

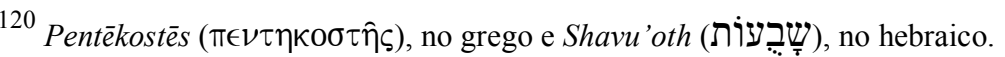


ligada ao evento de Pentecostes, quando, cheios do Espírito Santo, os apóstolos se dirigiram à multidão em várias línguas, não somente Hebraico e Aramaico. Um fundamento para a tradução pode também ser encontrado em São Paulo. Na Primeira Carta aos Coríntios 14.13, São Paulo insta que aqueles que falam uma língua desconhecida que orem para que possam interpretá-la. De acordo com Toker (2005), a visão Paulina é que o espírito, a Verdade, não está ligada aos sons e palavras nas quais as expressões são encontradas, mas que pode ser expressa em diferentes palavras em diferentes línguas.

Posteriormente, o cristianismo sacralizou certas versões e passou a proibir o uso de traduções no vernáculo e a Bíblia Cristã só era utilizada na versão autorizada da Vulgata, essa concepção de sacralidade da Vulgata perdurou até a Reforma Protestante do século XVI, cuja tarefa fundamental foi traduzir a Bíblia para a língua do povo. Por essa razão, a maioria das traduções da Bíblia, em todo o mundo, tiveram origem na concepção protestante de espalhar a mensagem do evangelho nas mais diversas línguas possíveis. Até hoje, as maiores sociedades bíblicas no mundo são protestantes; só recentemente os meios católicos e até judaicos têm procurado produzir versões em língua vernácula de acordo com suas tradições religiosas.

\subsection{O poder da tradição}

A tradição faz parte da formação de cada indivíduo, ninguém, como pessoa constituída pode ser dizer livre de qualquer tradição. Desde escovar os dentes até a maneira de expressões religiosas, o ser humano segue rituais, na maioria das vezes repetidos sem serem refletidos ou percebidos. O que fazemos por tradição e não refletimos, se torna incorporado em nossa cosmovisão, de modo a pensarmos fazer parte da realidade, a essa realidade damos conceituações de verdade e negamos outras realidades que não se encaixem em nossa preconcepção tradicional, assim, fazemos a leitura do mundo ao nosso redor, assim, também, fazemos a leitura de textos, ou seja, ao lermos um determinado texto, trazemos para essa leitura nossa cosmovisão, logo, quanto maiores forem as marcas deixadas pela tradição em nossa cosmovisão, mais carregada será a nossa leitura do mundo e dos textos que tivermos contato.

Embora de forma um tanto quanto exagerada, o desconstrutivismo trouxe à reflexão linguística, a necessidade da análise crítica do texto como portador de intertextualidade inerente, ou seja, a não existência da autonomia de autoria e, sim, da multiplicidade de textos em um determinado autor. Levando a teoria às últimas consequências, quando entendemos a tradução como um elemento de segunda mão, ou seja, em uma tradução não temos o texto 
fonte, e sim uma leitura de segunda via, feita pela imagem que determinado tradutor ou grupo de tradutores tiveram do texto fonte e como transferiram essa imagem ao texto de destino. Se o desconstrutivismo questiona a própria noção de autoria o que dirá sobre a noção de tradução, se não há nem mesmo autor, como haverá tradução?

Em várias áreas do conhecimento humano, podemos dizer que a cosmovisão de algum tipo de tradição interferiu na leitura dos textos e na interpretação dos conceitos, não só no campo da religião, mas também em outros campos da ciência, temos tradições filosóficas, que analisam o mundo pela ótica de um determinado filósofo, podemos falar então de uma visão platônica, aristotélica, nietzschiana. Tradições de interpretação psicológica, assim podemos falar de visão freudiana, junguiana, lacaniana. Tradições políticas tais como marxista, leninista, maoísta, nazista, capitalista.

É comum serem feitas análises de visões religiosas como se somente elas fossem manipuladoras, mas seria ingênuo não entendermos que qualquer concepção que interfira na leitura que fazemos da realidade, seja ela científica ou religiosa, induz-nos a uma leitura condicionada pela tradição que herdamos, quer da religião quer da academia. O mito da imparcialidade há tempos não domina mais o pensamento acadêmico.

Não se pode ignorar a tradição como elemento coativo poderoso e que interfere na leitura tanto do mundo quanto na tradução dos textos da Bíblia Hebraica; tanto o judaísmo rabínico quanto o cristianismo católico têm enfatizado a importância e a necessidade da tradição como órgão oficial, autorizado e único de interpretação do texto sagrado. Embora não tão enfaticamente, e nem sempre assumindo como posição oficial, o protestantismo também tem seus órgãos interpretativos que funcionam como um elemento de interpretação autorizada do texto sagrado. ${ }^{121}$

De acordo com Fishbane (1988, p. 1)

(...) a orientação exegética é também básica para a transformação interna das religiões tradicionais. Significativamente, o Mestre da Justiça de Qumran, e Jesus, e Paulo, e todos os reformadores religiosos que vêm a mente, apresentam-se como autênticos intérpretes das religiões que representam.

Fishbane reconhece a tradição de interpretação como tendo lugar comum no judaísmo tradicional e no cristianismo de linha romana ortodoxa. Esse autor afirma que para essas

\footnotetext{
${ }^{121} \mathrm{O}$ exemplo mais notório é a chamada linha Reformada que se assemelha muito a uma cosmovisão católica de tradição interpretativa, embora nunca admitam, a linha Reformada do Protestantismo, também conhecida como Calvinismo Extremado, não aceita outra interpretação dos textos bíblicos que não sejam as estabelecidas pelo establishment interpretativo de suas tradições.
} 
tradições religiosas “...a revelação é compreensivel somente por meio da tradição autoritativa de interpretação"., exceto o cristianismo protestante, que se opõe a essa visão pelo princípio dos reformadores de sola scriptura (FISHBANE, 1988, p. 2).

No âmbito da tradução da Bíblia, a tradição é o elemento mais significativo na transposição de padrões de leitura estabelecidos. Esses padrões de leitura nem sempre podem ser traçados retroativamente até sua origem, pois se perdem no cruzamento de várias tradições interpretativas diferentes, por vezes opositoras, mas de fontes comuns, omitidas por organizações, autoridades ou comunidades detentoras do poder da tradição, que procuram de várias maneiras, às vezes mais evidentes, às vezes menos visíveis, menosprezar as tradições interpretativas concorrentes do establishment interpretativo. Tendo em vista que poucas pessoas têm acesso ao texto fonte da Bíblia Hebraica nas línguas originais (hebraico, aramaico), um meio eficaz de manipulação e estabelecimento da tradição interpretativa é a tradução, já que a mesma é utilizada como versão autorizada pela comunidade interpretativa ou pela autoridade interpretativa tradicional, sendo assim, versões que divergem da versão ou versões autorizadas são invalidadas e menosprezadas.

O tradutor da Bíblia sempre foi o seu primeiro intérprete, quer validando a posição do establishment interpretativo, e, então, tendo validada a sua obra, quer se opondo a esse establishment e sendo considerado como herege e sua obra considerada como proibida ou imprópria para leitura naquela tradição religiosa.

\subsection{A canonização das versões autorizadas pela tradição}

A canonização de determinadas versões antigas e modernas pode ser vista como consequência lógica do fato da Revelação Divina estar em línguas desconhecidas da comunidade religiosa e a leitura do original ser inacessível ao povo comum. Permitir toda e qualquer tradução seria permitir muitas visões diferentes do texto sagrado, o que comprometeria a continuidade daquela tradição interpretativa.

A história testemunha a canonização ou sacralização de determinadas versões produzidas ou reconhecidas por determinada tradição interpretativa de modo a excluir quaisquer versões concorrentes daquela tradição estabelecida.

Como será visto mais tarde, sobre a versão dos Setenta, as lendas sobre determinadas versões da Bíblia serviram como uma propaganda de determinadas correntes religiosas para validar essas versões e para que as mesmas fossem aceitas e utilizadas pela comunidade 
religiosa como se fossem o próprio original.

Dentre as versões antigas autorizadas e canonizadas pelo judaísmo, temos a LXX e, posteriormente, os Targumim. O meio católico romano canonizou a LXX nos seus primeiros séculos e depois a Vulgata de Jerônimo, permanecendo esta até o Concílio Vaticano II como única versão autorizada pela Igreja Católica Romana. O protestantismo canonizou várias versões, desde a versão de Lutero até, posteriormente, a Bíblia de Genebra, por último, e tendo o status de Versão Autorizada, a King James ou Versão do Rei Tiago (1611), tem sido a que mais tempo permanece no seio protestante como versão canonizada pelo mundo de fala inglesa. $^{122}$

\subsection{Princípios de Interpretação Cristã}

Os princípios de interpretação cristã iniciam com os escritos conhecidos como Novo Testamento, que já indica um pressuposto ${ }^{123}$ dos seguidores de Jesus de Nazaré de que o seu mestre era o messias prometido nas escrituras judaicas e que inaugurava agora a era messiânica, trazendo um Novo Testamento, conforme a promessa profética em Jr 31.31, é nessa perspectiva que os autores do NT entendem a mensagem e ensino de Jesus (cf. 26.28; I Co 11.25; Hb 8.6-9).

Não há consenso entre os estudiosos cristãos sobre os métodos de interpretação utilizados pelos autores do NT. Autores, tais como Osborne (2009), Stern (1989, 2010), Edersheim (1988), Barrera (1998) entendem que os autores utilizaram de métodos de interpretação comuns ao contexto judaico do primeiro século, tais como os targumim e midrashim. Kaiser Jr. (KAISER Jr.; SILVA, 2002, p. 208-210) e Gardiner (1885, p. 317-318) negam que Jesus e os autores neotestamentários tenham usado métodos rabínicos em sua interpretação das passagens Bíblia Hebraica, embora o próprio Kaiser Jr. reconheça que as sete regras de Hilel podem ter feito parte da interpretação Bíblia Hebraica que Jesus fazia em seus ensinos, conforme lemos:

Muitas das sete regras de Hilel aparecem nos ensinamentos de Jesus, pois essas regras normalmente fazem justiça às intenções do autor que escreveu o testamento mais antigo. Ótimos exemplos mostram nosso Senhor fazendo uso dessa prática

\footnotetext{
122 Esta versão comemorou seus 400 anos em 2011 com grande festa e edições especiais feitas pelas Sociedades Bíblicas Inglesas e Americanas, embora seja uma versão de origem Anglicana.

${ }^{123}$ Essa pressuposição de abordagem cristã da Bíblia Hebraica como Antigo Testamento é analisada por Reif. Aspects of the Jewish contribution to biblical interpretation. in: BARTON, John (ed.). The Cambridge companion to Biblical Interpretation. Cambridge, UK: Cambridge University Press, 1998, p.144-145.
} 
podem ser encontrados em Marcos 2.25-28 e João 7.23; 10.34-36. Mas Jesus não nos dá nenhum exemplo de exegese medrash (sic) ou pesher. (KAISER Jr.; SILVA, $2002,208-209)^{124}$

Embora não se possa exagerar a comparação entre o tipo de interpretação judaica dos primeiros séculos e a interpretação cristã, não se pode negar, contudo, que as semelhanças são marcantes. Primeiramente, deve-se entender que o nome cristão foi dado aos seguidores de Jesus posteriormente, conforme lemos no próprio texto de At 11.26: E sucedeu que todo um ano se reuniram naquela igreja e ensinaram muita gente. Em Antioquia, foram os discipulos, pela primeira vez ${ }^{125}$, chamados cristãos ${ }^{126}$. Antes disso e até mesmo durante todo o primeiro século, os cristãos faziam parte de mais um dos muitos grupos judaicos do primeiro século como os fariseus, saduceus, herodianos, dentre outros grupos existentes que partilhavam de uma identidade comum centrada no templo de Jerusalém ${ }^{127}$ e das reuniões na sinagoga ${ }^{128}$, não é estranho, portanto, entender que esses grupos, apesar de suas diferenças partilhavam de fontes textuais comuns e até mesmo de princípios comuns de interpretação.

As parábolas de Jesus assemelham-se, por exemplo, ao tipo conhecido no meio judaico com mashal e nimshal, tanto em vocabulário e temas quanto em método de interpretação. Também, as citações e alusões dos evangelhos se assemelham ao tipo de citação mishnaica agrupando versículos e fazendo alusões a textos da Bíblia Hebraica. O tipo de citação paulina também se assemelha ao tipo de interpretação rabínica. O próprio Paulo afirma ser hebreu de hebreus, fariseu segundo a Lei (Fp 3.5), judeu fervoroso e discípulo de Gamaliel (At 22.1-5; Gl 1.13-14). Sobre a abordagem da pessoa e pensamento paulino, é pertinente observarmos a mudança de visão nos estudos paulinos, como nos informa Martin et al. (2008, p. 953):

Nos últimos anos, houve uma significativa mudança nos estudos paulinos. Durante a primeira metade do século XX, a escola dominante da "história das religiões" enfatizou uma abordagem helenística de Paulo: entendiam que Paulo era um judeu

\footnotetext{
124 Os itálicos são dos autores.

125 Negritos nossos.

${ }^{126}$ no grego Xpıotı®vós cristão, seguidor de Cristo.

127 O grupo de Qumran, geralmente associado com os essênios, apesar de não concordar com a administração do templo tinham também fontes e modelos de interpretação parecidos com os outros grupos judaicos do primeiro século.

${ }^{128} \mathrm{O}$ próprio Jesus ensinava na sinagoga (Mc 6.2) Paulo, em suas viagens missionárias tinha por princípio, primeiramente procurar a sinagoga da cidade na qual estava em missão, só posteriormente a suas pregações na sinagoga é que partia para a pregação entre os gentios, conforme lemos em At 18.4; 19.8, neste último texto somos informados que Paulo discute durante três meses na sinagoga da cidade de Éfeso.
} 
helenizado da diáspora. ${ }^{129}$ Por exemplo, R. Bultmann e seus seguidores concluíram que o judaísmo sincretista da diáspora e a filosofia popular da época constituíam a base do pensamento paulino (...). Hoje em dia porém os estudos neotestamentários encontram cada vez mais indícios das características judaicas da vida e do pensamento de Paulo. Na verdade, essa mudança faz parte de um movimento geral dos estudos cristãos para redescobrir as raízes judaicas do cristianismo. Simultaneamente, os estudos judaicos demonstram crescente interesse em recuperar as características judaicas de Jesus e de Paulo.

O apocalipse também tem sido comparado ao tipo de interpretação midráshica, embora os estudos a respeito dessas semelhanças interpretativas e intertextualidade com os tipos rabínicos de interpretação ainda não serem conclusivas. ${ }^{130}$

Por meio da análise interna do próprio texto neotestamentário e dos estudos históricos e sociológicos do ambiente em que viveram os escritores do NT, verifica-se a herança judaica comum desses autores, no uso que faziam Bíblia Hebraica como fonte principal e de métodos e fontes comuns ao judaísmo do segundo templo, Osborne resume a importância de se entender esse ambiente para se entender o NT da seguinte forma:

É impossível exagerar a importância de se entender o uso do AT para a pesquisa do NT. Cada estrato da igreja primitiva - cada tradição, cada autor no NT - foi imerso no AT, e sua teologia está baseada nele. Ao mesmo tempo, cada aspecto das tradições do NT, conforme visto na segunda metade deste capítulo, utiliza o AT de maneiras um pouco diferentes. Mas há uma coisa que todas têm em comum: a abordagem que herdaram, a apropriação judaica das narrativas e passagens do AT dentro dos estratos do judaísmo do Segundo Templo. A exegese midráshica, a tipologia e os padrões do pesher foram utilizados pelos autores do NT e permeiam as páginas do NT. Assim, quando estudamos as citações ou alusões, devemos olhar para todos os níveis: o contexto do AT do qual elas se originaram, a teologia e as técnicas judaicas na apropriação do texto ou narrativa particular, e o uso explícito da passagem no contexto do Novo Testamento. (OSBORNE, 2009, p. 439)

Depois de 70 d.C., os grupos judaicos desaparecerão, restando basicamente os cristãos e fariseus, que dos dois lados começaram a fazer questão de se diferenciarem, afastando-se, então, de sua origem comum de fontes de tradição, exceto no caso das escrituras da Bíblia Hebraica, mas que mesmo assim se tornou um elemento de tradição diferenciado, tendo em vista que os cristãos tiveram preferência pelo uso da versão grega da Bíblia Hebraica, enquanto que os fariseus se fixaram no uso da Bíblia em hebraico ou adaptaram para si versões gregas com suas visões particulares de interpretação, por exemplo, a versão

\footnotetext{
${ }^{129}$ Vermes (1996, p. 95-108) também discorda de um judaísmo helenístico para os escritos do NT e confirma fontes judaicas comuns do primeiro século.

${ }^{130}$ Uma breve discussão sobre esse tema é abordado em Osborne (2009, p. 436-437).
} 
ultraliteral de Áquila que surgiu como uma versão apologética contra o uso cristão da LXX. A tradição interpretativa em uso nos escritos neotestamentários envolve o uso abrangente de todos os livros Bíblia Hebraica ${ }^{131}$, Kaiser Jr. faz uma breve análise desse uso com as seguintes palavras:

Há 224 citações diretas do Antigo Testamento dentro do Novo Testamento, sendo que cada uma é introduzida por uma expressão típica. Em sete outros casos elas são introduzidas pela palavra "e"; dezenove casos de paráfrases ou sumários do Antigo Testamento parecem depender de citações e 43 casos de clara semelhança indicam que esses textos também dependem do Antigo Testamento. Não há unanimidade sobre o número exato de alusões ao Antigo Testamento dentro do Novo: C. H. Toy contou 613, Wilhelm Ditmar argumentou que eram 1.640, enquanto Eugene Huehn pensou ter encontrado 4.105! O importante é que os escritores do Novo Testamento dialogavam com o Antigo Testamento e sentiam que estavam diretamente ligados a ele. (KAISER Jr; SILVA, 2002, p. 208).

O debate sobre o uso da LXX no NT ainda é ardente entre os estudiosos do NT. Para Simian-Yofre et al. (2000, p. 62), as citações Bíblia Hebraica no NT não são literais e há divergências nessas citações, que, segundo esses autores, poderiam ser devido a motivos teológicos ou citações de memória. ${ }^{132}$ Mais detalhes sobre essa versão serão dados nos tópicos referentes às versões abaixo.

O fim do I século e início do segundo é denominado de período ante-niceno que vai desde o ano 100 até 325 d.C. O fim do período apostólico se dá com a morte do último apóstolo, João, por volta do ano 100 e o último escrito neotestamentário considerado apostólico, o apocalipse, por volta de 95 d.C.

O fim do século I e início do século II testemunhará obras de grande importância para a compreensão da história da interpretação cristã, obras como I e II Clemente (100 d.C.), Pseudo-Barnabé (100 d.C.) Policarpo aos Filipenses (110-140 d.C.) Diálogo com Trifão (c. 155 d.C.) de Justino de Roma, são textos representantes da interpretação cristão formadora da

\footnotetext{
${ }^{131}$ Uma lista detalhada desse uso pode ser verificada na edição do NT grego da UBS 4. ${ }^{\text {a }}$ ed. 2008 (SBB / Deutsche Bibelgesellschaft), p. 745-748, onde são listadas as citações diretas do AT no NT, tanto observando a ordem dos livros do AT quanto observando a ordem dos livros do NT, nas p. 749-760 são mostradas as alusões e paralelos verbais do AT usados no NT, observando a ordem dos livros do AT, também são alistadas alusões a livros apócrifos e até alusões a autores gregos. Stern (2011) também coloca em negrito todas as citações ou alusões ao texto do AT em sua tradução da sua Bíblia Judaica Completa, embora faça também um índice das citações nas p. 1608-165, segundo esse autor (p. 1608): "Existem 484 passagens do Tanakh citadas 695 vezes na B'rit Hadashah da Bíblia Judaica Completa".

${ }^{132} \mathrm{O}$ texto da UBS 4 ed., coloca a sigla LXX quando a citação corresponde à Septuaginta, também coloca negritos no texto grego para destacar as citações diretas da LXX, contudo, pode-se encontrar também nessa lista, citações do AT que se assemelham ao texto de Teodocião e não da LXX, como por exemplo, Mt 24.6, que faz alusão a Dn $2.28,29 ; 2.45$.
} 
tradição interpretativa que se perpetuou na Igreja Cristã até a Reforma Protestante do século XV.

O método de interpretação cristã da Bíblia Hebraica nesse período pode ser vista no seguinte exemplo extraído da Epístola de Barnabé 9.8: ${ }^{133}$

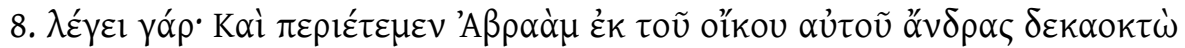

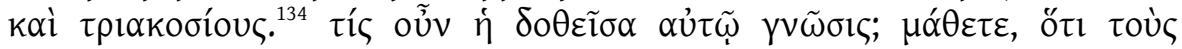

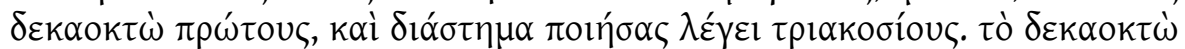

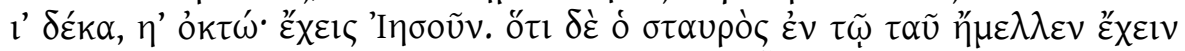

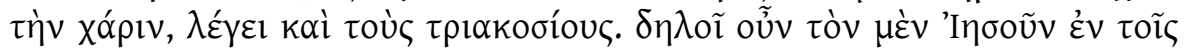

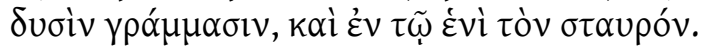

Pois diz: e circuncidou Abraão, de sua casa trezentos e dezoito homens. Qual é então o conhecimento ${ }^{135}$ que há nisto? Aprendei, porque o número dezoito vem primeiro, e tendo feito um intervalo diz trezentos. $O$ dezoito $I=$ dez, $H=$ oito! Tens Jesus [IH $\Sigma O Y \Sigma]$. E também a cruz no Tau $[T]^{136} e ́$ sobre ter a graça, diz também os trezentos. Assim então Ele revelou Jesus nas duas letras, e na outra a cruz. ${ }^{137}$

Esta interpretação se assemelha ao método de interpretação Gematria ${ }^{138}$ ou נטריקון (notariqon), em que cada letra corresponde a inicial de uma palavra hebraica, encontrando sentidos ocultos no texto. ${ }^{139}$ Outro método de usar partes de letras da Bíblia Hebraica para proceder interpretações é chamado תמורה (temurah = troca) ou הפוך (hipuk = inversão). Contudo, aqui, a Epístola de Barnabé, em vez de se utilizar do texto hebraico, utiliza-se da versão grega para fazer sua interpretação. Ainda nesse período, dentre os autores que se destacam por seus métodos de interpretação e profícuo uso Bíblia Hebraica com um

\footnotetext{
${ }^{133}$ Texto grego extraído de LAKE, Kirsopp. Apostolic Fathers in Greek. Grand Rapids, MI: Christian Classics Ethereal Library, 1913. Disponível em: <http://www.ccel.org/ccel/lake/fathers2.html> acesso em: 15 ago. 2012, tradução nossa.

${ }^{134}$ A citação é dupla de Gn 14.14 com Gn 17.23, citações de duas passagens unidas como se fosse um só texto são comuns tanto no NT quanto nas citações rabínicas.

${ }^{135}$ Deve notar-se o uso aqui do termo gnōsis ( $\left.\gamma \vee \tilde{\omega} \sigma l \varsigma\right)$ com um sentido de conhecimento oculto ou misterioso, ver abaixo visão de Clemente de Roma sobre gnossis.

${ }^{136}$ Aqui é destaca a aparência da letra Tau, que como o nosso T parece uma cruz esse simbolismo do aspecto das letras também é utilizado pelo misticismo judaico, o qual interpreta a aparência das letras hebraica para encontrar sentidos ocultos no texto da Bíblia Hebraica.

${ }^{137}$ A epístola é considerada por Farrar (1886, p. 167) “Intensamente antijudaica no seu tom, diretamente judaica em seu método, é marcada por uma teoria incoerente e ininteligivel."

${ }^{138}$ Ver Sanhedrin $22^{\mathrm{a}}$.

139 Irineu utiliza também desse método para dizer que Jesus, em hebraico ישוע , utilizando as iniciais, conclui

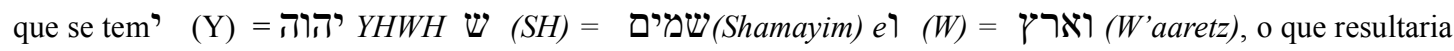
em Senhor dos Céus e da Terra.
} 
grande número de citações, temos Clemente de Roma, para esse autor, a interpretação das escrituras do Antigo Testamento depende do dom do conhecimento, ou gnose ( $\gamma v \omega$ бIs), "Ele e seus leitores e todos os Cristãos, presume-se, compartilham deste dom, a habilidade para descobrir a vontade do Senhor para a Igreja Cristã no ensino do Antigo Testamento" (Gilbert, 1908, p. 88). Essa tradição está fundamentada na visão dos escritos neotestamentários, mas é levada ao extremo pelos pais da Igreja tornando a Bíblia Hebraica um livro cristão de apoio às suas doutrinas, esse paradigma orientará a tradição interpretativa cristã e influenciará na produção de várias versões da Bíblia Hebraica durante a história da tradução. De acordo com Clemente, a Bíblia Hebraica não é um livro judaico, mas um livro cristão, uma profecia segundo a qual Cristo fala à Igreja.

Outro grande expoente do tipo de interpretação cristã do segundo século é Justino de Roma (100-165 d.C.), no diálogo ${ }^{140}$ com o judeu Trifão ${ }^{141}$ percebe-se já um distanciamento das origens judaicas do cristianismo, tanto que, no debate, a premissa comum inicia-se com questionamentos filosóficos ${ }^{142}$ e, depois, centra-se nas escrituras da Bíblia Hebraica, comum a ambas as tradições. No diálogo (11.5) nota-se o entendimento cristão já presente no NT de que os crentes em Jesus constituíam o novo e verdadeiro Israel ${ }^{143}$, pois seguiam as pisadas de Abraão e estavam ligados a ele como "descendentes" pela fé e não pela circuncisão ou por nascimento carnal. ${ }^{144}$ Pelo fato de Justino e muitos outros pais da Igreja terem vindo do mundo helenístico e serem filósofos em sua maior parte, sua hermenêutica e exegese serão influenciada pelos princípios filosóficos de sua época ${ }^{145}$, portanto, afastando-se ainda mais da origem judaica do cristianismo que tinha uma exegese mais próxima à exegese do judaísmo pré 70 .

Outros textos e autores desempenharão papel importante na fundamentação da

\footnotetext{
${ }^{140}$ O diálogo foi escrito por volta de 155 d.C. de acordo com Frangiotti (in: Justino, Mártir, Santo Justino de Roma: I e II Apologias: Diálogo com Trifão. São Paulo: Paulus, 1995, p. 107): "Esta obra representa a controvérsia mais antiga entre o cristianismo e o judaísmo. Constitui-se, portanto, no primeiro documento de valor, fora do Novo Testamento, sobre as relações controvertidas do cristianismo com o judaísmo".

${ }^{141}$ Pelo diálogo nota-se que Trifão é um judeu helenizado que diz ser judeu circuncidado, fugido da guerra (Bar Kochba 132-135 d.C.) vive na Grécia e passa a maior parte do tempo em Corinto (Diálogo com Trifão 1.3).

142 Diálogo com Trifão 1.3-6.

143 Rm 4.11-13; Rm 9.7; Mt 3.9; embora os escritores do NT ainda façam distinção a um Israel carnal, o distinguem do Israel espiritual, principalmente Paulo que diz que o novo Israel é constituído de todos os crentes da nova aliança, quer judeus, quer gentios (Rm 9.1-33).

144 Enquanto o Talmud associa a posteridade de Isaque à descendência carnal (Sanhedrin 59b), o Midrash Gênesis Rabbah (53.12) associa a descendência de Isaque a todos os que creem no mundo vindouro. Segundo Martin et al. (2008, p. 955-956) essa interpretação é semelhante a que Paulo faz ao discorrer sobre Gn 21.12 em Rm 9.6-29.

${ }^{145}$ Essa influência também ocorre no judaísmo, principalmente com Filo de Alexandria (20 a.C - 45 d.C.), que é fruto de um judaísmo helenístico e influenciou grande parte dos cristãos alexandrinos no tipo de interpretação do AT.
} 
tradição interpretativa cristã, mas três grandes escolas de pensamento cristão serão as grandes orientadoras da tradição interpretativa da Igreja, são elas as Escolas de Alexandria, de Antioquia da Síria e a Escola do Ocidente.

A Escola de Alexandria ${ }^{146}$ tem como seu primeiro e grande mestre Titus Flavius Clemente, mais comumente conhecido como Clemente de Alexandria (150-215 d.C.), de acordo com Kaiser Jr. e Silva (2002, p. 210):

Clemente adotou o método alegórico de Philo ${ }^{147}$ e propôs o princípio de que as Escrituras devem ser compreendidas alegoricamente. Ele argumentou que "por muitos motivos, as Escrituras escondem o sentido... sendo pois que os mistérios sagrados das profecias estão ocultos em parábolas' (Miscellanies 6.15). Em outra parte de sua obra ele ensinou que 'quase todas as Escrituras são expressas em forma de enigmas' (Stromata 6124.5-6 (sic! $\left.{ }^{148}\right)$ ).

O princípio de interpretação alegórica ${ }^{149}$, que procurava utilizar o Antigo Testamento de forma simbólica e tipológica como sombras de acontecimentos da vida e obra de Cristo e da vida e ministério da Igreja Cristã, dominou o pensamento da Escola Alexandrina. Embora Clemente de Alexandria tenha sido o mestre e iniciador da escola, um discípulo seu o irá superar em todos os aspectos, o nome desse discípulo de Clemente é Orígenes (185-253 d.C.), considerado o pai do método alegórico de interpretação das Escrituras. É de Orígenes o primeiro tratado técnico de hermenêutica cristã (Kaiser Jr. e Silva, 2002, p. 211), sobre Orígenes, nos diz Berkhof (2008, p. 20):

Orígenes considerava a Bíblia como um meio para a salvação do homem; porque, de acordo com Platão, o homem consiste em três partes - corpo, alma e espírito ele aceitava um sentido tríplice, a saber, o literal, o moral e o místico ou alegórico. ${ }^{150} \mathrm{Na}$ sua práxis exegética, preferia desconsiderar o sentido literal da Escritura, referia-se raramente ao sentido moral e usava constantemente a alegoria - uma vez que só ela produziria o conhecimento real.

Orígenes rejeitou o significado literal e adotou a posição de que este significado

\footnotetext{
${ }^{146}$ Para Barrera (1998, p. 528), o judeu Filo foi o precursor da Escola de Alexandria.

147 De acordo com Berkhof (2008, p. 20), Clemente de Alexandria foi o primeiro dos pais da Igreja a adotar o método alegórico para interpretar tanto o Antigo quanto o Novo Testamento.

148 Stromata e Micellanies são a mesma obra.

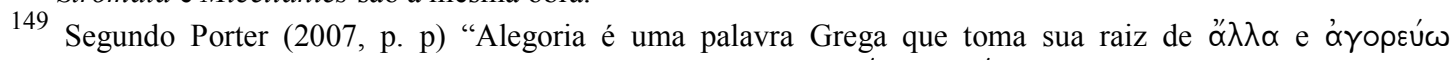
(literalmente): falar outras coisas; em um sentido técnico $\alpha ́ \lambda \lambda \eta \gamma о \rho \varepsilon ́ \omega$ significa: falar ou interpretar alegoricamente".

${ }^{150}$ Falava também de uma interpretação espiritual contrapondo-se a uma interpretação histórica (De Principi 3.3, in: SCHAFF, Philip. Nicene ande Post-Nicene Fathers. New York: The Christian Literature Company, 18901900, Origen, De Principi, Cap. III, p. 252).
} 
deveria ser utilizado somente por cristãos iniciantes que não fossem capazes de entender o significado alegórico, metafórico ou simbólico das Escrituras. Ele entendia que nem todas as passagens da Bíblia Hebraica tinham um significado literal, mas que todas tinham um significado espiritual. "Orígenes declara que sem o método alegórico é fácil cometer incontáveis erros de interpretação" (BARRERA,1998, p. 530). O método alegórico foi usado como uma ferramenta apologética contra uma interpretação literalista das Escrituras, principalmente o tipo de interpretação halaǩh, feita pelo judaísmo farisaico. Entretanto, seguindo o princípio de Filo, o método alegórico da Escola de Alexandria e de Orígenes, usava o método também para explicar alegadas contradições no texto da Bíblia Hebraica, assim nos informa Vanhoozer (2005, p. 137):

Por exemplo, Orígenes não conseguia imaginar de que maneira três "dias" se passaram antes da criação do Sol e da Lua. Muito menos conseguia entender que se recontassem as momices de Noé ébrio. Para Orígenes, o significado literal é quase sempre lugar-comum; é o significado que apenas os mais simples entre os leitores vêem no texto. Ele compara a leitura literal do texto a comer o cordeiro pascal cru. Pode-se tirar mais alimento espiritual das histórias bíblicas quando elas são lidas alegoricamente. Por exemplo, a história de Rebeca tirando água do poço e encontrando o servo de Abraão aponta para a verdade mais profunda de que precisamos visitar todos os dias os poços da Escritura a fim de encontrarmos Cristo.

A segunda escola de pensamento e interpretação cristã de grande impacto foi a Escola de Antioquia da Síria ${ }^{151}$. Desde o primeiro século d.C. a cidade é conhecida pela forte presença judaica, dos cerca de 300.000 habitantes nessa época, estima-se que havia entre 22.000 e 65.000 judeus habitando na cidade (Martin et alli, 2008, p. 92). É conhecido o fato narrado no NT de que a cidade foi um grande centro de pensadores cristãos e de difusão da mensagem do evangelho. Barnabé foi o primeiro líder cristão enviado à cidade para ensinar os novos crentes e, depois, o próprio Paulo foi conduzido à cidade para ajudar Barnabé nessa tarefa (At 11.22-24). Nas páginas do NT, lemos que a igreja se tornou centro missionário de onde saíam líderes para a divulgação do evangelho e depois retornavam para prestar um tipo de relatório das missões empreendidas pelo mundo Romano (At 13.1-4; 15.35; 18.22).

Esta centralidade da cidade na história da igreja cristã mostra a razão de posteriormente ter surgido uma escola de pensamento e interpretação. A Escola desenvolveuse na cidade por volta do século IV e início do século V d.C. A Escola de Antioquia também recebeu influência do pensamento judaico, nas palavras de Barrera:

${ }^{151}$ A cidade também chamada de Antioquia do Orontes. 
A comunidade Judaica desta cidade era muito influente, como tinha sido no passado. Os Antioqueanos eram opositores à exegese alegórica como desenvolvida por Filo e os Cristãos de Alexandria. Ao invés disso, eles colocavam ênfase na natureza histórica da revelação bíblica a qual não deveria ser quebrada por símbolos e alegorias. O temperamento intelectual dos Antioqueanos foi mais Aristotélico do que Platônico. (1998, p. 530).

Entre os expoentes mais ilustres dessa escola está Teodoro de Mopsuéstia (350-428), que não era um estudioso do hebraico e, como muitos pais da igreja, via versão grega LXX como inspirada, rejeitando até mesmo a versão Síria chamada Peshitta. Por causa da visão dos pais da igreja de que os apóstolos utilizara a LXX, Teodoro pensava sempre que a Peshitta estava errada e a LXX sempre estava certa ${ }^{152}$. Teodoro de Mopsuéstia, conforme Farrar (1886, p. 215), "Apesar de rejeitar o método alegórico de Orígenes, aprendeu com ele a importância de prestar atenção a detalhes linguísticos especialmente ao comentar o Novo Testamento."

Para Teodoro era preciso se ater ao todo de uma passagem e não a partes isoladas de um determinado texto, prestava atenção à sequência de pensamento, examinava a fraseologia do texto separando cada cláusula, só após ter feito toda essa divisão de pensamento é que Teodoro fornecia a exegese "a qual é frequentemente de característica brilhante e profundamente sugestiva” (Farrar, 1886, p. 215). ${ }^{153}$

A terceira escola de interpretação que exerceu grande influência na tradição interpretativa cristã foi a Escola Ocidental. Essa escola de pensamento cristão adotava tanto o método alegórico da Escola de Alexandria quanto os princípios mais literais da Escola de Antioquia. Um elemento novo, entretanto, é colocado pela Escola Ocidental de Interpretação, sobre esta Escola de Interpretação observa Berkhof (2008, p 21):

Um tipo intermediário de exegese surgiu no Ocidente. Ele abrigava alguns elementos da escola alegórica de Alexandria, mas também reconhecia alguns dos princípios da escola Siríaca. Seu aspecto mais característico, no entanto, encontrase no fato de ter promovido outro elemento, o qual não tinha se feito valer até aquele tempo, a saber, a autoridade da tradição e da Igreja na interpretação da Bíblia. Era atribuído ao ensino da Igreja no campo da exegese um valor normativo. $^{154}$

Teremos então, pela primeira vez na história da interpretação cristã, a força da tradição

\footnotetext{
152 vide Farrar (1886, p. 213-214, notas 5-6).

${ }^{153}$ De acordo com Virkler (2007, p. 46) o fim da Escola de Antioquia da Síria deu-se pelo fato de um discípulo de Teodoro, chamado de Nestório, ter se envolvido em uma heresia referente a pessoa de Cristo e, por isso, a escola ficou associada a Nestório encerrou suas atividades.

${ }^{154}$ Itálicos do autor.
} 
interpretativa e da autoridade da igreja como norteadora do entendimento dos textos da Escritura. Os principais nomes da Escola Ocidental de Interpretação também são os grandes pensadores da igreja em várias outras áreas que não a exegese. Dentre os nomes que se destacam na Escola estão: Hilário de Poitiers ${ }^{155}$ (ca. 300 - 368 d.C.), Ambrósio (340 - 397) e os tão conhecidos Agostinho de Hipona (354-430) e Jerônimo (347-420). Nos concentraremos nos dois mais importantes: Agostinho e Jerônimo.

A obra mais significativa de Agostinho como um modelo interpretação cristã da Bíblia é a obra denominada Doutrina Christiana ${ }^{156}$, obra onde o autor expõe com detalhes quais devem ser os procedimentos hermenêuticos para se interpretar as Escrituras do ponto de vista cristão. Essa e outras obras de Agostinho foram de crucial importãncia para o pensamento cristão de modo a produzir uma tradição interpretativa que só irá ser suplantada posteriormente com as obras de Tomás de Aquino.

O prólogo da Doutrina Christiana é uma refutação prévia a todos os que quiserem se opor aos métodos expostos por Agostino na obra. Essa refutação prévia começa com as seguintes palavras:

\begin{abstract}
Antes de iniciar, contudo, parece-me que devo responder aos que contestarão, ou talvez venham a contestar, este meu esforço, caso não os convença antecipadamente. Se esta exposição não for suficiente para que alguns cessem as críticas, pelo menos fará com que não demovam nem afastem outros de estudo tão proveitoso. Poderiam ser estes levados a desânimo paralisante, se não estivessem premunidos e preparados. (Doutrina Christiana, Prólogo 1)
\end{abstract}

Ele refuta previamente três possíveis contestadores: os que não entenderão as normas ensinadas pelo autor; os que entenderão, mas quererão aplicar imediatamente o conhecimento adquirido e, não conseguido explicar algumas passagens das Escrituras, pensarão ser o trabalho do autor inútil e, por último, os que "interpretam bem" ou "imaginam interpretar bem" e pensam ser as normas expostas por Agostinho inúteis, pois as dificuldades das Escrituras só podem ser interpretadas pela oração “...e consistem em puro dom divino." (Doutrina Christiana 2).

Berkhof diz mais sobre os princípios de interpretação de Agostinho:

Agostinho diferenciava-se de Jerônimo pelo fato de seu conhecimento das línguas originais ser bem deficiente. Isso equivale a dizer que ele não foi, principalmente, um exegeta. Ele foi grande em sitematizar as verdades da Bíblia, mas não na

\footnotetext{
155 Também chamado de Santo Hilário.

${ }^{156}$ Publicada em português com o nome de A Doutrina Cristã: Manual de Exegese e formação cristã.
} 
interpretação da Escritura. Seus princípios hermenêuticos, os quais trabalhou em seu De Doctrina Christiana, eram melhores que sua exegese. Ele advogava que um intérprete deveria ser filológica, crítica e historicamente equipado para sua tarefa e, acima de tudo, que tivesse amor pelo seu autor. Enfatizou a necessidade de se ter consideração pelo sentido literal e de basear o alegórico sobre ele; mas, ao mesmo tempo, entregou-se livremente à interpretação alegórica. $(2008$, p. 21)

Agostinho fazia uso abundante da Bíblia em seus escritos, uma análise feita por Lagarde, um estudioso da Universidade de Göttingen, na Alemanha contou 42.816 citações da Bíblia nas obras agostinianas, 13.276 citações da Bíblia Hebraica e 29.540 do Novo Testamento (Fragiotti, 2002, p. 21, in: A Doutrina Cristã). Quanto ao sentido das Escrituras, Agostinho entendia um sentido quádruplo para o texto bíblico:

histórico, etiológico (uma investigação acerca das origens e causas), analógico e alegórico. O conjunto de quatro termos que acabaram sendo aceitos pela escola ocidental de hermenêutica era composto pelo sentido literal, alegórico, tropológico (moral) e anagógico (místico ou escatológico). A ilustração usual desse sentido quádruplo surgiu por volta de 420 d.C. nas Conferências (14.8) de João Cassiano: Jerusalém literalmente significa a cidade dos judeus; alegoricamente Jerusalém é a igreja (S1 46.4, 5); tropologicamente, Jerusalém é a alma (S1 147.1, 2, 12); e anagogicamente, Jerusalém é nosso lar celestial (Gl 4.26). Cassiano deixou claro que o sentido quádruplo não se encaixava em todas as passagens das Escrituras; devia-se sempre dar atenção primeiramente ao sentido literal, conforme enfatizado pela escola de Antioquia. Mas os sentidos analógico e alegórico mantinham vivas as preocupações centrais da escola de Alexandria com os aspectos místicos e espirituais do texto, enquanto o tropológico permitia que moralistas judeus e cristãos descobrissem os ensinamentos morais e éticos do texto. (KAISER Jr. e SILVA, 2002, p. 214) ${ }^{157}$

Como já dito, o outro pensador mais significativo na Escola Ocidental de interpretação foi Jerônimo. Ao contrário de Agostinho, era profundo conhecedor do hebraico e do grego e é também conhecido pela famosa tradução que produziu, a Vulgata. Contudo, Jerônimo não foi um sistematizador como Agostinho, sua exegese está mais vinculada a uma prática de interpretação e tradução da Bíblia do que numa formulação de princípios hermenêuticos. Não foi um profundo e genial teólogo e filósofo como Agostinho, seus estudos estavam mais voltados para a linguística e sua prática exegética é de longe mais apurada do que seus antecessores e, mais ainda, do que seus sucessores.

Jerônimo deu grande valor às autoridades judaicas e, mesmo a despeito de grande oposição, preferia as Escrituras Hebraicas à versão grega da LXX, que já em seu tempo havia

${ }^{157}$ Todo os itálicos são do autor. 
conquistado status de inspirada e, por isso, ao preferir fazer a sua tradução diretamente do hebraico, conquistou muitos inimigos. Estudou com rabinos no tempo que morou em Israel e aconselhava consultá-los em caso de dúvidas a respeito da Bíblia Hebraica. ${ }^{158}$ Para Farrar (1886, p. 224), o conhecimento que Jerônimo tinha da língua hebraica foi provavelmente maior do que qualquer outro pai da igreja. Sua influência na tradição interpretativa, contudo, será maior no efeito e autoridade que sua tradução causou ao longo da história da interpretação cristã. ${ }^{159}$

O período posterior da interpretação cristã será conhecido como Idade Média, será um período de pouca profundidade e menos ainda de exegetas. Seja pelos grandes vultos do passado da igreja cristã, seja pelo pouco empenho dos escritores, a Idade Média se tornou na igreja cristã, a era da repetição. A tradição interpretativa se tornou realmente tradição, eram considerados grandes escritores e intérpretes os que sabiam repetir o que os grandes intérpretes do passado já tinham dito, a hermenêutica e a exegese se tornaram escravas da tradição. Prevaleceram os princípios de Agostinho sobre o sentido quádruplo das Escrituras e a versão de Jerônimo se tornou canonizada e única fonte de informação sobre a Bíblia, nas palavras de Berkhof (2008, p. 22):

\begin{abstract}
Durante a Idade Média, muitos, até mesmo do clero, viviam em profunda ignorância quanto à Bíblia. E o que conheciam era devido apenas à tradução da Vulgata e aos escritos dos Pais da igreja. A Bíblia era, geralmente, considerada como um livro cheio de mistérios, os quais só poderiam ser entendidos de uma maneira mística, Nesse período, o sentido quádruplo da Escritura (literal, tropológico, alegórico e analógico) era geralmente aceito, e o princípio de que $a$ interpretação da Bíblia tinha de se adaptar à tradição e à doutrina da Igreja tornou-se estabelecido. Reproduzir o ensino dos Pais e descobrir os ensinos da Igreja na Bíblia eram considerados o ápice da sabedoria. A regra de São Benedito foi sabiamente aplicada aos monastérios, e decretado que as Escrituras deveriam ser lidas e, com elas, como explicação final, a exposição dos Pais da Igreja. ${ }^{160}$
\end{abstract}

A máxima latina quod ubique quod semper quod ab omnibus creditum est (Aquilo que em toda parte, que sempre e por todos, tem sido aceito como verdadeiro), frase de São Vicente de Leris ( ${ }^{\dagger} 445$ d.C.), em sua obra Commonitorium 2.3, é ainda aceita como fonte válida para os católicos como manual de ortodoxia. ${ }^{161}$ Esta obra permaneceu na Idade Média

\footnotetext{
158 Vide Barrera (1998, p. 353-354).

${ }^{159}$ Maiores detalhes sobre Jerônimo e sua tradução serão dados abaixo, no tópico referente à Vulgata.

${ }^{160}$ Todos os itálicos são do autor.

161 O Communitorim também está disponível em espanhol em:

http://www.statveritas.com.ar/Libros/COMMONITORIO(San Vicente de Lerins).pdf $>$ acesso
} 
como orientadora contra os hereges que não aceitavam a "fé católica" e tomou conta do pensamento e da interpretação bíblica, validando e orientando a tradição interpretativa da igreja ao dizer que qualquer análise bíblica precisaria ser referendada pela tradição da igreja encontrada nos Pais.

Outras obras que serviram como fonte de validação do discurso religoso do catolicismo medieval foram: Glossa Ordinária de Walafrid Strabo (808-849), Glossa Interlinearis de Anselmo de Laon ( $\left.{ }^{\dagger} 1117\right)$, As Catenae de Procópio de Gaza (c. 465-528) no Oriente e as Catenae de Tomás de Aquino (1225-1274) no Ocidente e o Liber Sententiarum de Pedro Lombardo (1555-1625). ${ }^{162}$ Estas obras acabaram por reforçar a autoridade da Tradição da igreja e a orientar a interpretação das Escrituras, que agora estava fechada e amarrada ao peso da tradição. ${ }^{163}$

Malanga (2005, p. 238) denomina essa posição católica de $O$ "Fechamento" Interpretativo do Catolicismo (ibid., p. 237) e comenta:

Quando falamos sobre a interpretação bíblica no catolicismo, devemos levar em conta que as discussões se restringiam aos círculos intelectuais de filósofos. Existe uma grande distância entre a elite que pensa o discurso da Igreja e os seus fiéis. Os textos não se destinavam à leitura dos fiéis comuns, mas à discussão entre os novos adeptos vindos das escolas filosóficas e os dirigentes da nascente Igreja. (...)

O que se verifica é que a Igreja precisava lidar com multidões de fiéis incultos, que falavam mal o latim e não sabiam ler. Multidão também ruidosa e briguenta, que discutia e se batia até a morte por questões de fé. (...)

O caminho adotado pela Igreja foi uma crescente restrição de acesso do povo aos objetos e textos sagrados e, paralelamente, a imposição de verdades indiscutíveis, os dogmas, que começaram a surgir logo nos primeiros tempos da instituição, mas que foram se multiplicando no decorrer dos séculos. (MALANGA, 2005, p. 237-238)

O descontentamento com esse fechamento começou a surgir de várias maneiras, pois a igreja começou a utilizar dos dogmas para impor sua autoridade nos mais diversos setores da sociedade medieval, fato condutor de descontentamento não só entre o povo mais religioso, mas também entre os outros estratos sociais que precisavam obedecer calados às imposições dogmáticas da igreja que interferia no comércio, artes, e até mesmo na vida particular dos cidadãos.

Reações contra essa imposição interpretativa dogmática começaram a surgir na igreja

\footnotetext{
em: 19 ago 2012

${ }_{162}$ Para mais detalhes sobre essas obras vide Berkhof (2008, p. 23).

163 Essa visão da tradição como única fonte de autoridade interpretativa só será quebrada com o surgimento da Reforma Protestante, que comentaremos em seguida.
} 
cristã séculos antes da Reforma Protestante, principalmente com Nicolau de Lira $\left({ }^{\dagger} 1340\right)$, considerado o Jerônimo do século 14 (Farrar, 1886, p. 274). Lira era admirador dos estudiosos judeus de sua época, havendo estudado Rashi, enfatizou a importância do estudo das línguas originais e dos métodos de interpretação utilizado por estudiosos judeus. Conforme Farrar (1886, p. 274, nota 3) é de Rashi que provavelmente Lira tenha aprendido a antiga regra judaica, a qual ele expressa em forma latina como scriptura loquitur secundum modum nostrum loquendi (a Escritura fala de acordo com o nosso modo de falar) e da interpretação rabínica aprendeu o que chamava de sensu literaris (sentido literal, em hebraico פשט). Nicolau, embora não tenha abandonado completamente o espírito de sua época e ainda aceitando o sentido quádruplo, questionava, todavia, o sentido místico e "lamentou o fato de se permitir que 'o sentido místico sufocasse o literal', e exigia que o último só fosse usado na doutrina experimental" (BERKHOF, 2008, p. 23).

A obra de Nicolau de Lira foi fundamental como precursora de um questionamento ao fechamento católico da interpretação imposto pela autoridade imposta do ministério da igreja. Martinho Lutero (1483-1546) foi influenciado pela obra de Lira, sendo assim, indiretamente, Nicolau de Lira é precursor do ambiente questionador do dogma interpretativo da igreja católica na Reforma Protestante.

A Reforma Protestante, no século XVI ${ }^{164}$, é o período seguinte de maior importância na história da interpretação cristã, os princípios da Reforma são tradicionalmente resumidos nas chamadas cinco solae: sola fide (somente a fé); sola scriptura (somente a Escritura); solus Christus (somente Cristo); sola gratia (somente a graça); soli Deo gloria (glória somente a Deus). Estes cinco princípios são claros princípios contra o monopólio interpretativo da igreja católica, a sola fide significa que a salvação é recebida somente pela fé sem a necessidade das obras; o solus Christus é pelo fato do pensamento reformador de que somente Jesus é o intermediário entre Deus e os homens; o sola gratia se dá pelo entendimento que o homem não merece a salvação, mas é dada por Deus pelo seu favor imerecido, a graça; o soli Deo gloria tranfere toda dignidade a Deus e não ao homem ou qualquer autoridade humana instituída. Contudo, o princípio mais importante e orientador da interpretação bíblica na Reforma, é, evidentemente, a sola scriptura. Sobre esse princípio reformador diz Berkhof (2008, p. 24):

\footnotetext{
${ }^{164}$ A data oficial estabelecida como início da Reforma Protestante é 31 de outubro de 1517, data em que Lutero afixa à porta da igreja do castelo de Wittenberg, na Alemanha, as 95 teses contra a igreja católica.
} 
Os Reformadores criam na Bíblia como sendo a Palavra inspirada de Deus. Mas, por mais estrita que fosse sua concepção de inspiração, concebiam-na como orgânica ao invés de mecânica. Em certos particulares, revelaram até mesmo uma liberdade notável ao lidar com a Escritura. Ao mesmo tempo, consideravam a Bíblia como a autoridade suprema e como corte final de apelo em disputas teológicas. Em oposição à infalibilidade da Igreja, colocaram a infalibilidade da Palavra. Sua posição é perfeitamente evidenciada na declaração de que a Igreja não determina o que a Escritura ensina, mas a Escritura determina o que a Igreja deve ensinar. O caráter essencial da sua exegese era o resultado de dois princípios fundamentais: (1) Scriptura Scripturae interpres, isto é, a Escritura é a intérprete da Escritura; e (2) omnis intellectus ac expositio Scripturae sit analogia fidei, isto é, todo o entendimento e exposição da Escritura deve estar em conformidade com a analogia da fé. Para eles, a analogia fidei é igual à analogia Scripturae, isto é, o ensino uniforme da Escritura.

Esse ponto, sola Scriptura, será o ponto principal de discórdia entre os reformadores e a igreja católica e será o ponto de diferença entre o protestantismo e outras tradições religiosas cristãs, pois, além do catolicismo romano, as igrejas ortodoxas: grega, copta, russa, também têm a autoridade de seus patriarcas ou papa e na tradição da igreja, o elemento intermediador entre as Escrituras e o que essas significam, ou seja, o significado passa pelo crivo da tradição interpretativa estabelecida pela autoridade eclesiástica. A partir desse momento histórico, o cristianismo se dividirá exponencialmente entre a visão da tradição interpretativa e o direito do livre julgamento. O catolicismo romano, no Concílio de Trento $(1545-1563)^{165}$, confirmou a posição de que a Bíblia só pode ser interpretada pela tradição, ou seja, qualquer interpretação não autorizada das Escrituras é invalidada pela tradição da igreja.

Ao contrário da posição católica romana de atribuir autoridade inspirada para a Vulgata, os reformadores enfatizavam a necessidade de voltar aos originais hebraicos, aramaico e grego, assim, inicia-se no protestantismo, um período de estudos dessas línguas, ${ }^{166}$ o grande erudito biblista ${ }^{167}$ que deu suporte a Lutero nessa área foi Melanchthon.

Um exemplo da interpretação bíblica de Melanchthon, condenando o sentido quádruplo é dado por Bohlmann (1970, p. 53):

Haec duxi hoc in loco, de quatour sensibus dicenda esse, ut admonerem unam aliquam, ac simplicem, et certam sententiam in sigulis locis quaerendam esse, quae cum perpetuo contextu orationis, et cum circumstantiis negocii consentit. Nec ubique licet allegorias quaerere, nec temere aliud ex grammatica sensentia

\footnotetext{
165 O Concílio de Trento é considerado uma das muitas atitudes da igreja católica romana conhecidas por contrarreforma.

166 Esta volta à antiguidade clássica ou original da literatura, é, sem dúvida, elemento presente no espírito renascentista que foi influenciador da Reforma Protestante.

167 Nome dado a estudiosos bíblicos que se dedicam ao estudo das línguas originais da Bíblia, hebraico, aramaico e grego.
} 
ratiocinandum est, sed videndum, quid in unoquoque loco deceat, nec pugnantia figenda sunt cum articulis fidei. (Conduzi o debate a êste assunto, que se denomina dos quatro significados, para admoestar que, em cada passagem, é necessário procurar apenas um sentido simples e exato, que deve sempre concordar com o contexto do trecho, bem como com os assuntos precedentes e seguintes. Também não é lícito procurar alegorias em qualquer parte, nem é preciso temer que se deva deduzir outro sentido além do gramatical, mas importa cuidar que a interpretação de qualquer passagem não entre em conflito com algum artigo de fé $)^{168}$.

Melanchthon argumentará contra a visão católica da época que procurava se utilizar do sentido alegórico e do entendimento dos sentidos quádruplos para fundamentar as doutrinas católicas, e já que ninguém podia questionar a interpretação da igreja, que era a única autorizada a deduzir os sentidos das Escrituras, o texto bíblico era usado como transmissor da tradição interpretativa autoritativa, sem a possibilidade de questionamentos.

Embora Melanchthon seja o exegeta da Reforma, é Lutero a mente e o líder do movimento, tendo aprendido as línguas originais com Melanchthon, deu sua maior contribuição à liberdade de interpretação ao produzir a versão alemã da Bíblia em Hochdeutsch ${ }^{169}$ transformando-o em língua franca, podendo ser a sua tradução entendida em todo território europeu de língua alemã. O impacto da tradução da Bíblia por Lutero é esclarecido por Berman (2002, p. 51) com as seguintes palavras:

Difícil, mas aparentemente bem-sucedida: logo em seu aparecimento, a Bíblia luterana faz sensação, apesar de todas as críticas. As reedições se sucedem. Muito rapidamente, o povo ao qual ela era destinada decora passagens e a integra em seu patrimônio. Desde o início, torna-se a pedra angular da Reforma na Alemanha, como Goethe bem observou. Mas ela é ainda mais do que isso: transformando o Hochdeutsch em lengua franca, ela faz dele, durante séculos, o medium do alemão escrito. Na tradução luterana, estabelece-se uma primeira e decisiva auto-afirmação do alemão literário. Grande "reformador", Lutero é doravante considerado um escritor, como um criador de língua, e é assim que Herder e Klopstock o celebram.

Lutero não é, contudo, o grande exegeta da Reforma, mesmo tendo sido ferronho crítico se prende ainda ao sentido alegórico em muitas de suas interpretações. Tinha regras hermenêuticas melhores do que sua exegese (BERKHOF, 2008, p. 25). A grande contribuição para a interpretação bíblica de Lutero será sua defesa do direito de cada um de fazer sua própria análise ou interpretação do texto bíblico, conhecido como julgamento particular. Lutero dizia ainda que ao intérprete era necessário a fé e discernimento espiritual (Berkhof,

\footnotetext{
${ }^{168}$ Nestas últimas palavras "mas importa cuidar que a interpretação de qualquer passagem não entre em conflito com algum artigo de fé” nota-se que a Reforma já começa a formar a sua própria tradição interpretativa.

${ }^{169}$ Alemão padrão ou oficial.
} 
2008, p. 25) para que pudesse entender as Escrituras. Conduziu também à formação de uma tradição interpretativa no seio do cristianismo pós-reforma, já que, segundo Lutero, era necessário encontrar Cristo em todas as partes das Escrituras, ou seja, todo texto da Bíblia Hebraica, a partir dos princípios reformadores, precisavam dizer algo a respeito da pessoa e obra de Cristo.

Outro grande reformador precisa ser citado, João Calvino (1509-1564), foi maior exegeta do que Lutero, pois aplicava os princípios que defendia à sua prática exegética. Comentou todos os livros da Bíblia Cristã, exceto Apocalipse. Como todos os reformadores, condenava o método alegórico e entendia ser este uma maneira de obscurecer o verdadeiro sentido das Escrituras. Calvino resolvia a interpretação cristã Bíblia Hebraica com o uso do que chamava aspecto simbólico, ou seja, muitas passagens Bíblia Hebraica, para serem entendidas do ponto de vista cristão, teriam de ser vistas como símbolos de realidades superiores que haveriam de se cumprir em Cristo. Calvino discorda de Lutero de que Cristo tem de ser encontrado em toda a passagem do AT e em sua interpretação do livro dos Salmos reduziu os Salmos considerados messiânicos pela interpretação cristã tradicional. Para Calvino, "a primeira função de um intérprete é deixar o autor dizer o que ele diz, em vez de atribuir a ele o que ele deveria dizer". (BERKHOF, 2008, p. 25). Calvino, como os outros reformadores, também é enérgico em ir contra a necessidade do ministério da igreja católica ser o árbitro das Escrituras, e afirma isso com as seguintes palavras:

Porque se a Igreja cristã foi desde o princípio fundada sobre o que os profetas escreveram, e sobre o que os apóstolos pregaram, necessariamente se requer que a aprovação de tal doutrina preceda e seja antes que a Igreja, a qual foi fundada em tal doutrina; pois o fundamento é sempre anterior ao edifício. Assim, é um grau de desvario dizer que a Igreja tem autoridade para julgar a Escritura, de tal sorte que os homens venham a determinar o que se deva ter por Palavra de Deus ou não. (CALVINO, Institutas da Religião Cristã, Livro I, Capítulo VII, 3)

O pós-Reforma, entretanto, acabou incorrendo no mesmo princípio católico da autoridade da tradição sobre a interpretação das Escrituras, o que o protestantismo tanto criticou, acabou fazendo parte de sua práxis posterior. Esse período posterior à Reforma é denominado de Período do Confessionalismo ou Período Confessional. O princípio reformador Scriptura Scripturae Interpres era só teórico, na prática, as declarações ou artigos de fé, como já havia sido denominado por Melanchton, agora, era o princípio orientador das mais diversas linhas de confissão protestante. A época do confessionalismo pode ser denominada de época em que "a exegese se tornou a serva do dogmatismo e degenerou em 
mera pesquisa de textos-prova" (BERKHOF, 2008, p. 26).

Por volta do final do século XVII, surgirá no meio protestante um movimento reformador no próprio meio da igreja luterana, uma espécie de revolta contra o confessionalismo mecânico e destituído de espiritualidade, esse movimento é denominado de pietismo ou pietista. A origem do movimento está ligada ao nome de Philip Jacob Spener (1635-1705) e os maiores representantes da escola pietista são August Hermann Franche (1663-1727) e Johann Albrecht Bengel (1687-1752) ${ }^{170}$. A escola pietista, no entanto, acabou exagerando a ênfase no sentido místico, levando a exegese à interferência de uma visão espiritualizada das Escrituras, encontrando sentidos inexistentes no texto bíblico.

No século XVIII, o pietismo perpetuou-se na vida e obra de John Wesley (1703-1791), profundo estudioso das línguas originais e escritor de muitas obras que se perpetuaram como fonte de doutrina e entendimento bíblico das Igrejas Metodistas e posteriormente também a base das igrejas pentecostais. Paralelo ao pietismo estavam surgindo correntes racionalistas de interpretação bíblica por meio de filósofos, alguns de famílias tradicionalmente protestantes ou judaica, e outros influenciando no modo de se entender e interpretar as Escrituras.

O período seguinte é chamado de racionalismo, e é exposto por Kaiser Jr. e Silva (2002, p. 218) da seguinte forma:

Os primórdios do racionalismo filosófico estão em René Descartes (1596-1650), Thomas Hobbes (1588-1679), Baruch Spinoza (1632-77) e John Locke (16321704). O racionalismo teológico, entretanto, estava diretamente ligado a três fontes principais: Christian von Wolff (1679-1754), Hermann Samuel Reimarus (16941768) e Gotthold Ephraim Lessing (1729-81). Wolff procurou juntar a revelação bíblica à revelação natural a origem do Cristianismo. Lessing contribui para essas questões argumentando que as incertas verdades da História jamais poderiam ser uma prova para as verdades necessárias da razão. Assim, podemos dar crédito a esses homens por muito daquilo que mais tarde se transformou em Cristianismo liberal, incluindo a forma destrutiva de crítica à Bíblia nos séculos 19 e 20.

A interpretação da Bíblia agora não era mais serva da tradição da igreja católica ou das confissões protestantes, o racionalismo impunha ao estudioso analisar as Escrituras de acordo com as ciências humanas e os estudos filosóficos e filológicos da época. A religião protestante tornou-se uma religião ética e moral, não mais baseada em uma interpretação histórica de acontecimentos reais, mas de ensinos éticos e morais, não necessariamente fundamentados na Bíblia. Os grandes influenciadores desse pensamento foram Immanuel Kant (1724-1804), Friedrich Schleiermacher (1768-1834), Albrecht Ritschl (1822-89) e Adolf von Harnack

\footnotetext{
${ }^{170}$ De acordo com Kaiser Jr. e Silva (2002, p. 217) foi o primeiro estudioso a classificar os manuscritos do AT em famílias de baseado nas semelhanças dos mesmos.
} 
(1851-1930).

A época anterior às duas grandes guerras mundiais de 1914 e 1934 marcaram grandes mudanças na hermenêutica e exegese protestante. Os períodos anteriores à primeira guerra foram marcados por um otimismo teológico que esperava uma realidade utópica de harmonia e progresso, visão minada pelas duas grandes guerras que frustraram as expectativas e mudaram também a forma de entender e interpretar as Escrituras.

A obra de Karl Barth (1886-1968) e Rudolf Bultmann (1884-1976) serão as duas grandes vozes de mudança nos paradigmas da interpretação bíblica no meio protestante. A obra de Barth que causou grande impacto na interpretação da Bíblia foi seu comentário de Romanos, de acordo com Kaiser Jr. e Silva (2002, p. 222) “...o comentário não trouxe nada de novo para os estudos de Romanos. Sua visão ousada, entretanto, pôs em movimento uma transformação dramática na maneira dos teólogos encararem a interpretação bíblica."

As consequências da história da interpretação cristã será uma multiplicidade de vozes nas opções contemporâneas de interpretação bíblica, há os que se manterão dentro dos princípios da Reforma de Sola Scriptura, principalmente nos meios protestantes mais ortodoxos e pentencostais e as linhas que seguirão a chamada Teologia Liberal, mas alinhadas com a hermenêutica de Schleiermarcher, Barth e Bultmann, que estão mais concentradas nas Igrejas Históricas. ${ }^{171}$

Os impactos para a tradução da Bíblia também estarão presentes de acordo com os princípios de interpretação adotados pelas comissões de tradução, os que seguem linhas mais ortodoxas, de acordo com os princípios Reformadores mais radicais, preferirão traduções mais literais, por equivalência formal. Os que utilizam de traduções por equivalência dinâmica se dividem em alguns do ramo mais liberal da teologia protestante e os mais ortodoxos que não veem problema algum no uso de traduções mais dinâmicas.

\subsection{Princípios de Interpretação Rabínica}

De acordo com Malanga (2002, p. 195):

$\mathrm{Na}$ tradição judaica, poderíamos dividir o desenvolvimento da interpretação e da elaboração de comentário à Bíblia em três grandes períodos: o período simultâneo à redação do $\operatorname{Tanach}^{172}$; o período pós-bíblico, quando ainda existia o Segundo Templo; e um terceiro período, após a destruição do Segundo Templo, que vem até

\footnotetext{
${ }^{171}$ Curiosamente, a interpretação católica seguirá a escola Liberal Protestante de Schleiermarcher, Barth e Bultmann, autores protestantes, para seus comentários e exegese bíblicas.

172 Os negritos e itálicos são da autora.
} 
nossos dias. Essas largas faixas de tempo comportam, logicamente, subdivisões, mas essa separação tem como base dois princípios organizadores da religião judaica: o templo, quando este existia, e o Tanach, a partir do momento em que começou a ser escrito e conhecido pelo povo judeu. É preciso lembrar que o templo significava a presença do povo em sua própria terra, embora não obrigatoriamente em situação de liberdade. A inexistência de um templo, primeiro no exílio babilônico, e depois em um exílio de mais de 1.800 anos, levou a uma concentração da religião no Tanach e, em especial, na Torá.

Após a destruição do primeiro templo, os judeus tiveram que adaptar a sua religião ao contexto histórico em que viviam. Sem templo não era possível mais desempenhar as tarefas exigidas na Torah, visto que o culto da mesma estava centralizado no templo e no sacerdócio levítico. Com esse problema em vista, foi preciso uma reavaliação do judaísmo na Babilônia, era preciso manter a religião, ao contrário, o culto a YHWH (יהוח) seria suplantado pelos cultos pagãos da terra do cativeiro.

O profeta que procurou reavaliar a situação da nação, sem ir contra a verdadeira religião de YHWH foi Ezequiel, a quem geralmente se atribui o início da reunião para o culto judaico fora do templo (Ez 8.1; 14.1; 33.30), reunindo assim o povo em assembleias (קדילוֹ qhiloth). As tais assembleias, mais tarde, foi dado o nome de Sinagoga, do grego $\sigma u \nu \alpha \gamma \omega \gamma \hat{\eta}$ (synagôguê $)^{173}$, como são conhecidas até hoje, Bright nos explica seu surgimento (2003: 595596) :

(...) é inconcebível que os judeus da Diáspora pudessem ter permanecido judeus sem uma certa forma de adoração pública. Mesmo na palestina havia adeptos da comunidade judaica, muito afastados de Jerusalém para participar regularmente do seu culto, cujas necessidades teriam sido semelhantes. E também podemos supor que quando a lei ganhou posição canônica, os grupos começaram a reunir-se localmente para ouvir a sua exposição. Sinagogas organizadas surgiram gradualmente com adoração regular no Sábado, cuja parte principal era a leitura e a exposição da lei. Nos últimos séculos pré-cristãos, havia sinagogas em todas as cidades.

A sinagoga não é um termo da Bíblia Hebraica, contudo, foi um meio necessário para a continuação da religião de YHWH, sem ela, a nação de Israel estava fadada à ruína e perderia sua identidade. Com a corrupção do sacerdócio (Os 4.6-10 ${ }^{174}$ ), a queda do primeiro

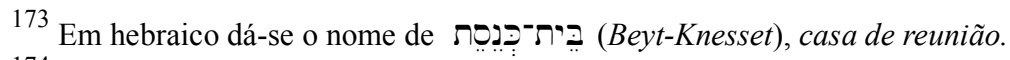

174 ainda que, geralmente, muitos pregadores se fixem na falta do conhecimento do povo, na exposição deste texto de Oseias, a sequência do versículo e o próprio contexto mostram a situação dos sacerdotes à época de

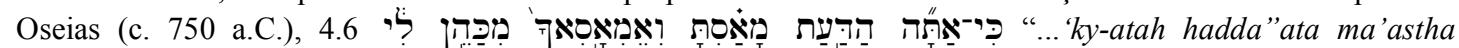
ve'emas 'kha mikahen ly..." "porque tu o conhecimento rejeitaste, eu rejeitarei a ti sacerdote diante de mim" (Tradução Literal) - a partícula ky indica o motivo pelo qual o povo está perecendo, é por ter o sacerdote rejeitado o conhecimento, e visto que era tarefa do sacerdote a transmissão e ensino da lei (Lv 10.11; Dt 17.8-
} 
templo e o surgimento da sinagoga, o ministério levítico começou a ser obscurecido pelo ministério profético, contudo, na volta do cativeiro babilônio foi restaurado por Esdras ( $\mathrm{Ne}$ 8.1-12) ${ }^{175}$. E eram os sacerdotes que ensinavam a Torah aos que voltaram da Babilônia. Esdras ainda, desempenhava a função de sofer (רפָ - escriba, escrivão, secretário KIRST et al. , 1987, verbete רִּר).

Foi com o ministério de Esdras que o ofício de escriba se tornou, pela primeira vez, identificado com os sacerdotes (veja Ed 7; Ne 8; 12.26, 36), embora tal atividade deva ter existido ininterruptamente antes disso ( $c f$., possivelmente, Sl 45.1 [2]). Com o exílio e o retorno, surgiu entre os sacerdotes uma categoria distinta de pessoas especialistas e sábias que eram não apenas guardiães e mestres da lei mas também seus intérpretes. Com o passar do tempo, o grupo passou a ser uma poderosa força sociopolítica e religiosa, conforme está documentado nas muitas referências a esses escribas na literatura intertestamentária e no NT. (DITAT $1540 \mathrm{c})$.

Esdras deu início a uma classe chamada ספרִ (soferim escribas), como ficaram conhecidos; vieram a ser os responsáveis pelo texto bíblico (ARCHER Jr., 1991, p. 62), assim, a transmissão e preservação da Bíblia Hebraica está sob o cuidado deles, o que fez com que o cargo tivesse uma grande importância tanto religiosa como social. Através deles foi padronizado um texto puro das Escrituras, de onde depois provieram todas as outras cópias (ARCHER Jr., 1991).

Os soferim, segundo a tradição judaica, começam com Esdras e se estendem até Antígono de Soco, do V ao III Século a.C., após eles segue-se um segundo grupo chamado zugoth (זרות = pares), desde José Ben Joezer até Hilel (ARCHER, Jr., 1991, p. 63). Um último grupo é chamado de Tana'im (תנאים, repetidores) ${ }^{176}$, desde a morte de Hilel até a morte de Judá Hanassi (após 200 d.C.).

Os Tanaim ${ }^{177}$ são os sábios da Mishná e os Amoraim ( אמראים, os que falam, entre 200-500 d.C.) são os sábios da Guemará (Talmude), recebem o título de Rabi ('ר ר = meu mestre) ou Rabban (ךר = nosso mestre). Deste grupo então, surgem os rabinos, que são os mestres da Torah, responsáveis por continuar o ensino da Lei ao povo de Israel. O Rabino

\footnotetext{
13), o povo sofria por causa do erro de seus líderes corrompidos.

${ }^{175} \mathrm{O}$ próprio Esdras era sacerdote $(8.2,9)$.

176 Também chamados de Tanaítas.

${ }^{177}$ O termo é usado para designar os sábios rabínicos cujas interpretações estão registradas na Mishná. Significa: repetidores.
} 
Meir, na Mishná, exalta a Torah com as seguintes palavras:

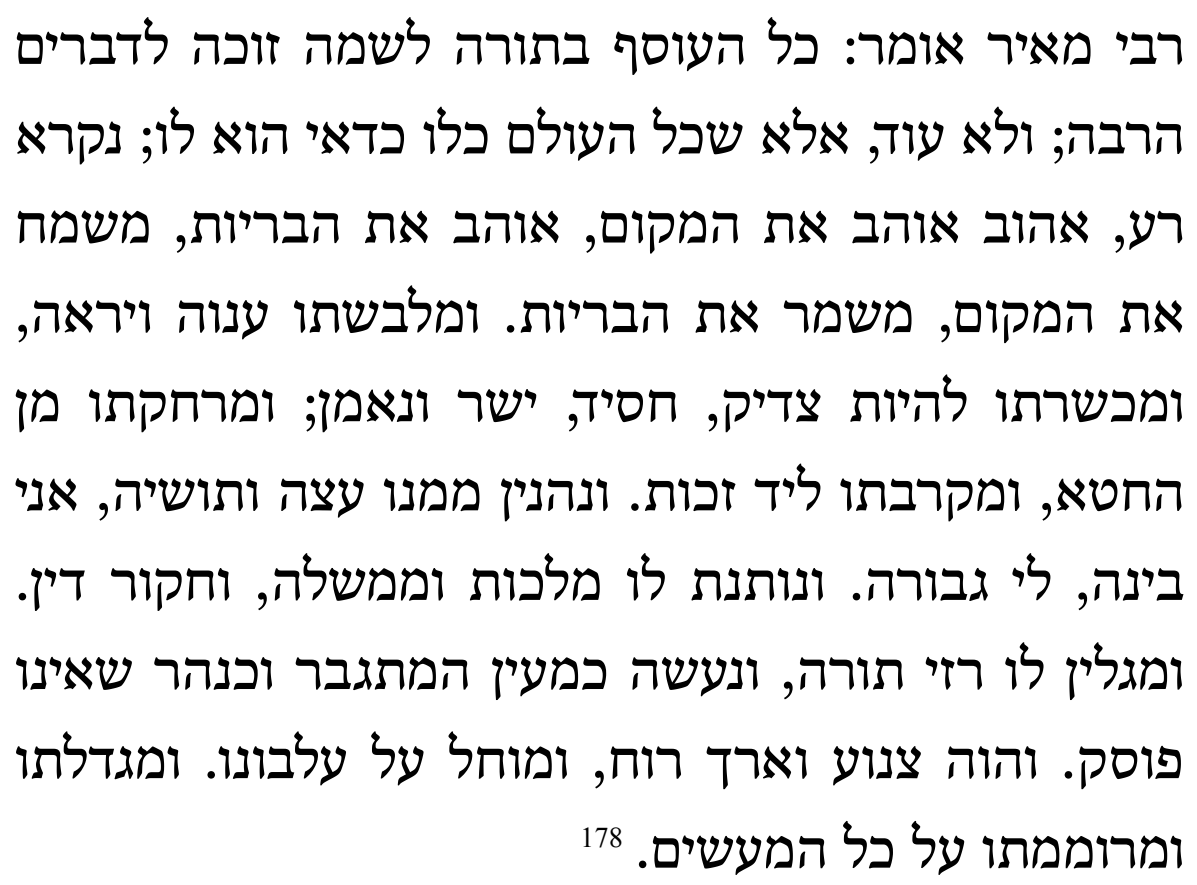

Rabi Meir diz: Todo o que se ocupa com a Torah pelo nome dela ${ }^{179}$, é merecedor de grandes coisas; e não só isso, mas que todo o mundo tem uma dívida para com ele. ${ }^{180}$ Ele é chamado amigo, amado, ama a Deus, ama as pessoas, se regozija em Deus, se regozija nas pessoas, e [o estudo] o veste de humildade e temor, o torna apto a ser justo, devoto, reto e fiel; afasta-o do pecado, e aproxima-o da pureza. ${ }^{181}$ As pessoas se beneficiam de seu conselho e sabedoria, entendimento e força, como diz: 'Meu é o conselho e sabedoria, eu sou o entendimento, minha é a força ${ }^{182}$, ela lhe dá reino e domínio, exame e julgamento. Desvenda para ele os mistérios da Torah, e [ele] é feito como uma nascente que não seca e como um rio em que não cessa. É modesto e paciente, perdoa a despeito das ofensas que lhe são feitas; [a Torah] o engrandece e o exalta sobre todas as obras.

No texto acima e em várias outras passagens da Mishná ${ }^{183}$, o estudo da Torah é exaltado, é visto como honrado aquele que se dedica a aprofundar-se nele. O evento da entrega da Torah a Moisés e ao povo de Israel no monte Sinai é visto como o evento mais

\footnotetext{
${ }^{178}$ Pirqey Avot 6.1.

179 para honra dela, ou por amor a ela.

180 a frase אלא שכל העולם כלו כדאי הוא לו 'ela'shekol ha"olam kulo kd'ay hu'lo" pode ser traduzida

por: "mas que todo o mundo, inteiramente, vale a pena por causa dele".

181 liydey zkhuth - literalmente "para mãos puras".

182 Pv 8.14.

${ }^{183}$ Pirqey Avot 1.6, 15; 4.8; 5.25, etc.).
} 
marcante da história do povo, segundo (GOLDBERG; RAYNER, 1989, p. 323):

...o Midrash acrescenta que 'quando Deus revelou a Torá, nenhum pássaro chilreou, nenhuma galinha bateu as suas asas, nenhum boi mugiu... o mar não se agitou, criatura alguma pronunciou qualquer som, o mundo estava quieto e calmo, e a Voz Divina falou' (Êxodo Rabá 29.9).

A palavra hebraica tem significados mais amplos do que simplesmente Lei, aparece em várias acepções no texto do Antigo Testamento, tais como: lei, instrução, ensino. Contudo, em seu significado mais elementar para o judeu hoje, a Torah é a Lei Escrita, dada a Moisés e ao povo de Israel no monte Sinai.

Os judeus exaltam a Torah acima de todos os outros livros sagrados, mesmo entre os outros livros canônicos da Tanakh. Há inclusive uma festa judaica chamada (Simchat Torah Alegria da Torah), que celebra a outorga da Torah.

Todos os Sábados na sinagoga, a pessoa que é chamada para fazer a leitura da Torah ora (SCHARFSTEIN, 1932, p. 102):

\section{ברכו את יי המברך}

a congregação responde:

\section{ברוך יי המברך לעלם ועד}

a pessoa que está dizendo a benção continua:

\section{ברוך יי המברך לעלם ועד}

\section{ברוך אתה יי אלהינו מלך העלם אשר בחר בנו מכל העמים, 184}

Assim, a Lei é essencial para o povo judeu, tanto em sua vida cotidiana como em sua vida

\footnotetext{
${ }^{184}$ Bareǩ u eth Adonay hamevorak. Baruk Adonay hamevorak l"olam va"ed. Baruk Adonay hamevorak l'olam va'ed. Baruk atha Adonay 'eloheynu melek há olam, 'asher bachar banu mikol há 'amim, natan lanu 'et torato. Baruk 'atah 'Adonay, noten hatorah. "Bendizei ao Senhor que é Bendito. Bendito é o Senhor que é Bendito eternamente. Bendito é o Senhor que é Bendito eternamente. Bendito és tu Senhor nosso Deus, Rei do Universo, que nos escolheu dentre todos os povos, e nos deu a tua Torah. Bendito és tu Senhor, [que] tem dado a Torah." (tradução nossa).
} 
religiosa. A Lei escrita é a base de todos os outros livros judeus, que a têm como fundamento de sua interpretação, tais como o Talmude e os comentários rabínicos da idade média. Para os judeus, a Torah é eterna e não pode ser mudada. Não está mais no céu, Deus a deu ao povo de Israel no Sinai. ${ }^{185}$

Os princípios hermenêuticos entre os rabinos se baseiam também em uma tradição herdada de gerações anteriores de grandes sábios de modo que não se pode desvincular a tradição herdada e são considerados grandes exegetas aqueles que interpretam textos bíblicos baseados em sábios que interpretaram os mesmos textos antes deles.

Nenhum intérprete pode interpretar nenhum texto bíblico de modo a contradizer o corpus de tradição já anteriormente herdada, se assim o fizer, tal intérprete será considerado pela comunidade judaica, no mínimo, como alguém que desconhece as leis judaicas.

Historicamente, os judeus tiveram que enfrentar vários problemas com respeito a interpretação bíblica; de acordo com a mudança das épocas as comunidades judaicas tinham dificuldades de viver a Torah e praticar seus mandamentos da mesma forma que foram dadas a Moisés. Assim, a hermenêutica rabínica formou-se a partir da necessidade de aplicar a Torah às novas realidades das comunidades judaicas.

São perceptíveis dois tipos de interpretação rabínica das Escrituras, já anteriormente citadas, as do tipo halakhah, que tinham por objetivo a interpretação de caráter legal, e as do tipo hagadah, que visavam ilustrar com histórias e até anedotas, ensinos da Torah, de acordo com a cosmovisão rabínica.

Berkhof (1988, p. 16-17) faz um comentário sobre um dos primeiros sábios rabinos a formular regras de interpretação bíblica:

Hilel foi um dos maiores intérpretes entre os judeus. Deixou-nos sete regras de interpretação, pelas quais ensinou, ao menos aparentemente, que a tradição oral devia ser deduzida dos dados fornecidos pela Lei Escrita. Estas regras, em forma sucinta, são as seguintes: a) Leve e pesado (isto é, a minore ad majus, e vice e versa); b) 'equivalência' ; c) dedução do especial para o geral; d) inferência de várias passagens; e) inferência do geral para o especial; f) analogia de outra passagem; g) inferência do contexto.

Não podemos dizer, entretanto, que houve concordância ao tipo de interpretação que deveria ser usado pelo judaísmo. Entre os caraítas, por exemplo, uma seita fundada por Anan Ben David, em cerca de 800 a.D. (BERKHOF, 1988, nota de rodapé, p. 18); não tinham regras de interpretação fixas, contudo, rejeitavam a lei oral e o tipo de interpretação rabínica.

${ }^{185}$ Baba Metzia 59b. 
Segundo os mesmos, só era necessário o estudo cuidadoso do texto das Escrituras, sem o auxílio da interpretação de ninguém.

Havia mesmo na época de Hillel, uma escola concorrente de interpretação, a chamada escola de Shammai,

Esta escola, acusava Hillel de modernismo pelo fato de admitir novas normas (halacôt) derivadas da Escritura. Shammai caracterizava-se por um talante conservador, patriótico, oposto aos influxos estrangeiros e contrário, por isso mesmo ao proselitismo entre os pagãos. Apesar das tendências rigoristas de sua escola, contudo, um em cada seis dos casos em que o Talmude recolhe as diferenças entre as duas escolas, a opinião de Shammai resulta ser a mais aberta (BARRERA, 1995, p. 567).

Sempre houve escolas de interpretação divergentes entre os judeus, tais como posteriormente a Hillel e Shammai, as escolas de R. Ismael e R. Aquiba e hoje também há diversos ramos do judaísmo que têm suas próprias visões quanto à interpretação das Escrituras e à tradição judaica, tais como o judaísmo ultraortodoxo, ortodoxo, conservador e liberal.

Conforme Barrera (1995, p. 571), quatro são os principais gêneros de interpretação hermenêutica entre os judeus: peshat (טשט) ${ }^{186}$, pesher (פשר) ${ }^{187}$, derash ${ }^{188}$ e alegoria, embora não pareça ser reconhecida essa distinção pelos rabinos, parece que havia pelo menos uma diferença no uso que faziam de tais gêneros de interpretação, de modo que possamos hoje usar uma classificação assim para fins de compreensão da hermenêutica rabínica.

O peshat (פט (ט) é o sentido mais óbvio do texto, ou seja, o literal, que qualquer pessoa pode entender ao ler um texto.

O gênero pesher (פשר) foi mais usado pelos membros da comunidade de Qumran (BARRERA, 1995, p. 572), é o sentido mais profético do texto e não o somente transmitido na época em que foi escrito.

Já o derash (דרש = investigar) ou Midrash (מדרשי), termos da mesma raiz hebraica, procura investigar sentidos escondidos no texto e não tão claros ao leitor normal.

A obra completa do Gênesis Rabbah constitui um exemplo de releitura midráxica

\footnotetext{
${ }_{187}^{186}$ peshath, sentido literal, literalidade, ou simples.

187 pesher, sentido, explicação, interpretação.

188 derash, interpretação homilética, exegese, sermão.
} 
do livro do Gênesis. Dá maior atenção à mensagem que pode ser extraída do livro para o presente e o futuro de Israel do que para a própria história narrada no livro. As figuras de Esaú, Isamel e Moab convertem-se em símbolos do Império Romano, o último dos quatro impérios cuja queda precederia a restauração de Israel (Pérsia, Grécia e Roma) (BARRERA, 1995, p. 574).

A alegoria não é bem aceita pelos rabinos modernos, embora tenha sido usada em grande escala na antiguidade da tradição judaica, obras alegóricas anteriores à época de R. Judá haNassi foram rechaçadas mais tarde no final do século II d.C., quando os rabinos da época se levantaram contrariamente à tendência de uma exegese alegórica (BARRERA, 1995, p. 575).

Stern acrescenta dois outros termos ao método de interpretação rabínico: a) Remez, exegese alegórica da Bíblia (BEREZIN, 1995, vocábulo iaר), "Características peculiares do texto são consideradas sugestões de uma verdade mais profunda do que a transmitida pelo sentido lato" (STERN, 1989, p. 96); b) Sod (סור = secreto):

Trabalha-se com os valores numéricos as (sic!) letras hebraicas; por exemplo, duas palavras que têm o mesmo número de letras serão boas candidatas para revelar um segredo através da 'bissociação de idéias'.

Esses métodos de interpretação formam o acróstico mnemônico PaRDeS (פרד): ${ }^{189}$

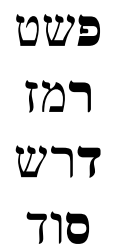

A Torah, como é entendida pelos judeus modernos, entretanto, não é somente a lei escrita por Moisés, mas também a sua interpretação, que segundo eles, também foi transmitida por Moisés. A esta interpretação, os judeus dão o nome de Torah Shebe"alpeh literalmente, A Lei que está nos lábios, ou seja, a Lei Oral.

Segundo a Mishnah (בישנה) ${ }^{190}$, a Lei oral foi dada a Moisés juntamente com a Lei

\footnotetext{
189 Quando entendemos o Novo Testamento como um escrito judaico, passamos a entender que as formas de citação e análise das Escrituras Veterotestamentárias são citadas nesse corpus de literatura, utilizando-se de princípios semelhantes ao pardes, tais métodos eram comuns na época neotestamentária, o que se evidencia pelo uso também em Qumran.

190 Coleção de Leis Orais compiladas por Rabi Judá Há-Nassi [200 d.C.], que forma a base do Talmude" 
Escrita, e que sucessivamente foi passada de Moisés para Josué, de Josué para os anciãos, dos anciãos para os profetas, dos profetas para os homens da grande assembleia knesseth hagdolah (כנסת הגדלי). ${ }^{191}$

A Lei Oral é composta pelo Midrash, Mishnah, Talmud e Tossefta' (ARCHER Jr., 1991, p. 64). Dentro da chamada Lei Oral existem dois tipos de literatura: a chamada hagadah, palavra que significa conto, lenda, que são espécie de ensinos em forma alegórica; e a halakhah, que é a parte propriamente legislativa da lei oral e tida como de maior importância pela tradição rabínica.

O Midrash, palavra que significa estudo, interpretação, pode ser um sermão homilético, como um ensino dado a discípulos. É basicamente do período tanaítico, e embora contenha grande parte de material de hagadah, é considerado propriamente como halachá, "testemunhas de uma época em que a Torá oral ainda era ensinada pelo método midrash" (GOLDBERG; RAYNER, 1989, p. 244). É uma exposição versículo por versículo da Torah e dos chamados Meguiloth (rolos), que são os livros de Ester, Cântico dos Cânticos, Ruth, Lamentações e Eclesiastes.

A Mishnah, palavra que significa estudo, doutrina, diferente do Midrash, está dividida em tópicos da Torah e não versículo por versículo. De acordo com (GOLDBERG; RAYNER, 1989, p. 248).

... é dividida em seis 'ordens'; cada ordem (em hebraico seder) é separada em uma quantidade de 'tratados' - o número original de tratados era sessenta, mas, por um processo de subdivisão, transformou-se em 63. cada tratado (massechet) é dividido em um certo número de capítulos; e cada capítulo (perek) é dividido em uma quantidade de parágrafos, cada um dos parágrafos sendo denominado uma mishná (no sentido original), ou halachá.

O Talmude, palavra que significa ensino ou aprendizado, é nada mais que um comentário da Mishnah, linha por linha, a esse comentário dá-se o nome de Guemara'. É basicamente uma tentativa de definir qual a opinião final sobre as opiniões colocadas na Mishnah. Há dois Talmudes: um chamado Yerushalmy ou Palestino e o outro chamado Bavly, ou Babilônio.

O Talmud Yerushalmy foi concluído por volta de 400 d.C., enquanto que o Talmud Bavly foi concluído por volta de 500 d.C. Nenhum dos dois comenta sobre todas as sessenta e três Mishnayot, o primeiro expondo trinta e nove e o segundo apenas trinta e seis. Ainda assim, o Talmud Bavly é muito maior do que o Yerushalmy. A edição inglesa de Soncino 
possui quinze mil páginas (GOLDBERG; RAYNER, 1989, p. 248).

A Tossefta' (ת), palavra que significa suplemento, é basicamente constituída das partes não contidas no Talmude. O Rabino Iehuda Hanassi, em sua composição da Mishnah, omitiu trechos que ele não julgava corretos, por conter posições divergentes. Essas outras opiniões estão na Tossefta', que é mais extensa que a Mishnah, inclui tradições da mesma, contudo, comenta sobre outros pontos divergentes da mesma. Entretanto, a Tossefta', nunca adquiriu a mesma autoridade que a Mishnah entre os judeus.

Após esta época temos o período conhecido como período dos Gueonim (גאנים), esse período é explicado por Kolatch da seguinte forma:

Durante os primeiros quinhentos anos após a edição final do Talmud - entre os anos 500 e 1000 - grandes eruditos, particularmente na Babilônia, continuaram o processo de interpretação da Bíblia. Eles também explicaram e comentaram a respeito do Talmud e obtiveram novas interpretações a partir de seus ensinamentos. Este período é conhecido como gaônico e seus eruditos, como gueonim (singular, gaón, significando 'sua eminência). Entre os mais conhecidos gueonim, estão Hai, Sherira e Amram, cada um dos quais chefe de uma academia de estudo numa cidade da Babilônia (KOLATCH, 1998, p. 5).

Devido a outras dificuldades que a tradição oral criara até então, os gueonim acrescentaram-lhe comentários para tentar resolver as questões que ficaram em aberto. Os gueonim recebiam perguntas de comunidades judaicas em todo o mundo a respeito de questões referentes ao Talmud, pois eram considerados autoridades talmúdicas em sua época, assim, cunhar-se-ia ao tipo de literatura pós-talmúdica do período gaônico o nome de Responsa, que significa Resposta, devido ao fato de serem respostas às perguntas dirigidas pelas comunidades. Essas respostas dos sábios gaônicos foram reunidas e mais tarde publicadas por seus discípulos. Este tipo de literatura é comum até hoje entre os judeus, que diante das novas dificuldades, decorrentes das novas situações presentes a cada época da humanidade, recorrem às autoridades rabínicas de seu tempo para obterem respostas a várias questões referentes à Torah e à ética. Geralmente, tais respostas, também são publicadas por alguma editora moderna que tenha a mesma linha do sábio rabínico questionado.

A Idade Média é o período de ouro dos grandes comentaristas talmúdicos que entrariam para história judaica como reshonim (ראשונים), os primeiros, sendo considerados os primeiros sábios. Dentre os grandes sábios desse período se destacam:

192 que significa: grandeza, eminência, altura, elevação, (BEREZIN, 1995, vocábulo â;: 
Rashi (Salomão ben Isaac, 1040-1105, norte da França), considerado um dos grandes exegetas judaicos; Abraão Ibn Ezra (1089-1164, Espanha); Rashbam (Samuel ben Meir, c. 1089 -c. 1174, norte da França), Moisés Ben Maimon (1135-1204) ${ }^{193}$, Radak (David Kimchi, 1160-1235, Provença), Ramban (Moisés ben Nachman, ou Nachmanides, 1195-1270, Espanha) ${ }^{194}$, Levi Bem Guershon (Guershonides, 1288-1344, Provença), Dom Isaac Abravanel (Espanha e Itália) e Obaida Sforno (c. 1470- c. 1550, Itália).

Semelhante ao que aconteceu depois da destruição do Segundo Templo no ano 70 d.C., os judeus tiveram que desenvolver suas leis para que pudessem sobreviver como povo e comunidade. Ainda, como viviam em um mundo cristão, foi nesse período que surgiram as principais discussões sobre a esperança messiânica, a ponto de haver calorosos debates entre judeus e cristãos.

Rabi Moses Ben Maimon, ou o famoso Ranbam, nas palavras de Hans Borger, foi uma das maiores autoridades rabínicas de todos os tempos (BORGER, 1999, vol. I, p. 387). Além de grande mestre talmúdico, Rambam foi médico e filósofo,

A intolerância religiosa, que veio vigorar na Espanha muçulmana, levara muitos judeus a adotar o islamismo pró-forma e grande número deles passou a viver sérios conflitos de consciência. Rabi Maimon, pai de Maimônides, reconhecida autoridade talmúdica ainda em Córdova, escreveu então um parecer, a carta de consolação (iguéret há-nehamah), no qual assegura a esses protomarranos que, se fizessem suas orações, ainda que de forma abreviada, e praticassem boas obras, eles continuariam a ser considerados judeus. Possivelmente, a família Maimon tenha vivido ela própria esse drama dos judeus secretos. Tanto assim que o próprio Rambam voltou ao doloroso problema. Em sua carta aos conversos forçados (iguéret há-shemad), Maimônides censura vigorosamente a reprovação dos 'forçados', que vinha sendo expressa por alguns rabinos extremistas e não lhes poupa a reprimenda de 'sábios presunçosos, que nunca experimentaram o que tantas comunidades tiveram que suportar em matéria de perseguição'. Na opinião de Maimônides, uma transgressão fingida da Lei não pode ser igualada a uma rejeição espontânea dela; contudo, o judeu deve fazer todo o possível para deixar o país no qual é obrigado a transgredir a lei divina (BORGER, 1999, vol. I, p. 387).

Maimônides era amante da simplificação e do equilíbrio para que o judaísmo fosse mantido em tempos de perseguição tão difíceis como o seu; ele pode ser chamado de sintentizador do judaísmo e da codificação da Lei. Em sua obra mais importante, o

\footnotetext{
${ }^{193}$ Maimônides merece uma discussão a parte, que será feita na seqüência, devido a sua grande erudição, audácia e controvérsia que provocou e ainda provoca.

${ }^{194}$ Nachmânides estará presente no histórico debate entre judeus e cristãos promovido pelo rei de Jaime I de Aragão (Jaime, o Conquistador, 1208-1276), que se deu em Barcelona em 1263, onde foram discutidas as posições judaicas e cristãs a respeito da esperança messiânica, Nachmanides escreverá sua versão do debate que é conhecida como vikuach (ויכוח), que significa debate.
} 
Comentário à Mishnah, Rambam sintetiza a Mishnah, extraindo dela somente o que achava útil e, nos pontos divergentes, ele decide pelo que acha mais correto deixando de lado as outras opiniões divergentes.

Maimônides levou dez anos para terminar esta obra, a qual escreveu em árabe com caracteres hebraicos. Foi duramente criticado pelos rabinos de sua época, pois estava se colocando como palavra final em decisões legais e como autoridade última em questões talmúdicas.

Em seu comentário ao último tratado da Mishnah, Maimônides sintetiza a fé judaica nos conhecidos Treze Artigos da Fé que afirma: 1) a existência de Deus; 2) Sua unidade; 3) Sua incorporeidade; 4) Sua eternidade; 5) a adoração só a Deus, sem intermediários; 6) a Profecia; 7) o destaque de Moisés entre os profetas; 8) a Torah, dada por Deus; 9) a imutabilidade da Torah; 10) a onisciência de Deus; 11) recompensa e castigo; 12) a vinda do Messias; 13) Ressurreição (BORGER, 1999, vol. I, p. 389).

Maimônides, escreve ainda, uma outra obra de grande importância, a chamada Mishneh Torah, na qual afirma na introdução que o trabalho dos gueonim era muito difícil de entender e que ele havia se dedicado o bastante para que o estudante, ao ler a sua obra, não necessitasse de tanto trabalho para determinar o que era ou não proibido na lei judaica. Chegou a afirmar que bastava estudar a Torah de Moisés, a primeira e depois a sua, a segunda (BORGER, 1999, vol. I, p. 390). ${ }^{195}$

O século XIII testemunhará o desenvolvimento de um tipo de interpretação mística da Bíblia Hebraica conhecida como קבלה (Qabalah). A palavra hebraica Qabalah, significa tradição e também uma quantidade enorme de interpretações místicas da Tanakh. Contudo, Scholem nos explica melhor a abrangência do termo:

Cabala, cumpre lembrar, não é o nome de um certo dogma ou sistema, mas antes o termo geral atribuído a todo um movimento religioso em si. Este movimento, com cujas etapas e tendências principais precisaremos familiarizar-nos, tem se desenvolvido desde os tempos talmúdicos até os dias de hoje; seu desenvolvimento foi ininterrupto, embora de forma alguma uniforme, e muitas vezes dramático. Vai do Rabi Akiva, que, segundo o Talmud, deixou o 'Paraíso' da especulação mística são e salvo, tal como nele penetrara - o que não se pode, na verdade, dizer de todos os cabalistas - ao falecido Rabi Abraham Isaak Kook, o líder religioso da comunidade judaica da Palestina e um esplêndido espécime de místico judeu

195 A importância de Maimônides para nosso trabalho se dá devido a seção de sua Mishneh Torá, chamada Hilchot Melachim (As Leis sobre os Reis), dedicados à questão do Rei Messiânico. 
(SCHOLEM, 1972, p. 19).

Dentre os livros mais influentes da qabalah estão o Sefer haYetsirah (Livro da Criação) e o Sefer haZohar (Livro do brilho, resplendor). O Zohar, durante vários séculos, alcançou o nível de importância para os judeus, como a Bíblia e o Talmud (SCHOLEM, 1972, p. 157). Segundo Scholem o livro é obra de um único autor incerto, mas talvez Moisés de Leon (SCHOLEM, 1972, nota de rodapé, p. 160-166). O tipo de interpretação é grandemente mística utilizando-se principalmente da facilidade da língua hebraica de formar palavras e de valor numérico das letras.

Todo esse corpus de tradição interpretativa norteará o judaísmo rabínico de modo a ser o orientador da exegese bíblica, sem esse corpus nenhuma interpretação será válida, e também, qualquer tradução que discorde dessa tradição interpretativa será rechaçada pelo judaísmo rabínico. A tradição, assim, será a validadora das traduções e, em alguns casos, a criadora de tradições que se adequem ao establishment interpretativo. 


\section{História das principais traduções (versões) antigas da BH}

As antigas traduções ou versões da Bíblia Hebraica são reflexo de uma vasta história de transmissão do texto, de princípios de interpretação e da força da tradição interpretativa, que produziu tanto o texto massorético, os textos de Qumran como as mais diversas versões tais como a LXX, Vulgata, Peshitta, Targuns e tantos outros textos, que tornam presente em seus princípios de tradução e de elaboração interpretativa o que pensavam teologicamente os diversos grupos que produziram esses textos.

Tov (2001, p. 122) discute a problemática das antigas versões da Bíblia Hebraica com as seguintes palavras:

A importância das antigas traduções para o criticismo textual da Bíblia era mais evidente antes de 1947 do que em tempos recentes, desde antes das descobertas dos rolos de Qumran, manuscritos de antigas traduções eram as mais antigas fontes do nosso conhecimento do texto bíblico. Na ausência de material antigo em hebraico, estudiosos davam muita importância a antigas traduções, desde que elas eram atestações mais antigas (no caso da $\mathfrak{\sigma}$ : fragmentos de papiros do segundo e primeiro século A.E.C e manuscritos do quarto século C.E.) precediam os manuscritos medievais do $\mathfrak{2} \mathfrak{i}$ em muitos séculos

As descobertas de Qumran assim, aparentemente diminuíram o valor das antigas traduções, desde que a confiança no texto hebraico é preferível ao uso de antigas traduções das quais a fonte hebraica é desconhecida. Os rolos de Qumran, são, entretanto, muito fragmentários, e mesmo se eles fossem completos, algumas antigas traduções, especialmente a $\boldsymbol{\sigma}^{196}$, permaneceria altamente significativa, desde que reflete um importante tradição textual que difere de ambos, do $\mathfrak{2}^{197}$ e os textos de Qumran. Várias leituras importantes também são refletidas em outras traduções.

As versões antigas, contudo, permanecem mais como testemunhas do desenvolvimento de diversas tradições interpretativas do que como testemunhas de um Vorlage $^{198}$ diferente do Texto Massorético e, por isso, traçaremos abaixo um breve histórico dessas principais versões da Bíblia Hebraica, como tais versões foram produzidas como fruto de tradições interpretativas, e, também, como geradoras, direta ou indiretamente, do establishment interpretativo das tradições judaico-cristãs.

\footnotetext{
${ }^{196}$ Caractere gótico usado na crítica textual para representar a Septuaginta.

${ }^{197}$ Caractere gótico usado na crítica textual para representar o Texto Massorético.

198 Dá-se o nome de Vorlage 'padrão, modelo’ ao texto base utilizado para se fazer a tradução
} 


\subsection{LXX}

A história da versão grega abrange um período de transmissão que vai desde o século III a.C. até o século IV d.C. Dentre todas as versões da Bíblia Hebraica, é, de longe, a mais controversa e a mais utilizada no debate judaico-cristão, principalmente na questão messiânica. A LXX foi produzida por judeus helenistas no século III a.C., amplamente utilizada no ambiente judaico até o século II d.C., quando foi rejeitada pelo judaísmo farisaico e substituída pelas versões de Áquila, Símaco e Teodocião. Foi utilizada nos círculos cristãos como versão preferida e oficial até o século IV d.C., e também substituída nessa época pela versão latina de Jerônimo conhecida como Vulgata, quando o grego começou a perder o uso no Império e ser substituído pelo latim como língua franca.

A principal fonte de informação sobre a produção da versão grega dos Setenta está na Carta de Aristéias, posteriormente reproduzida por Flávio Josefo (37 a.C. - 100 a.D.), bem como nos textos de Filo de Alexandria (25 a.C. -40 a.D.) e nos fragmentos de texto de Aristóbolo, preservados em várias fontes. Nenhuma dessas fontes, contudo, pode ser utilizada como evidência definitiva sobre a produção da versão, sendo sua história muito mais complexa do que comumente é divulgado na literatura menos acadêmica sobre o assunto.

A Carta de Aristéias, embora contenha algumas informações que podem ser consideradas verídicas ${ }^{199}$, em sua maior parte se trata de propaganda em defesa da superioridade da lei judaica e da versão grega como sendo produção miraculosa. Filo de Alexandria, os pais da igreja e os fragmentos de Aristóbulo seguem também a mesma linha, ou seja, equiparar a tradução grega ao texto original hebraico como obra de inspiração divina. De acordo com Würthwein (1995, p. 51):

Nos parece a primeira vista estarmos particularmente bem informados sobre as origens da $\mathfrak{G}$, desde que nós temos na Carta de Aristéias um relato que pretende ter sido compilado por alguém que era ele mesmo um participante na preparação da versão. O relato conta de como um dia, Demetrius Falero, que é erroneamente identificado como diretor da famosa biblioteca de Alexandria, relatou ao seu mestre real, Ptolomeu II Filadelfos (285-247 a.C.) que a Lei Judaica (a carta de Aristeias esta relacionada somente com o Pentateuco!) foi digna de um lugar na biblioteca real, mas que esta deveria primeiramente ser traduzida para o grego.

(...)

Este é o relato da Carta de Aristeias, o qual foi aceito e que recebeu desenvolvimento posterior por outros, ambos, judeus e cristãos. Josefo (37/38 - ca.

\footnotetext{
${ }^{199}$ Segundo Barrera (1998, p. 303) "a carta é atualmente uma ficção histórica, muito inexata em alguns detalhes, mas em essência baseada na verdade”.
} 
100) preserva este relato em sua fiel forma literal. Filo (ca. 25 a.C. - a.D. 40) faz da tradução um ato de divina inspiração, e aos tradutores, profetas: que, embora tenham trabalhado separadamente, produziram um texto que era literalmente idêntico em sua totalidade. Os pais da igreja, seguindo Filo, estenderam o relato da Lei, como está na Carta de Aristeas, a todo o Antigo Testamento.

Würthwein (1995, p. 52) ainda relata que muitas das informações da carta são inacreditáveis em muitos aspectos: o autor não é um pagão da corte como professa, mas um judeu que pretende louvar a sabedoria da Lei do seu povo e coloca esse louvor nos lábios de um rei pagão para tornar o relato mais crível para o mundo helênico. O escritor também não vive nos dias de Ptolomeu Filadelfo, mas mais de um século depois. E, ainda segundo Würthwein (1995, p. 52), a Lei judaica não foi traduzida com o propósito de satisfazer a curiosidade de um patrono real das artes, mas pelo fato dos judeus egípcios não dominarem mais a língua hebraica e, portanto, necessitarem de uma tradução da Bíblia Hebraica para o grego. Também para Würthwein (1995, p. 52): “os tradutores não eram judeus palestinos, mas membros da diáspora alexandrina da qual o grego era a língua da vida diária".

Em síntese, a LXX não pode ser tratada como uma obra oficial feita por um grupo de judeus em um determinado período da história, mas uma coletânea de vários textos traduzidos em diferentes épocas, em diferentes lugares e por tradutores com os mais diversos conhecimentos do grego e do hebraico, e que, finalmente, estabeleceu-se como uma obra única somente no século III d.C. através do trabalho de compilação de Orígenes. A principal análise feita para se chegar a tal conclusão é a evidência interna do texto grego que temos disponível, esse texto revela diferentes tipos e estilos de grego e diferentes autores, no caso de determinados livros, até mesmo a mão de dois ou três autores diferentes. Sobre tal análise nos informa mais uma vez Würthwein (1995, p. 53):

A tradução de livros individuais não são de forma nenhuma uniforme, e as diferenças que ocorrem até mesmo em um único livro tem levado Henry St. John Thackeray, assim como Johannes Herrman e Friedrich Baumgärtel, a suspeitar que Isaías, Jeremias e os Profetas Menores foram divididos entre dois tradutores, enquanto Ezequiel foi obra de três. É provável que no caso do Pentateuco, cada livro tenha sido obra de um único tradutor (ou grupo de tradutores), mas não há dois livros que tenham sido traduzidos pelo mesmo tradutor. Muitos livros são mais literais, enquanto outros tais como Jó e Daniel são mais livres.

A divisão dos tipos de grego feita por Thackeray (1909, p. 13) é feita de acordo com uma análise do grego apresentado em cada livro da LXX, mostrando a diferença de qualidade 
e estilo da versão, e evidenciando a 'mão' de diferentes tradutores em épocas e locais diferentes.

Uma outra análise do texto grego da LXX é feita através de técnicas de tradução juntamente com auxílios lexicógrafos para estabelecer a origem geográfica de cada livro da LXX (Barrera, 1998, p. 303):

Os livros da Torá, Juízes, 1-4 Reis, 1-2 Paralipomena ${ }^{200}$, 3 Macabeus, Provérbios, Jó, os 12 Profetas, Isaías (Van der Kooij), Jeremias, Baruque, Carta de Jeremias, Ezequiel, etc., foram traduzidos em Alexandria.

Os livros de Rute, Ester, Qohelet ${ }^{201}$, Cantares, Lamentações, Judite, I Macabeus, etc., foram traduzidos na Palestina. O tradutor de Sabedoria foi evidentemente um Judeu Alexandrino de origem Palestina, como foi também o tradutor de Ben Siraque.

Essas duas análises do tipo de grego que temos na LXX, tanto a análise dos tipos encontrados na versão como a hipótese da origem geográfica de seus tradutores, são evidência de que a versão se trata de uma coletânea de textos e que, embora contribua para a crítica textual como uma leitura divergente do texto massorético, sua maior importância está no campo da exegese mais do que da crítica, pois revela uma interpretação pré-cristã e prérabínica dos textos da Bíblia Hebraica, contribuindo para que possamos entender o desenvolvimento das tradições interpretativas nessas correntes religiosas.

As leituras interpretativas da LXX foram utilizadas como fundamentação para os discípulos de Jesus e pela posterior igreja cristã em formação, principalmente em textos considerados messiânicos dentro da tradição judaica anterior ao desenvolvimento da corrente rabínica mishnaica e talmúdica.

Rahlfs nos relata sobre a corrente rabínica, principalmente liderada por Aquiba e seus discípulos (in Septuaginta, 2011, p. LXXXII):

Nos três primeiros decênios do segundo século d.C., por influência do rabino Aquiba, impôs-se entre os eruditos judeus uma orientação no sentido de valorizar cada letra do texto sagrado. Isto fez com que dos elementos mais insignificantes do texto se tirassem conclusões das mais abrangentes e, em muitos casos, exêntricas. (...) Aquiba entendeu que, a partícula indicativa do objeto direto que aparece diante

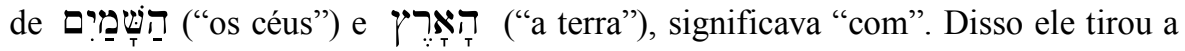
conclusão de que, "juntamente com o céu e a terra", Deus havia criado ainda outras coisas, a saber, com o céu ele criou o sol, a lua e as constelações; e, com a terra, árvores, plantas e o jardim do Éden. É óbvio que uma tradução mais livre, como a

\footnotetext{
${ }^{200}$ Nome grego para os livros de Crônicas.

${ }^{201}$ Nome herbraico do livro de Eclesiastes (קהלת).
} 
que em muitos momentos aparece na Septuaginta, não mais satisfaria uma erudição bíblica que dependia tanto assim de cada letra do texto.

Em razão disso, o judaísmo daquele tempo fez para si uma tradução grega do Antigo Testamento totalmente nova. Áquila, um prosélito grego e discípulo de Aquiba, traduziu ao grego todos os detalhes do texto sagrado da forma mais exata possível, não tendo nenhum receio de cometer os mais graves atentados contra o espírito da língua grega.

Em constante debate com a tradição interpretativa cristã, que se utilizava da LXX como base de suas doutrinas, essa versão foi rejeitada pelo rabinato, e, a partir do século II d.C., teremos, então, outras versões concorrentes da LXX tais como as de Áquila, de Símaco e de Teodocião, produzidas pelo judaísmo formativo do segundo século e que serão usadas no ambiente judaico como versão apologética contra o uso cristão da mesma.

Com vistas a resolver esse debate, ou pelo menos dar subsídios a cristãos eruditos, Orígenes produziu um trabalho de grande valor para crítica textual para sua época e para todas as épocas. De acordo com Kahle (in RAHLFS, 2011, p. LXXXVI):

A Hexapla de Orígenes se destinava exclusivamente ao uso dos eruditos. Em especial, segundo ele mesmo se expressou numa carta a Júlio Africano, devia servir de arma para o polemista cristão em sua luta contra os judeus. Devia colocar esse polemista numa posição em que poderia derrotar os judeus com as armas deles e passar a ter o respeito daqueles que sempre recorriam ao texto hebraico do AT e ridicularizavam o adversário, que operava com base na LXX. No contexto da igreja, Orígenes queria que o uso já tradicional da LXX fosse mantido. Para tanto, invocou o ditado [sic!]: "Não deves mudar as fronteiras eternas, que teus antepassados demarcaram". ${ }^{202}$ Também é verdade que, já pelo seu tamanho colossal, a Héxapla (e a Tétrapla, que resultou da eliminação das duas colunas hebraicas) não pôde ser mais amplamente difundida. Assim, no que concerne à configuração do texto bíblico, ela ficou quase sem nenhum efeito prático.

As seis colunas eram divididas da seguinte forma:

\begin{tabular}{|c|c|c|c|c|c|}
\hline Texto & Transliteração do & Texto Grego de & Texto de & Recensão da & Texto de \\
Hebraico Pré- & Texto Hebraico em & Áquila & Símaco & Septuaginta & Teodocião \\
Massorético & Caracteres Gregos & & & & \\
\hline
\end{tabular}


A LXX tornou-se a versão padrão utilizada pela Igreja Cristã até o surgimento da Vulgata de Jerônimo, que se tornará a próxima versão canonizada na Igreja, e que perdurará até a Reforma Protestante como versão oficial do cristianismo.

\section{2 Vulgata}

O processo de produção da versão conhecida hoje como Vulgata ${ }^{203}$ não foi simples e nem rápido, começou em 390 d.C. e durou até 405 d.C.. E dificilmente poderia ter sido executado por outro estudioso cristão que não Sofronius Eusebius Hieronymus (c. 347-420 d.C.), mais conhecido por são Jerônimo ou Jerônimo de Estridônia, também patrono dos tradutores.

De acordo com Ackroyd e Evans (1993, p. 510) "Jerônimo foi, depois de Orígenes, o maior estudioso bíblico da Igreja primitiva" e, após Jerônimo, somente a Reforma Protestante testemunhará um estudo semelhante das línguas originais da Bíblia (hebraico, aramaico e grego). De pai e mãe cristãos, recebeu educação eclesiástica desde o princípio e também foi educado nos clássicos greco-latinos desde muito jovem. A obra de Jerônimo foi tão popular que se tornou, como já dito, a próxima versão canonizada da Igreja Cristã, sendo até mesmo proibido o uso de outra versão e traduções para o vernáculo. O Concílio de Trento (1546) declarou a versão "exclusiva, fiel e, sobretudo, oficial. Além disso, foi considerada única, suficiente e fonte de fé e moral para os cristãos de tradição católica." (FRANCISCO, 2008, p. 517)

Inicialmente, porém, não era o objetivo de Jerônimo fazer uma nova tradução da Bíblia. Quando, a princípio, convocado pelo Papa Dâmaso I em 382 d.C., não foi para produzir uma nova versão, mas sim para fazer uma revisão dos evangelhos da Vetus Latina. Posteriormente, Jerônimo também fez uma revisão do livro dos Salmos e do livro de Jó. Após a morte do Papa Dâmaso I em 384 d.C., Jerônimo resolveu produzir uma nova versão da Bíblia toda com base nos textos hebraicos e aramaicos que tinha acesso na época. Para isso, Jerônimo se concentrou em estudar hebraico e siríaco, o que fez com muita dificuldade, mas como tinha aptidão para línguas e era persistente, teve grande êxito em seus estudos. Chegou a ser fluente em siríaco e passou a fazer referências diversas a essa língua em seus trabalhos

203 O termo Vulgata, que significa comum só foi atribuído à versão a partir do século XIII (ver FRANCISCO, 2008, p. 522). 
(ACKROYD; EVANS 1993, p. 517).

A abordagem de Jerônimo para fazer uma tradução com base nos textos originais hebraico e aramaico ${ }^{204}$ e não na LXX causou estranheza e até protestos por parte dos seus contemporâneos, de acordo com Francisco (2008, p. 521):

A nova versão latina não foi aceita imediatamente e, logo em seguida à sua publicação, sofreu forte oposição e críticas por parte de vários eclesiásticos, inclusive Agostinho de Hipona considerou-a desnecessária e Rufino de Auquiléia declarou-a herética. Agostinho chegou a questionar a escolha de Jerônimo pelo texto hebraico ao invés da LXX. Havia a resistência daqueles que se apegavam à Vetus Latina e, principalmente, à LXX que era considerada com respeito e possuía grande autoridade.

Outro fator causou debate sobre a tradução de Jerônimo, ele defendeu o cânon hebraico em sua tradução e não o cânon da LXX, impondo, assim, uma Bíblia Hebraica de influência rabínica para o mundo cristão de sua época. Embora não tenha colocado os deuterocanônicos em sua versão, Jerônimo fez uma revisão, com base no aramaico, de alguns desses livros da Vetus Latina, tais como Judite e Tobias, outros livros deuterocanônicos deixou sem revisão (FRANCISCO, 2008, p. 521).

Jerônimo defende-se das acusações e explica as razões de usar o texto hebraico e não a LXX com as seguintes palavras:

Se alguém preferir a edição dos Setenta (a Septuaginta), ela está aí disponível, pois foi corrigida por mim. Porque, ao fazer a nova, não é nossa intenção destruir a antiga. E, se os amigos lerem com cuidado, vão descobrir que nossa versão é mais inteligível, porque não se tornou amarga por ter sido derramada três vezes em diferentes jarros, mas foi retirada direto da prensa e guardada em um jarro limpo, o que fez com que preservasse o seu próprio sabor. (apud MILLER; HUBER, 2006, p. 108)

Quanto à qualidade e princípios de tradução da versão de Jerônimo, não há uma unanimidade em seu trabalho, embora preferisse, para as Escrituras, a regra do verbo verbum, ou seja, palavra por palavra, não adotou esse princípio em todos os livros da Bíblia Hebraica que traduziu. Nos livros proféticos e históricos adotou uma tradução mais literal, mas nos poéticos utilizou de uma tradução mais livre.

O que chamamos hoje de Vulgata não corresponde exatamente à obra realizada por Jerônimo. Depois da objeção inicial a versão de Jerônimo alcançou ampla aceitação da igreja 
cristã e passou a ser obra oficial, contudo, acrescentou-se à versão os livros que não foram traduzidos por Jerônimo (BARRERA, 1998, p. 355).

Por fim, é preciso lembrar que a Vulgata moldou o pensamento e a terminologia Ocidental dos anos subsequentes à sua produção, nas artes, pintura, literatura e pensamento teológico continua a influenciar e manter uma tradição interpretativa cristã do texto da Bíblia Hebraica.

\subsection{Targum}

Tão antigo como a Bíblia Hebraica, existe o costume de se traduzir o texto do hebraico para o aramaico e explicá-lo, a fim de que os que não entendiam mais o hebraico pudessem acompanhar a leitura, essa tradição é encontrada na Bíblia Hebraica quando do retorno do cativeiro babilônico. Esdras, o escriba, juntamente com os levitas leem a Torah ao povo e explicam o sentido, conforme está registrado em $\mathrm{Ne} 8.8$ :

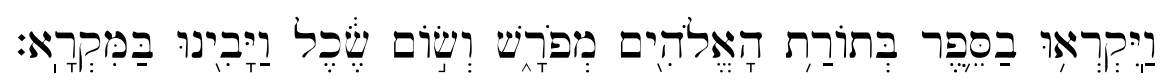

E leram no livro da lei de Deus sendo explicado e dado o sentido e o entendimento na leitura.(tradução nossa)

Essa tradição passou posteriormente a ser incorporada nas Bíblias feitas para a comunidade judaica, que geralmente incluem tanto o texto hebraico e sua tradução quanto o texto do targum sem tradução. A raiz תרגם (trgm) aparece uma única vez na Bíblia Hebraica em Ed 4.7 e significa tanto traduzir como interpretar.

O texto mais antigo de um targum conhecido, até hoje, é o que foi encontrado na caverna 11, entre os manuscritos do deserto da Judeia, catalogado pela sigla 11QtgJó, datado do século II a.C. Outros targumim (plural de targum) foram encontrados em outras cavernas de Qumran tais como o targum de Levítico 4QtgLv e um outro targum de Jó, encontrado na caverna 4 e catalogado como 4QtgJó. ${ }^{205}$

A possível origem dos targumim no é explicada por Francisco (2008, p. 475):

No serviço religioso da sinagoga, quando era lido o texto hebraico do Pentateuco, fazia-se a tradução aramaica de maneira simultânea ou após a leitura de cada 


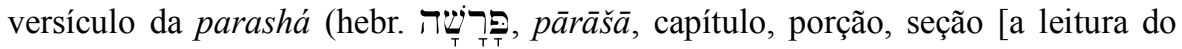
Pentateuco]) e ao mesmo tempo ou logo após a leitura de cada dois ou três

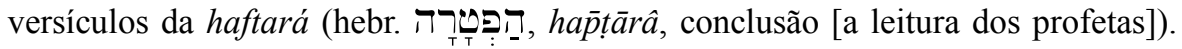
Esse trabalho era feito por um intérprete ou tradutor profissional

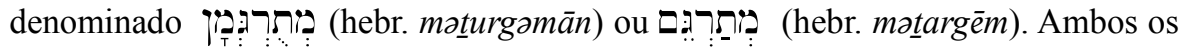
vocábulos significam "intérprete", o qual fazia sua tradução oralmente e sem o auxílio de um texto escrito previamente.

Essas traduções orais também incluíam interpretações, que depois foram incorporadas aos textos escritos, assim, os targumim são textos que revelam não só traduções, mas também tradições interpretativas dos textos da Bíblia Hebraica anteriores e posteriores ao judaísmo formativo e ao cristianismo primitivo.

Dentre os targumim mais importantes estão:

Targum de Ônquelos, do século II d.C. ao século IV d.C., contém elementos tanto do aramaico babilônico quanto do aramaico palestino, contém toda a Torah, geralmente literal, mas com pequenas variantes textuais divergentes do TM. As edições da Bíblia Rabínica (Miqraot Guedolot) e a edição denominada Torá, a Lei de Moisés, em português, da editora Sêfer (FRIDLIN, 2001) trazem o texto do Targum de Ônquelos ao lado do texto hebraico.

Targum Pseudo Jônatas, também conhecido como Targum de Jerusalém I (TOV, 1992, p. 150) não antes dos séculos VII e VIII d.C. (FRANCISCO, 2008, p. 481), contém a Torah.

Targum de Jônatas Ben Uziel, séculos III e IV d.C., é um texto mais interpretativo que possui diferenças em relação ao TM, contém os textos de Josué à II Reis (Profetas Anteriores) e o texto de Isaías a Malaquias (Profetas Posteriores), (FRANCISCO, 2008, p. 484). ${ }^{206}$

Sobre o tipo de interpretação targúmica nos diz Browker (2009, p. 8):

A necessidade de encontrar formas de aplicar a revelação passada ao presente era inescapável, desde que esta foi a forma, frequentemente mais do que qualquer outra, de que a imediação de Deus poderia ser mantida em Israel. Isto, certamente, teve seus efeitos na tradução. Isto já é aparente na LXX; mas é muito mais aparente nos Targums. Os Targums, como a LXX, seguem o texto Hebraico verso a verso, mas eles incorporam em sua representação do texto uma grande quantidade de explanação e interpretação. Desta forma, o texto e sua interpretação são entrelaçados, e a interpretação frequentemente estende e amplifica o texto grandemente.

Os Targumim, são, desta forma, testemunhas de tradições interpretativas importantes para o entendimento do tipo de exegese, tanto anterior como posterior ao surgimento das correntes judaicas rabínicas, bem como do tipo de interpretação cristã primitiva; são 
testemunhas também na interferência das tradições interpretativas na produção de traduções "autorizadas" para determinadas comunidades alvo.

\subsection{Peshitta}

O nome Peshitta, "a <tradução> simples", foi usada para a tradução da Bíblia para o Siríaco, um dialeto do Aramaico. Este nome foi usado para distinguir a Peshitta da Siro-Hexapla (a tradução do grego da Hexapla para o Siríaco, preparada no sexto século por Paulo de Tella), desde que a língua daquela versão não era tão frequente. (TOV, 1992, p. 151-152)

Embora alguns estudiosos afirmem que a Peshitta tem elementos puramente cristãos, outros têm demonstrado elementos judaicos na versão, principalmente na Torah (TOV, 1992, p. 152).

Os debates sobre a origem da Peshitta ainda estão em aberto, bem como a data de sua origem (que geralmente tem sido estabelecida por volta do II d.C). A tradição, tanto cristã quanto judaica na Síria, é bem antiga, levando à conclusão de que ambas as tradições precisariam de uma versão da Bíblia Hebraica para o Siríaco em suas comunidades. De acordo com Tov (1992, p. 152), o manuscrito mais antigo da Peshitta data de 459-460 d.C.

Existem muitas variações no texto dos livros bíblicos e cada qual representa um tipo de tradução: Jó e Cântico dos Cânticos são literais; Isaías, Salmos, Rute e os doze Profetas são livres; Ezequiel e Provérbios são mais targum (interpretação) do que tradução e Crônicas é simples paráfrase. Não há consenso entre os estudiosos sobre qual foi a fonte para a revisão da Vetus Syra que resultou no surgimento da Peshitta. Alguns opinam que teria sido a LXX, outros acreditam que teria sido algum targum, enquanto outros admitem uma origem hebraica para a referida versão síria. (FRANCISCO, 2008, p. 498)

Um importante Pai da Igreja, de origem siríaca, conhecido como Ephraem, o sírio $(\dagger$ 373) cita largamente um tipo de texto siríaco, atestado no aparato crítico da Bíblia Hebraica Stuttgartensia como $\boldsymbol{S}^{\text {Aphr }}$. As edições da Peshitta, contudo, tem problemas para serem datadas para propósitos de crítica textual satisfatória (WÜRTHWEIN, 1994, p. 88).

Comparações das citações da Bíblia Hebraica feitas pela Peshitta no Novo Testamento demonstram que essa versão pode ter sofrido influência da mesma tradição dos targumim, pois em alguns textos o tipo de tradução é mais interpretativo. Alguns targumim posteriores, também podem ter usado o texto da Peshitta como base de tradução, ao invés de se utilizarem do texto hebraico. Sobre essa influência nos diz Miller e Huber (2006, p. 63): 


\begin{abstract}
Alguns dos livros da Peshitta, especialmente os do Pentateuco, revelam a influência de targuns em aramaico. No caso do livro de Provérbios, a fonte para a tradução do targum parece ter sido a Peshitta e não o texto em hebraico. As várias cópias da Peshitta permanecem consistentes, tornando o texto importante para ajudar a estabelecer a leitura correta no caso de textos hebraicos obscuros. Traduções do Novo Testamento foram adicionadas à Peshitta no segundo século. Atualmente, a Peshitta permanece como a Bíblia oficial das Igrejas Ortodoxas Síria e Maronita, bem como da Igreja do Oriente.
\end{abstract}

Após termos abordado as principais versões antigas da Bíblia Hebraica, veremos, nos próximos tópicos, como essas versões e outros textos da tradição judaico-cristã traduziram o texto de Is 52.13-53.12 e como as tradições interpretativas influenciaram essas traduções antigas. 


\section{Traduções Antigas do texto de Is 52.13-53.12}

É importante enfatizar que as antigas versões da Bíblia Hebraica estão mais próximas do que chamamos de interpretações ou comentários do que propriamente traduções. Produzidas para atender a comunidades especificas com tradições interpretativas já sedimentadas, as antigas traduções estavam menos preocupadas em repetir o texto hebraico do que dar a ele sentido para a comunidade a que se dirigiam

Colocamos lado a lado o texto das principais versões antigas, a LXX, o Novo Testamento, a Peshitta, a Vulgata e o Targum de Jônatas, com suas respectivas traduções. Faremos uma tradução e comentaremos os versículos que tiveram influências da tradição interpretativa.

\subsection{LXX}

\section{LXX (com base no texto de Rahlfs)}

\subsection{3}

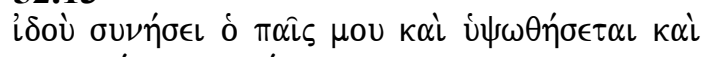
$\delta \circ \xi \alpha \sigma \theta \dot{\eta} \sigma \epsilon \tau \alpha \iota$ $\sigma \phi o ́ \delta \rho \alpha$

\subsection{4}

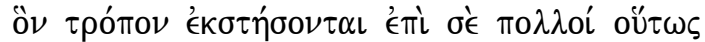

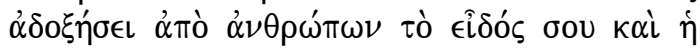

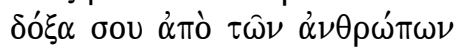

\subsection{5}

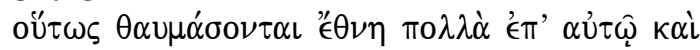

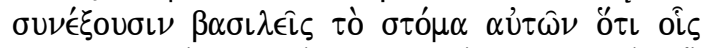

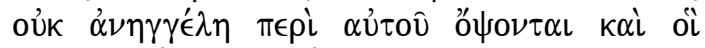

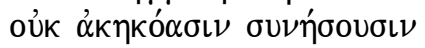

\section{1}

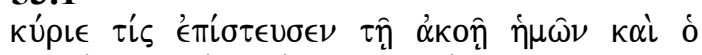

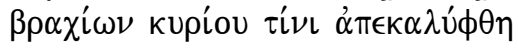

\section{Tradução ${ }^{207}$}

Eis que compreenderá, o meu servo, e será exaltado, e será glorificado grandemente.

Muitos ficarão espantados por ti, assim será desprezada dos homens a tua aparência e também [será desprezada] a tua glória dos homens.

Assim muitos povos se admirarão nele e reis também fecharão as suas bocas porque o que não foi anunciado para eles, verão, e aquilo que não foi ouvido por eles, compreenderão.

Senhor, quem creu na nossa mensagem e o braço do Senhor a quem foi revelado? 
53.2

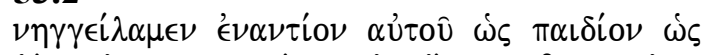

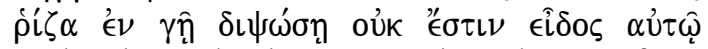

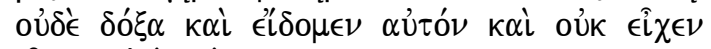

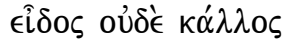

\section{4}

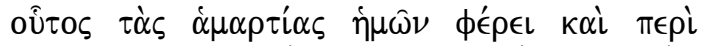

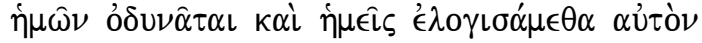

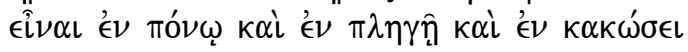

\section{$\mathbf{5 3 . 5}$}

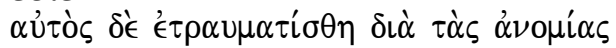

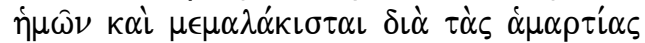

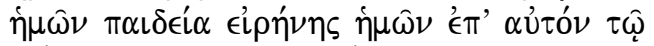

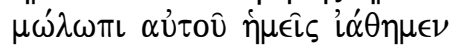

\section{6}

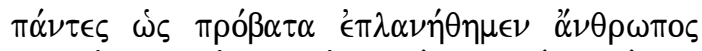

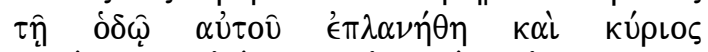

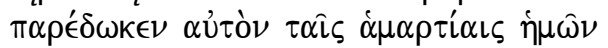

\section{7}

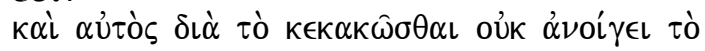

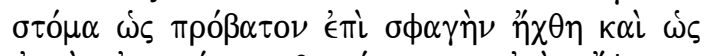

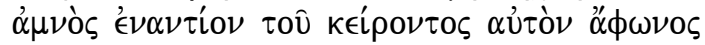

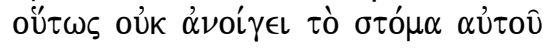

\section{8}

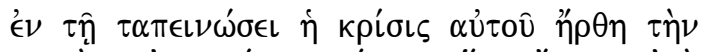

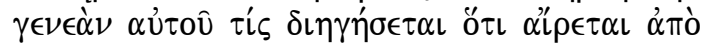

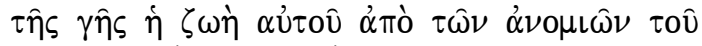

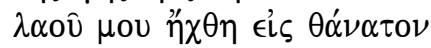

\section{9}

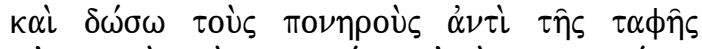

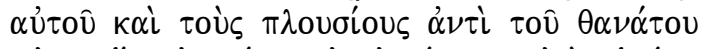

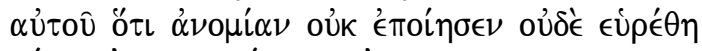

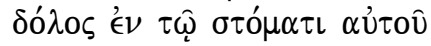

\subsection{0}

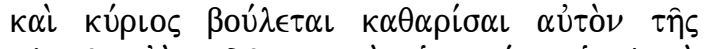

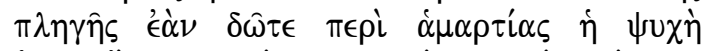

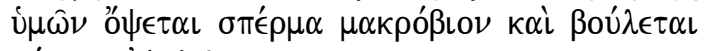
кúpเoৎ $\alpha \phi \in \lambda \in \hat{\epsilon} \nu$
Nós anunciamos diante dele, como uma criança, como uma raiz em terra seca não há aparência nele, nem glória, também o víamos e ele não tinha aparência nem beleza.

Ele carregou os nossos pecados e por nós sofreu agonia e nós o consideramos estar em dor e em praga e em opressão,

Mas ele foi ferido pelas nossas iniquidades e também foi enfraquecido pelos nossos pecados, uma correção da nossa paz sobre ele, no ferimento dele fomos sarados.

Todos como ovelhas éramos conduzidos, cada um no seu próprio caminho era conduzido, mas o Senhor o ofereceu pelos nossos pecados.

E ele, sendo maltratado, não abriu a boca, como ovelha que é conduzida para o abate, como cordeiro que fica mudo diante do seu tosquiador, assim não abriu a sua boca.

Em humilhação foi conduzido em sua condenação, sua geração, quem descreveu? Pois foi tomada da terra a sua vida, por causa do pecado do meu povo ele foi conduzido à morte.

E eu darei com os ímpios o seu enterro, mas com os ricos a sua morte, pois pecado não praticou e nem foi encontrado engano em sua boca.

E o Senhor quis purificá-lo do ferimento, quando vós destes, pelo pecado, a vossa vida, ele verá uma semente [de] longa vida e é do querer do Senhor cortá-lo. 


\subsection{1}

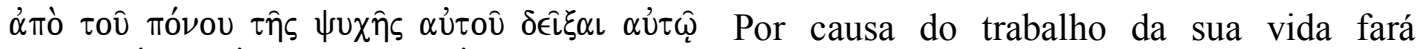

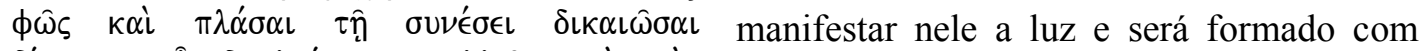

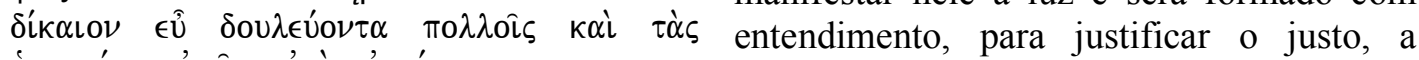

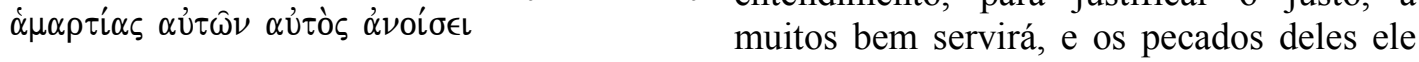
carregará,

\subsection{2}

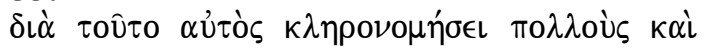

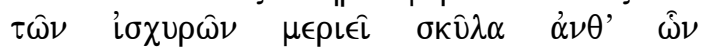

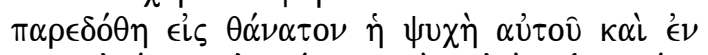

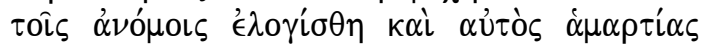

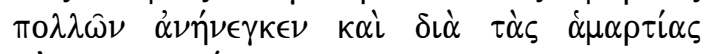
$\alpha \dot{\tau} \tau \omega \hat{\nu} \pi \alpha \rho \in \delta o ́ \theta \eta$

Por isso, ele herdará a muitos e com os poderosos repartirá os despojos, pois por entregar a sua vida para a morte, e pelas iniquidades ter sido contado, também ele, os pecados de muitos carregou, e pelos pecados deles foi entregue.

O texto da LXX que possuímos demonstra uma variação entre uma tradução literal em alguns versos e uma tradução mais interpretativa em outros. Indica, também, um Vorlage diferente do texto massorético, dificuldades do tradutor de entender o texto hebraico ou confusão com raízes parecidas, produzindo um texto ora confuso, ora estranho ao texto massorético.

No que se pode inferir da perícope da LXX acima exposta, nota-se que se afasta de uma interpretação do judaísmo posterior quanto a identidade do servo ser Israel, e se aproxima mais da interpretação cristã do servo ser uma pessoa que sofre para pagamento do pecado da nação de Israel.

A versão geralmente acompanha de perto o texto massorético, mas há momentos em que se torna diferente, inserindo elementos que dificilmente poderiam refletir um Vorlage semelhante ao do texto massorético. Em 53.6, temos uma variação importante o texto

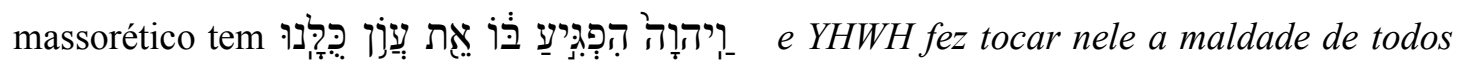

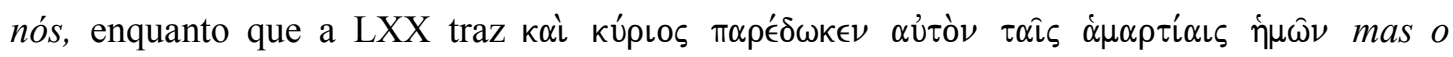
Senhor o ofereceu pelos nossos pecados, o que demonstra uma tradução interpretativa ou um Vorlage diferente do texto massorético. Em 53.10, há também uma construção estranha na

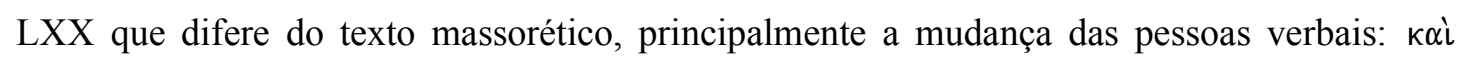

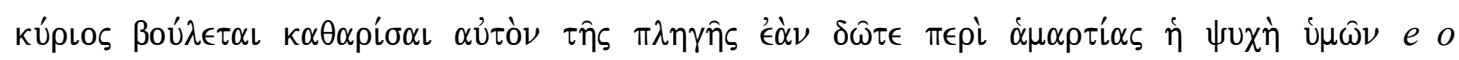
Senhor quis purificá-lo do ferimento, quando vós destes, pelo pecado, a vossa alma.., demonstrando uma interpretação ou a dificuldade do tradutor em entender o texto hebraico. Em 53.11, pode ter havido uma confusão na interpretação do verbo hebraico ele verá) com a raiz אור ('ôr = ser iluminado ou resplandecer) o que explicaria a inserção de 


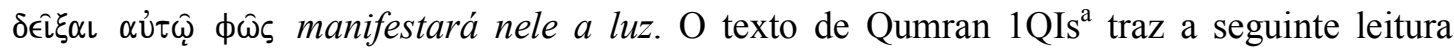
עי עיל נפשרח do trabalho de sua alma ele verá luz. ${ }^{208}$

O verso 53.12 pode trazer uma hipótese semelhante, pois a expressão hebraica אִחַלְק ('ahalléq = eu repartirei) é semelhante em sua raiz com ינחל (ynhal = ele herdará) o

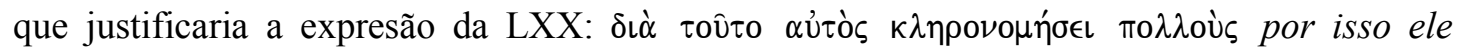
herdará a muitos.

Tendo em vista a complexidade da história da formação do que chamamos hoje de Septuaginta, a escassa quantidade de manuscritos pré-cristãos e a variedade de tradutores que produziram a tradução, pouco podemos inferir de seu texto, a não ser o que já foi dito anteriormente sobre as versões, que a LXX faz parte de uma tradição interpretativa mais do que uma tradução do texto hebraico.

\subsection{Novo Testamento 209}

\subsection{3}

NT $\quad$ Tradução $^{210}$

\section{At 3.13 (alusão)}

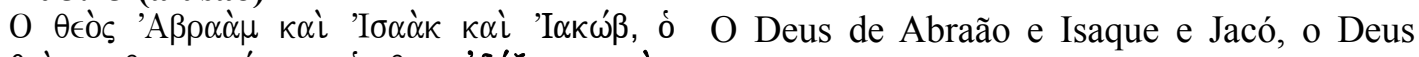

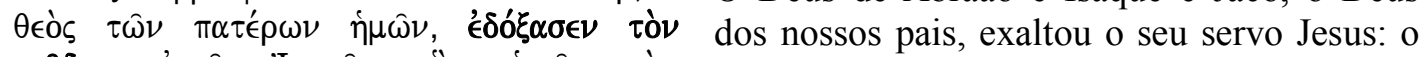

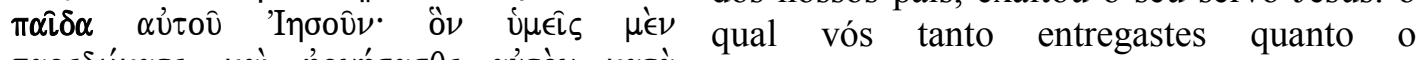

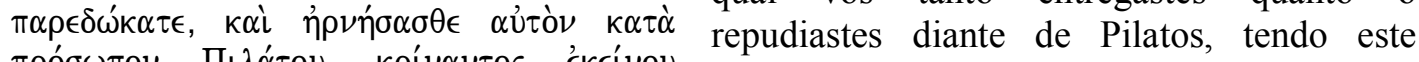

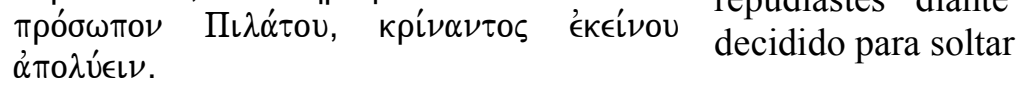

\subsection{4} Não há citação ou alusão para esse
versículo

\footnotetext{
${ }^{208}$ Observando a imagem do manuscrito de 1 QIs ${ }^{\text {a }}$, disponível em: $<$ http://dss.collections.imj.org.il/isaiah\#53:11>, nota-se que a linha logo acima tem a seguinte expressão: זרי נפשוח יראד o que pode ter causado um fenômeno chamado homeoteleuto (mesmo final), em que o escriba confundia finais parecidos, acrescido de uma confusão por causa da repetição de frases e letras semelhantes. Nessa hipótese, o escriba de Qumran e da LXX pode ter usado um mesmo Vorlage e o TM um Vorlage diferente.

${ }^{209}$ As citações neotestamentárias e alusões aqui citadas têm como base as referências cruzadas do texto grego do Novo Testamento da UBS quarta edição revisada (SBB, 2008, p. 745-760). Para facilitar a visualização coloquei em negrito as citações e alusões do texto grego do NT.

${ }^{210}$ As traduções do texto grego do NT são de nossa autoria.
} 


\subsection{5}

\section{Rm 15.21(LXX)}

$\dot{\alpha} \lambda \lambda \dot{\alpha} \kappa \alpha \theta \dot{\omega} \varsigma \quad \gamma^{\prime} \gamma \rho \alpha \pi \tau \alpha \iota^{\circ}$ ois oủk $\dot{\alpha} \nu \eta \gamma \gamma^{\prime} \in \lambda \eta$

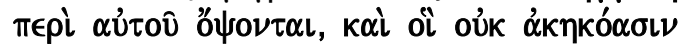

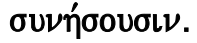

\section{Co 2.9 (alusão)}

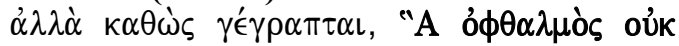

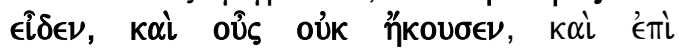

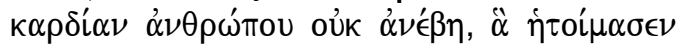

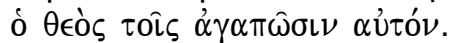

\section{1}

\section{Jo 12.38;}

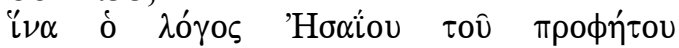

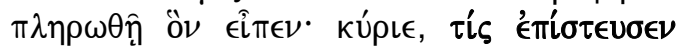

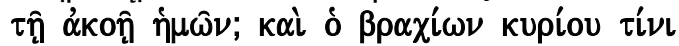
$\dot{\alpha} \pi \epsilon \kappa \alpha \lambda u ́ \phi \theta \eta$

\section{Rm 10.16 (LXX)}

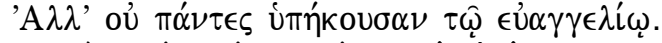

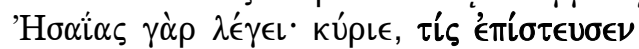

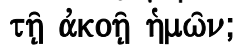

\section{2}

\section{3}

Mc 9.12 (alusão)

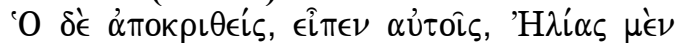
$\dot{\epsilon} \lambda \theta \dot{\omega} \nu \pi \rho \hat{\omega} \tau o \nu, \dot{\alpha} \pi 0 \kappa \alpha \theta \iota \sigma \tau \hat{\alpha} \alpha \alpha_{\alpha}^{\prime} \nu \tau \alpha \cdot \kappa \alpha \grave{\iota} \pi \hat{\omega} \varsigma$

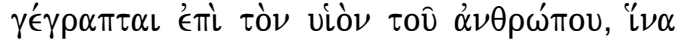

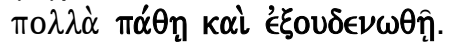

\section{4}

\section{Mt 8.17}

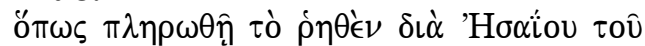

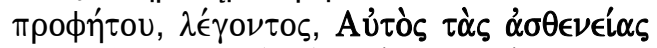

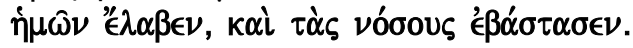

\section{Pe 2.24 (alusão)}

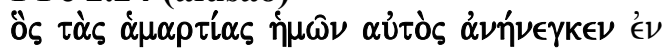

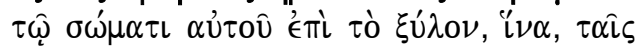

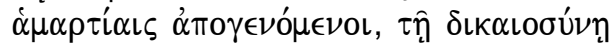

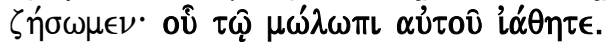

Mas como está escrito: aquilo que não foi anunciado a respeito dele será visto por eles, e o que não foi ouvido por eles, será entendido por eles.

Mas como está escrito, aquilo que olhos não viram, e ouvidos não ouviram, e ao coração do homem não subiu, aquilo que Deus preparou para os que o amam.

A fim de que a palavra do profeta Isaías se cumpra, a qual diz: Senhor, quem creu em nossa mensagem? E o braço do Senhor a quem foi revelado?

Mas nem todos obedeceram ao evangelho. Porque Isaías diz: Senhor, quem creu em nossa mensagem?

Não há alusão clara ou citação para esse versículo

Mas respondeu, disse-lhes, Elias vem primeiro, restaura todas as coisas, mas como está escrito a respeito do filho do homem, que deve sofrer muitas coisas e também ser desprezado?

De maneira que se cumpriu a palavra do profeta Isaías, que diz, Ele levou as nossas enfermidades, e as nossas doenças carregou.

O qual os nossos pecados ele ofereceu [como sacrifício] em seu corpo sobre o madeiro, a fim de que, os pecados fossem encerrados, para que por meio da justiça vivamos: que no sofrimento dele fostes sarados. 
Rm 4.25 (alusão)

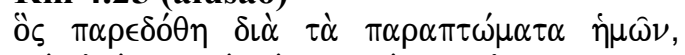

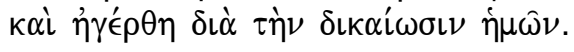

\section{6}

\section{At 10.43 (alusão)}

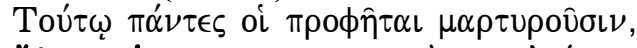

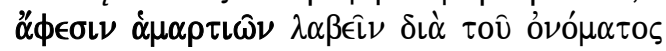

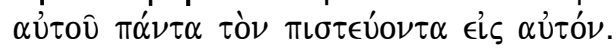

\section{Pe 2.25 (alusão)}

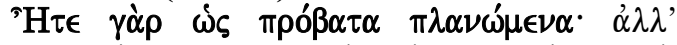

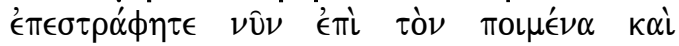

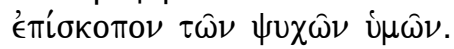

Jo 1.29 (alusão)

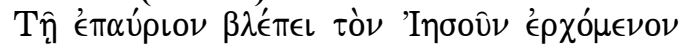

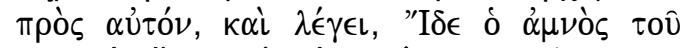

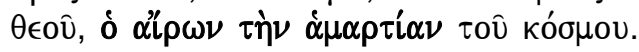

\section{7}

\section{At 8.32-33 (LXX)}

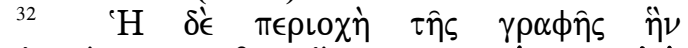

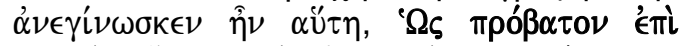

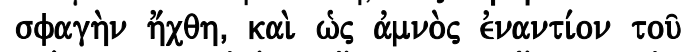

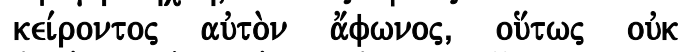

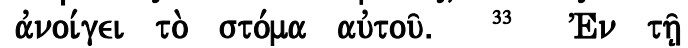

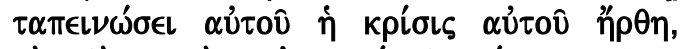

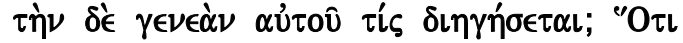

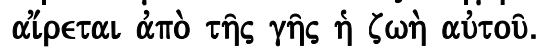

\section{Jo 1.29 (alusão)}

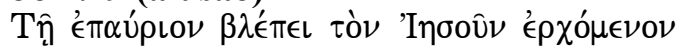

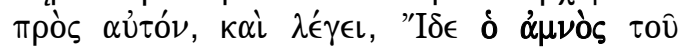

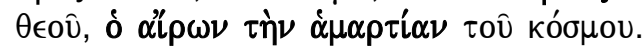

O qual foi entregue por causa das nossas transgressões, e foi ressuscitado para nossa justificação.
Dele, todos os profetas testemunham, a remissão dos pecados recebem, por meio do seu nome, todos os que creem nele.

Vós éreis como ovelhas desgarradas, mas agora voltastes ao pastor e bispo das vossas almas.

No dia seguinte, viu Jesus vindo a ele, e disse, Eis o cordeiro de Deus, o que carrega o pecado do mundo.

Mas a passagem da escritura que lia era esta, como ovelha levada ao abate, e como cordeiro que está mudo diante do que a tosquia, assim, não abriu a sua boca.

Em humilhação foi conduzido em sua condenação, mas sua geração, quem descreveu? Porque é levado da terra a sua vida.

No dia seguinte, viu Jesus vindo a ele, e disse, Eis o cordeiro de Deus, o que carrega o pecado do mundo.

\section{8}

At 8.32-33 (LXX)

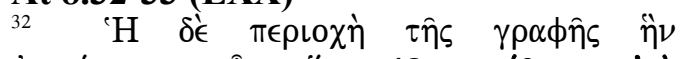

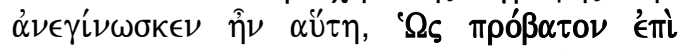

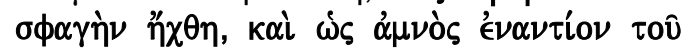

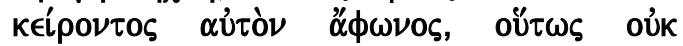

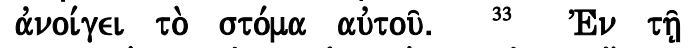

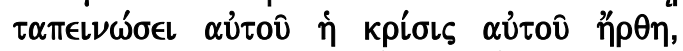

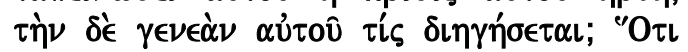

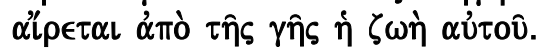

Mas a passagem da escritura que lia era esta, como ovelha levada ao abate, e como cordeiro que está mudo diante do que a tosquia, assim, não abriu a sua boca.

Em humilhação foi conduzido em sua condenação, mas sua geração, quem descreveu? Porque é levado da terra a sua vida. 
53.9

I Pe 2.22

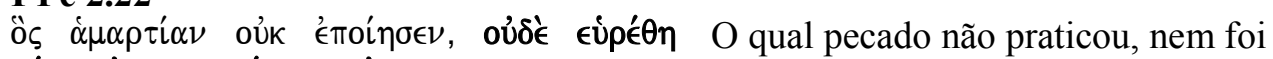

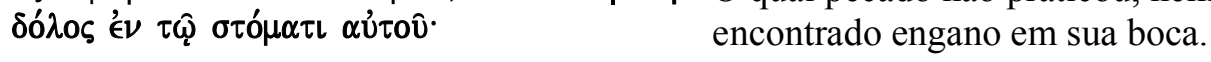

53.10

Não há citação ou alusão para esse versículo.

53.11

Não há citação ou alusão para esse versículo.

\subsection{2}

\section{Lc 22.37}

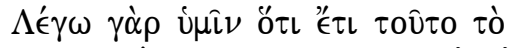

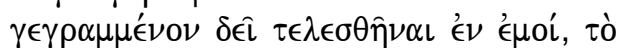

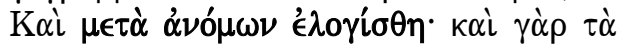

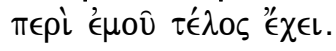

Porque vos digo que, ainda que, aquilo que está escrito, é necessário que se cumpra em mim, e com os malfeitores foi contado, pois ao meu respeito tem cumprimento.

O caso da tradução da Bíblia Hebraica encontrada no Novo Testamento é ainda mais complexo, pois há uma multiplicidade de textos e tradições interpretativas inerentes à sua produção. Longe de discutir os detalhes de sua produção, assim como na análise das outras versões, o trabalho se dá com o texto estabelecido pela tradição cristã e disponível nas edições modernas do texto grego.

Somente três passagens do NT seguem exatamente o texto da LXX que temos em mãos: Rm 15.21; Rm 10.16; At 8.32-33, todas as outras são alusões a Is 53 ou possíveis alusões, entretanto, todas as referências, quer sejam citações diretas, alusões ou possíveis alusões, têm propósitos interpretativos mais do que objetivos tradutórios.

Dentro da visão interpretativa do NT, podemos verificar que todas se relacionam com a pessoa de Jesus de Nazaré, aplicando a passagem de forma messiânica. O NT entende a esperança messiânica de acordo com as seguintes perspectivas: 1. Ele será exaltado (espiritualmente) Rm 15.21; 2. A mensagem da comunidade messiânica não será aceita, nem todos obedecerão ao evangelho (Jo 12.38); 3. Uma interpretação de um sentido oculto (sod), Nazaré como uma cidade desprezada e o Messias desprezado, Mt $2.23^{211}$, assim também em Mc 9.12 alude a 53.3 como se referindo ao desprezo do Messias; 4. O Messias carregaria as enfermidades do povo, Mt 8.17, citando 53.4, I Pe 2.24, Rm 4.25, At 10.43, Jo 1.29, At 8.3132, aludindo a 53.4; 5. O povo andava como ovelha desgarrada, I Pe 2.25 aludindo a 53.6; 6. O Messias seria vítima inocente, I Pe 2.22, Lc 22.37, aludindo a 53.9, 12.

${ }^{211}$ Para uma excelente explicação dessa citação controversa de Mt 2.23 ver Geisler e Howe (1999, p. 205). 


\subsection{A Peshitta}

52.13-15

$$
\text { Peshitta }^{212}
$$

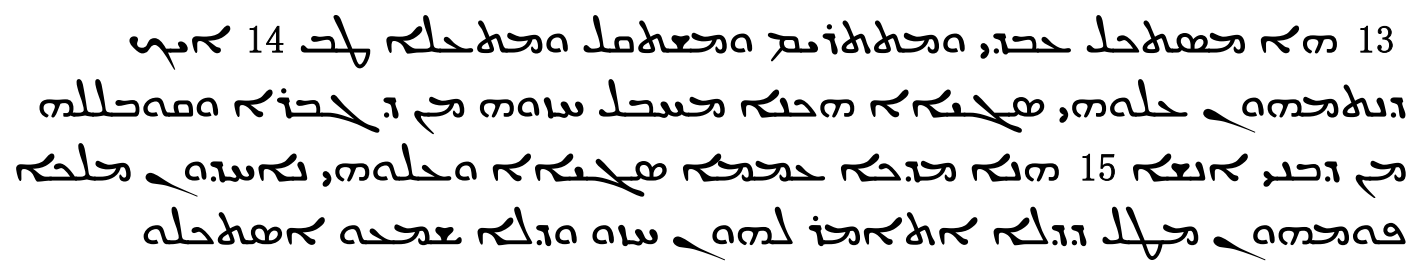

13 hä' mestakal 'avdy w' mettarîm wmeštaqal wmet la' tậ

14 'ayk dnetmhun 'alwhy sagaia" hakana' mḥabel hẹwēh min ragvda' wquvlaleh min ravny 'anaša'

15 hana' mdaka' 'amme' sagaya'a' w'alwhy ne'ḥdaun malka' pumhon mețl dedla' 'et'mar lhon hzw odla' šma'nw'estklw

\section{Tradução:}

13 Eis que meu servo entenderá e ele será exaltado e enaltecido, e será muito elevado.

14 Muitos ficaram impressionados com ele; pois sua aparência estava desfigurada mais do que qualquer homem e sua figura mais do que a dos filhos dos homens.

15 Eis que ele purificará muitas nações; reis fecharão as suas bocas por causa dele, pois aquilo que não lhes tinha sido dito eles verão.

\section{1-3}

53

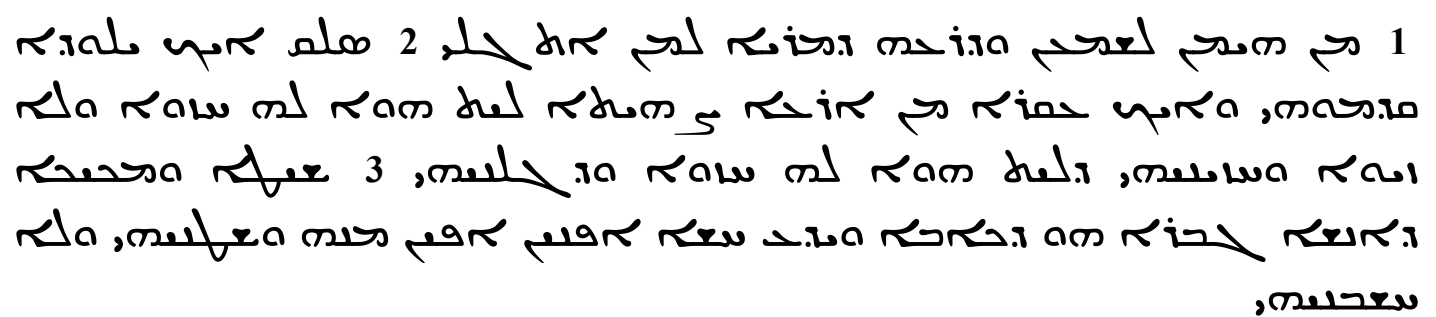

1 măn haymen lšema'an odr'eh dmerya' lman 'etgaly

\footnotetext{
212 O texto fonte da Peshitta digitalizado é o disponibilizado em: $<$ http://cal1.cn.huc.edu/searching/targumsearch.html $>$ acesso em: 20 fev. 2012. Utilizamos como base da tradução da Peshitta o texto traduzido para o inglês disponível em:

$<$ http://www.aramaicpeshitta.com/OTtools/LamsaOT/23 isaiah.htm> acesso em: 12 fev. 2013, fizemos algumas adaptações quando achamos necessárias. Para a transliteração utilizamos o texto vocalizado da Trinitarian Bible Society, 1913.
} 
2 sleq 'ayk yaluda' qdamawhy w’ayk 'eqara' min 'ar'a' tshyta' layt hawa' leh hezw' wla' zyw' uḥzaynayhy dlayt haw' leh ḥzw' wdglnyhy

3 šyța' wmakayka' d'naša' gavra' haw dka'ba' wyda' haša' 'afnyn 'afyan meneh wšețnayhy wla’ ḩšabnayhy

\section{Tradução:}

53.1 Quem creu em nossa pregação e o braço do Senhor a quem se revelou?

53.2 Pois foi crescendo diante dele como uma criança e como raiz de uma terra seca. Ele não tinha parecer nem formosura e, quando vimos que ele não tinha beleza, nós o negamos.

53.3 Era desprezado e o mais humilde dos homens; um homem de dores e experimentado no sofrimento, e nós viramos o nosso rosto em sentido contrário a ele; nós o desprezamos e não fizemos caso dele.

\section{4-6}

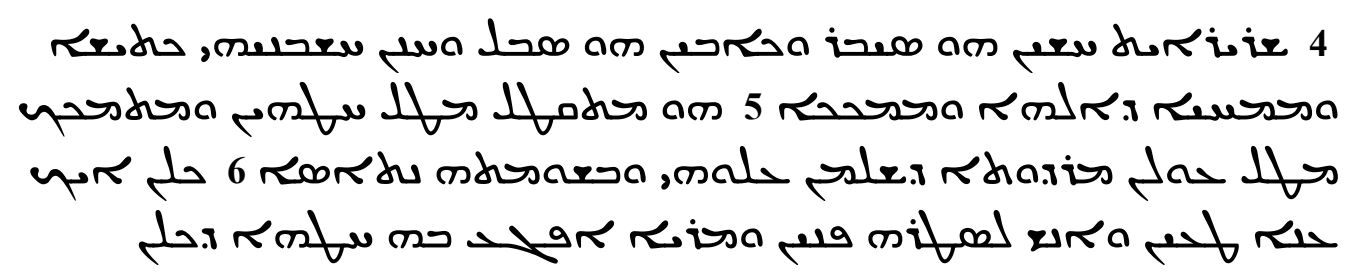

4 šaryar'yt hašayan haw sayvar wka'bayan haw sval uḥnan ḥ̌̌avnayhy ktyaša’ ummaḥya' d'alaha' ummakaka'

5 haw metqțel mețal hațhayan wmetmakka' mețl 'auna' madruta' dašalaman 'alwhy uvšadamateh net'ase'

6 klan 'ayk 'ana' țanayn w’naš lsețrah pnayn wmarye' 'afege beh ḥțahe' dkalan

\section{Tradução:}

53.4 Verdadeiramente ele tomou sobre si as nossas dores e carregou as nossas dores, mas nós o consideramos por aflito, ferido de Deus e afligido.

53.5 Mas ele foi morto por nossos pecados, ele foi afligido por nossas iniquidades, o castigo que nos traz a paz estava sobre ele, e pelas suas pisaduras fomos sarados.

53.6 Todos nós, como ovelhas, tínhamos nos desviado, cada um para seu próprio caminho; e o Senhor fez cair sobre ele os pecados de todos nós. 


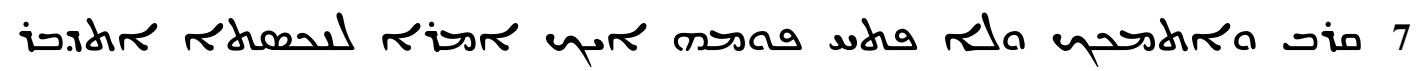

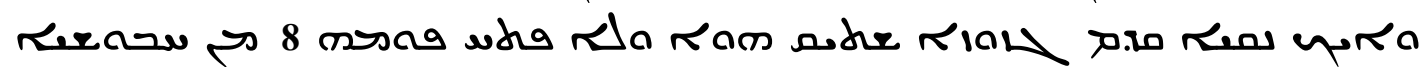

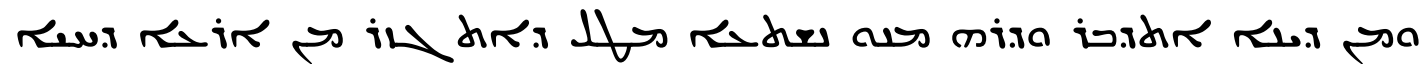

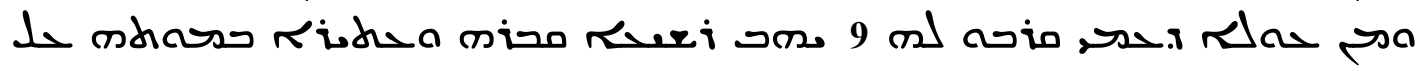

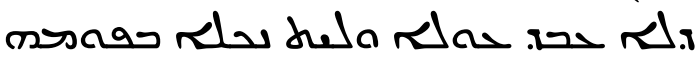

7 qrev w'etmakak wla' ptah pumeh 'ayk 'emar' lneksta' 'etdvar w'ayk neqya' qdam gezoza' šatyq hao' wla' ptah pumeh

8 man ḥvušya' wman dyna 'etdvar wdarah manu nešt'e' mețl d'etgzar man 'ar'a' dhaya' wman 'aole' d'amy qdavw leh

9 yahav rašy a' qvreh w'atyra' bmawteh 'al dla' 'avad 'aula' ulayt nekla' bfumeh

\section{Tradução:}

53.7 Ele se aproximou e foi angustiado, porém, não abriu a sua boca, ele foi levado como um cordeiro ao matadouro, e como uma ovelha que diante dos seus tosquiadores fica muda, assim, ele não abriu a sua boca.

53.8 Ele foi tomado da prisão e do julgamento; e quem pode descrever a sua angústia? Pois ele foi cortado da terra dos viventes; e alguns dos homens maus do meu povo feriram-lhe.

53.9 Ele colocou a sua sepultura com os ímpios, e com o rico na sua morte, embora nunca tivesse cometido injustiça, nem houve engano em sua boca.

53.10-12

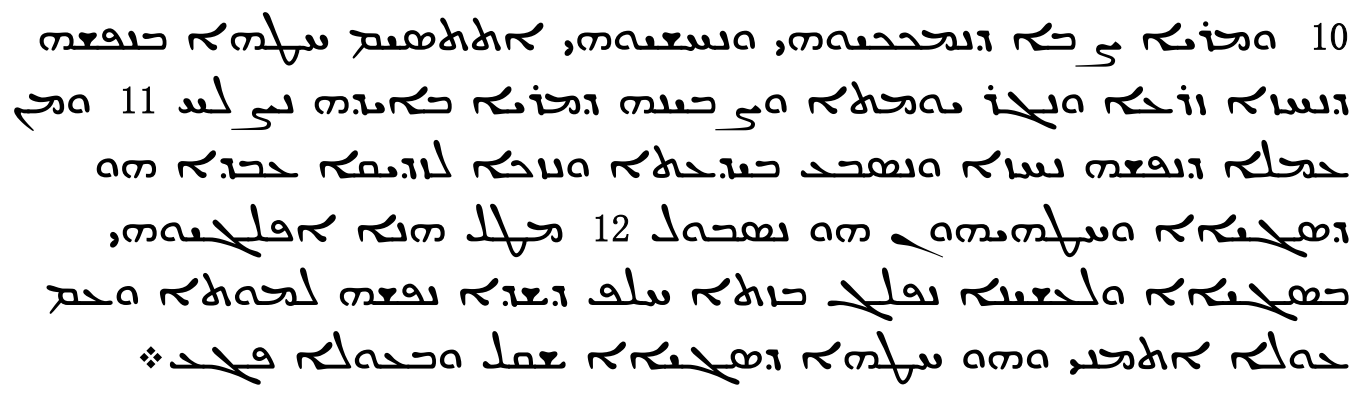

10 wmarya' tsva' denmakakywhy wnyhšywhy 'ettsym ḥṭaha' bnafšeh dneḥze' zara' wnagar yaomata' wtsvyneh dmarya' b'ydeh natslah

11 wman 'amla' dnafšeh nehze' unsava byd'te' unzake' lzadyqe' 'avda' haw dsagay'a' 
uhțahayahon hew nesvol

12 mețl hana' 'efalgywhy bsagay'a' ul'ašyne' nfaleg bezte' ḥlaf dešde' nafšeh lmawta' w'am 'aole" etmeny whew hṭahe' dsagay'a' šqal uva'ole' pga'

\section{Tradução:}

53.10 Mas foi do agrado do Senhor afligi-lo, ele o destinou à tristeza, ele deu a sua vida como oferta pelo pecado, para que a posteridade veja, e para que os seus dias sejam prolongados, e o prazer do Senhor prosperará.

53.11 Ele verá a recompensa do trabalho da sua alma e estará satisfeito, com o seu conhecimento ele justificará os justos, um servo de muitos, e ele carregará os seus pecados.

53.12 Pelo que lhe darei o seu quinhão com os grandes, e repartirá ele o despojo com os fortes, porquanto ele derramou sua vida até a morte, e foi contado com os transgressores, e ele levou os pecados de muitos, e morreu a morte dos transgressores.

A Peshitta segue de perto o texto massorético com ligeiras modificações, é a menos interpretativa das versões. Porém, algumas passagens da Peshitta são importantes, Is 52.15, ao invés de espalhar, espantar, aspergir, traz purificar, relacionando com os contextos de purificação que ocorrem em levítico (Lv 4.6; Lv 5.9). Em 53.1 a expressão: nós o negamos, que pode dar a impressão de uma rejeição ao Servo. Em 53.8 há uma interpretação: e alguns dos homens maus do meu povo feriram-lhe, o que também evidencia uma distinção entre o povo e o Servo que sofre. À parte dessas passagens, não há grandes diferenças entre a versão siríaca e o TM.

\subsection{A Vulgata ${ }^{213}$}

\section{Vulgata (conforme o texto da Deutsche Bibelgesellschaft, 2007)}

\subsection{3}

ecce intelleget servus meus exaltabitur et elevabitur et sublimis erit valde

\subsection{4}

sicut obstipuerunt super te multi sic Assim como pasmaram sobre ti muitos, assim inglorius erit inter viros aspectus eius et sem glória será entre os homens seu aspecto, forma eius inter filios hominum

\section{Tradução}

Eis que terá compreensão o meu servo, será muito elevado e sublime. e sua forma entre os filhos dos seres humanos.

\footnotetext{
${ }^{213}$ Utilizamos como base a tradução de Matos Soares (BÍBLIA. Português. Bíblia Sagrada Edições Paulinas, 1980) com ligeiras alterações.
} 


\subsection{5}

iste asperget gentes multas super ipsum continebunt reges os suum quia quibus non est narratum de eo viderunt et qui non audierunt contemplati sunt

\section{1}

quis credidit auditui nostro et brachium Domini cui revelatum est

\section{2}

et ascendet sicut virgultum coram eo et sicut radix de terra sitienti non est species ei neque decor et vidimus eum et non erat aspectus et desideravimus eum

\section{3}

despectum et novissimum virorum virum dolorum et scientem infirmitatem et quasi absconditus vultus eius et despectus unde nec reputavimus eum

\section{4}

vere languores nostros ipse tulit et dolores nostros ipse portavit et nos putavimus eum quasi leprosum et percussum a Deo et humiliatum

\section{5}

ipse autem vulneratus est propter iniquitates nostras adtritus est propter scelera nostra disciplina pacis nostrae super eum et livore eius sanati sumus

\section{6}

omnes nos quasi oves erravimus Todos nós como ovelhas andamos unusquisque in viam suam declinavit et desgarrados em seus caminhos; o Senhor
Ele espantará muitas nações e reis fecharão as suas bocas para ele. Pois o que não tinha sido dito a eles verão, e o que não ouviram contemplarão.

Quem deu crédito ao que nós ouvimos? E o braço do Senhor a quem foi revelado?

Ele subirá como arbusto diante dele, e como raiz que sai de terra seca; ele não tem beleza, nem formosura; e vendo-o, não era do aspecto que desejávamos.

Era desprezado e último dos homens, homem de dores, e conhecedor dos sofrimentos; e o seu rosto estava encoberto; por isso não fizemos dele caso algum.

Verdadeiramente, carregou as nossas próprias dores e nós pensávamos dele como se fosse leproso, e perseguido de Deus e humilhado.
Ele foi ferido por causa das nossas iniquidades, foi despedaçado por causa dos nossos crimes; a instrução da nossa paz [estava] sobre ele e pelas pisaduras dele somos sarados. 
Dominus posuit in eo iniquitatem omnium carregou nele a iniquidade de todos nós. nostrum

\section{7}

oblatus est quia ipse voluit et non aperuit os suum sicut ovis ad occisionem ducetur et quasi agnus coram tondente obmutescet et non aperiet os suum

\section{8}

de angustia et de iudicio sublatus est generationem eius quis enarrabit quia abscisus est de terra viventium propter scelus populi mei percussit eum

\section{9}

et dabit impios pro sepultura et divitem pro morte sua eo quod iniquitatem non fecerit neque dolus fuerit in ore eius

\subsection{0}

et Dominus voluit conterere eum in infirmitate si posuerit pro peccato animam suam videbit semen longevum et voluntas Domini in manu eius dirigetur

Da angústia e do juízo foi tirado. A sua geração quem contará? Porque ele foi cortado da terra dos viventes; por causa da maldade do meu povo o feriu.

Foi oferecido porque ele mesmo quis, e não abriu a sua boca; como uma ovelha que é levada ao matadouro, como um cordeiro diante do que o tosquia, ficou em silêncio e não abriu a sua boca.

E dará os ímpios em recompensa da sua sepultura e o rico em recompensa da sua morte; porque ele não cometeu iniquidade, nem nunca se achou dolo na sua boca.

O Senhor quis consumi-lo em sofrimentos, mas, quando tiver oferecido a sua vida pelo pecado, verá uma descendência perdurável, e a vontade do Senhor nas suas mãos prosperará.

\subsection{1}

pro eo quod laboravit anima eius videbit et saturabitur in scientia sua iustificabit ipse iustus servus meus multos et iniquitates eorum ipse portabit

\subsection{2}

ideo dispertiam ei plurimos et fortium dividet spolia pro eo quod tradidit in morte animam suam et cum sceleratis reputatus est et ipse peccatum multorum tulit et pro transgressoribus rogavit

Verá o fruto pelo qual sua alma trabalhou e ficará satisfeito. Esse mesmo justo, meu servo, justificará muitos com seu conhecimento, e tomará sobre si as suas iniquidades.

Por isso, the darei por sorte uma grande multidão e ele distribuirá os despojos dos fortes, porque entregou sua vida na morte e com os malfeitores foi posto, e tomou o pecado de muitos e intercedeu pelos pecadores.

A Vulgata também não traz grandes diferenças com o texto massorético, porém, algumas 
passagens são significativas: 53.4 traz uma interpretação da expressão considerávamos ferido por et nos putavimus em quasi leprosum e nós pensávamos dele como se fosse leproso, conforme Sanhedrin $98 \mathrm{~b}^{214}$. É conhecido o fato de Jerônimo ter estudado com rabinos e aconselhado consultá-los em caso de dúvidas com o texto hebraico. Essa expressão, portanto, é explicada pela influência rabínica de sua época na tradução do texto.

O verso 53.7 também tem um acréscimo ausente no TM, A Vulgata acrescenta a expressão: oblatus est quia ipse voluit ele foi oferecido porque ele mesmo quis.

Em 53.8 há uma diferença em relação ao TM no final do versículo, a Vulgata traz "percussit eum" o feriu, o que pode ser explicado pela dificuldade de ajustar a expressão final למו para ele[s], que pode ter tido uma leitura diferente no Vorlage da Vulgata, possivelmente לו para ele.

\title{
6.5 Targum de Jônatas ${ }^{215}$
}

\author{
Targum de Jônatas ${ }^{216}$
}

52.13

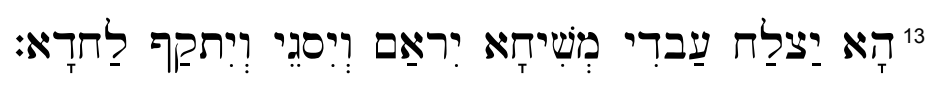

hâ' yatslah 'avdî mešlhâa' îr'am wê̂sgêy weîtqaf laḥdâ’

Eis que prosperará meu servo, o Messias, será grande e será forte e muito poderoso

52.14

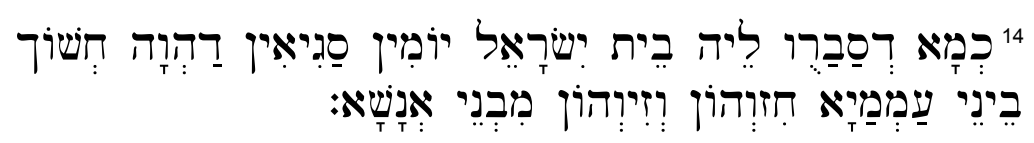

$\underline{k}^{\mathrm{e}}$ mâ' d ${ }^{\mathrm{e}}$ savaruw leyh vêyt îśrâ' êl yômîn sagî' în dahwâh ḥ̣ šôk

vêynêy 'am 'mayâ' ḥzw hôn w'ḥzw' hôn mivnêy 'nâšâ'

Assim como espera por ele, a casa de Israel, muitos dias, que era escuridão entre os povos sua aparência, e seu brilho mais do que os filhos do homem.

\footnotetext{
214 Ver a passagem completa e tradução no capítulo seguinte.

215 O texto fonte é o disponibilizado no software Bible Works 7.0. Para auxílio de tradução, estamos utilizando como base, a versão para o inglês feita por C. W. H. Pauli (PAULI, 1871, p. 181-185) com algumas alterações.

216 Para não embaralhar o texto aramaico, colocamos tradução abaixo do texto.
} 
52.15

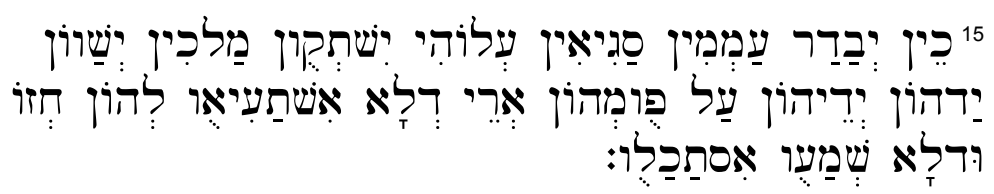

kêyn yevadar 'm mîn sagîîn 'lôhî î̌št ${ }^{e}$ quwn malkîn y šwôn yadhôn y dêyhôn 'al fuwmehôn 'rêy delâ' 'išta y'înuw lehôn hịô ûdlâ' šema'uw istakaluw

Assim espalhará muitos povos sobre ele, reis silenciarão, colocarão as suas mãos sobre as suas bocas, por causa do que não foi contado a eles viram, e o que não ouviram, eles entenderam.

53.1

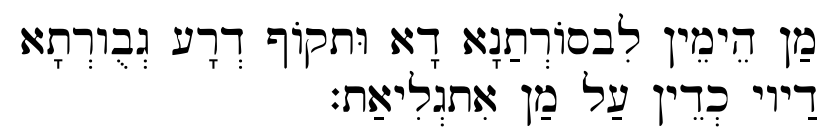

man hêymêyn livsôrtanâ' dâ' ûtqôf d'râ' gevuwrtâ'

daywy $\underline{k}^{\mathrm{e}}$ dêy 'tal man 'itg' ${ }^{\mathrm{e}} \mathrm{lîa}^{\mathrm{a}}$

Quem acreditou em nossa mensagem? E esta força do braço forte de YWY, então, sobre quem foi revelada?

53.2

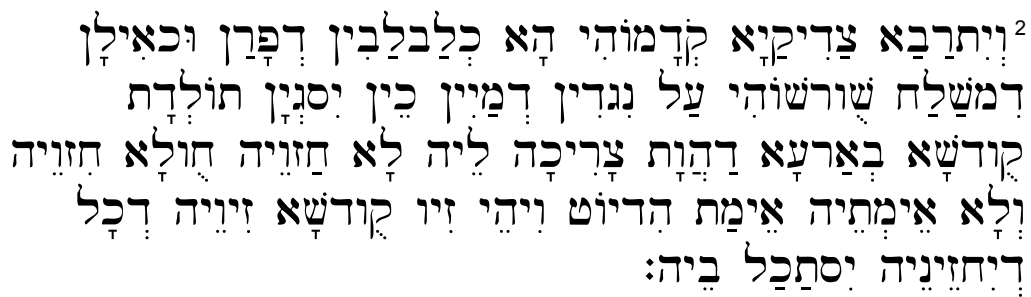

weîtraba' tsadîqayâ' q dâmôhî hâ' ḱ lavlavîn d'eâran ûk'îlân

dimšalah šuwršôhî 'al nigdîn demaîyn kêyn îsg yân tôledât

quwdšâ' v'ar'â' daháwât tsârîkâh lêyh lâ' hạawêyh hụulâ' ḥzwêyh

welâ' 'êym têyh 'êymat hidyôt wîhêy zîw quwdšâ' zîwêyh d'kâl

dềhzêynêyh îstakal vêyh

Aumentará a justiça diante dele, eis que como a flor que floresce e como a árvore que espalha suas raízes sobre o caminho de águas, assim será a santa geração na terra que tinha necessidade dele não [terá] visão de aspecto profano e não [terá] temor de um tolo, a [sua] santa aparência [será] esplendorosa e todo o que o ver perceberá [estas coisas] nele.

53.3

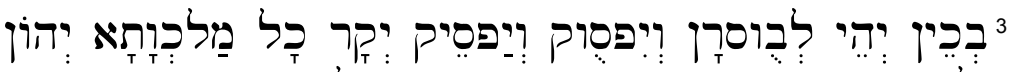

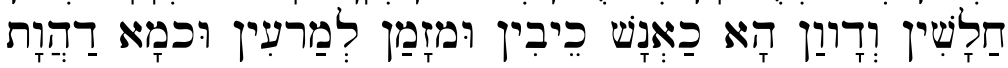




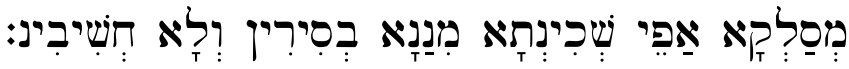

$v^{e}$ kêyn y $y^{e}$ êy levuwsrân weîfsuwq weyafsêyq y qâr kâl malkwâtâ' y hôn halâšîn wedâwwan hâ' ka'nâš kêyvîn ûmzâman lemar în ûkmâ' daháwât mesalqầ' 'afêy škîntâ' minanâ’ ve sîrîn w'lầ ḥ̌šivîn

Então, ele será por desprezo, e quando for cortado, será cortada a majestade, todo o reinado será fraco e a fraqueza, eis que [será] como a de um homem doente e preparado como enfermidade e também será como o que é removido as faces da glória em desprezo e não sem consideração.

\section{4}

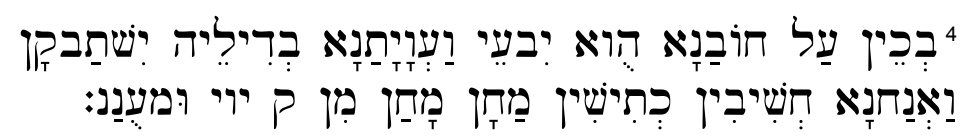

veekeyn 'al ḥôvanâ’ ve dîlêyh îštavqân wa’naḥnâ' ḥšîvîn ktî̌sîn maḥân maḥân min q ywy ûm'unan

Então, a respeito do nosso pecado ele rogará e a nossa ofensa por causa dele será levada, e nós reputávamos como malditos, extremamente ferido de YWY e aflito

\section{5}

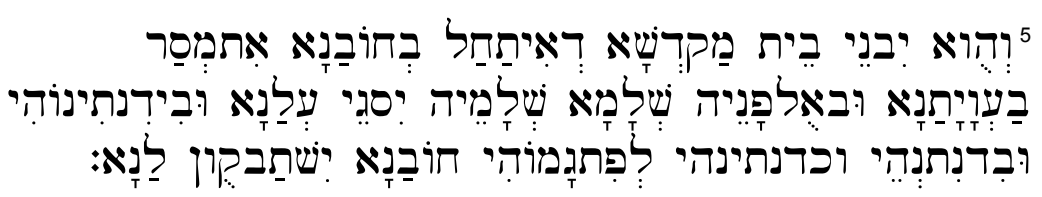

w'huw' îvnêy bêyt maqdšâ' d 'îtahal v' họvanâ' 'itm 'sar va wâyâtanâ' ûv'ulfânêyh šelâmâ' še lâmêyh îsgêy 'lanâ' ûvîdintînôhî ûvidnitnhêy wkdntynhy lefitgâmôhî hôvanâh î̌stavquwn lanâ’

E ele edificará o templo [a casa de santidade] que foi profanada por nosso pecado, [ele] remirá a nossa iniquidade e em sua doutrina da paz, paz se multiplicará para nós, e por causa do seu clamor e dos clamores que clamar as palavras dele, nosso pecado será levado diante de nós.

53.6

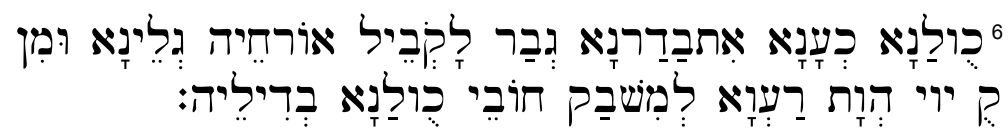

kuwlanâ' k ânầ 'itvadarnâ' g var lâq'ovêyl 'ôrhẹyh g lêynâ' ûmin qu ywy hwât ra'wâ' l'mišvaq hôvêy kuwlanâ' v' dîlêyh 
Todos nós como a ovelha nos dispersamos, cada um de acordo com seu próprio caminho do exílio; e era da vontade de YWY permitir os pecados de todos nós [fosse levado] por causa dele.

53.7

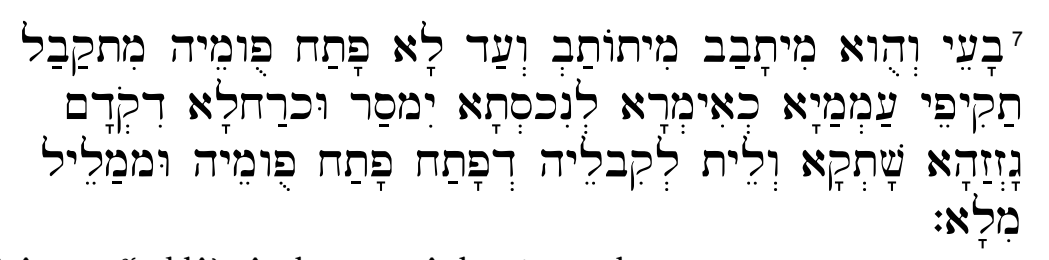

vâêey w'huw' mîtâvav mîtôtav wee ad lâ’ pâtah puwmêyh mitqaval

taqîfêy 'ammayâ' k'îm ${ }^{e}$ râ' leniks 'tầ îmsar ûkrahlâ' diqôdâm

gâzzahâ' šâtqâ' ' w'lêyt l'eqivlêyh defâtah pâtah fuwmêyh ûmmalêyl

milầ

Ele clamará e ele obterá resposta, [ainda] em silêncio e até [antes] de abrir a sua boca receberá [resposta]; as forças dos povos como cordeiro para o sacrifício, e como ovelha que é condenada e diante do que o sacrifica está em silêncio e abrindo a sua boca [não] diz palavra.

53.8

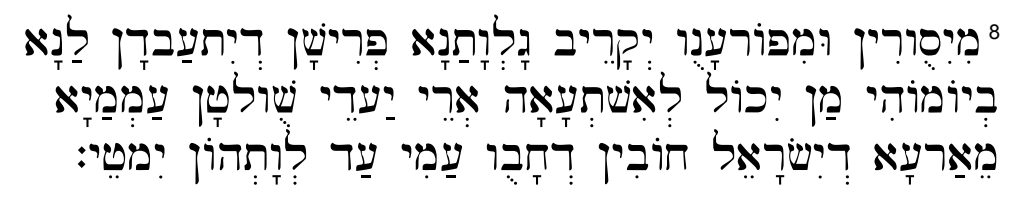

mîsuwrîn ûmipôr ânuw yeqârîv gâlwâtanâ’ perîšân deît vdân lanâ’

$v^{e}$ yômôhî man îkôl l'e'š̌t 'â'âh 'rêy ya 'dêy šuwltân 'ammayâ'

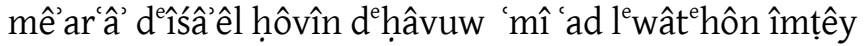

Sofrimentos e nossas punições receberá [por] nossos exilados, sacrifício de adoração [será] para nós, em seus dias, quem pode narrar? Porque obteve vitória dos povos da terra de Israel. O pecado que pecou o meu povo até ele chegou.

53.9

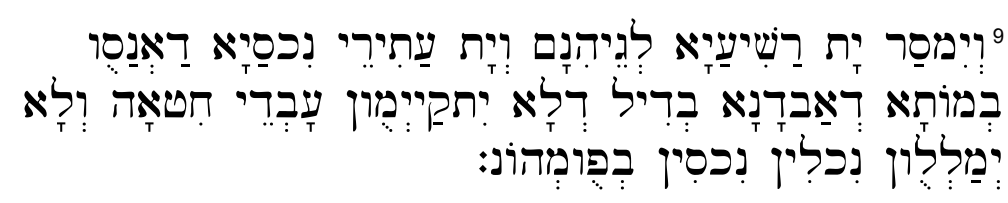

w'îmsar yât rašî́ayâ’ legêyhinâm weyât 'atîrêy niksayâ’ da’nasuw $v^{e}$ môtâ' d'a avdânâ' v' dîl delâ' îtqayy ${ }^{e}$ muwn 'âvdêy hițâh w'lâa' $y^{e}$ malluwn niklîn niksîn $v^{e}$ puwm ${ }^{e}$ hôn 
E ele entregou os malvados ao geena, e os bens dos ricos que foram tomados pela violência da nossa destruição, de maneira que não permaneceram os atos de pecado e não [foram] consideradas as multidões de culpas em suas bocas.

\subsection{0}

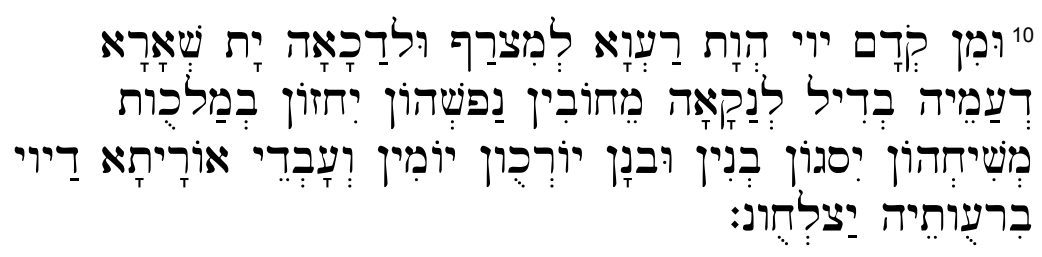

ûmin qodâm ywy hwât ra 'wâ' le mitsraf ûldakââh yât šêa ârâ’

d'amêyh v dîl l $1^{\mathrm{e}}$ naqââh mêhôvîn nafš hôn îhzôn v'malkuwt

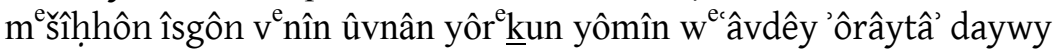

viruwtêyh yatsl ḥuwn

E esta era a vontade de YWY refinar e purificar o restante do seu povo, de maneira que a purificação dos pecados da alma deles seja visto no messias deles, e multipliquem-se os filhos e as filhas e aumentem os dias, e as obras da lei de YWY por meio de sua vontade prospere.

\subsection{1}

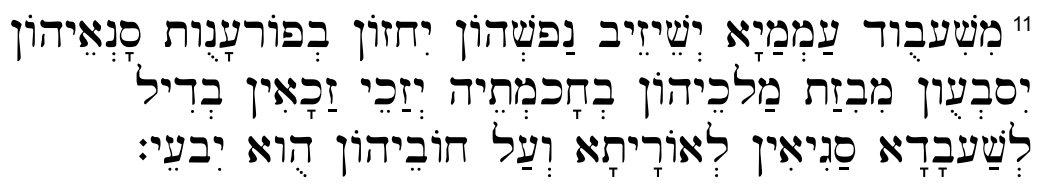

mišcvuwd 'ammayâ' y ěsêyzêyv naf šhôn îḥzôn vefôr ânuwt sân'êyhôn

îsvecuwn mivizat malkêyhôn v $v^{e} h a ̂ k m^{e}$ têyh yezakêy zakââin v'dîl

leša vâdâ’ sagîîn le’ôrâytâ’ w'a'l hị̂vêyhôn huw' îv êy

Do serviço dos povos salvará a alma deles. Eles verão a retribuição dos seus inimigos, ficarão satisfeitos pelos espólios dos seus reis, na sabedoria dele, ele justificará os justos, de maneira que servirão muitos a lei e pelos pecados deles ele clamará.

53.12

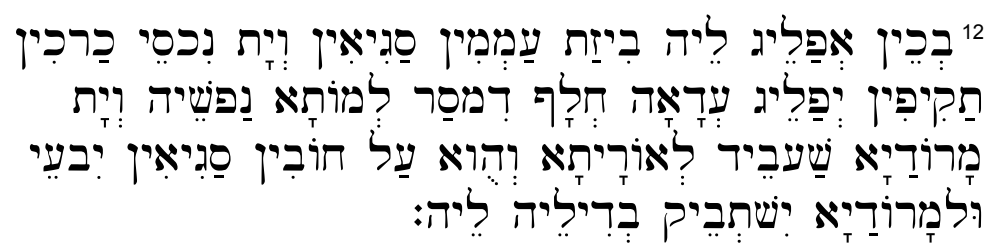

v'kêyn 'falêyg lêyh vîzat 'ammîn sagîîn w'yât niksêy karkîn taqîîn y falêyg 'dâ'âh ḥlâf dimsar lemôtâ' nafšêyh weyât mârôdaî ša vêyd leôrâytâ' w'huw' 'al hôvîn sagîn în îv'êi 
ûlmârôdaîâ' îšt ${ }^{e}$ vêyq vedîlêyh lêyh

Então, eu dividirei com ele o espólio de muitos povos e os bens das cidades fortes. Ele dividirá os espólios, porque ele entregou sua alma na morte, e, aos rebeldes, ele fará obedecer a lei. E ele, a respeito dos pecados de muitos clamará e por causa dele [os pecados] dos rebeldes serão levados

O texto do Targum, é, sem dúvida, o mais interpretativo, a inserção de palavras em vários momentos do texto, tem o objetivo de explicar mais do que traduzir. Já em 52.13, a inserção do termo עשיח Messias, em aposto à expressão servo, evidencia que a passagem teve uma interpretação messiânica dentro da tradição judaica. Diferente da interpretação mais comum na tradição rabínica, de que o servo é Israel, o targum faz clara distinção entre o servo e Israel em várias passagens $(52.14 ; 53.5 ; 53.8 ; 53.10)$.

Por causa das muitas interpretações é praticamente impossível inferirmos se o Vorlage do Targum é o mesmo do TM. É um texto importante para o estudo das tradições paralelas àquelas padronizadas pelo judaísmo rabínico e mais próximas a um tipo de tradição mais comum a um judaísmo primitivo.

Após a análise das principais versões antigas da $\mathrm{BH}$, é necessário analisar a perícope de Is 52.13-53.12 dentro das tradições interpretativas judaicas e cristãs, para, posteriormente, entender como essas tradições interpretativas influenciaram determinadas traduções modernas, o que será feito no próximo tópico. 


\section{7. $\mathrm{O}$ texto de Is 52.13-53.12 e a tradição interpretativa nas fontes judaico-cristãs antigas}

Antes de expormos o texto e suas tradições interpretativas, é importante entendermos as abordagens da passagem dentro das perspectivas e interesses diferenciados, de um lado o interesse patrístico cristão em analisar a passagem na mesma ótica dos textos do Novo Testamento, do outro lado, a perspectiva e interesse rabínico, mais focado numa abordagem homilética da passagem do que expositiva, como comenta Rembaum:

O tratamento escasso de Isaías 53 nas fontes rabínicas é impressionante quando comparado com o interesse patrístico no capítulo e aos comentários extensivos da passagem encontrados nos trabalhos exegéticos do judaísmo medieval europeu. (...) o fator principal dessa diferença é o simples fato de que os comentadores da Idade Média geralmente escreveram comentários abrangentes e sistemáticos da Bíblia inteira ou livros e seções completas. Assim, um comentário no livro de Isaías deveria automaticamente incluir um tratamento do capítulo 53. O trabalho midráshico não jurídico do período rabínico, foi primariamente orientado através de propósitos homiléticos, não foram focados como os trabalhos medievais, e foram pouco sistemáticos. A única interpretação completa da passagem do Servo a aparecer na era talmúdica é a tradução aramaica do Pseudo-Jônatan. Aqui, a completude é uma função do gênero literário. A maioria das antigas fontes judaicas tratam segmentos selecionados de Isaías 53 e não refletem interesse em procurar um conceito unificado da passagem como um todo. (REMBAUM, 1982, p. 290291)

Abaixo, colocaremos o texto de nossa pesquisa, a tradução e como cada versículo ou conjunto de versículos foi interpretado nas fontes judaico-cristãs antigas. ${ }^{217}$ Primeiramente, contudo, veremos alguns intérpretes, tanto judeus como cristãos que fizeram uma análise da perícope inteira, para, posteriormente, ver as interpretações de verso a verso.

Nachmânides (רמב"ן), em seu Hinêy Yaskyl 'Avdy (הנה ישכיל עבדי), eis que meu servo procederá com prudência ${ }^{219}$, aplica a passagem inteira de Is 52.13-53.12 a Israel como um todo הנכון בפרשה הזאת שהיא על ישראל כלו A correta interpretação desta

217 Dentro das possibilidades de acesso às fontes em suas respectivas línguas de origem, citaremos o texto fonte e a tradução, contudo, devido às dificuldades de acesso a determinados textos fonte, faremos a tradução a partir de citações de segunda mão. As citações dos textos fontes se fará também de acordo com os expositores mais significativos dentro das duas tradições, já que ambas as tradições envolvem uma quantidade de textos que ultrapassaria o escopo desse trabalho.

218 Ramban (רמב"ן) é o acrônimo de Rav Mosheh ben Nachmân (רב משה בן נחמן), Rabino Moisés

filho de Nachman, conhecido também por Nachmânides.

219 Expressão retirada de Is 52.13, que se tornou o título do comentário da passagem feita pelo Ramban. 
parashah é sobre Israel como um todo) e depois segue aplicando ao texto uma interpretação אבל על דעת המדרש המיחס אותה על משיח :messiânica, utilizando a seguinte expressão ('aval 'al dê'at hamidraš hameyuhạas 'ôtâh mašîhạ), mas na opinião do Midrash [a passagem] é atribuída ao Messias. ${ }^{220}$ Outra interpretação da perícope como um todo atribuída ao Messias nos é informado por Bock e Glaser (2012, p. 63):

Notável, também, é o comentário muito citado do Rabino Moshe Alshech, escrito no século dezesseis, que diz 'nossos rabinos, em uma voz, aceitam e afirmam a opinião de que o profeta está falando a respeito do Messias, e nós devemos também aceitar a mesma visão'.

Orígenes em Contra Celsum 1.55 diz de uma disputa com certo judeu sobre a passagem e afirma que o judeu aplicava a passagem ao povo de Israel como um todo. (BOCK e GLASER, 2012, p. 63).

Justino, Mártir, também conhecido como Justino de Roma, no Diálogo com Trifão, descreve Trifão concordando que o Cristo (Messias) ${ }^{221}$ deveria sofrer:

Trifão me respondeu:

- Que tudo isso seja como dizes. Concedo também que esteja profetizado que Cristo devia sofrer e que é chamado pedra. Concedo também que, depois de sua primeira vinda, na qual estava anunciado que deveria sofrer, ele virá glorioso e como juiz de todos os homens e que, por fim, deveria ser rei e sacerdote eterno. Demonstra-nos agora que tudo isso estava profetizado exatamente a respeito desse Jesus. (Diálogo com Trifão 36.1)

Trifão insistiu:

- dá-nos agora a razão de que esse que dizes ter sido crucificado e ter subido ao céu é o Cristo de Deus. De fato, que o Cristo é anunciado nas Escrituras como sofredor, que virá novamente com glória para receber o reino eterno de todas as nações e que todo o reino lhe será submetido, está suficiente demonstrado pelas Escrituras que citaste. Contudo, que ele seja Jesus, isso terás agora que nos demonstrar. (Diálogo com Trifão 39.7$)^{222}$

Quanto a um messias sofredor, nas fontes judaicas, temos a citação da Pesyqta' Rabbaty de Rav Kahana' (פסיקתא רבתי דרב כהנא), texto midráshico do séc. VII d.C. ou anterior, o texto que se refere ao messias sofredor é o seguinte (DALY, 2007, p. 14):

Os pais do mundo [Abraão, Isaque e Jacó] ressuscitarão no mês de Nisã e dirão a

\footnotetext{
220 Ver texto e tradução no Apêndice B.

221 Nota-se em todo o diálogo que o termo grego Christos (Xpı otós) é entendido no mesmo conceito do que o termo hebraico Mašîạ (משיח) e não como um sobrenome de Jesus.

222 Passagens específicas serão citadas na análise dos respectivos versículos da perícope.
} 
ele: "Efraim, nosso verdadeiro Messias! Apesar de sermos seus pais, tu és maior do que nós, por tu teres sofrido por causa dos pecados de nossos filhos, e cruéis punições vieram sobre ti as quais não vieram antes, nem nas gerações seguintes, e tu foste exposto ao ridículo e em desprezo pelas nações do mundo por causa de Israel, e tu te assentaste em trevas e escuridão e teus olhos não viram a luz, sua pele fenda em teus ossos, seu corpo secou-se como madeira, e seus olhos se escureceram por causa do jejum, e sua força se tornou como caco. Tudo isso por causa do pecado de nossos filhos! Tu queres que os filhos venham a regozijar-se na alegria que o Santíssimo, bendito seja ele, atribuiu a Israel, ou frequentemente, por causa do grande sofrimento que tem vindo sobre ti, por causa da dívida deles, e por eles terem te aprisionado na prisão, [seja por isso] que a sua mente não está reconciliada com eles?"

E o Messias responde-lhes: "Pais do mundo. Tudo que eu fiz, fiz somente por causa de vossos filhos, e em vossa honra e em honra de vossos filhos, então, que eles possam se regozijar na alegria, que o Santíssimo, bendito seja o seu nome, tem atribuído a Israel."

Como já visto anteriormente, os targumim também interpretam a passagem de forma messiânica, demonstrando que essa tradição interpretativa já fazia parte de uma tradição comum às várias formas de judaísmo antigo.

Dentre os pais da Igreja que citam abundantemente a passagem e a interpreta relacionando-a com os sofrimentos de Jesus, temos Tertuliano (c. 160-220 d.C.) ${ }^{223}$

\section{Anti-Marcião, Capítulo VII, p. 326}

Afirmamos que, como há duas condições demonstradas pelos profetas que se referem a Cristo, assim também estes prefiguram o mesmo número de adventos, um, e que é o primeiro, foi para a humildade, quando Ele teve que ser levado como a ovelha para ser morto como vítima, e ser como um cordeiro mudo diante do tosquiador, não abrir a boca, e não é razoável considerar. (Is 53.7) Pois, diz (o profeta), anunciamos a respeito dele: "Ele é como um renovo, como raiz de uma terra sedenta; Ele não tem forma nem formosura, e vimos a Ele, e Ele era sem beleza: Sua forma foi desfigurada, $(53.2,3)$ desfigurado mais do que os filhos dos homens, um homem ferido com dores, e sabendo como suportar nossa fraqueza; (Is 53.3, 4)

Ele é mesmo um homem, diz Jeremias, e quem o reconheceu. Por isso, pergunta Isaías ", que contará a sua geração? (Is 53.8)

\footnotetext{
223

Extraído da tradução para o inglês de Roberts (1885-1896, Anti-Marcião, p. 326-420), os versículos relacionados à perícope foram inseridos no texto em negrito por nós. Devido às citações serem interpretadas fora de ordem, não colocamos na análise verso a verso, mas em linha corrida, conforme a abordagem de Tertuliano a respeito da passagem.
} 


\section{Anti-Marcião, Capítulo XVII, p. 335-336}

Vamos comparar com as Escrituras o resto de sua dispensação. Seja lá o que pobre corpo desprezado possa ser, porque era um objeto de toque e observação, será o meu Cristo, seja Ele inglório, seja Ele ignóbil, seja Ele desonrado, pois tal foi anunciado que ele deveria ser, tanto na condição corporal quanto no aspecto. Isaías vem à nossa ajuda novamente: "Nós anunciamos (Seu caminho) diante dele", diz ele: "Ele é como um servo, como raiz de uma terra seca; Ele não tem forma nem formosura; vimos, e Ele não tinha nem forma nem beleza, mas sua forma era desprezada, desfigurado mais do que todos os homens (Is 52.14; 53.2). Da mesma forma, o Pai, ao Filho se dirigiu um pouco antes:" Na medida em que muitos serão espantados de ti, assim será também a Tua beleza sem a glória dos homens..(Is 5214) Porque, apesar de, nas palavras de Davi, Ele ser mais justo do que os filhos dos homens", no entanto, é nesse estado figurativo da graça espiritual, quando Ele está cingido com a espada do Espírito, que é, na verdade, sua forma e beleza e glória. De acordo com o mesmo profeta, porém, ele está em condição corporal "um grande verme, e não homem, opróbrio dos homens e uma pária do povo."

Agora eu, propositadamente, exijo de ti, se tu conceder a ele o destino de toda essa humilhação e sofrimento, e tranquilidade, de que Ele é o Cristo de Isaías, um homem de dores, e experimentado no sofrimento, que foi levado como uma ovelha ao matadouro, e que, como um cordeiro diante do tosquiador, não abriu a sua boca (Is 53.3, 7), alguém que não luta nem chora, nem era a sua voz ouvida na rua, que não quebrou a cana ferida, ou seja, a fé despedaçada dos judeus, nem apagará o pavio que fumega, isto é, o ardor recém-aceso dos gentios. Ele não pode ser outro que o homem que foi predito. É certo que sua conduta deve ser investigada de acordo com a regra da Escritura, a menos que seja identificável como, se eu não me engano, pela dupla operação da pregação e do milagre. Mas, o tratamento de ambos os tópicos, eu devo providenciar posteriormente, para o capítulo onde eu determinei discutir o evangelho real de Marcião, a consideração de suas maravilhosas doutrinas e milagres, tendo em vista, no entanto, para o nosso propósito presente. Deixe-nos aqui, então, em termos gerais, completar o tema que tínhamos proposto acima, indicando, como passamos, como Cristo foi antes anunciado por Isaías como um pregador: "Por que há entre vós", diz ele, "que temeis ao Senhor, que obedeceis a voz de Seu Filho?" E da mesma forma como um curador: "Porque", diz ele, "Ele tirou as nossas enfermidades, e as nossas dores" (Is 53.4).

\section{Anti-Marcião, Capítulo XIX, p. 338}

No entanto, vou mostrar-lhe a morte, o sepultamento e a ressurreição de meu Cristo tudo indicado em uma única frase de Isaías, que diz: "Sua sepultura foi retirada do meio deles." Agora, não poderia ter havido nenhuma sepultura sem morte, e nenhuma remoção de sepultura, exceto pela ressurreição. Então, finalmente, ele acrescentou: ". Portanto, Ele deve ter muitos por sua herança, e repartirá ele o despojo de muitos, porquanto 
derramou a sua alma na morte" (Is 53.12) Pois não é aqui estabelecida a causa deste favor para Ele, mesmo que a recompensa era por Sua paixão da morte. Foi igualmente demonstrado que era para obter esta recompensa por sua morte, foi, certamente, para obtê-la depois de sua morte por meio da ressurreição.

\section{Anti-Marcião, Livro III, Capítulo XXIII, p. 341}

Bem, então, apesar de afirmar que é o Cristo do outro deus que foi levado para a cruz pelos poderes e autoridades do Criador, como se fosse por seres hostis, ainda que tenho a dizer, veja como é manifesto que Ele era defendido pelo Criador: havia sido dado a ele ambos "o ímpio para o Seu sepultamento", e aqueles que tinham veementemente afirmado que seu corpo tinha sido roubado ", e os ricos em sua morte," (Is 53.9) (...)

\section{Anti-Marcião, Livro IV, Capítulo VIII, p. 354}

Ele era, portanto, o próprio Cristo de Isaías, o curador da nossas enfermidades. (Is 53.4) "Certamente", disse ele, "ele tomou sobre si nossas dores e as nossas enfermidades." Agora, os gregos estão acostumados a usar para 'levar' uma palavra que também significa 'tirar'.

\section{Anti-Marcião, Livro IV, Capítulo X, p. 357-358}

"Levanta-te, toma o teu leito", e coragem também moral para não ter medo de quem deveria dizer: "Quem pode perdoar pecados senão Deus?" Então você tem aqui não só o cumprimento da profecia que prometia um determinado tipo de cura, mas também dos sintomas que se seguiram à cura. Da mesma maneira, você também deve reconhecer Cristo no mesmo profeta como o perdoador de pecados. "Porque", diz ele, ". Ele dispensará a muitos do pagamento de seus pecados, e ele tirará os nossos pecados" (Is 53.12).

\section{Anti-Marcião, Livro IV, Capítulo XXI, p. 364}

Mas, como para o nosso Cristo, Ele não poderia fazer de outra forma a não ser fazer tal declaração; "feito" pelo Pai "um pouco menor que os anjos," ", um verme e não homem, opróbrio dos homens e desprezado das pessoas "; vendo que era Sua vontade que" pelas suas pisaduras nós seríamos curados" (Is 53.5), que por sua humilhação seria estabelecida a nossa salvação.

Anti-Marcião, Livro IV, Capítulo XL，p. 418

(...) Ele teve que ser "levado como um cordeiro ao matadouro;? E porque, 
como uma ovelha que diante de seus tosquiadores fica mudo, de modo que ele não abriu a sua boca" (Is 53.7).

\section{Anti-Marcião, Livro IV, Capítulo XLII, p. 420}

Herodes "alegrou-se" quando viu Jesus, mas ele não ouviu uma palavra dele pois, "como um cordeiro diante do tosquiador é mudo, ele não abriu a sua boca", (Is 53.7) (...)

Vejamos outras tradições interpretativas da perícope verso a verso:

\subsection{3}

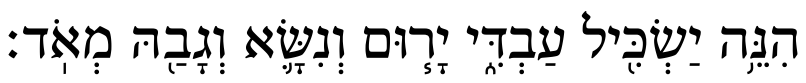

Eis que meu servo agirá com prudência, será exaltado, engrandecido e muito elevado.

De acordo com Bock e Glaser (2012, p. 62-63), "o Midrash Tanchuma aplica ambos, 52.13, falando da Exaltação do Servo, e 53.3, 'um homem de dores e conhecedor de efermidades', ao Messias".

Bock e Glaser (2012, p. 62-63) citam, também, o:

Yalkut Shimoni (uma compilação do século XIII de antigos escritos midráxicos) aplica 52.13 ao Messias, declarando que o Messias, chamado a grande montanha, de acordo com a interpretação do Yalkut de Zacarias 4.7, é 'maior do que os patriarcas... maior do que Abraão... elevado sobre Moisés... e mais elevado do que o ministério dos anjos' (2:571; veja também 2:621).

$\operatorname{Rashi}^{224}$

\section{"הנה ישכיל עבדי" - הגה באחרית טימים ילניח עברי יעקב לדיקים שבו}

Eis que agirá com prudência - Eis que no fim dos dias triunfará meu servo, Jacó, os justos que estão entre ele

224 Os textos fontes de Rashi são tirados de Miqra'ot Gedolot em Isaías (מקראות גדולות - ישעיה) disponível em: http://hebrewbooks.org/14257 acesso em: 17 mar. 2013. Utilizamos como auxílio para a tradução, a versão em inglês disponível em:

$<$ http://www.chabad.org/library/bible_cdo/showrashi/false/aid/15983/jewish/Chapter-52.htm>, e em: $<$ http://www.chabad.org/library/bible_cdo/showrashi/false/aid/15984/jewish/Chapter-53.htm > acesso em: 18 mar. 2013 e também a tradução feita por Driver e Neubauer (1877, Vol II, p. 37-40), com adaptações feitas quando consideradas necessárias. 
52.14

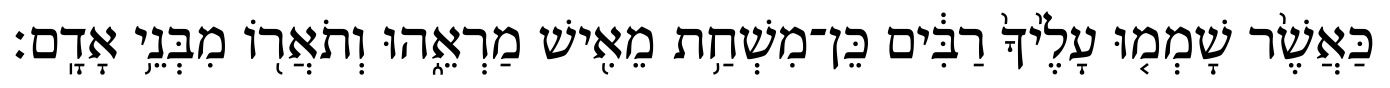

Como ficarão espantados sobre ti muitos, a sua aparência será mais desfigurada do que a de um homem, e a sua aparência mais do que a dos seres humanos.

Rashi

"כאשר שממו" - כאשר תמהו עליהם עמים רבים בכאותם שפלותם ואמכו

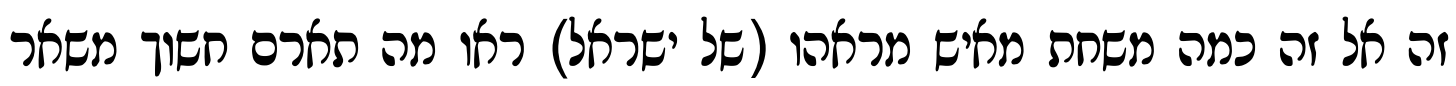

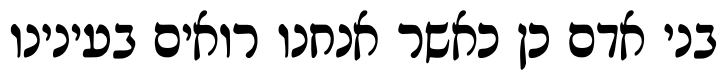

Como ficarão espantados - Como se surpeenderam sobre eles muitos povos ao ver o estado deplorável deles e dirão um ao outro: quão destruidora aparência humana é a dele (de Israel), verão o aspecto dele como trevas, mais do que dos outros filhos dos homens, assim como nós vemos em nossos olhos.

\subsection{5}

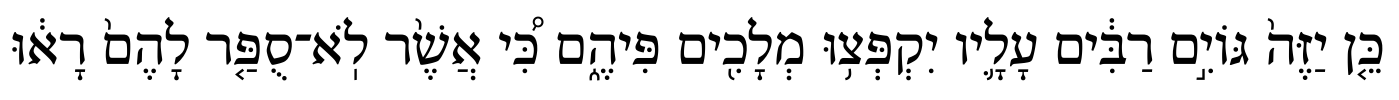

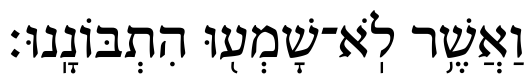

Por isso, borrifará muitas nações sobre ele; reis fecharão as suas bocas, pois o que não lhes foi contado viram, e o que não ouviram, compreenderão.

Maimônides (רמב"ם Rambam, rabino Moshe ben Maimon) em sua Epístola ao Iêmen ${ }^{225}$ diz o seguinte sobre este versículo:

Isaías descreve a subserviência dos reis ao Messias no seguinte versículo: "Reis fecharão suas bocas por causa dele; porque eles verão aquilo que não lhes foi contado, e observarão aquilo que não lhes foi dito" (Isaías 52.15). Executará a quem ele quiser pela palavra de sua boca. (MAIMÔNIDES, 1996, p. 52)

Rashi

225 Estamos usando a versão em português feita por Alice Frank e publicada pela editora Maayanot supra
citada. 


\section{"כן יזה גוים רבים" - כן עתס גם טוא תגבר ידו וידה את קכנות העכו"ס

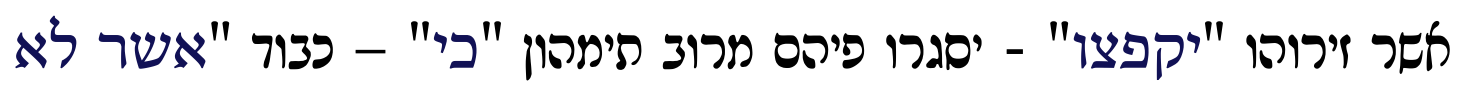

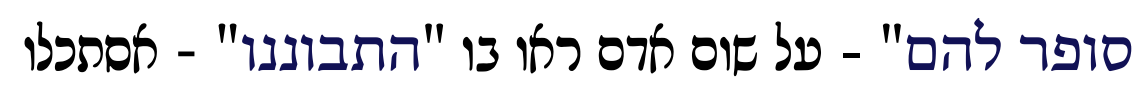

Assim, dispersou muitas nações - assim, agora, também ele levantará sua mão poderosa e os chifres dos pagãos que o dispersaram fecharão - fecharão as bocas deles de grande espanto, pois a glória que não lhes foi contada - a respeito do que ninguém viu nele compreenderão - $\mathrm{o}$ aspecto dele.

\section{1}

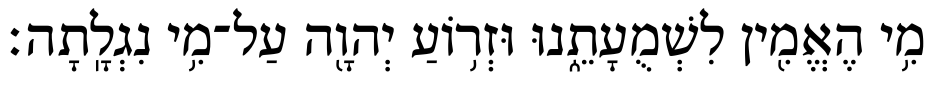

Quem deu crédito ao nosso anúncio, e à semente de YHWH a quem foi revelada?

Rashi

\section{"מי האמין לשמועתינו" - כן יאמכו העכו"ס איש לכעהו אילו הינו

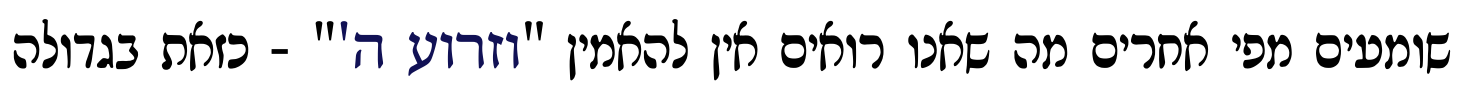

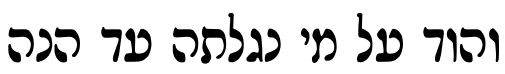

Quem deu crédito ao nosso anúncio - assim disseram os pagãos uns aos outros que havíamos ouvido de outros lábios o que nós temos visto sem acreditar e a semente de YHWH - tal grandeza e glória a quem foi revelado até agora?

53.2

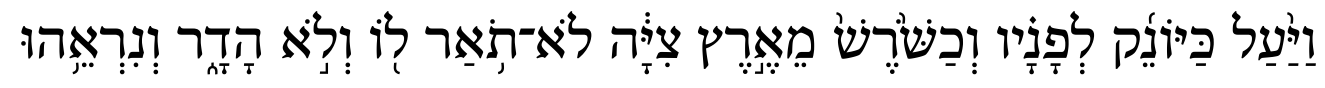

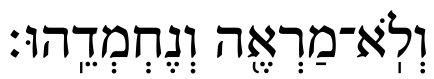

Pois foi subindo como um rebento diante dele, como a raiz de uma terra seca, ele não tinha aparência e nem esplendor; olhando nós para ele não havia aparência para que pudéssemos nos agradar dele.

Maimônides em sua Carta ao Yêmen (Iggeret Teman) relaciona essa passagem ao Messias: 
Assim, também, Isaías disse que ele vai chegar sem ninguém saber sobre seu pai, sua mãe ou família: "Porque surgiu como um rebento, como uma raiz de uma terra seca” (Isaías 53.2) (MAIMÔNIDES, 1996, p. 51-52)

Rashi

"ויעל כיונק לפניו" - העם הזה לפני בא לו הגדולה הזאת עם שפל היה

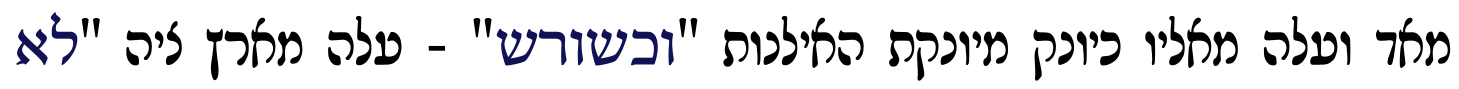

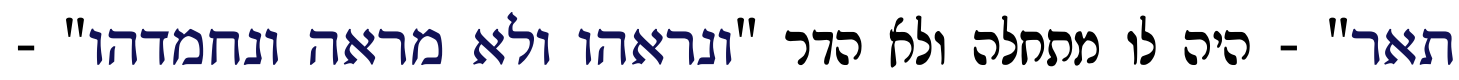

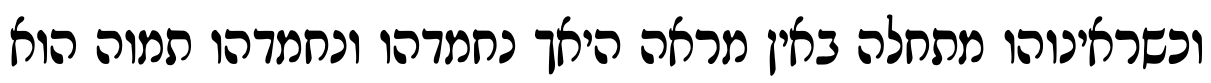

Pois foi subindo como um rebento diante dele - Este povo, antes desta grandeza era muito humilde e ele subiu para eles como rebento de mudas de árvores - e como raiz - ele subiu de uma terra seca - não tinha aparência - ele não tinha no início nenhuma aparência olhando nós para ele não havia aparência para que pudéssemos nos agradar dele. - E olhando nós para ele no princípio, sem aparência, como o desejaríamos? E o desejarmos era estranho.

53.3

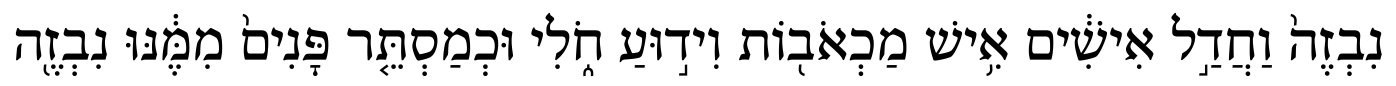

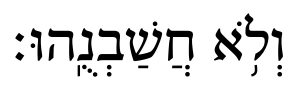

Ele foi desprezado e rejeitado dos homens, homem de dores e que conhece o sofrimento; $e$ como alguém de quem se esconde o rosto, foi desprezado por nós e nós não o consideramos.

De acordo com Bock e Glaser (2012, p. 62-63), “o Midrash Tanchuma aplica ambos, 52.13, falando da Exaltação do Servo, e 53.3, 'um homem de dores e conhecedor de enfermidades', ao Messias".

Rashi

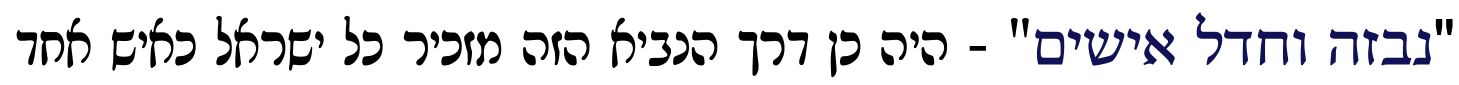

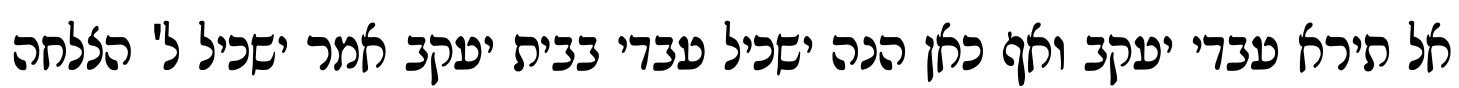




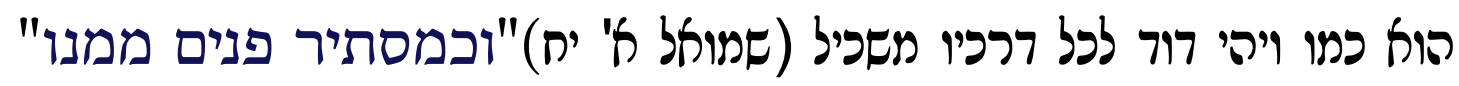

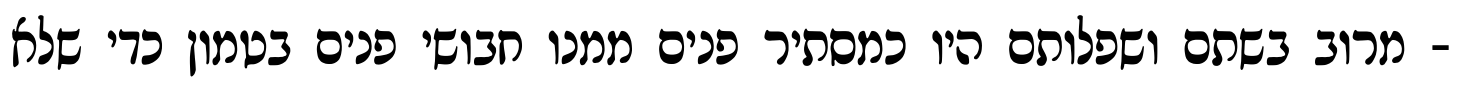 נכאה אותם כאדם מנוגט שמסתיר פניו וירא מכביט}

Ele foi desprezado e rejeitado dos homens - era assim o caminho deste profeta, lembra Israel como um único homem para ver o meu servo Jacó e, até aqui, eis que agirá com prudência meu servo, na casa de Jacó, diz yaskyl, pois é uma expressão que significa prosperidade, pois ele será como Davi, que em todos os seus caminhos foi bem sucedido (maskyl) (I Samuel 18) - e como alguém de quem se esconde o rosto - do grande vexame e humilhação, eles eram como alguém de quem se esconde o rosto de nós, rostos vendados para que não seja visto, como um homem atormentado que esconde seu rosto temendo que olhem para ele.

\section{4}

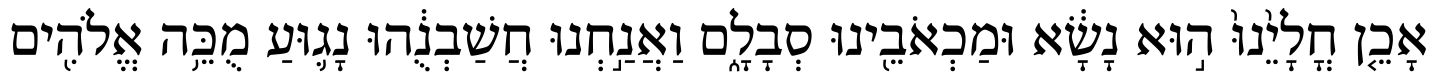

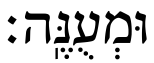

Verdadeiramente, ele carregou as nossas doenças, as nossas dores ele as levou, e nós o considerávamos como um ferido, um afligido por Deus, um humilhado.

Talmude Babilônico: Sanhedrin $98 \mathrm{~b}^{226}$

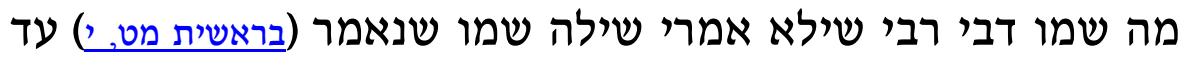

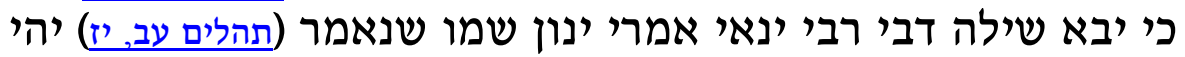

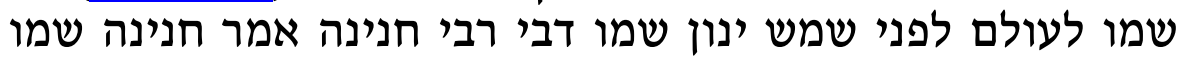

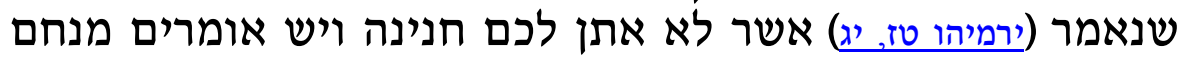

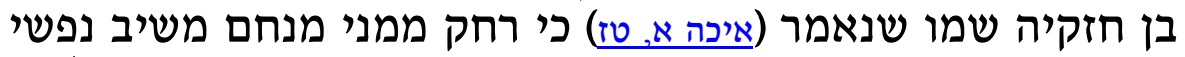

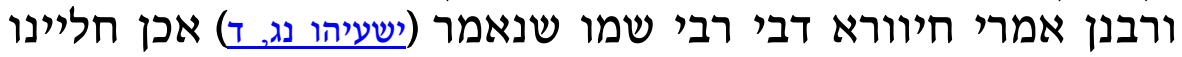
הוא נשא ומכאובינו סבלם ואנחנו חמורבי חשבנוהו נגוע מוכה אלהים חלינו

ומעונה

Qual o nome dele [do Messias]? A escolas de Rabi Shila’ disse: seu nome é Shiloh, pois está escrito: “até que venha Shiloh" (Gn 49.10). A escolas de Rabi Yanai disse: Seu nome é Ynon, pois está escrito: “permaneça seu nome eternamente” (S1 72.17),

226

Texto hebraico disponível em:

$<$ http://he.wikisource.org/wiki/\%D7\%A1\%D7\%A0\%D7\%94\%D7\%93\%D7\%A8\%D7

$\% 99 \% \mathrm{D} 7 \% 9 \mathrm{~F} \% \mathrm{D} 7 \% \mathrm{~A} 6 \% \mathrm{D} 7 \% 97 \% \mathrm{D} 7 \% 91>$ acesso em: 15.03 .13 , obs.: o endereço do link parece estranho mais é esse mesmo, essa numeração se dá pelo fato do texto do link estar em caracteres hebraicos no padrão Unicode. 
assim como o sol permanence, seu nome permanecerá Ynon. A escola de Rabi Hanina afirmou: seu nome é Hanina, como está escrito, "onde não darei para ti, Hanina (Jr 16.13). Outros dizem: seu nome é Menaken, pois está escrito "porque está longe de mim um Menaken [consolador] que pudesse renovar o meu ânimo" (Lm 1.16). Os rabinos disseram: Seu nome é "o erudito leproso", conforme está escrito: "verdadeiramente ele tomou sobre si as nossas enfermidades, e carregou com as nossas dores; e nós o reputávamos por aflito, ferido de Deus e oprimido" (Is 53.4).

Rashi

\section{"אכן חליינו הוא נשא" - אכן ל" אבל בכל מקום אבל עתס אנו כואים שלא

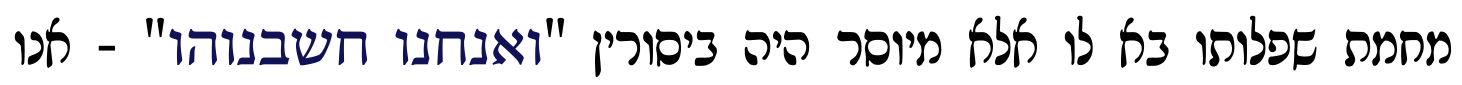

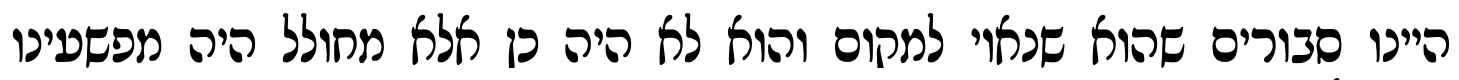 ומדוכא מטונותיעו שכוס}

Verdadeiramente, ele carregou as nossas doenças - âken significa 'mas' em todos lugares, mas agora vemos que não era por causa da humilhação que ele veio, mas porque ele era atormentado com dores - e nós o considerávamos - nós estávamos pensando que ele era odiado por Deus ${ }^{227}$, e ele não era assim, mas era afligido por causa dos nossos pecados e ferido de nossas iniquidades.

\section{5}

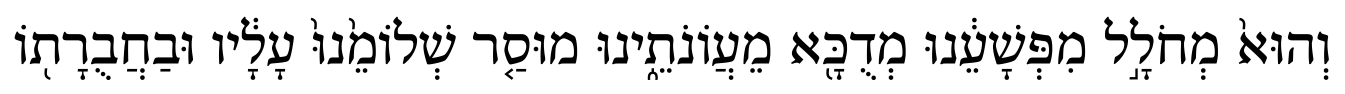

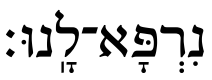

Mas ele foi perfurado pelas nossas transgressões, foi destroçado por causa das nossas maldades, o castigo de nossa paz estava sobre ele, e pelo ferimento dele houve cura para nós.

O Midrash de Ruth Rabah traz a seguinte interpretação para este texto:

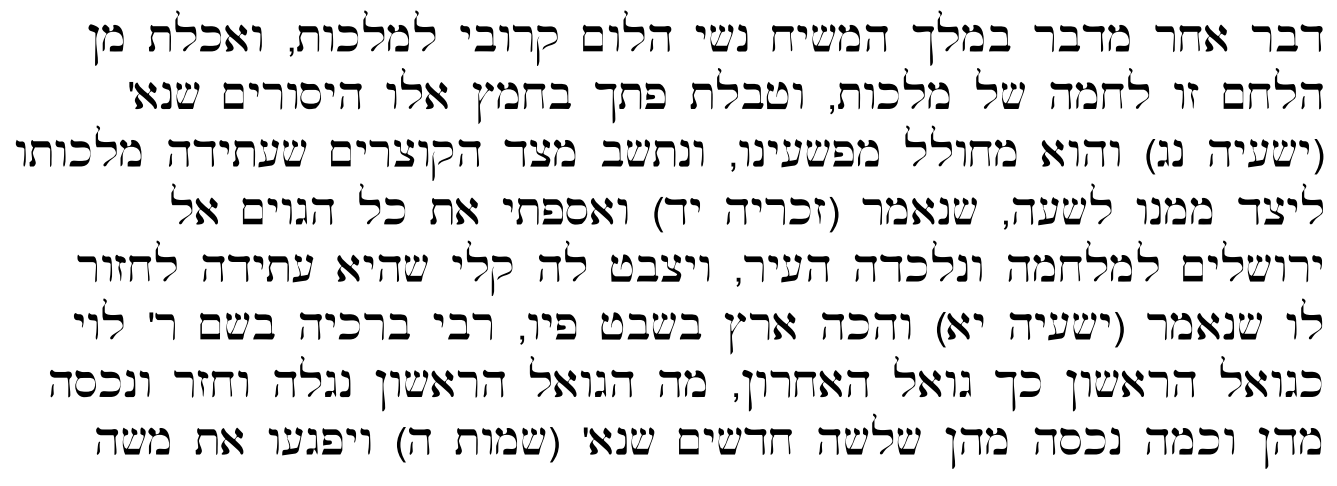




\section{ואת אהרן, אף גואל אחרון נגלה להם וחוזר ונכסה מהם}

A quinta interpretação (a abreviação ד־) faz referência ao Rei Messias. VENHA que está próximo o reino (קרובי למלכות). E COMA O PÃO refere-se ao pão do reino (לחמה של מללבות); למתות); E MERGULHAR SEU PEDAÇO DE PÃO NO VINAGRE refere-se ao seu sofrimento, como diz, Mas ele foi ferido por causa de nossas transgressões (Is LIII, 5). E ELA SENTOU AO LADO DOS SEGADORES, por ele será privado do seu reino (עתידה מלכותו ליצד ממנו) por um tempo, como diz, Pois eu ajuntarei todas as nações contra Jerusalém para batalha; e a cidade será tomada (Zc XIV, 2). E ELES (sic!) FEZ CHEGAR A ELA O TRIGO TOSTADO, significa que ele será restaurado ao seu reino, como diz, E ele ferirá a terra com a vara de sua boca (Is XI, 4). R. Berakiah diz em nome de R. Levi: $\underline{O}$ futuro Redentor será como o primeiro Redentor. Assim como o primeiro Redentor revelará a si mesmo, retornou e foi depois ocultado deles; e quanto tempo foi ocultado? Três meses, como diz, $E$ eles encontraram Moisés e Arão (Êx V, 20), Assim, o futuro Redentor será revelado a eles, e então será ocultado deles. ${ }^{228}$ :

Para explicar essa passagem, no capítulo 5 (SANTALA, 2002, p. 99-114), o autor discute a interpretação de Is 53 em várias fontes judaicas, tais como Talmud, Zohar, Orações Judaicas, bem como nas reflexões sobre o texto na Idade Média.

Bock e Glaser (2012, p. 62-63), no Yalqut Shimoni, "Isaías 53.5 é aplicado ao sofrimento do 'Rei Messias' (2:620)".

Rashi

\section{"מוסר שלומינו עליו" - באו עליו יסוכי השלום שהיה לנו שהוא היה מיוסר להיות שלום לכל העולם}

O castigo de nossa paz estava sobre ele - Vieram sobre ele os castigos da paz que era nossa, pois ele foi atormentado para haver paz para todo o mundo.

53.6

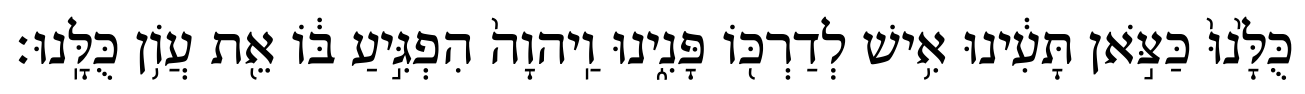

Todos nós andávamos errantes como ovelhas, cada um se voltava para seu próprio caminho, mas YHWH fez chegar a ele a maldade de todos nós.

228 ה. ה.ררש רות רבה 2 , p. 16A, tradução adaptada por nós com base em SANTALA, 2002, p. 99-114. 
Na epístola de Barnabé 5.1-3 também encontramos uma interpretação cristã dos versos 5 e 6 :

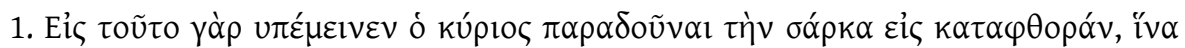

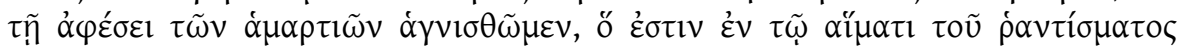

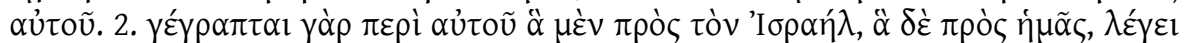

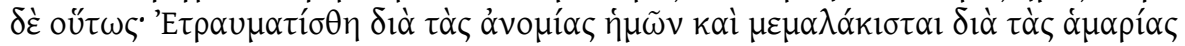

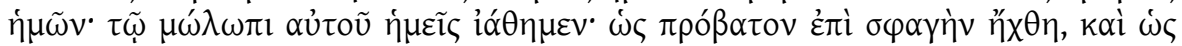

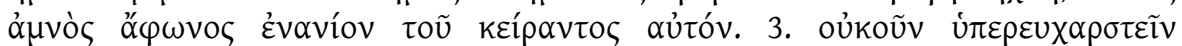

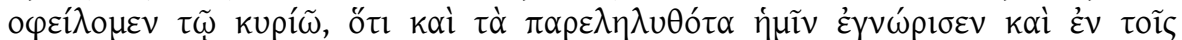

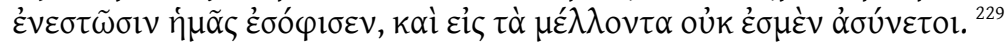

Pois isso suportou o senhor, entregou a carne para destruição, a fim de que na remissão dos pecados fossemos santificados, o qual está no sangue da sua aspersão. 2. Pois está escrito a respeito dele o que é tanto para Israel quanto para nós, pois diz assim: ele foi ferido pelas nossas iniquidades foi enfraquecido pelos nossos pecados, no ferimento dele fomos sarados, como ovelha que é conduzida para o abate, como cordeiro que fica mudo diante do seu tosquiador. 3. Por isso, devemos ser grandemente agradecidos ao senhor, porque ele nos tem dado a conhecer tanto as coisas passadas, quanto nos tem dado sabedoria para conhecer as coisas presentes, e também não nos deixou sem entender as coisas que estão por vir. ${ }^{230}$

Não está claro aqui se o que o autor está querendo dizer é que os efeitos da morte de Jesus são tanto para Israel quanto para a Igreja ou se ele está admitindo que o texto de Isaías 53.5, 6 tem tanto uma interpretação coletiva, referindo-se a Israel, quanto uma interpretação individual, referindo-se aos sofrimentos de Jesus por todos

Rashi

\section{"כולנו כצאן תעינו" - עתס נגלה כי כל העכו"ם תעו "הפגיע בו" -

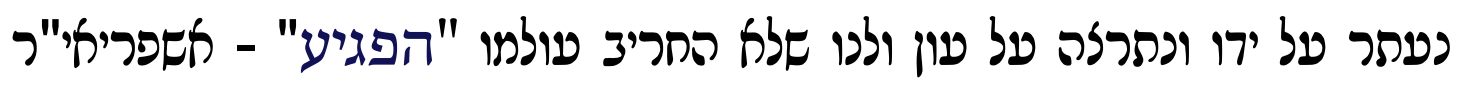

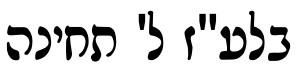

Todos nós andávamos errantes como ovelhas - agora foi revelado que todos os pagãos tinham errado - fez chegar a ele - foi aceito por meio dele e foi acolhida a iniquidade de todos nós, por isso que não fez destruir o mundo - fez chegar - asprier (francês) ${ }^{231}$ em língua

\footnotetext{
229 Texto grego extraído de Lake (2013, p. 73).

230

Tradução nossa.
Troxto grego extraido de Lake (2013, p. 73)
}

231 Driver e Neubauer (1877, p. 38) traduzem: asprier, in French, $<$ http://www.chabad.org/library/bible_cdo/showrashi/false/aid/15984/jewish/Chapter-53.htm> acesso em: 25.03.13, traduz: espriad in O.F. (Old French), nenhuma das duas entradas consegui encontrar no francês arcaico, a busca em: <http://www.lexilogos.com/etymologie.htm> acesso em: 25 mar. 2013 não retornou nenhuma entrada exata em nenhum dos muitos léxicos do francês arcaico neste site. A transliteração do texto de Rashi sem vocalização daria 'spryhy" $r$, a proximidade com o frânces aspirer = aspirar, no sentido de suspiro é uma possibilidade. 
estrangeira uma expressão que significa súplica.

53.7

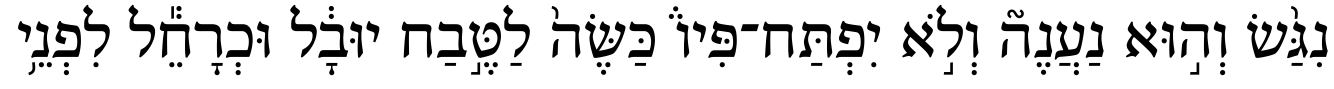

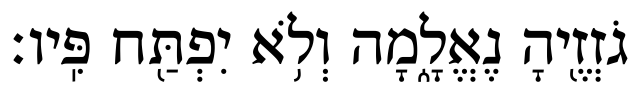

Ele foi oprimido e humilhado, mas não abriu a sua boca, como um cordeiro que é conduzido para o sacrificio, como ovelha que se cala diante do que a tosqueia, ele não abriu a sua boca.

Trifão disse:

- Instruir-nos sobre isso através das Escrituras, para que também nós nos convençamos. Com efeito, sabemos que ele haveria de sofrer e ser conduzido como ovelha ao matadouro. O que tens que demonstrar é que ele também deveria ser crucificado e morrer de morte tão desonrosa e amaldiçoada pela própria lei. Nós, de fato, não podemos sequer imaginar isso. (Diálogo com Trifão 90.1)

Rashi

\section{"נגש והוא נענה" - כגש הגה בנוגשים ודוחקים "והוא נענה" - באוגאת

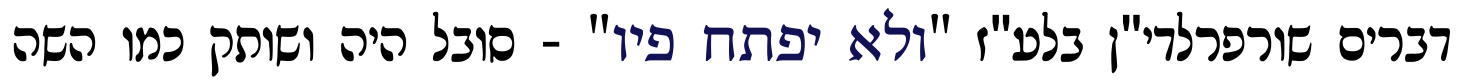

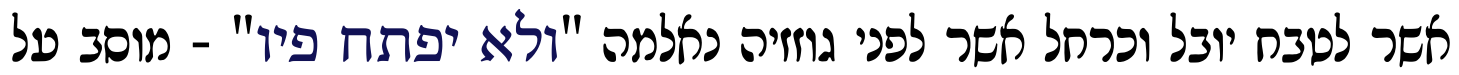 שה לטבח יובל}

Ele foi oprimido e humilhado - eis que ele foi oprimido por feitores e opressores - $e$ humilhado - causando sofrimento por falar muito, sourparler ${ }^{232}$, em língua estrangeira - mas não abriu a sua boca - ele estava sofrendo e em silêncio, como o cordeiro que é conduzido ao matadouro e como ovelha que diante dos seus tosquiadores está muda - mas não abriu a sua boca - se refere ao cordeiro que é conduzido ao matadouro.

53.8

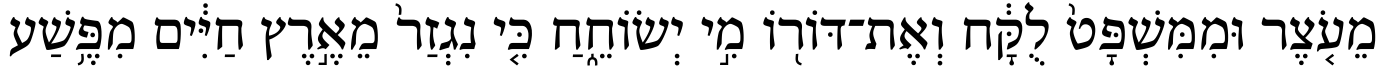

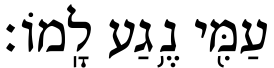

Da opressão e do juizo foi tomado, a sua geração, quem a considerou? Pois foi cortado da

232 Driver e Neubauer (1877, p. 38) traduzem surparler, in French,

$<$ http://www.chabad.org/library/bible_cdo/showrashi/false/aid/15984/jewish/Chapter-53.htm> acesso em: 25.03.13, traduz: sorparlec in O.F. (Old French), a busca em:

$<$ http://micmap.org/dicfro/chercher/dictionnaire-godefroy/sourparler> acesso em: 25 mar. 2013, remete à palavra sourparler que significa falar muito, o que corresponde à expressão hebraica באונאת רברים (be'ônâ't devârîm), ver Sapir Hebrew-Hebrew [em hebraico] (2012), também Even-Shoshan (1979, p. 39). 
terra dos vivos, por causa do pecado do meu povo foi golpeado.

Rashi

"מעוצר וממשפט לוקח" - הגביא מבשכ ואומכ כי זאת יאמכו העכו"ם באחרית הימים כשיראו כשנלקח מן העולר שפיה עלוכ בידם וממשפט היסוכין

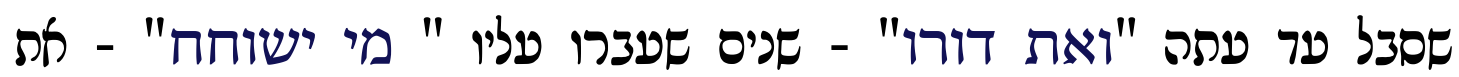

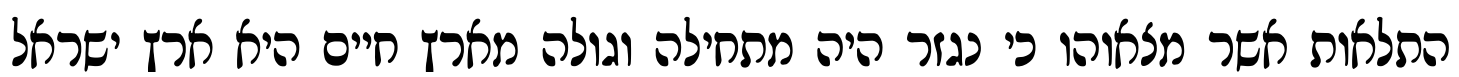

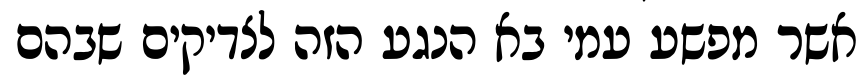

Da opressão e do juizo foi tomado - o profeta informa e diz que isto dirão os pagãos no fim dos dias, quando eles veem que ele foi tomado da prisão pelas mãos deles e do juízo dos tormentos que sofreu até agora - a sua geração - os anos que passaram sobre ele - quem a considerou? - primeiramente ele tinha sido cortado e exilado da terra dos viventes, esta é a terra de Israel, pois da transgressão do meu povo veio este ferimento aos justos que havia entre eles.

53.9

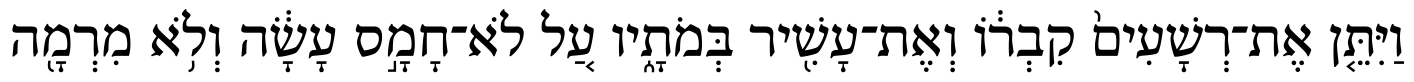

Deu-lhe a sua sepultura com os ímpios, mas com o rico na sua morte, pois violência não cometeu, e engano não havia em sua boca.

Rashi

"ויתן את רשעים קברו" - מסר את עלמו להקבר ככל אשר יגזכו עליו

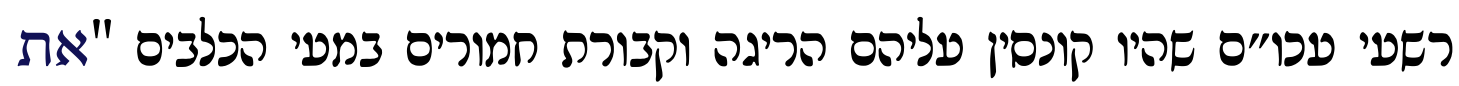

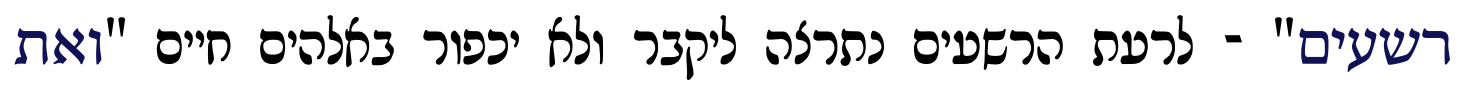

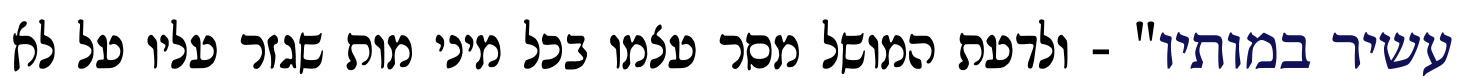

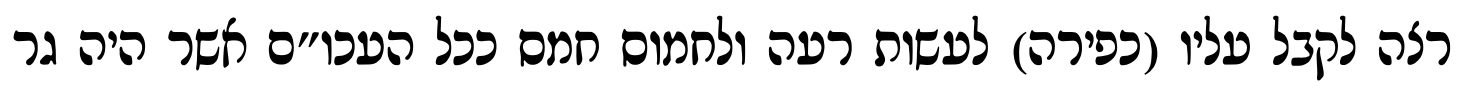

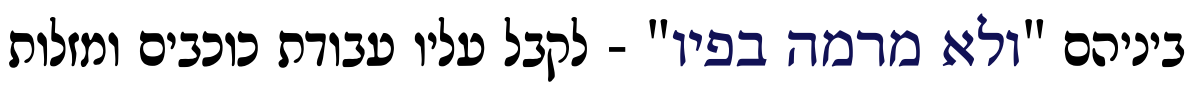


Deu-lhe a sua sepultura com os ímpios - deu a si mesmo para ser enterrado, conforme tudo que determinaram sobre ele, os ímpios, pagãos que eram penalizados para serem mortos como o sepultamento de asnos em intestinos de cães - com os ímpios - de acordo com a vontade dos ímpios, ele se acomodou a ser sepultado e para não contender com o Deus vivo - mas com o rico nas suas mortes - e para conhecer a lei, ele entregou a si mesmo em todo tipo de morte que foi determinada sobre ele, para não concordar em receber sobre ele (heresia), para fazer mal e pilhagem, saques, como os pagãos que viviam entre eles - e engano não havia em sua boca - para aceitar sobre ele adoração às estrelas e sinais.

Para Orígenes, esse texto demonstra a ausência de pecado em Jesus, como lemos:

(...) odiar a iniquidade remete ao que a Escritura disse de Cristo: "Não cometeu pecado e não se encontrou malícia na sua boca" (Is 53,9); e ainda: "foi tentado em todas as coisas, de modo semelhante a nós, mas sem pecado" ( $\mathrm{Hb} 4,15)$. (ORÍGENES, Tratado sobre os Princípios, p. 164)

53.10

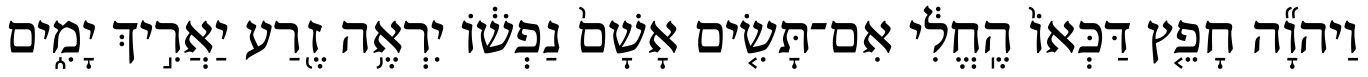

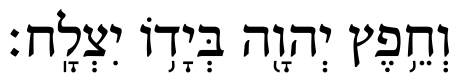

YHWH desejou destroçá-lo, fazendo-o enfermar, pois quando colocar por oferta de expiação a sua alma, ele verá a semente e os seus dias se prolongarão; E a vontade de YHWH em suas mãos triunfará.

Talmude Babilônico: Berakoth $5 \mathrm{a}^{233}$

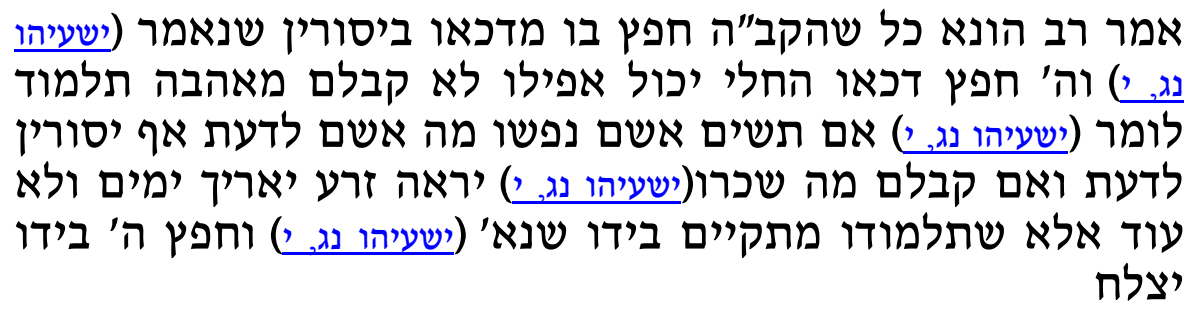

Disse Rav Huna' tudo o que, o Santíssimo, abençoado seja, desejou nele, [é que] suas dores [fossem] ferimentos, pois diz [Is 53.10] (e YHWH desejou destroçá-lo), mesmo não sendo recebidas por amor, o Talmud diz [Is 53.10] pois quando colocar por oferta de expiação a sua alma, que oferta para saber até dores conhecer e se forem recebidas qual a sua recompensa? [Is 53.10] ele verá a semente e os seus dias se prolongarão, e não até mais, mas que o seu ensino por meio dele perdurará. [Is 53.10] E a vontade de YHWH em suas mãos triunfará.

\footnotetext{
233 Texto hebraico disponível em:
}

<http://he.wikisource.org/wiki/\%D7\%91\%D7\%A8\%D7\%9B\%D7\%95\%D7\%AA_\%D7\%94_\%D7\%90> acesso em: 15 mar. 2013. 


\section{"וה' חפץ דכאו החלי" - הקב"ה חפץ לדכאו ולהחזיכו למועב לפיכך החלה

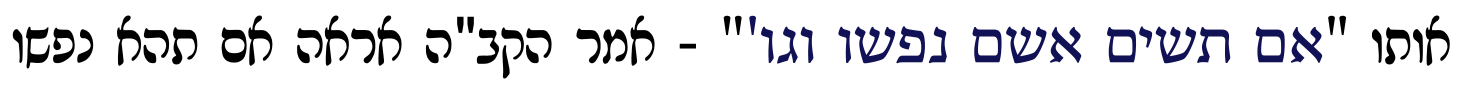

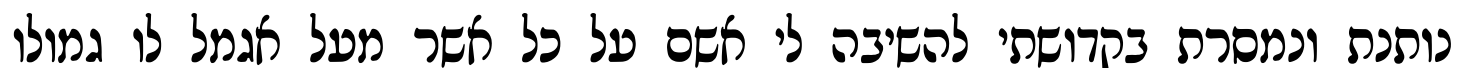

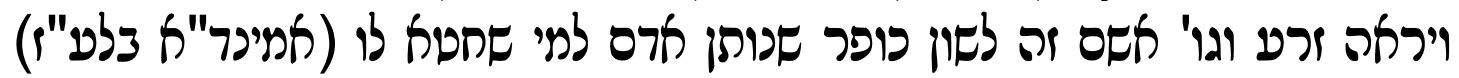

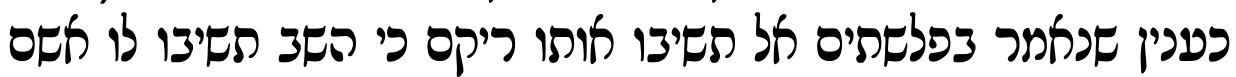

YHWH desejou destroçá-lo, fazendo-o enfermar - E o Santíssimo, Bendito Seja, quis feri-lo e fazê-lo mudar para melhor, por isso o fez enfermar - pois quando colocar por oferta de expiação a sua alma - Disse o Santíssimo, Bendito Seja, verei se será a sua alma dada e entregue a minha santidade para retornar para mim, como restituição sobre todo o que recompensarei a ele a sua recompensa, e a semente, ele verá, etc, esta palavra 'asham é uma expressão de resgate que se dá a um homem quando peca contra outro, amende em língua estrangeira, como na questão em que está dito sobre os filisteus para a enviarem não de mãos vazias, porém, sem falta enviarem a ele uma oferta de expiação.

\subsection{1}

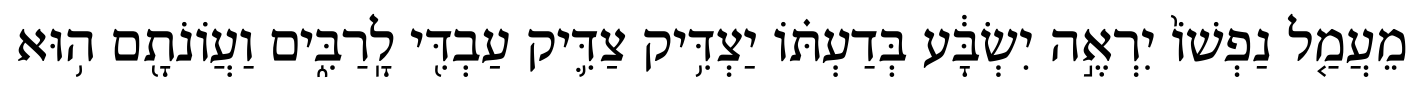
יִסְבּלּ:

Ele verá o trabalho da sua vida e estará satisfeito, com o seu conhecimento o meu servo, o justo, justificará a muitos, pois a maldade deles ele carregará.

Rashi

"מעמל נפשו" - טיה אוכל ושבט לא היה גוזל וחומס "בדעתו יצדיק

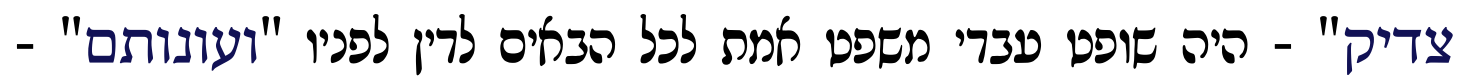

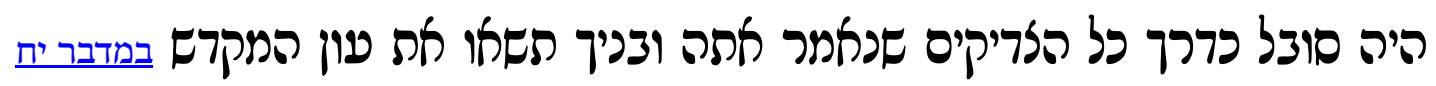

Ele verá o trabalho da sua vida - ele se alimentou e ficou satisfeito ele não roubou e saqueou - conhecimento, o justo, justificará - poderá julgar meu servo um juízo verdadeiro para todo o que vier para ser julgado por ele - a maldade deles - ele carregará o sofrimento, conforme o caminho de todo os justos, pois diz tu e teus filhos levarão a iniquidade do santuário (Nm 18.1).

53.12 


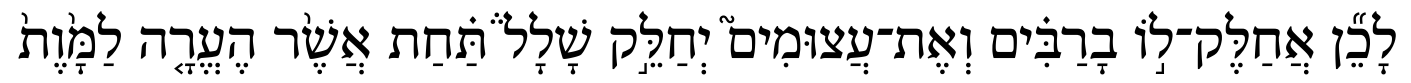

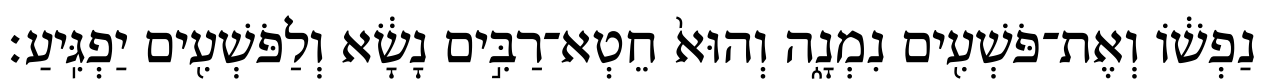

Por isso, eu repartirei com ele uma multidão, com os poderosos ele repartirá despojos, por ter entregado a sua alma na morte e ter sido contado com os transgressores. O pecado de muitos carregará e pelos transgressores intercederá.

Talmude Babilônico: Sotah 14

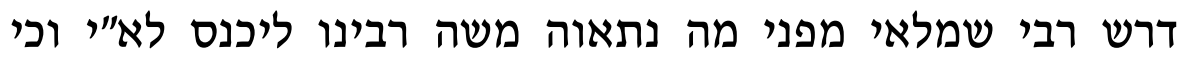

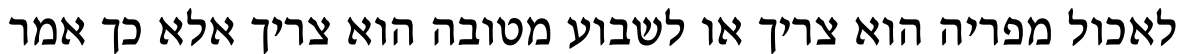

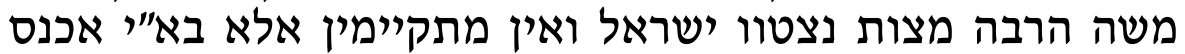

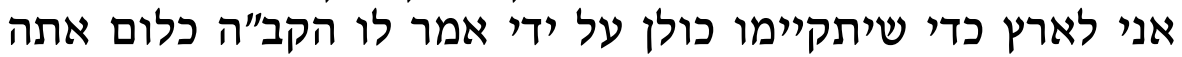

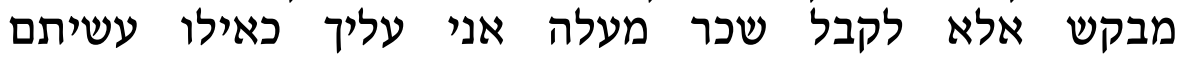

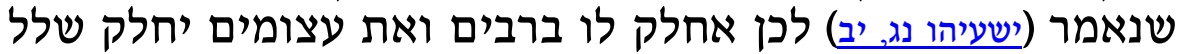
תחת אשר הערה למות נפשו ואת פושעיק ברים נמנה והוא חטא רבים יבים

נשא ולפושעים יפגיע

R. Simlai expôs: Por que Moisés nosso mestre anseia por entrar na terra de Israel? Será que ele quer comer de seus frutos ou certificar-se de sua bondade? Mas, assim falou Moisés, "muitos preceitos foram ordenados a Israel, que só podem ser cumpridos na terra de Israel. Gostaria de entrar na terra de modo que todos eles possam ser cumpridos por mim". O Santo, bendito seja Ele, disse-lhe: 'É só para receber a recompensa [por obedecer os mandamentos] que procuras? Eu atribuo isso a ti como se tu as tivessem realizado", como é dito: Por isso que eu dividirei com ele uma parte com os grandes, e ele dividirá os despojos com os fortes, porque ele derramou a sua alma na morte, e foi contado com os transgressores, ainda que ele carregou os pecados de muitos, e intercedeu pelos transgressores.

Rashi

\section{"לכן" - על עשותו זאת אחלק bا נחלה וגוכל בכבים עם האבות הכאשונים}

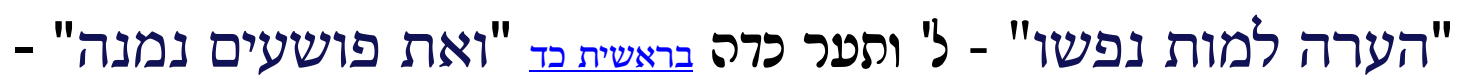

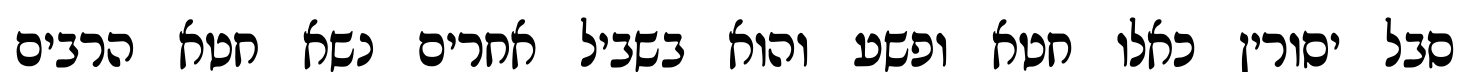
"ולפושעים יפגיע" - על ידי יסורין שבאת טל ידו טובה לעולם

Por isso, - por que ele fez isto, eu repartirei com ele uma herança e o destino com muitos com os primeiros pais - por ter entregado a sua alma na morte - a expressão como: despejou seu 
jarro (Gn 24.20) - e ter sido contado com os transgressores - ele carregou tormentos, como se ele tivesse pecado e transgredido, e isto foi por causa dos outros. Ele carregou o pecado de muitos - e pelos transgressores intercederá - por meio dos sofrimentos foi que veio, por meio dele, o bem ao mundo. 


\section{Traduções-interpretações modernas do texto e Isaías 52.13-53.12}

Abaixo analisaremos duas traduções-interpretações da perícope de Is 52.13-53.12. A da Editora e Livraria Sêfer (2006), representando uma tradução-interpretação de linha judaica e a da Editora Mundo Cristão (2010), representando uma tradução-interpretação de linha protestante.

\subsection{Tradução judaica da Editora e Livraria Sêfer}

52.13 Eis que há de prosperar o Meu servo (o povo de Israel); será exaltado e há de se elevar bem alto. 14 Assim como antes, multidões ficavam estarrecidas ao vê-lo, (dizendo:) 'Sua aparência está desfigurada e não parece humana sua forma'. 15 Assim, muitas nações admirar-se-ão depois, e reis se calarão perante ele, porque verão o que jamais lhes fora previsto e perceberão o que nunca haviam escutado:

53.1 Quem teria acreditado no que nós (as nações) ouvimos, e para quem foi revelada a ação do Eterno? 2 Porque ele (o povo de Israel) brotou como planta tenra e como raiz em terra seca. Não tinha nem forma nem beleza; era visível que não tinha boa aparência; quem o apreciaria? 3 Foi depreciado e abandonado por todos, como uma pessoa atormentada e constantemente enferma, como alguém de quem escondemos nossa face, sendo desprezado e desconsiderado. $4 \mathrm{Na}$ verdade, eram os nossos pecados sofrimentos (das nações) que (Israel) suportava, e as dores que o oprimiam, mas nós o considerávamos um ser aflito, golpeado e ferido por Deus. 5 Ferido estava, porém por nossas transgressões, e oprimido por nossas iniqüidades; seu penar era para o nosso benefício e, através de suas chagas (seu exílio), fomos curados. 6 Todos nós, como ovelhas (sem um pastor), nos desencaminhamos.Cada qual voltou-se para seu próprio caminho e (somente) sobre ele (Israel) fez o Eterno recair a iniqüidade de todos nós. 7 (Israel) foi oprimido e afligido, mas calou e não se pronunciou. Como cordeiro que é levado para a matança, e como ovelha que fica muda ante seus tosquiadores, não abriu a sua boca. 8 Com opressão e juízo iníquo foi aprisionado; acaso alguém (das nações) argumentou para com sua geração: 'Ele (Israel) foi exilado da terra dos vivos pela transgressão do meu povo,e por isso recebeu esse duro golpe? $9 \mathrm{E}$ seu túmulo foi feito entre os dos malévolos, e sua tumba feita pelos poderosos, embora não tivesse praticado violência nem houvesse mentira em sua boca. 10 Contudo, aprouve ao Eterno oprimi-lo para testar se sua alma se ofereceria como restituição, para que pudesse ver prolongados os dias de sua semente, e sentir prosperar, por seu intermédio, os desígnios do Eterno. 11 Ele percebeu o propósito e aceitou o sofrimento de sua alma. Por esta compreensão, fez reconhecer o Justíssimo perante todas as nações, suportando as iniqüidades delas. 12 Por isto, das nações separarei para ele uma porção e entre os poderosos receberá despojo, porque expôs sua alma à destruição e se deixou enumerar entre os transgressores, pois mesmo suportando os pecados de tantos, intercedeu pelos transgressores. (BÍBLIA HEBRAICA, 2006, p. 439-440) 
Nas palavras dos editores, temos as seguintes informações sobre o estilo de tradução da Bíblia Hebraica da Editora e Livraria Sêfer:

\begin{abstract}
Nossos sábios dizem que a Torá tem "70 Faces". Por isso, a tradução de um versículo em hebraico para qualquer outro idioma expressa, muitas vezes, apenas um desses aspectos, cabendo aos tradutores a ingrata e subjetiva tarefa de optar por um dos caminhos a ser seguido, deixando para trás outras excelentes opções interpretativas - certamente tão válidas quanto a apresentada nesta obra - que caberiam muito bem em notas de rodapé, o que não foi o caso, nem era a proposta deste trabalho. Mas usou-se a inserção criteriosa de certas palavras (normalmente entre parênteses) quando extremamente necessárias à compreensão do texto, ou adotou-se determinada tradução não literal a fim de possibilitar sua leitura à luz dos ensinamentos e orientações técnicas dos Sábios do Talmud e dos consagrados exegetas bíblicos judeus dos últimos 2 mil anos. (Bíblia Hebraica Sêfer, 2006, p. $8)$.
\end{abstract}

Ainda sobre a produção e princípios da tradução, Lerer diz o seguinte:

Jairo Fridlin, da Editora Sêfer, já pode respirar aliviado: dois anos depois de iniciada, está pronta a primeira edição completa do Tanach, isto é, a Bíblia judaica, em português. Ele realiza "um sonho antigo, pois os judeus falam português há pelo menos mil anos e a única versão do Tanach numa língua próxima da nossa é de 1553, editada em Ferrara, na Itália, mas em ladino. Os judeus não tinham autorização para traduzi-la para o português", conta Jairo, que editou dezenas de livros de oração, de reflexão, para crianças, leis sobre cashrut, etc. A versão em português do Tanach terá 880 páginas, capa dura de luxo e uma lombada de apenas dois centímetros e meio, porque empregou-se o chamado papel bíblia, cuja folha pesa apenas 44 gramas. O livro é uma obra coletiva. Ele o traduziu junto com David Gorodovits, do Rio, e teve a revisão técnico-religiosa dos rabinos Marcelo Borer, Daniel Touitou e Saul Paves, e dos professores Norma e Ruben Rosenberg, Daniel Presman e Marcel Berditchevsky. (Bernardo LERER in:

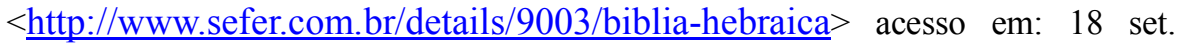
2013)

Semelhante ao comentário acima de Lerer, outros estudiosos comentam sobre a obra, enfatizando seu aspecto interpretativo e a utilização de fontes da tradição rabínica que incorporam o texto, acrescentando elementos que não fazem parte do texto hebraico da tradição massorética, mas que fazem parte da tradição interpretativa do judaísmo rabínico. ${ }^{234}$ As análises expostas no site da Editora e Livraria Sêfer, contudo, tiveram um caráter mais de divulgação e de propaganda da versão, e deixaram de enfatizar alguns aspectos importantes da tradução que procuraremos expor abaixo.

Dentre as questões que podem ser levantadas a respeito da versão, está o fato de que

\footnotetext{
234 Para as diversas apresentações da versão quando de seu lançamento vide:

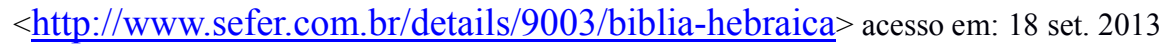


ao inserir elementos interpretativos da tradição rabínica, foi necessário escolher entre a multiplicidade de vozes da tradição, a voz que mais agradou aos editores, visto ser quase impossível inserir em uma tradução todas as vertentes interpretativas da tradição rabínica.

A inserção de parênteses no caso da perícope de Is 52.13-53.12, indica a opção mais interpretativa, ou seja, "possibilitar sua leitura à luz dos ensinamentos e orientações técnicas dos Sábios do Talmude e dos consagrados exegetas bíblicos judeus dos últimos 2 mil anos.", contudo, como visto no capítulo anterior, o Talmude nunca interpreta a perícope relacionandoa a Israel como Servo Sofredor, e os exegetas bíblicos judeus dos últimos 2 mil anos trazem diferentes interpretações a respeito da passagem, ora apresentando-a como se referindo a Israel como o Servo Sofredor, ora apresentando o Messias como tal. Como dito na citação acima dos editores, é evidente que tiveram que escolher entre a multiplicidade de interpretações entre os consagrados exegetas bíblicos judeus, e no caso da perícope em questão, a escolha foi a da interpretação do exegeta Rashi.

A inserção entre parênteses de Israel como o Servo Sofredor e as nações como interlocutoras da narrativa da perícope, embora seja a tradição interpretativa que representa a tradição mais difundida entre os exegetas rabínicos, não é a única. No capítulo sete dessa pesquisa, foram expostos vários textos antigos e até mesmo algumas correntes modernas de interpretação rabínica que entendem a perícope de Isaías 52.13-53.12 como uma referência ao Messias, entre eles: O Talmude, O Midrash de Rute, o Yalqut Shimoni, o Targum de Jônatas, Nachmânides (ver Apêndice B), Rabino Moshe Alshech, A Pesyqta Rabbaty de Rav Kahana', o Midrash Tanchuma, Maimônides, Schochet (1992, p. 41-42).

A tradição interpretativa utilizada pela Bíblia Hebraica da Livraria e Editora Sêfer é a de Rashi, curiosamente, a interpretação de Rashi também não é a mais comum, pois em sua análise, Rashi dá a entender que Israel sofre como sacrifício substitutivo ${ }^{235}$, interpretação também presente na tradução da Bíblia Hebraica da Editora e Livraria Sefer, conforme podese ler:

$4 \mathrm{Na}$ verdade, eram os nossos pecados sofrimentos (das nações) que (Israel) suportava, e as dores que o oprimiam, mas nós o considerávamos um ser aflito, golpeado e ferido por Deus. 5 Ferido estava, porém por nossas transgressões, e oprimido por nossas iniqüidades; seu penar era para o nosso benefício e, através de suas chagas (seu exílio), fomos curados.

Como o judaísmo rabínico rejeita a ideia de sacrifício substitutivo, geralmente, não é essa a interpretação adotada da passagem, o que indica, nessa passagem, a preferência da 
Bíblia Hebraica da Editora e Livraria Sêfer pela interpretação de Rashi.

A título de exemplo, outra tradução da Bíblia Hebraica feita por judeus, conhecida como The Jewish Bible (1985) e publicada pela JPS (The Jewish Publication Society), opta por uma tradução mais literal, sem inserção de elementos explicativos no corpo do texto, colocam somente breves notas de rodapé, geralmente relacionadas mais à crítica textual, citando variantes entre as versões antigas, tais como targum, LXX, Vulgata. Também citam textos paralelos da Bíblia Hebraica e algumas breves explicações interpretativas, porém, mantém o texto em sua fluidez mais próxima ao texto massorético.

Não diz respeito a presente pesquisa, a análise da obra Bíblia Hebraica da Editora Sêfer como um todo, pois isso despenderia muito espaço, porém, a versão é importante para o objeto de nossa pesquisa, visto que dentre as principais versões da Bíblia em português, a Bíblia Hebraica da Editora e Livraria Sêfer é a que mais evidentemente incorpora ao texto da perícope analisada, elementos de uma tradição interpretativa. ${ }^{236}$

\subsection{Tradução cristã protestante}

Para destacar os elementos ausentes no texto fonte, colocaremos em negrito as glosas inseridas na versão, portanto, todos os negritos do texto abaixo foram inseridos para efeito de destaque e não fazem parte do texto da Nova Bíblia Viva.

52.13 Vejam, o meu servo agirá com muita sabedoria! Ele será muito honrado e digno de admiração.

52.14 Mas muitos ficarão espantados quando o virem. Eles verão o meu servo coberto de sangue, com suas feições completamente deformadas, a ponto de nem parecer mais gente!

52.15 Até mesmo reis e nações distantes ficarão sem fala por causa dele. Pois aquilo que lhes não foi dito verão, e o que não ouviram compreenderão. Com seu sofrimento ele purificará muitas nações.

53.1 Quem creu naquilo que nós anunciamos? A quem foi revelado o poder do SENHOR?

53.2 Aos olhos de Deus ele era um pequeno ramo, brotando de uma raiz em terra seca. Mas para nós ele não tinha beleza alguma; não havia nada em sua aparência que chamasse nossa atenção ou que nos agradasse.

53.3 Ele foi desprezado e rejeitado por todos; ele era um homem que conhecia, por experiência, a dor e o sofrimento. Era como alguém que não queremos ver; ele foi

236 Curiosamente, ao discutir sobre a opção da divisão capitular, a Bíblia Hebraica da Editora e Livraria Sêfer diz o seguinte: "Um entre tantos exemplos interessantes dessa aleatoriedade é o início do capítulo 53 de Isaías, exatamente 3 versículos após o início de uma profecia (52.13), dando a entender ao leitor que ali tem início uma outra profecia totalmente desvinculada da anterior." Tal escolha revela o incômodo que a passagem traz aos editores. Sobre a polêmica da passagem no meio judaico ver Oliveira (1999, p. 22). 
desprezado, e não demos a menor importância a ele.

53.4 Apesar disso, ele tomou sobre si as nossas enfermidades, ele mesmo carregou nosso sofrimento. E nós achávamos que ele estava sendo castigado por Deus, que Deus o estava ferindo e afligindo!

53.5 A verdade, porém, é esta: Ele foi ferido por causa de nossos pecados; seu corpo foi esmagado por causa das nossas maldades. O castigo que nos trouxe a paz estava sobre ele, e pelos seus ferimentos nós fomos sarados!

53.6 Todos nós andávamos perdidos e espalhados como ovelhas! Cada um de nós seguia o seu próprio caminho; apesar disso o SENHOR fez cair sobre ele a maldade de cada um de nós.

53.7 Ele foi maltratado e humilhado, mas não disse uma única palavra! Foi levado como um cordeiro vai para o matadouro; como ovelha fica muda diante de quem corta a sua lã, ele não abriu a boca.

53.8 Foi condenado num julgamento injusto e mentiroso. E quem pode falar dos seus descendentes? Pois ele foi cortado da terra dos viventes; por causa dos pecados do meu povo, ele foi castigado!

53.9 Morreu como um criminoso e foi enterrado junto com os ricos, embora não tivesse cometido nenhuma injustiça ou tivesse dito uma só mentira.

53.10 Apesar disso, o plano perfeito do SENHOR exigia sua morte e seu sofrimento. Mas depois de dar a sua vida como oferta pelo pecado, ele verá a sua posteridade e terá vida longa; e a vontade do SENHOR prosperará em suas mãos.

53.11 E quando ele puder ver o resultado do seu terrível sofrimento, verá luz e ficará satisfeito. Através de tudo o que passou, o meu servo, o justo, fará que muitos se tornem justos diante de mim, porque ele mesmo levará sobre si os pecados deles.

53.12 Por isso, eu darei a ele grandes honras, e ele dividirá os despojos com os fortes, porque ele entregou sua vida à morte. Foi considerado um pecador; pois levou sobre si os pecados de muitos e orou em favor dos pecadores. (NOVA BÌBLIA VIVA, 2010, p. 612)

Sobre os motivos e princípios dessa tradução, lemos a seguinte apresentação, feita pelos editores:

Lançada em 1981, a Bíblia Viva foi a primeira edição brasileira da Bíblia Sagrada a contar com linguagem simplificada e de fácil compreensão. Ela foi concebida de acordo com os princípios de tradução que serviram de base para a pioneira Living Bible (EUA, 1971).

O apelo da Bíblia Viva foi imediato, principalmente entre os jovens e pessoas recém-convertidas ao cristianismo que desconheciam os termos eruditos e as construções sintáticas formais das versões bíblicas mais antigas. Para muitos leitores, abrir a Bíblia Viva passou a ser como respirar, pela primeira vez, o ar puro da compreensão.

Duas razões motivaram esta revisão, empreendida em comum acordo entre a Sociedade Bíblica Internacional e a Editora Mundo Cristão. Em primeiro lugar, a língua portuguesa do Brasil, como todos os idiomas modernos, é dinâmica, e muda de modo incremental e constante de acordo com os hábitos de uso do público que fala, lê, ouve e escreve. Percebemos que na Bíblia Viva havia elementos de linguagem já ultrapassados. O que era moderno e comunicativo no início dos anos 1980 já não era necessariamente tão expressivo. Havia a necessidade de trazer a Bíblia efetivamente para o século 21. Em segundo lugar, determinamos a necessidade de trazer algumas opções semânticas e sintáticas da primeira edição a um alinhamento maior com as línguas originais das Escrituras. Como resultado, a 
Nova Bíblia Viva é tão simples e fácil de entender como sempre, e agora está ainda mais fiel aos originais redigidos em hebraico, aramaico e grego.

Semelhantemente aos comentários da Bíblia Hebraica da Editora e Livraria Sêfer, os comentários dos editores da Nova Bíblia Viva fazem uma abordagem mais propagandística da sua própria versão, num discurso de validação à versão, procuram associar a sua versão à fidelidade com os originais, contudo, ao analisar a versão, verificam-se breves inserções de elementos interpretativos ausentes no texto fonte da Bíblia Hebraica.

Os seguintes elementos que destacamos em negrito revelam uma tradição interpretativa cristã, como em 52.14 "Eles verão o meu servo coberto de sangue.", aqui, evidentemente, se relaciona com a descrição neotestamentária do sofrimento de Jesus Cristo na cruz. Também em 53.8 "Foi condenado num julgamento injusto e mentiroso", relaciona-se com a narrativa dos evangelhos sobre o julgamento de Jesus Cristo pelas autoridades judaicas. Em 53.10, “Apesar disso, o plano perfeito do SENHOR exigia sua morte e seu sofrimento.", revela a visão do Novo Testamento de que era propósito de Deus a morte expiatória de Jesus Cristo. Por último, em 53.11 "E quando ele puder ver o resultado do seu terrível sofrimento, verá luz e ficará satisfeito", embora não traga especificamente uma tradição interpretativa judaica, não é a leitura do texto massorético e sim uma variante encontrada na LXX e em 1 QIs ${ }^{\mathrm{a}}{ }^{237}$ Embora com menos elementos interpretativos, a Nova Bíblia Viva também revela a interferência da tradição interpretativa na tradução do texto fonte da Bíblia Hebraica. Também não é o nosso objetivo aqui analisar a tradução da Nova Bíblia Viva como um todo, mas somente como exemplo de influência da tradição interpretativa na perícope de Is 52.13-53.12.

A análise dessas duas traduções-interpretações modernas da Bíblia Hebraica revelam a grande influência da tradição interpretativa, tanto da vertente judaico-rabínica, quanto da evangélica-cristã, ou seja, mesmo em uma era de vasta literatura que trata de teorias de tradução, de princípios e procedimentos de tradução mais ajustados a um ponto de vista acadêmico e de método científico, a interferência da tradição interpretativa ainda se faz presente nessas vertentes religiosas pela necessidade de se manter a leitura do texto sagrado mais próximo à interpretação de cada tradição religiosa. 


\section{Considerações Finais}

A presente pesquisa procurou demonstrar a interferência da tradição interpretativa na tradução e interpretação da Bíblia Hebraica, dentro das tradições cristãs, principalmente a protestante, e na tradição judaica rabínica. Analisamos como essas duas vertentes de tradição religiosa, moldaram suas traduções de forma que se adaptassem às suas tradições interpretativas, principalmente em textos messiânicos, que são o principal ponto de contato entre o judaísmo e o cristianismo.

Sendo a Bíblia Hebraica, considerada um texto sagrado, é reconhecido dentro da teoria de tradução, como texto sensível, pois é gerador de doutrinas, comportamentos e visões de mundo de importantes tradições religiosas, tais como as do judaísmo rabínico e do cristianismo protestante.

Devido a essa sensibilidade do texto da Bíblia hebraica, verificamos que a sua tradução é fonte de grandes debates entre as correntes religiosas, pois cada uma procura uma tradução que mais se aproxime da sua visão religiosa e da defesa de seus pensamentos.

A tradução da Bíblia também influenciou os meios seculares de estudo de tradução, pois alguns teóricos de tradução como Nida e Taber, desenvolveram suas teorias de tradução tendo por base o texto da Bíblia, tanto a chamada Bíblia Hebraica, quanto o Novo Testamento Grego.

O desenvolvimento da teoria das equivalências por Nida, foi, e continua sendo, o princípio orientador de diversas traduções da Bíblia em várias línguas, e como foi abordado no capítulo 1, a Sociedade Bíblica do Brasil, maior produtora de Bíblias no Brasil, adotou em sua BLH e a NTLH, os princípios de tradução por equivalência dinâmica de Nida, exaltando a teoria e utilizando-a como veículo de propaganda de sua versão, em contraste com as antigas versões, como ARC, ACF e ARA, definidas como tendo sido feitas por equivalência formal.

Ainda que na época da produção da BLH a teoria de Nida fosse utilizada como um princípio de tradução "moderno", com o tempo, se tornou criticada pelo meio secular como uma visão ultrapassada de princípios de tradução, principalmente pelos teóricos do discurso que classificam essas teorias de acordo com a visão logocêntrica, termo utilizado por Arrojo (1993), mas que remonta à abordagem linguística de Derridá.

Novas abordagens, dentro do próprio conceito de equivalência, foram posteriormente desenvolvidas por Baker (1994), Basset (2003), entre outros, que procuraram corrigir a abordagem de Nida ampliando o conceito de tradução não somente no âmbito da equivalência 
da palavra, mas, também, um conceito de equivalência que incluíssem outros aspectos da linguagem e do texto.

O que se procurou verificar nessa pesquisa, é que as teorias de tradução foram usadas pelas tradições religiosas para a produção de teologia, incorporando ou não elementos teóricos seculares para defender a tradição interpretativa de determinados textos da Bíblia Hebraica. Dentre os textos que se notou uma tradução com forte influência teológica, o texto de Is 14.12, analisado no capítulo 2, evidencia-se como depositário de uma tradição de interpretação protestante a respeito da queda de Satanás, influenciada pela teologia, as traduções criaram até mesmo um novo nome para Satanás, ausente na Bíblia Hebraica, mas presente na Vulgata, embora até mesmo esta, sendo mal interpretada pela tradição cristã. Mais do que tradução, verificou-se que as versões que utilizam o substantivo lucifer, como um nome: Lúcifer, continuam uma tradição interpretativa, ao invés de traduzirem o texto hebraico.

Essa presença da teologia nas traduções de outras vertentes religiosas, foi verificada, no caso da tradição judaica, na tradição interpretativa de Is 9.5-6, que remonta a interpretação do Talmude Bavli e de Rashi da mesma passagem, a versão da Editora e Livraria Sêfer incorporou em sua tradução, através da inserção de parênteses, a tradição interpretativa judaica, abordada no capítulo 2.2.

Outra corrente religiosa conhecida como Os Testemunhas de Jeová evidenciam a interferência teológica em sua tradução chamada de Tradução do Novo Mundo das Escrituras Sagradas, no caso analisado de Gn 1.2, foi observada a presença de glosas para introduzir pontos de vista teológicos a respeito do espírito de Deus e, em Gn 7.15, outras glosas introduzem a visão teológica dessa corrente religiosa a respeito da alma humana.

Todos os exemplos analisados, demonstram que a tradução pode ser despositária de uma tradição interpretativa, que interfere em sua produção, orientando o texto sensível da Bíblia Hebraica para produzir a visão teológica da tradição religiosa que a produz.

Ainda analisando a presença da tradição na produção de traduções da Bíblia Hebraica, a pesquisa verificou o uso da paráfrase, ou a tradução explicativa, para produzir, além de uma tradução, também uma explicação do texto, quer como argumento de facilitação da leitura ou como elemento interpretativo da tradição religiosa. Os exemplos analisados do salmo 23 na NTLH (2000) e na Nova Bíblia Viva (2010) verificaram a inserção de elementos parafraseados que acabaram por ampliar o texto original, explicando mais do que traduzindo.

O presente trabalho analisou também a tradução como tradição interpretativa. Do ponto de vista cristão, vista como essencial à disseminação das doutrinas cristãs, e do ponto 
de vista rabínico, vista com certo cuidado, pelo fato de diferentes versões poderem carregar diferentes versões do original (SHIMON-SHOSHAM, 2007, p. 2). Nessa abordagem, nota-se o poder da tradição como elemento gerador de tradições interpretativas estabelecidas, que acabam por interferir no processo de tradução. Para verificar essa presença da tradição interpretativa, a presente pesquisa delineou um breve histórico dos princípios de interpretação na tradição cristã e na tradição rabínica.

$\mathrm{Na}$ história da interpretação, o cristianismo precisou adaptar o texto da Bíblia Hebraica, relacionando-o com a pessoa de Jesus Cristo, e produzindo um primeiro texto interpretativo da Bíblia Hebraica, conhecido pelos cristãos como Novo Testamento. A partir do Novo Testamento, e privilegiando as versões gregas que já continham uma interpretação messiânica, os primeiros cristãos, focaram sua atenção nessas interpretações e mantiveram essa tradição interpretativa, através de comentários e exposições de cunho mais alegórico, na conhecida escola de Alexandria, e de cunho mais literalista, na escola de Antioquia da Síria. A escola intermediária, chamada Escola Ocidental, oscilou entre a interpretação literal e a alegória, contudo, o fato evidente, é que o cristianismo estava principalmente focado na questão messiânica, e seus comentários e traduções, procuraram perpetuar a tradição interpretativa que enfatizasse essa visão.

Dentro da vertente religiosa do judaísmo rabínico, também foram produzidas novas traduções gregas, que também procuravam manter uma tradição interpretativa mais literal, e menos focada na questão messiânica, enfatizando, principalmente, o estudo da Torá e suas aplicações legais (halakkah). Dentro dessa vertente, a obra mais significativa foi a Mishná, que perpetuou a tradição interpretativa do judaísmo rabínico, iniciando uma cadeia de tradição, que produziu uma enorme quantidade de material interpretativo, posteriormente aumentado pela Guemará (Talmude), e pelos diversos comentaristas rabínicos.

Entendendo que a tradição é um processo que se desenvolve ao longo de vários anos, procurou-se verificar o desenvolvimento das tradições interpretativas nas versões antigas mais importantes: a LXX, Vulgata, Targum, Peshitta e NT, foram colocados os textos dessas versões ao lado de uma tradução feita por nós e as explicações a respeito das interpretações presentes nessas versões em relação a perícope de Is 52.13-53.12. Essa análise verifica a presença de interpretações antigas desse texto que conduziram a interpretação dessa passagem também nas traduções modernas. Dentre as versões que mais preservaram a tradição interpretativa, está a LXX, de origem judaica, mas posteriormente apropriada pelos cristãos, e por isso, abandonada pelo judaísmo rabínico. A Vulgata e os Targumim, foram também, versões com forte tradição interpretativa. No caso do targum, de origem judaica, foi usado 
como fundamentação tanto das doutrinas cristãs, como das doutrinas do judaísmo rabínico.

Após essa análise das principais versões, verificou-se também que o texto da perícope em questão foi interpretado de diferentes formas pelas fontes judaico-cristãs, ora interpretando a passagem como se referindo a Jesus, como o Messias, na tradição interpretativa do cristianismo, ora se referindo ao povo de Israel na tradição interpretativa rabínica. Mas nota-se, nessa pesquisa, que a interpretação messiânica da passagem também está presente nas fontes judaicas antigas, que embora prefiram a interpretação coletiva, não deixam de abordar a possibilidade de uma interpretação individual do texto.

Ao fazer um estudo comparativo das versões do texto da perícope de Isaías 52.1353.12, pudemos verificar a forte influência da tradição na interpretação desse texto, tanto nas versões de origem cristã (NT e Vulgata), quanto nas versões de origem judaica (Áquila, Targum). Essas antigas versões formaram a base de fundamentação até mesmo para novas versões da Bíblia Hebraica, nas diferentes tradições religiosas, que as usam como referencial de suas tradições, inclusive para defender suas interpretações da perícope em questão.

Por fim, a análise de duas traduções modernas da Bíblia Hebraica, a primeira da Editora e Livraria Sêfer (BÍBLIA HEBRAICA, 2006, p. 439-440), de corrente judaica, e a segunda da Editora Mundo Cristão (NOVA BÍBLIA VIVA, 2010, p. 612), demonstram a presença da escolha de uma tradição interpretativa dentre as muitas visões do texto. Essa escolha interpretativa interferiu na produção de ambas as traduções, produzindo um texto mais explicativo, de acordo com as interpretações preferidas de cada vertente religiosa.

Observando todos esses vários aspectos desenvolvidos nessa pesquisa, podemos entender que a tradução, longe de ser transparente, é fruto das influências dos tradutores, pois carregam suas visões de mundo. Contudo, tais influências se intensificam quando a tradução trabalha com o texto sensível da Bíblia Hebraica, e se intensifica ainda mais quando se trata de textos polêmicos, ainda mais sensíveis à interferência da tradição interpretativa.

Dentro desse espectro de influência, conclui-se por essa pesquisa, que a tradição interpretativa gerou uma forte interferência na tradução do texto de Is 52.13-53.12, conduzindo o entendimento do texto de acordo com a vertente religiosa que produz a tradução da respectiva passagem. Sendo assim, o que o leitor da Bíblia Hebraica lê, já não é mais uma tradução do texto hebraico de acordo com princípios acadêmicos de tradução e de acordo com o método científico, mas sim uma tradição interpretativa que será orientada de acordo com a corrente religiosa e da preferência dos tradutores e editores da tradição interpretativa que a produz. 
APÊNDICES 


\section{APÊNDICE A}

Tradução Interlinear Literal de Isaías 52.13-53.12

$\begin{array}{ll}\text { muito } & \text { e será elevado }\end{array}$

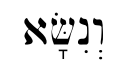

e será engrandecido

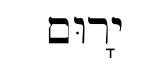

será exaltado

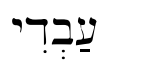

meu servo

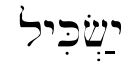

agirá com prudência
הנ:ה

eis

\begin{tabular}{|c|c|c|c|c|c|}
\hline \multirow{4}{*}{ 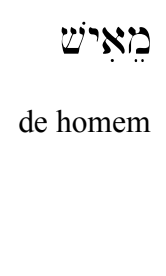 } & \multirow{4}{*}{ 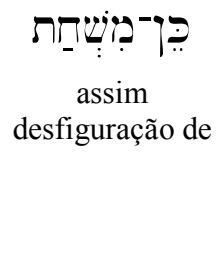 } & רברים & עַליר & 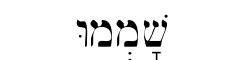 & 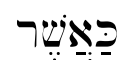 \\
\hline & & muitos & sobre ti & ficarão espantados & como \\
\hline & & אדם: אד אר & פטבני & ותארוֹ & פראהוּ \\
\hline & & homem & do [que] filhos do & e a forma dele & $\begin{array}{l}\text { aparência } \\
\text { dele }\end{array}$ \\
\hline
\end{tabular}

\begin{tabular}{|c|c|c|c|c|c|c|c|}
\hline 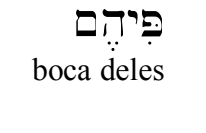 & $\begin{array}{c}\text { פִּרְבִים } \\
\text { reis }\end{array}$ & 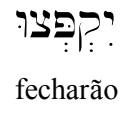 & $\begin{array}{c}\underset{T}{\operatorname{Ty}} \\
\text { sobre ele }\end{array}$ & $\begin{array}{l}\text { רבריםיר } \\
\text { muitos }\end{array}$ & $\begin{array}{l}\text { גוּים } \\
\text { povos }\end{array}$ & $\begin{array}{c}\text { cị } \\
\text { borrifará[?] } \\
\text { [espantará] }\end{array}$ & כין \\
\hline הִתחבוֹנָנגוּ: & 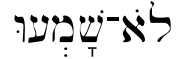 & 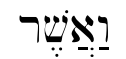 & ראיאי & לְיהם & 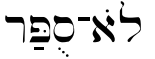 & אָאֵֶּׁר & \\
\hline & n & que & & a eles & $\begin{array}{l}\text { não foi } \\
\text { contado }\end{array}$ & o que & \\
\hline
\end{tabular}

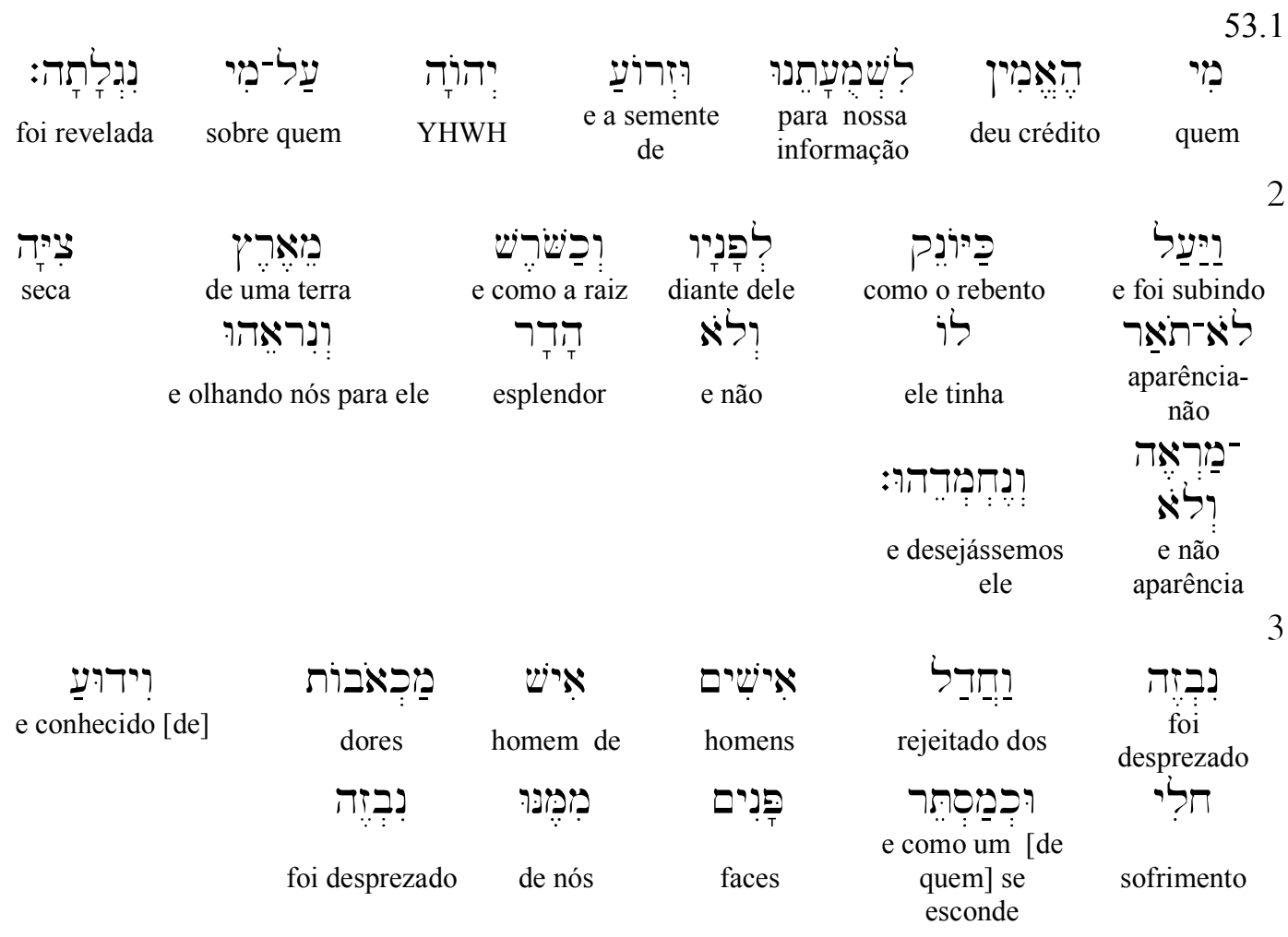




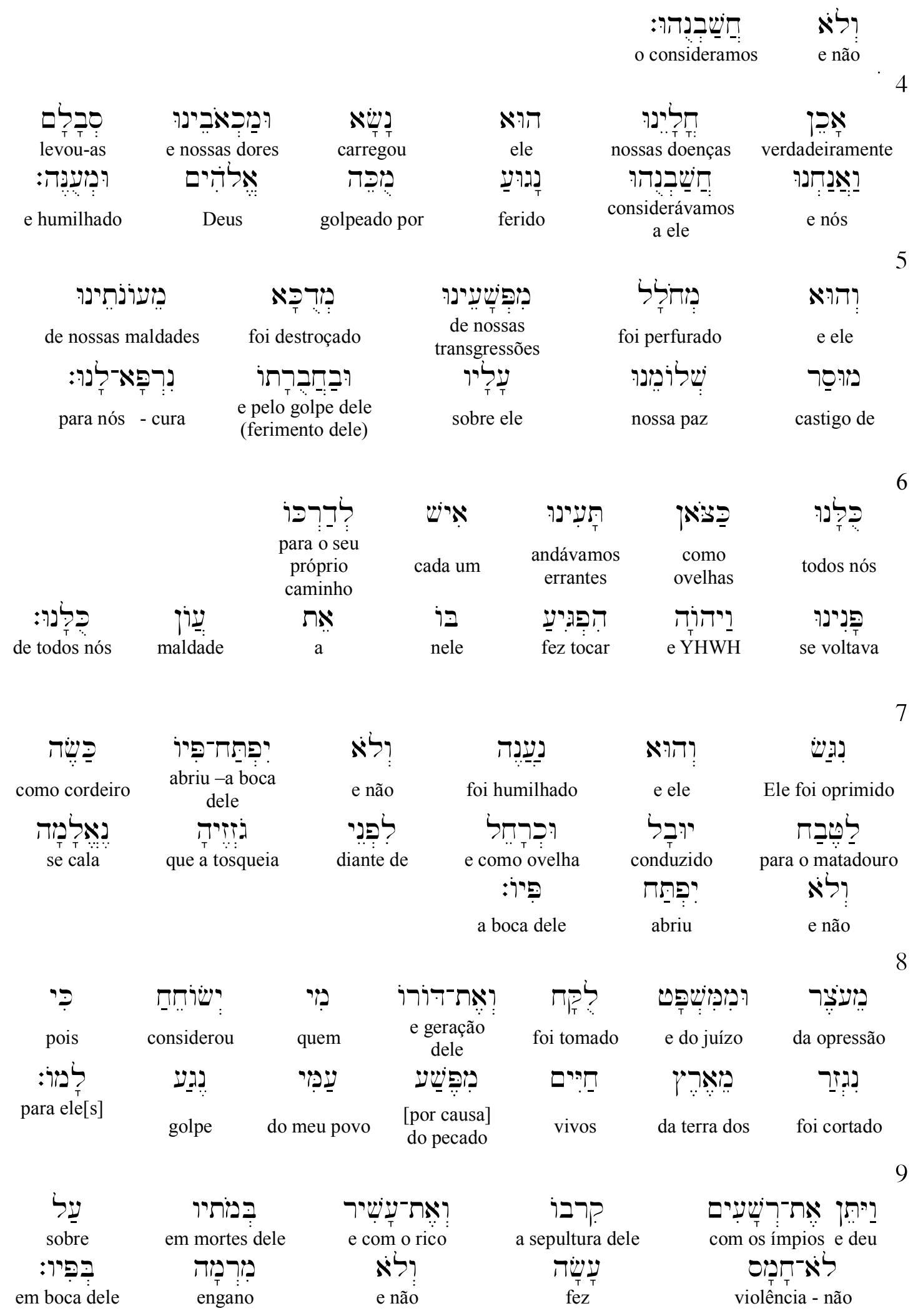




\begin{tabular}{|c|c|c|c|c|c|c|c|}
\hline & & 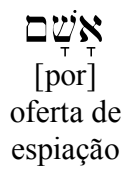 & 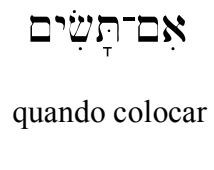 & 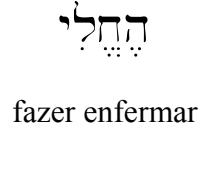 & 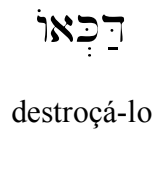 & $\begin{array}{l}r \underset{T}{Y T_{T}} \\
\text { desejou }\end{array}$ & בַייהוֹה \\
\hline \multirow{2}{*}{$\begin{array}{c}\text { פבידר } \\
\text { em mã்o } \\
\text { dele }\end{array}$} & יחהוֹה & 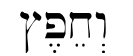 & 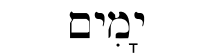 & -איארִין & זְרבעי & ירְיָה & 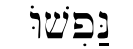 \\
\hline & YHWH & $\begin{array}{c}\text { e a } \\
\text { alegria } \\
\text { de }\end{array}$ & dias & $\begin{array}{l}\text { Ele fará } \\
\text { prolongar }\end{array}$ & semente & ele verá & alma dele \\
\hline
\end{tabular}

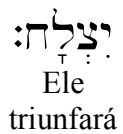

\begin{tabular}{|c|c|c|c|c|c|}
\hline ביבְִּדייק & 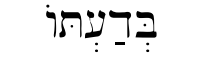 & ישרביע. & יִרְִאִה & נַבְשׁ" & 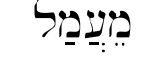 \\
\hline tornará justo & $\begin{array}{c}\text { com o } \\
\text { conhecimento } \\
\text { dele }\end{array}$ & $\begin{array}{l}\text { e estará } \\
\text { satisfeito }\end{array}$ & verá & da alma dele & do trabalho \\
\hline יםְבְל:ל: & הוּאוא & רוּעַוֹנדתחם & לדברבים & עַבְרִדי & צְִִַיק \\
\hline carregará & ele & $\begin{array}{l}\text { e a maldade } \\
\text { deles }\end{array}$ & a muitos & meu servo & sto \\
\hline
\end{tabular}

\begin{tabular}{|c|c|c|c|c|c|c|}
\hline & & יחקר?ק & 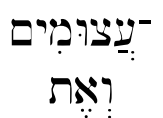 & רדרברים & 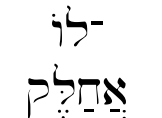 & לברן \\
\hline & & ele repartirá & $\begin{array}{l}\text { e com os } \\
\text { poderosos }\end{array}$ & com muitos & $\begin{array}{l}\text { eu } \\
\text { repartirei } \\
\text { com ele }\end{array}$ & por isso \\
\hline \multirow{4}{*}{ 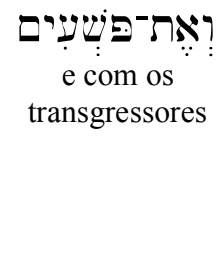 } & נַבְשׁוֹ & לַּפְּרִת & הִעירדה & 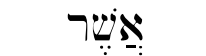 & תַתַחת & שְַׁׁל \\
\hline & alma dele & na morte & entregou & que & debaixo de & despojo \\
\hline & 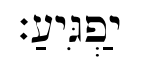 & 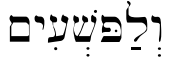 & נדשיא & 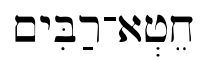 & וְהוּאוא & נְְִּנָה \\
\hline & $\begin{array}{c}\text { fará } \\
\text { intercessão }\end{array}$ & $\begin{array}{c}\text { e pelos } \\
\text { transgressores }\end{array}$ & carregará & $\begin{array}{l}\text { o pecado de } \\
\text { muitos }\end{array}$ & e ele & $\begin{array}{c}\text { foi } \\
\text { contado }\end{array}$ \\
\hline
\end{tabular}




\begin{abstract}
APÊNDICE B

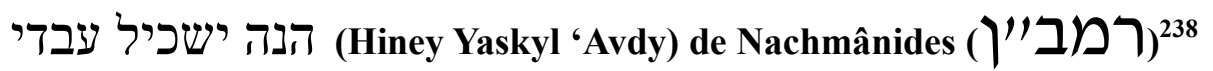

\title{
באור פרשת הנה ישכיל עבדי
}

הנה ישכיל עבדי, הנכון בפרשה הזאת שהיא על ישראל כלו, כלשון אל תירא עבדי יעקב , ויאמר לי עבדי אתה ישראל אשר בך אתפאר וכן רבים .אבל על דעת המדרש המיחס אותה על משיח, צריכים אנו לפרש אותה כפי דברי הספרים. פיי אחד, אומר שמשיח בן דויד שבו דבר הכתוב לא ינוצח ולא יומת ביד שנאיו, וכן הכתובים מורים בביאור. וזה פירוש הפרש:

הנה ישכיל עבדי, כי בעתות הגאולה יבין המשיח וישכיל הקץ וידע כי הגיע תור ביאתו ובא הקץ שיתגלה לעדת המיחלים לו. ואמר ישכיל, לפי שנאמר בספר דניאל, כי סתומים וחתומים הדברים עד עת קץ יתבררו ויתלבנו ויצרפו רבים והרשיעו רשעים ולא יבינו כל רשעים והמשכילים יבינו. אמר דניאל כי יהיו מן הרשעים שירשיעו לחרף ולגדף עקבות המשיח. בעבור איחורו הגדול, ולא יאמינו בו כלל ולא יבינו כל שי שי שי הרשעים הקץ, כי יהיו מהם שיטעו אחרי איש שיטעון שהוא משיח, והמשכילים יבינו הקץ האמיתי ויחכו אליו. וכנגד זה אמר ישעיה, כי המשיח

\footnotetext{
238 O texto utilizado é o de SHEVOEL, Rav Haim Dov (org.). Kotvey Rabeynu Moshé ben Nachman. [hebraico]. Jerusalém, Israel: Musar Harav Kook, 1963 em comparação com o texto de NEUBAUER, Vol I, 1877 , p. $75-85$, precisei ajustar as variantes textuais anotadas nesses dois textos para produzir uma tradução com um sentido lógico.
} 
עבד ה' ישכיל ויבין הקץ, ומיד יקום וירום וישא ויגבה לבו בדרכי ה' לבא לקבץ נדחי ישראל, לא בחיל ולא בכח כי אם ברוחו, אשר יבטח בה' , כענין שהיה הגואל הראשון, שבא במקלו ובתרמילו לפרעה והכה ארצו בשבט פיו. ולפי זה אמרו במדרש, ירום מאברהם, ונשא ממשה, ונוגה ממלאכי השרת. נתבוננו לומר כי המשיח ירום מאברהם, שהיה דורש אמונת האלהים ומגייר גרים בארץ נמרוד על כרחו של מלך,והמשיח יעשה יותר מזה שיגייר עמים רבים. ונשא ממשה, שבא לפרעה, המלך הגדול הרשע שאמר, לא ידעתי את ה' , והוא היה רועה שפל אנשים, ולא יירא ממנו והוציא עמו מכור הברזל, והמשיח יעשה יותר ממנו , שיתעורר על כל מלכי עולם כלו,להוציא ישראל מידם ולעשות נקמה בגוים. וגבה ממלאכי השרת, שגם המה מזרזים מאד בענין גאולתם של ישראל, כדכתיב: ואין אחד מתחזק עמי בכל אלה כי אם מיכאל שרכם , ואמר אשוב להלחם עם שר פרס וגו' שם והמשיח יעשה יותר מכולם. ויתכן החכמה למעלתו של משיח וקרבתו אל האלהים, כי אברהם שקראו ה' הנכבד והנורא , אוהבו, וכרת עמו ברית חדשה, ומשה שחיה קרוב להש"י מכל האדם, ומלאכי השרת עומדים עליו מימינו ומשמאלו, כולם אינם קרובים בידיעת הש"י כמשיח, כי כן כתיב, ועד עתיק יומי מטה וקדמוהי הקרבוהי, ובמלאכי השרת כתיב ,אלף אלפין ישמשוניה ורבוא ורבוא רבבן קדמוהי יקומון. ולכך אמר ישעיי שהוא ירום, בשכלו, אשר ישכיל מאד את הש"י, ונשא וגבה מאד, בידיעת שמו ית', יותר מכל הנבראים לפניו. וכבר אמרו אפילו בשאר צדיקים שהם גדולים יותר ממלאכי 
ואמר הכתוב במשיח, כאשר שממו עליך רבים וכו', ר"ל כאשר שממו עליך , להלעיג בך בתחלת בואך, ואמרו האיש הנבזה העני ורוכב על חמור, איך ינצח כל מלכי העולם , אשר כולם החזיקו בישראל ואיך יצילם מידם, וכן היה פרעה עושה במשה, שהיה מלעיג עליו כמו שאמר, הן בני ישראל לא שמעו אלי ואיך ישמעני פרעה . כן יזה גוים רבים יאמר כאשר יאמרו האיש הזה משחת מאיש מראהו, כן יאמרו עתה , שתהטיף מלתו עליהם ופיהם יפערו למלקוש דברו. עליו יקפצו מלכים פיהם, שיסגירו פיהם, אפילו בחדר משכיבם , יהיו יראים מלדבר עליו, ויאמרו איש אל רעהו, גם במדעך מלך אל תקלל.

מי האמין לשמועתנו, ואמר, , כאשר באה שמועת משיח בעמים, מי בהם שיאמין זה, וזרוע ה', אשר הוא מוליך לימין הגואל, כמו שהוליך לימין משה זרוע תפארת , על מי נגלתה , שיאמין בזה, כי היה מתחלה כאילו הוא אילן קטן עולה מארץ ציה , שלא יגדל לעשות ענף ולשאת פרי.

והוא נבזה , שאין לו חיל ועם, אבל עני ורוכב על חמור, כאשר היה הגואל הראשון מרע"ה בבואו למצרים הוא ואשתו ובניו על החמור. איש מכאובות , מצטער על עונות ישראל שגורמין איחור, ומונעים אותו מהיות מלך על עמו. וידוע חולי, כי החולה תמיד הוא מצטער על הכאב, והחולי יאמר על הצער הבא בסבת רוב החשק ,כמו שנאמר וידבר לאמנון להתחלות בעבור תמר אחותו, וכן אין חולה מכם עלי, או שיחלה ממש מן הצער, 
אכן חליינו הוא נשא ,כי הוא חולה, ומצטער על פשעינו שהיינו אנחנו ראויין להיות הולים ומצטערים בהם, והמכאובות שהיינו אנחנו ראויים להיות כואבים עליהן הוא סובל חזקם, כי הוא המצטער עליהם. ואנחנו חשבנוהו , בראותינו אותו דל וחלוש, כי הוא נגוע מוכה אלהים

ומעונה.

והוא מחולל, מלשון יחולל אילות מוסר השלום עליו , כי מוכיח בו. ובחבורתו נרפא לנו , כי החבורה שהוא מצטער ומתגורר עליה תרפא אותנו, כי השם יסלח לנו בזכותו, ונתרפא מפשעינו ועוונות אבותינו, מלשון ושב ורפא לו, שלום שלום לרחוק ולקרוב אמר ה' ורפאתיו, וכל הלשונות האלו רבים בענין הגאולה, אנוש לשברך נחלה מכתך , אין דן דינך למזור רפאות תעלה אין לך.

כולנו כצאן תעינו איש לדרכו פנינו , יאשים את ישראל בעבור כי הם בגלותם ישימו כל כוונתם בעסקי העולם , ומשים כל אחד כוונה לעצמו ביתו ועסקיו, וראוי להם להיות בוכים ולהתפלל לפני ה' לילה ויום שיכפר על העוון ישראל ויחיש קץ הגאולה, כי המשיח יבוא בתשובה יבוא מיד, ואם לאו, יתאחר עד הקץ הבא עליו בשבועה כדכתיב , וירם ימינו ושמאלו אל השמים וישבע בחי העולם . ונאמר: וה' הפגיע בו את עון כולנו , כי העון הזה הנזכר פוגע בו, כי הוא מצטער כל היום על כי איחרו פעמי מרכבותיו, ואנחנו אין אנחנו משגיחים בכך, אלא מתעסקין בעסקים בתוך 
נגש והוא נענה , כי בבואו בתחילה עני ורוכב על חמור, יבואו עליו נוגשי כל עיר ועיר ושוטריו ויענו אותו בחירופין וגדופין, כי יחרפו אותו ואת האלהים אשר הוא בא בשמו, כענין משה רבינו שאמר לו פרעה , לא ידעתי את ה' , והוא לא ענה אותו ולא אמר לו, אלהי השמים והארץ אשר ישמידך מהר, אבל שתק , וכן משיח לא יענה, וישתוק. ולא יחדל מלדרוש לישראל, ומלומר לכל מלך שבאומות , כה אמר ה' שלח עמי ויעבדוני, והוא כשה לטבח יובל, יחשוב בלבו אפילו יהרגוני אעשה שליחות בוראי, כי כן חובה עלי, כמו שאמר חנניה מישאל ועזריה , והן לא ידיע להוי לך מלכא וגו' וכן אמר רז"ל, כל המוסר עצמו על מנת להעשות לו נס אין עושין לו נס. ובלשון הזה בעצמו אמר ירמיה , ואני בכבש אלוף יובל לטבוח , וכן אמר אסוף המשורר, ואהי נגוע כל היום , ואומר, כמו חללים שוכני קבר.

מעוצר וממשפט לוקח , יחשוב בלבו שלוקח מלעצור בעמו ומהיות שר ושופט עליהם, ויחשוב: ואת דורו מי ישוחח, שיספר להם ויודיעם דרכי הש"י, ויאמר כי אני נגזר מארץ חיים ,בעבור פשע עמו שהוא הנגע שלהם. וסיפר הכתוב בשבחו , שלא ידאג על חייו רק בעבור ישראל.

ויתן את רשעים קברו , הנתינה תאמור בכתוב - על גמר המחשבה בלב, נתתי את לבי לדרוש, אל תתן אמתך , ותאמר על הדבור, כמו ונתת את הברכה על הר גריזים , ונתן אותם על ראש השעיר. אמר, יתן בלבו 
שיהיה קברו עם הרשעי האומות, כי יחשוב ויאמר ודאי יהרגוני ובמקום הזה תהיה קבורתי, כמו וחוצבי מרום קברו, שר"ל המקום שיחשוב שנקבר בו

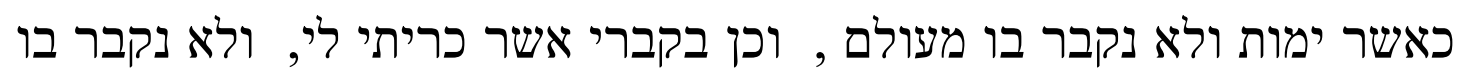
עדיין.

ואת עשיר במותיו, יאמר שיתן לנפשו מיתות הרבה , עשירי השלוה שבישראל שאינם חפצים בו, כי יחשוב שיהרגוהו בסקילה או בשרפה הרג וחנק, לכך אמר במותיו, לשון רבים, וזה כדרך המתים בחושך מצרים. ואמר, על לא חמo עשה, לרשעים הנזכרים, שהם האומות, שלא בא לגזול דבר משלהם, ולא מרמה בפיו, לעשירי ישראל.

וה' חפץ דכאו החלי, כי רצה הש"י לזכותו בצער שהוא מצטער בו. שתשים נפשו אשם, שיחשוב בו כי אשם וחטא ובעבור מיעוט זכותו אירע כל זה, כי יהיי לו זכות שלימה בזה, וטעם אם תשים , הם דברי השם הנכבד והנורא וחפצו, שאמר שאם יסבול כל זה ותהיה נפשו שפלה, שלא יקרא תגר וחרהור אחרי מדותיו, הנה אתן לו שכר מדה כנגד מדה, שיראה זרע, ואמרו: אם, כמו אם תשוב ואשיבך לפני תעמוד. יראה זרע, ויתקיים בו קרא דכתיב תחת אבותיך יהיו בניך תשיתמו לשרים בכל הארץ , ויאריך ימים לעדי עד עולם, כמו שנאמר, חיים שאל ממך נתת לו אורך ימים עולם ועד , וכן אמר בפרקי דר"א הגדול, דכתיב שנותיו כמו דור ודור . וחפץ ה' בידו יצלח, כי הוא ישלים הגאולה אשר הש"י חפץ בה, וילמד לכל העמים להשכיל ולדעת את ה' וחפץ ה' , כמו שנאמר כי באלה חפצתי נאום ה'. 
מעמל נפשו יראה ישבע , יאמר כי בעבור העמל שראה בעצמו ושבע קלון מכבוד, ובזכות זה, בדעתו יצדיק צדיק , כי הוא ידע ויכיר מי ומי הם הצדיקים הראוים להגאל, וכן כל משפטיו, ובין צדיקים, כמו שנאמר, והריחו ביראת ה' וכו' ישפט בצדק דלים וכו'. ועוונותם של רבים הנזכרים, הוא סבלם, כי יתקן בהם תשובה, כמו לכל סבל בית יוסף , שר"ל תיקון ענינים, וכן לכו לסבלותיכם.

לכן אחלק לו ברבים, שיהיו כל עמים רבים חלקו ונחלתו, ומן הגוים עצומים יחלק שלל לעמו ולעבדיו. תחת אשר הערה למות נפשו, שריקן נפשו מכל דבר למיתה, כלומר שגמר בדעתו למות, שמסר עצמו על מנת למות, מלשון אל תער נפשי, שר"ל אל תרוקן אותה מחשקה, ומאשר היא מתאוה לראות , כי תשלום הרצון יקרא מילוי הנפש, כלשון תמלאמו נפשי, וביטול החשק נקרא עירוי הנפש. ואת פושעים נמנה, ותחת שנמנה בלבו שכל להיות מכלל הפושעים , כאשר הזכרתי. והוא חטא רבים נשא בעת ההיא, כי לא על פשעיו היה לו רק על חטאם. ולפושעים יפגיע , שיפגיע הוא בנפשו עון החוטאים והפושעים, כמו וה' הפגיע בו את עון כולנו.

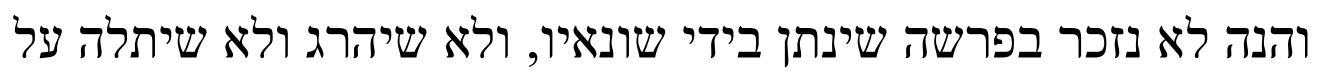
עץ, אלא שיראה זרע ויאריך ימים, וירום ונשא מלכותו בין בגוים, ומלכים עצומים יהיו לו לשלל, אמן ואמן סלה בבי"א. 


\section{Tradução $^{239}$}

\section{Esclarecimento sobre a interpretação da perícope "Hineh Yaskîl 'Avdî”"}

Eis que agirá com prudência meu servo, a correta interpretação desta parashá diz respeito a Israel como um todo, conforme a expressão não temas meu servo Jacó, e disse-me: tu és meu servo, Israel, que em ti eu serei glorificado (Is 44.2, 49.3) e assim [em] muitos [outros lugares]. Mas o conhecimento do Midrash atribui essa passagem ao Messias, nós precisamos interpretá-la conforme as palavras dos livros. O profeta diz que o Messias, filho de Davi, a respeito do qual o texto fala, não será vencido e não morrerá nas mãos de seus inimigos, e, assim, os escritos ensinam claramente.

E esta é a interpretação da passagem:

Eis que agirá com prudência meu servo, pois, no tempo da redenção, o Messias terá entendimento e agirá com prudência, o fim conhecerá, pois saberá quando o período para isto estiver chegando perto. E diz: agirá com prudência, de acordo com o que é dito no livro de Daniel, pois estão fechadas e seladas as palavras até o tempo do fim, serão purificados e embranquecidos e provados muitos e os ímpios agirão impiamente e não entenderão todos os ímpios (Dn 12.9) - mas os sábios entenderão (Dn 12.10). Diz Daniel: os ímpios procederão impiamente (Dn 12.10) para afrontar e para blasfemar as pisadas do Messias (S1 89.52[51]). Para atrasarem a redenção, e não crerão nele a totalidade deles e não entenderão todos os ímpios o fim, mas irão extraviar-se após qualquer um que reivindicar ser o Messias, mas os sábios perceberão o fim, conforme eu disse no debate para ele. E a respeito disso disse Isaías, pois o Messias, servo de HaShem, agirá com prudência e terá entendimento a respeito do fim, e imediatamente será exaltado e será elevado e engrandeceu o seu coração nos caminhos de HaShem (II Cr 17.6) para vir e ajuntar os dispersos de Israel, não por força e nem por violência, mas pelo meu espirito (Zc 4.6), pois confiará em HaShem, da mesma forma como o primeiro redentor, pois veio com sua vara e com sua bolsa a Faraó e ferirá a terra dele com a vara de sua boca (Is 11.4). E, de acordo com isso, é dito no Midrash, ele será maior do que Abraão, e será mais elevado do que Moisés, e mais reluzente do que o ministério dos anjos.

\footnotetext{
239 A tradução foi feita do hebraico com o auxílio da tradução para o inglês de DRIVER \& NEUBAUER,
} Vol II, 1877, p. 78-84. 
Há entendimento em dizer que o Messias será maior do que Abraão, pois buscará a fé em Deus e conquistará prosélitos na terra de Ninrod, apesar da oposição do rei, e o Messias fará mais do que conquistaram muitos povos. E será mais elevado do que Moisés, que veio a Faraó, o grande rei ímpio, e Faraó disse: não conheço HaShem, e ele era pastor e o mais humilde dos homens, e não temeu a ele e fez sair o povo dele para a fornalha de ferro, mas o Messias fará mais do que ele, pois se moverá contra todos os reis do mundo inteiro, e fará sair Israel das mãos deles para fazer vingança contra os gentios. E será maior do que o ministério dos anjos, pois também eles exercerão diligentemente a redenção de Israel, como está escrito: e não há ninguém que se anime comigo contra estes senão Miguel vosso príncipe (Dn 10.21), e diz voltarei e guerrearei contra o príncipe da Pérsia e etc. Assim, o Messias fará mais do que todos eles. E ele estabelecerá a sabedoria para a elevação do Messias e a aproximação dele a Deus, pois Abraão como se lê: HaShem, o glorioso e temido, amigo dele, (Is 41.8), e firmou com o povo dele uma nova aliança, e Moisés, que viveu mais próximo de HaShem do que qualquer homem, e o ministério dos anjos que estão parados diante dele, à sua direita e à sua esquerda (I Re 22.19), de todos eles nenhum se aproxima do conhecimento do Todo-Poderoso como o Messias, pois assim está escrito, e até o ancião de dias fizeram chegar até ele (Dn 7.13), e sobre o ministério dos anjos está escrito, milhares de milhares o serviam e milhões de milhões assistiam diante dele. E ainda diz Isaías que ele será grande, em seu entendimento, pois agirá com prudência por meio ${ }^{240}$ de HaShem, será elevado e muito grande, no conhecimento do seu bendito nome, mais do que todos os que nasceram antes dele. E foi dito ainda que o restante dos justos que serão maiores do que o ministério dos anjos.

E diz a escritura a respeito do Messias, como ficarão espantados sobre ti muitos, etc., quando ficarem espantados sobre ti, quer dizer: escarnecerão de ti em tua primeira vinda, e está dito: pobre homem miserável e sentado sobre um jumento (Zc 9.9), como poderá vencer todos os reis do mundo? Pois todos eles se fortaleceram contra Israel, e como salvá-los das mãos deles, assim fazia Faraó com Moisés, pois zombava dele, como está dito, Eis que os filhos de Israel me têm ouvido e como serei ouvido por Faraó? (Êx 6.12). Assim borrifará muitos povos, diz a respeito deste homem, que a visão deste homem está desfigurada, assim está dito agora, que dispersará a palavra dele sobre eles e eles abrirão os lábios deles para [receber] a chuva das palavras dele (Jó 29.22, 23). Sobre ele fecharão reis as bocas deles. 
Pois eles fecharão as bocas deles, até na câmara das imaginações deles (Ez 8.12), terão temor de falar a respeito dele, e dirão um ao outro, nem em ti haja maldição contra o rei (Ec 10.20).

Quem deu crédito à nossa informação e diz, pois vem a notícia do Messias aos povos, quem dentre eles creu nisto, e o braço de HaShem, pois ele conduz a mão direita do redentor, como conduz a mão direita de Moisés como um braço de majestade (Is 48.12). A quem foi revelado, que creu nisto, pois era, inicialmente, como uma pequena árvore que crescia de uma terra seca, que não cresceu [suficientemente] a ponto de produzir ramos e trazer frutos, e ele foi desprezado, pois ele não tinha um exército e nem povo, mas pobre e sentado em um jumento, assim como foi o primeiro redentor, Moisés, nosso mestre, quando entrou no Egito ele e sua mulher e os seus filhos sobre o jumento (Êx 4.20). Homem de dores, ele foi afligido pelas iniquidades de Israel por causa do atraso, pois eles impediram-lhe de ser rei sobre o povo dele. E experimentado em enfermidades, pois a enfermidade faz com que ele sempre sofra dores, e a palavra enfermidade é usada aqui a respeito da dor produzida por excessivo amor, como é dito: e disse a respeito de Amnon que [ele angustiou-se] até adoecer por Tamar a irmã dele, e assim que não há enfermidade de vocês sobre mim ou que ele estará enfermo frequentemente por causa da dor, como trazida pelos seres humanos.

Verdadeiramente as nossas enfermidades ele carregou, pois ele estava enfermo, e angustiado pelas nossas transgressões e éramos nós que deveríamos estar enfermos e angustiados por causa dele. E as dores que nós tínhamos deveria estar essas dores sobre eles, ele levou esforçando-se por eles, pois ele se fez angustiar por causa deles, e nós considerávamos ele, quando vimos ele fraco e prostrado, pois ele foi ferido, golpeado por Deus e humilhado.

E ele foi perfurado, a palavra מחולל vem de מחולל o castigo de nossa paz estava sobre ele, pois ele foi punido. E pelo golpe infligido a ele, fomos sarados, pois o golpe pelo qual ele foi angustiado e humilhado trará cura para nós, pois Deus nos perdoará por causa da justiça dele, e seremos curados das transgressões e iniquidades de nossos pais, a palavra רפא é usada novamente no sentido de que ele tem cura, paz, paz para os que estão longe e para os que estão perto, diz HaShem que saro a ele, e toda essa linguagem diz respeito a redenção, incurável a tua ferida, dolorosa a tua chaga ( $\operatorname{Jr} 30.12$ ) não há quem defenda a tua causa para te aplicar curativo, não tens remédio que te possa curar (Jr 30.13). 
Todos nós como ovelha andávamos cada um em seu próprio caminho se voltava, ele acusa Israel de ser culpado, porque eles, em seu exílio, colocaram toda a atenção deles nos negócios do mundo, e cada um dedica a si mesmo os seus próprios interesses e as ocupações de sua própria casa, e eles deveriam chorar e orando diante de HaShem de dia e de noite para expiar os pecados de Israel e apressar o fim do exílio, pois o Messias virá, em arrependimento virá em breve, se não, ele tardará até a vinda do fim, de acordo com o juramento, como está escrito: e levantou a mão direita dele e a mão esquerda dele aos céus e jurou por aquele que vive para sempre (Dn 12.7). E está dito: HaShem fez tocar nele a iniquidade de todos nós, pois esta iniquidade mencionada tocará ele, pois ele se angustiará todo o dia por se atrasarem o andar das carruagens dele (Jz 5.28), e nós, nós não temos prestado atenção nestas coisas, mas nos ocupamos entre as ocupações que há no mundo.

Ele foi oprimido e ele foi humilhado, pois tinha vindo primeiramente pobre e montado em um jumento, vieram sobre ele os capatazes de toda cidade e os oficiais da cidade torturaram a ele com divertimentos e insultos, pois reprovaram tanto a ele quanto a Deus, no nome do qual ele veio, como Moisés, nosso mestre, aquele a quem Faraó disse: Não conheço HaShem, e ele não respondeu a ele e não disse a ele, o Deus dos céus e da terra que destruirá a ti rapidamente, mas silenciou, e, assim, o Messias não responderá, e silenciou. E não deixará de exigir de Israel, dizendo a todo rei das nações, assim diz HaShem, deixa o meu povo ir para que me sirva, e ele, como cordeiro para o matadouro foi conduzido, pensará em seu coração: mesmo que eles me matem eu farei o que fui enviado a fazer por meu criador, pois assim eu devo fazer, como é dito de Hananias Misael e Azarias, e se não, fica sabendo oh rei, etc (Dn 3.18) e da mesma maneira os Rabinos dizem: 'todo o que dá a si mesmo para a morte, confiando que um sinal será feito para ele, nenhum sinal será feito para ele'. E essa linguagem é a mesma que diz Jeremias, e eu como sou cordeiro, como um boi que é levado para o matadouro (Jr 11.19), e assim é dito na canção de Asafe, pois todo dia tenho sido afligido (S1 73.14) e diz, como feridos de morte que habitam na sepultura (S1 88.5).

Da opressão e do juízo foi tomado, ele pensará em seu coração que foi tomado da detenção pelo seu povo e ter sido o príncipe e juiz sobre ele, e ele pensará que foi tomado da terra dos viventes, por causa da transgressão do povo dele, que ele foi ferido por eles. E conta a escritura em seu louvor, que não se preocupe com a sua própria vida, mas somente por Israel. 
E foi entregue com os impios a sepultura dele, ele pensará em seu coração que foi tomado por causa de seu povo e por ser príncipe e juiz sobre eles, e pensará: e a sua geração quem a declarou - pois declarará a eles e eles entenderão os caminhos de HaShem, pois diz foi tirado da terra dos viventes, por causa do pecado do povo dele que ele foi ferido por causa deles, e diz a escritura, em seu louvor, que ele não se preocupará com a sua própria vida, mas somente por Israel.

E foi entregue com os ricos a sepultura dele. O verbo נתן é usado na escritura - a respeito do último pensamento do coração, entreguei meu coração para buscar (Ec 1.13), não tenhas a tua serva (I Sm 1.16), e é dito sobre a palavra, sobre dar a bênção sobre o monte Gerezim (Dt 11.29), e as colocará [as mãos] sobre a cabeça do bode (Lv 16.21). Diz, ele entregou o coração dele, que será a sepultura dele com as nações ímpias, pois pensará e dirá: certamente eles me matarão e neste lugar será a minha tumba, como [está escrito] cavando o lugar da sepultura dele (Is 22.16), não se refere ao lugar que ele pensará que foi enterrado quando ele morrer e não que ele está enterrado eternamente, e, sim, na minha sepultura que eu cavei para mim, e não foi sepultado ainda.

E com o rico em suas mortes, diz respeito a entrega de sua alma para muitas mortes, Além disso, os ricos que estão em Israel e não se agradam dele, pois ele pensará que eles o matarão por apedrejamento ou por queimadura, assassinato ou asfixia, por isso diz em suas mortes, isto é, conforme as mortes nas trevas do Egito. E diz, e não cometeu violência, os ímpios mencionados, que são gentios, e não vem para tomar algo deles, e não houve engano em seus lábios, os ricos de Israel.

E HaShem desejou destroçá-lo, fazendo-o enfermar, pois quis HaShem infligir a ele a angústia a qual ele suportou. Que colocou a alma dele como oferta de expiação, pois ele pensará que por causa da oferta de expiação e, pela oferta de pecado de uma minoria, que aconteceu tudo isso. Pois havia uma razão para concluir isso, e agradou quando colocar, estas são as corretas palavras de HaShem e são terríveis os desejos dele, pois diz que ele suportará tudo isso, será a alma dele humilhada, pois não será contencioso a respeito da razão destas medidas, eis que darei a ele a sua recompensa, medida por medida, pois ele verá a semente, como diz: se como quando é dito se tu voltares, então, te trarei diante de mim e permanecerás. (Jr 15.19) e verá uma semente, e se cumprirá o que está escrito em lugar de 
teus pais estarão os teus filhos os colocarás por príncipes em toda a terra (S1 45.17) e ele aumentará os dias, sempre e sempre, eternamente, como é dito, vida te pediu e deste a ele abundância de dias sempre e eternamente. (S1 21.5) e, assim, diz no Pirqey do Rabino Eliezer, o grande, como está escrito como muitas gerações (S1 61.7). e a alegria de HaShem em suas mãos triunfará, pois ele completará a redenção que HaShem queria, e ensinará todos os povos com prudência e entendimento de HaShem e se alegrará HaShem, como é dito, pois destas coisas me agrado, diz HaShem (Jr 9.23 (24 em português)).

Do trabalho da sua alma verá e ficará satisfeito, é dito: pois pelo trabalho que viu nele mesmo e ficou satisfeito, vergonha em vez de glória (Hc 2.16), e graças a isto com o seu conhecimento justificará o justo, pois ele saberá e conhecerá quem e quem são os justos que deverão ser redimidos, e, assim, todo o juízo dele e entre os justos, como é dito e irá deleitarse no temor de HaShem e etc. (Is 11.3) julgará com justiça os pobres (Is 11.4) e nossas iniquidades, como mencionado anteriormente, de muitos, ele as suportará, pois irá corrigi-los para o arrependimento, como tudo pôs a cargo da casa de José (I Re 11.28), significa acerto de contas, assim com é dito ide às vossas cargas (Êx 5.4).

Por isso, dividirei com ele a porção de muitos, pois a totalidade de muitas nações (S1 89.51) será a porção e herança dele, $e$ do meio dos gentios ele dividirá o forte espólio para o povo dele e para os servos dele, pois ele esvaziou a sua alma de tudo para morrer, isto é, ele resolveu em sua mente resignar-se à morte. Conforme a linguagem não deixe derramar minha alma (S1 141.8), isto é, esvaziá-la da esperança, a qual demora a se realizar, pois o cumprimento da vontade é dito como sendo o sentimento da alma, como na linguagem de será satisfeito o meu desejo (Êx 15.9), semelhantemente a frustração do desejo é chamada de esvaziamento da alma. E com os transgressores foi numerado, esperava em seu coração, que fosse contado no meio dos ímpios, conforme eu já havia afirmado. E ele, o pecado de muitos suportou, naquele tempo, pois não diz respeito às iniquidades dele, mas a respeito do pecado dos outros. E pelos transgressores intercederá, intercederá, isto é, a maldade dos pecadores e dos ímpios, como HaShem fez chegar a ele a iniquidade de todos nós.

Eis que não faz menção, na parashá que será entregue nas mãos de seus inimigos, e não será morto e não será pendurado em uma árvore, mas que verá a semente e se estenderá por muitos dias, e será exaltado e elevado e o reino dele estará entre as nações, e ele terá o סלה בבי"א 


\section{ANEXOS}


ANEXO A

MIDRASH DE RUTH RABA CONTENDO A INTERPRETAÇÃO DE ISAÍAS 52.13-53.12 


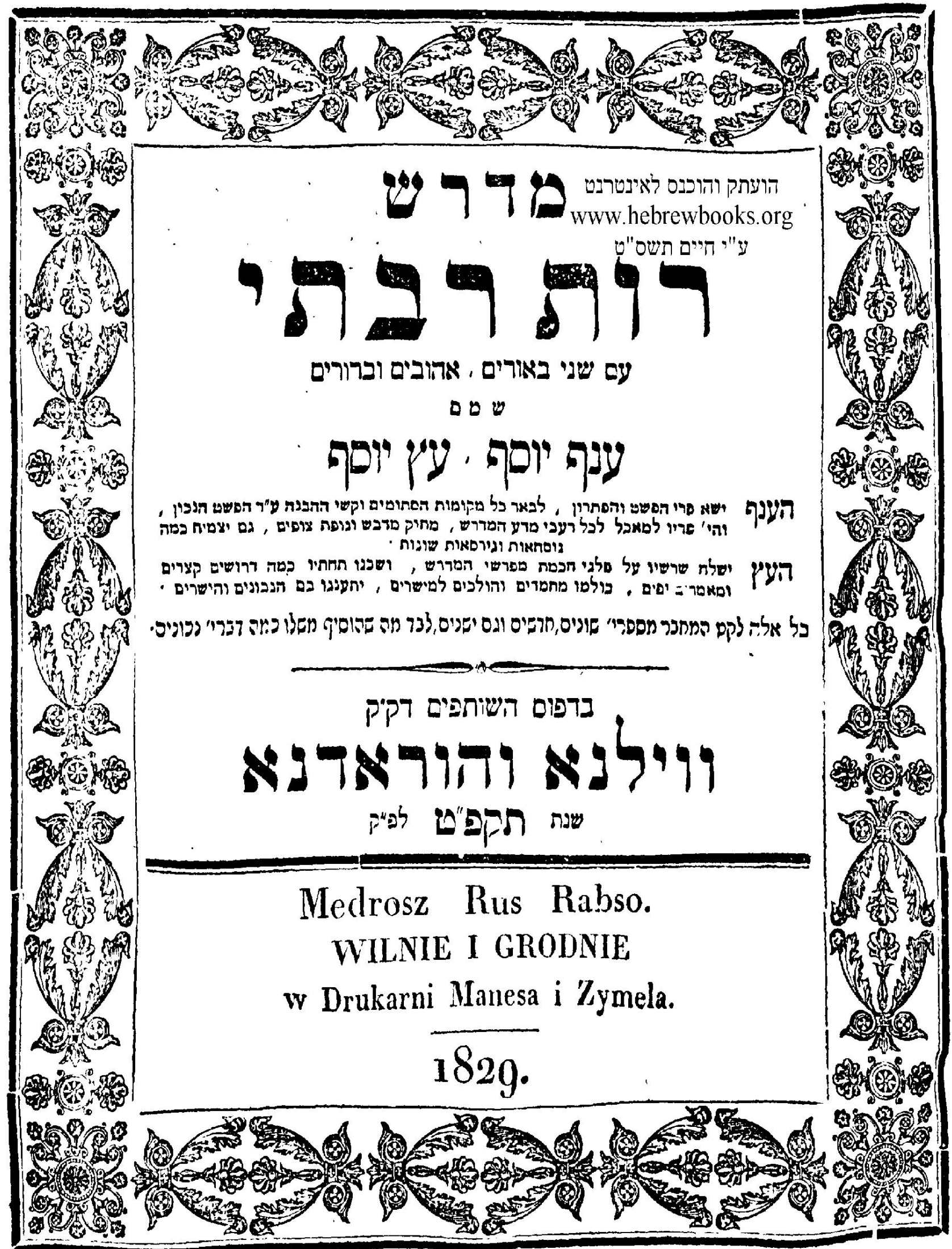




\section{מדרעש רות רבה}

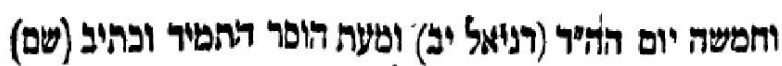

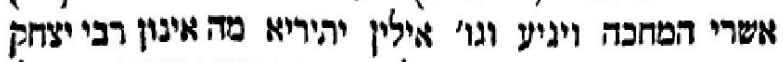

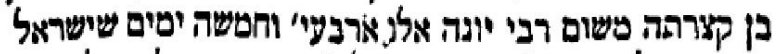

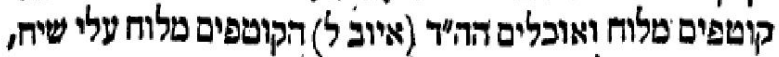

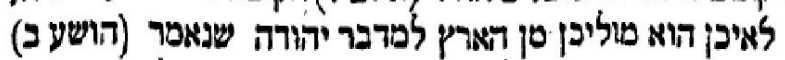

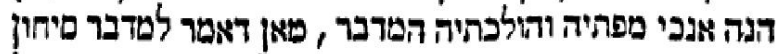

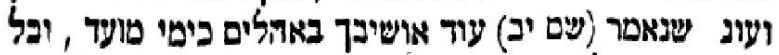

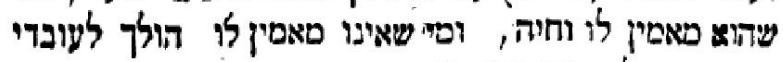

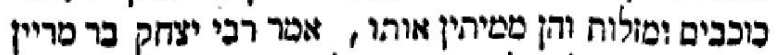

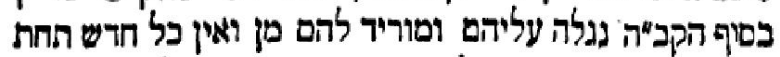

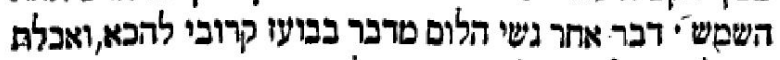

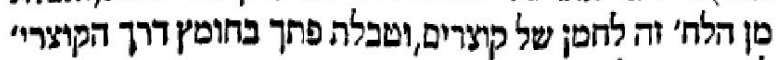

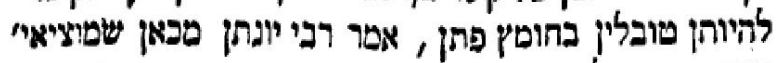

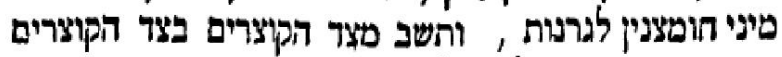

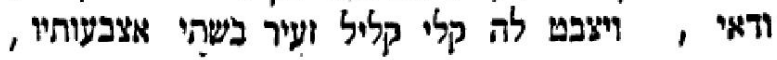

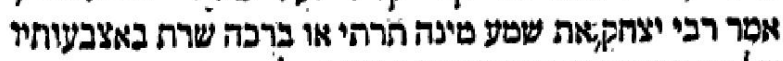

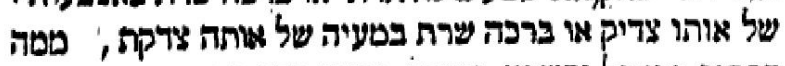

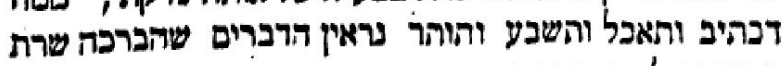

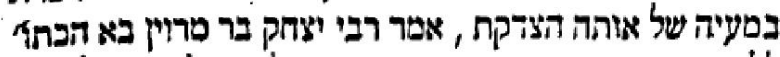

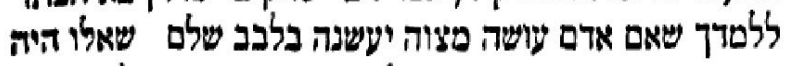

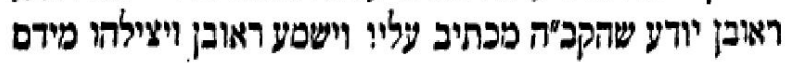
כבתטו

\section{קy}

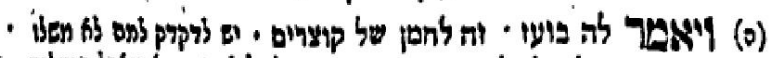

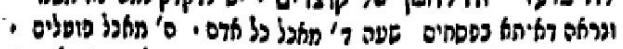

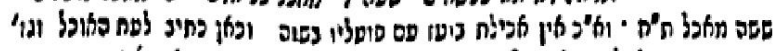

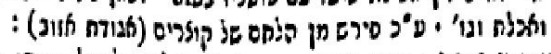

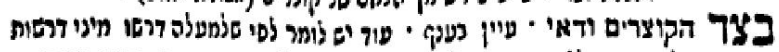

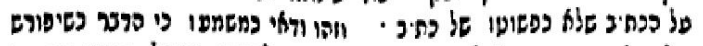

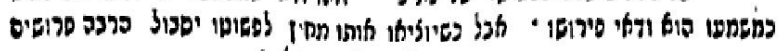
:

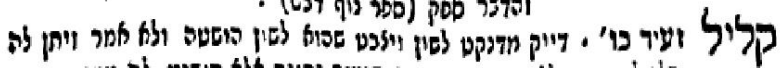

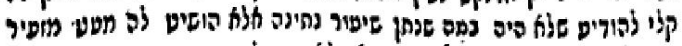

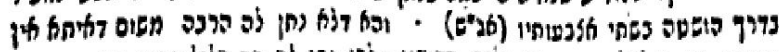

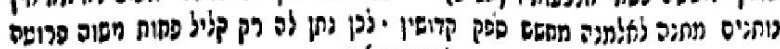
$:(0.595)$

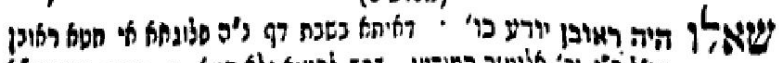

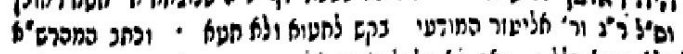

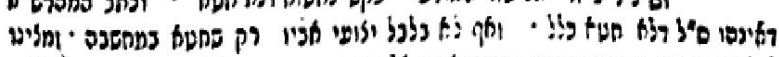

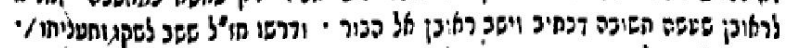

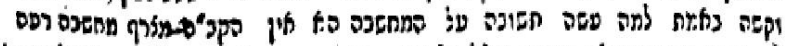

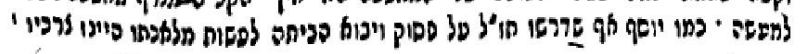
ov

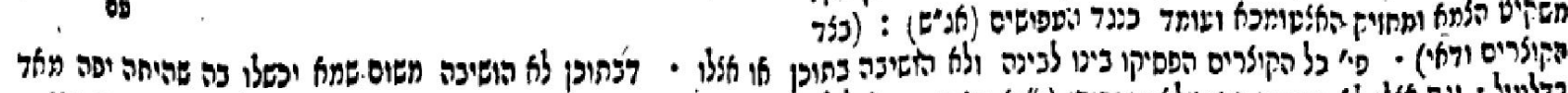

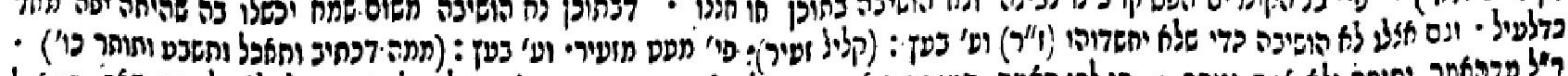

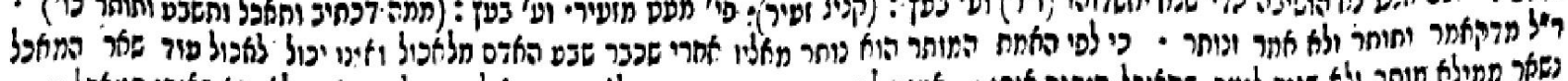

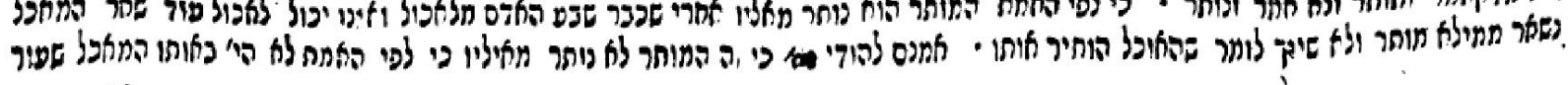

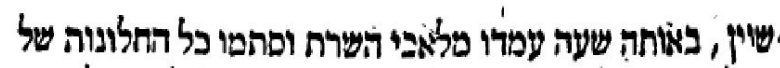

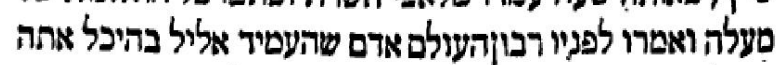

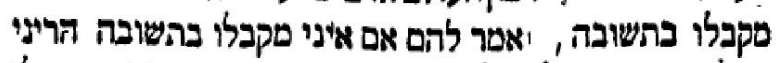

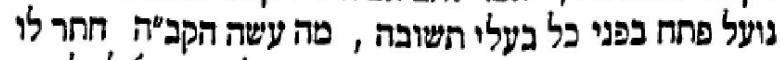

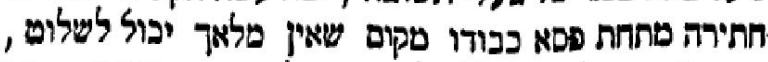

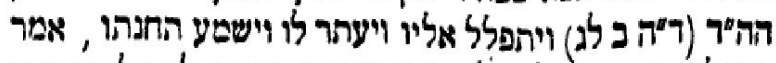

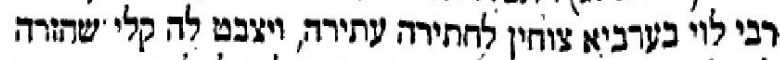

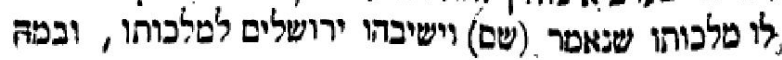

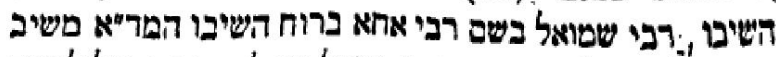

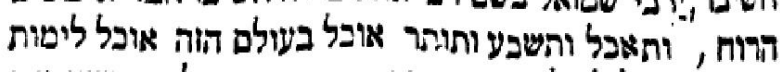

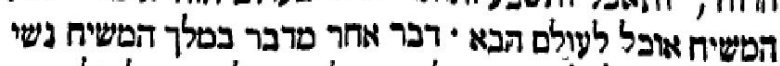

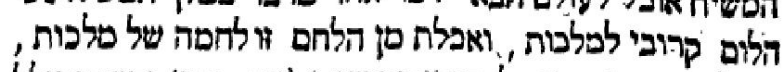

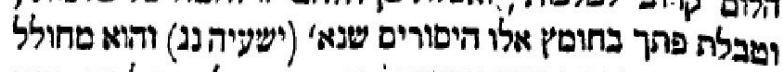

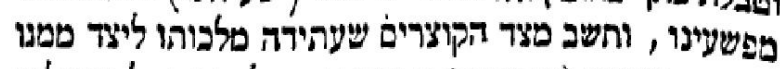

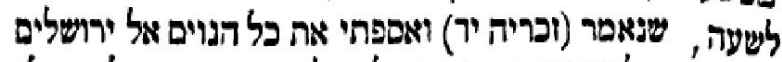

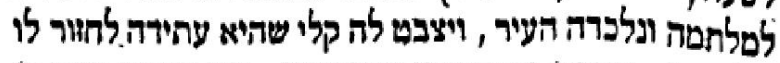

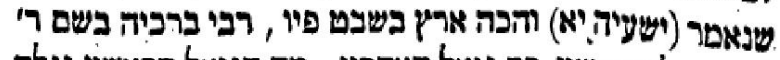

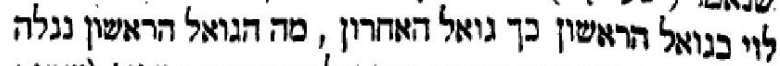

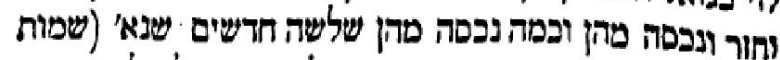

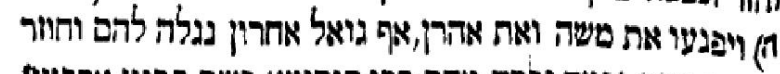

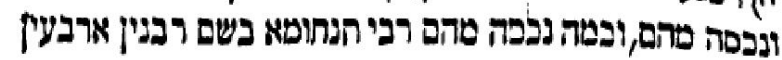

\section{ply}

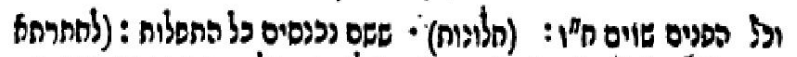

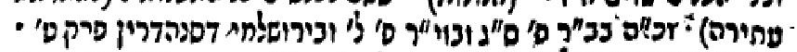

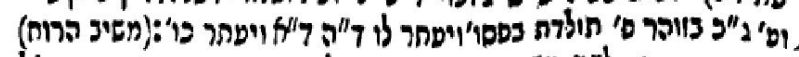

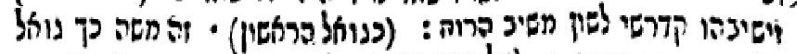

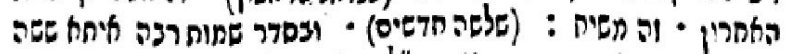

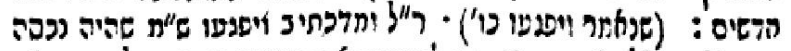

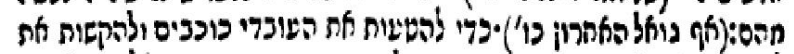

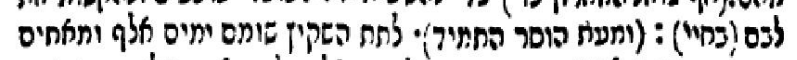

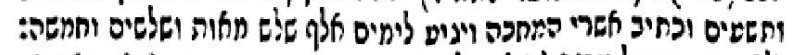

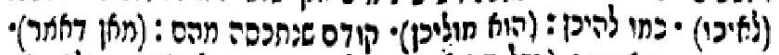

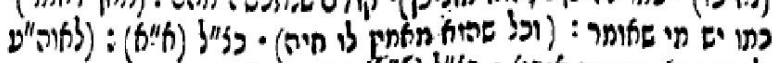

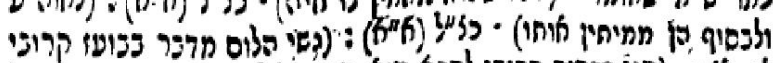

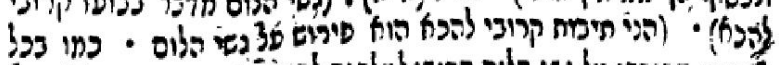

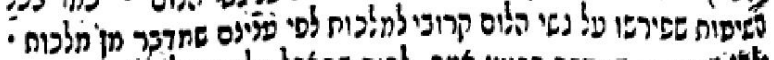

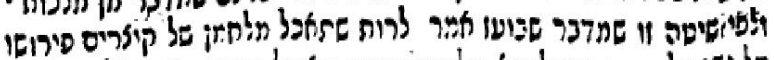

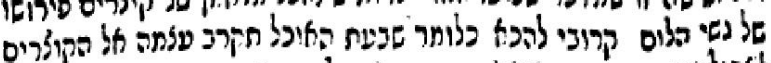

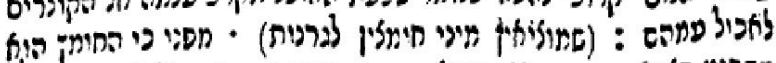

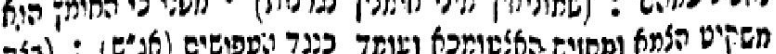
נירו 
ANEXO B

PÁGINA DO MIKRAOTH GEDOLOTH CONTENDO O TEXTO E AS INTERPRETAÇÕES DE ISAÍAS 52.13-53.12 


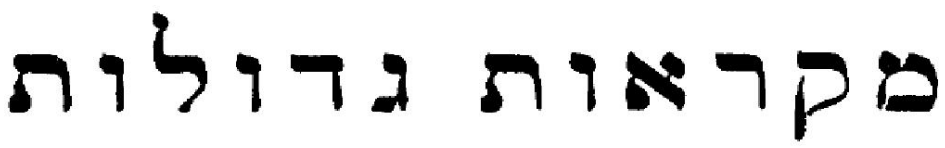 \\ רס
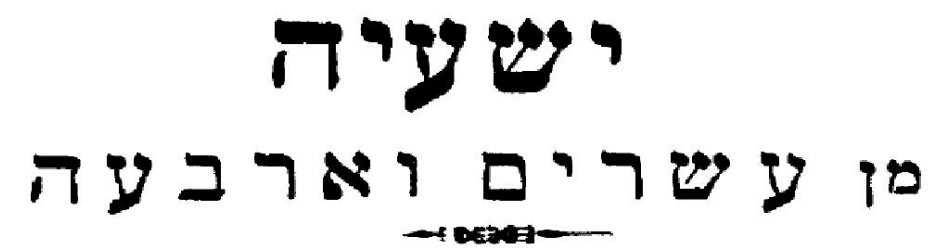

באותיות גדוSות , ובכל פאר ויופי אשר עוד לא היה לעולטים

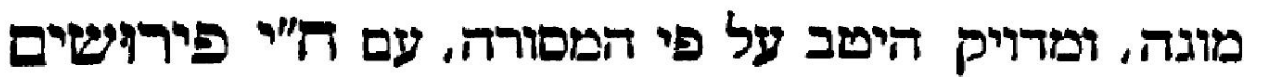

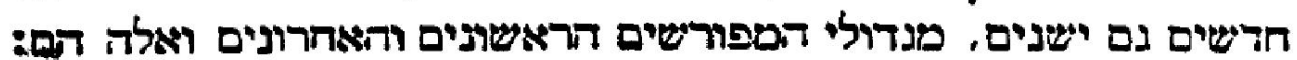

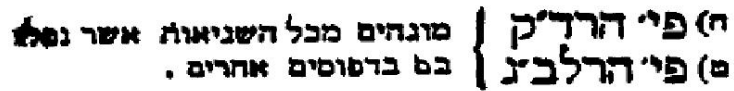

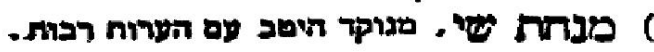

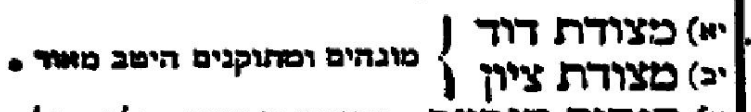

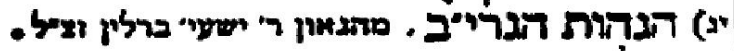

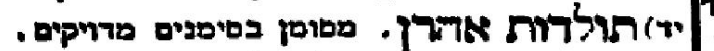

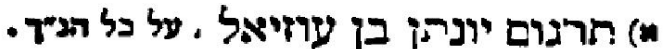

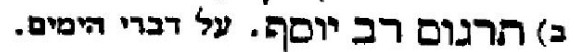

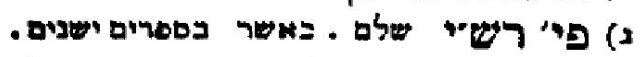

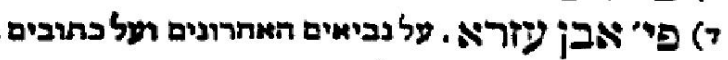

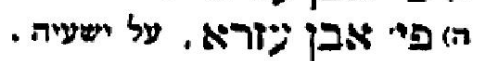

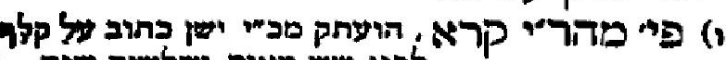

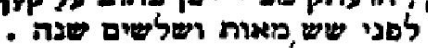

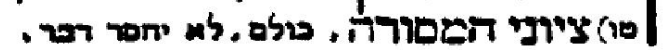
ום ביי רבינו כעדיה גאון , על דניאל .

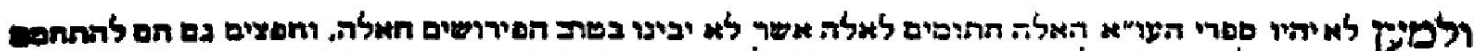

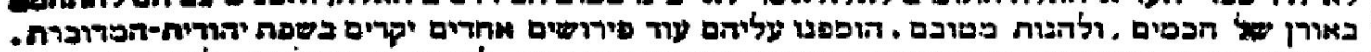

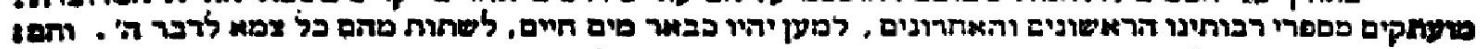

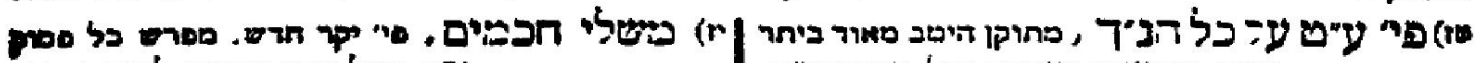

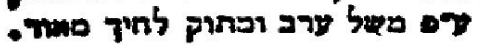

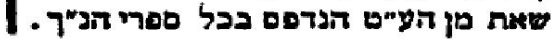

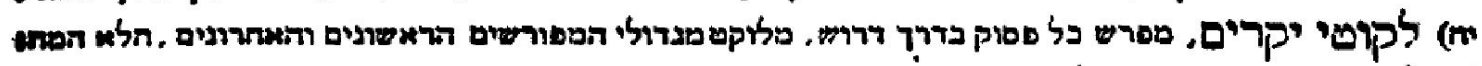

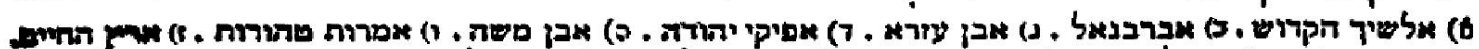

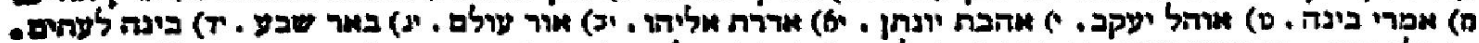

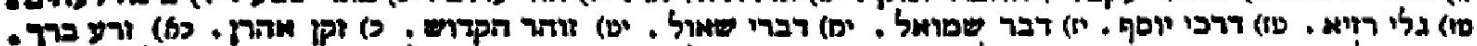

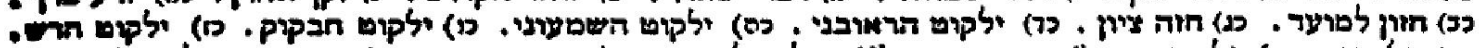

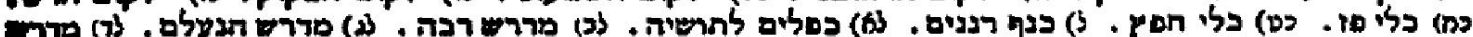

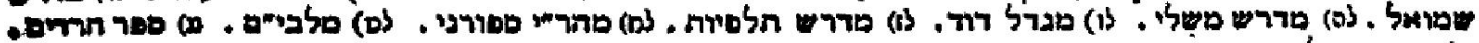

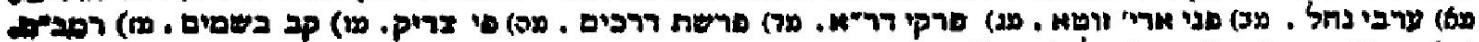

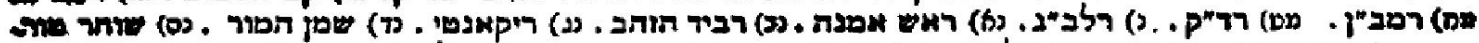

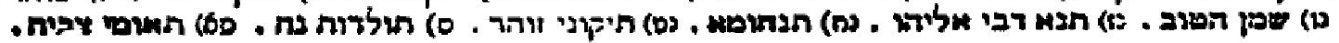

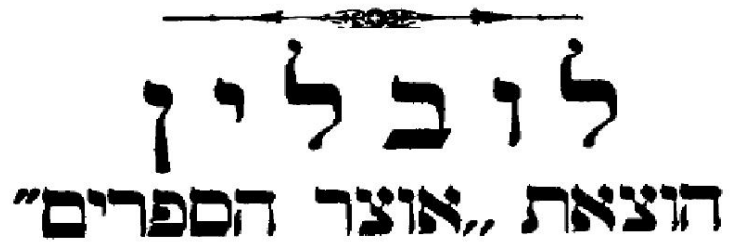

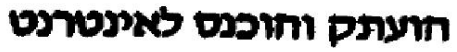 \\ www.hebrewbooks.org \\ "'pus am s"y
}


ריגום

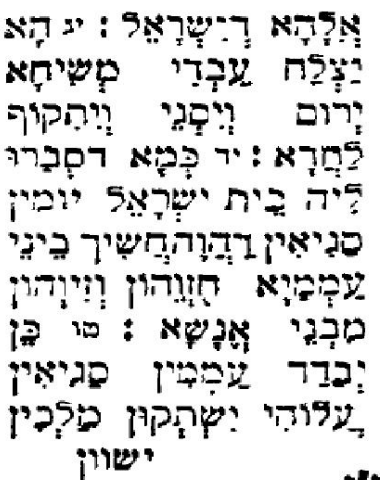

\section{צשר}

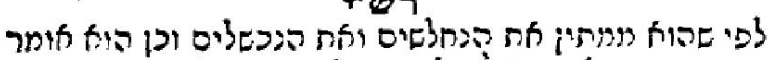

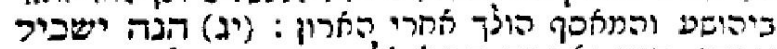

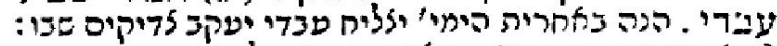

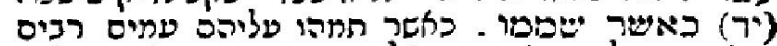

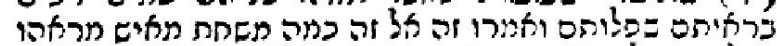
(5)

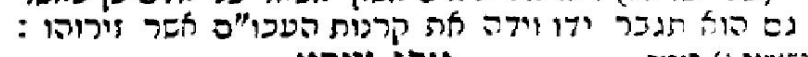

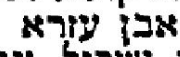

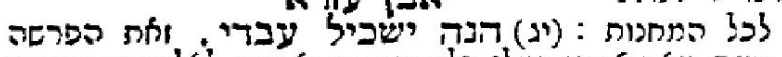

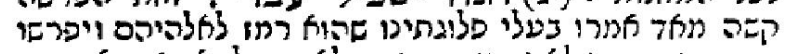

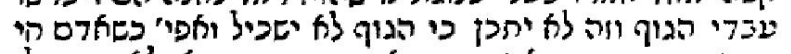

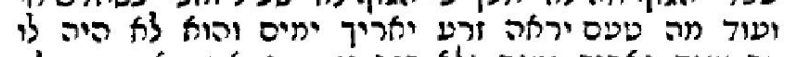

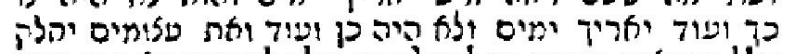

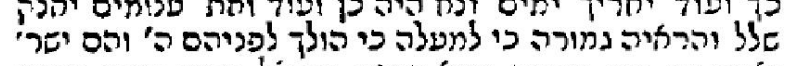

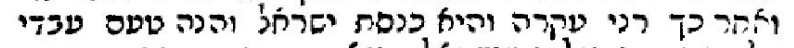

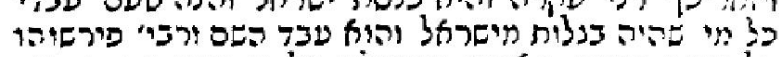

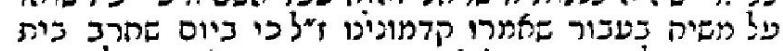

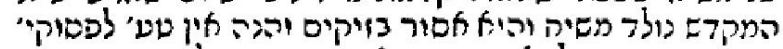

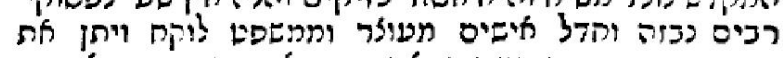

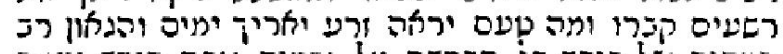

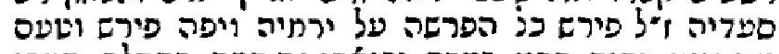

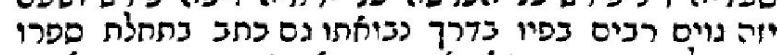

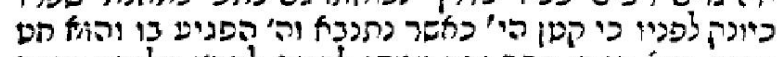

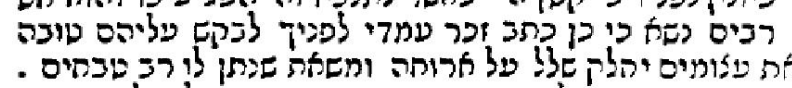

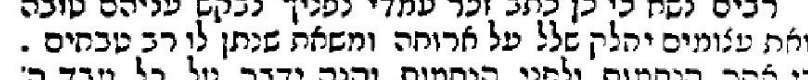

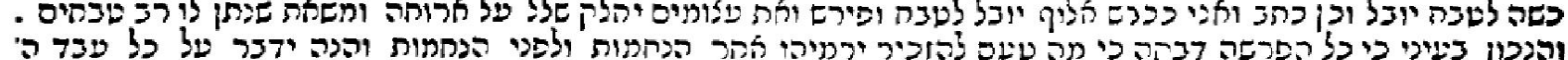

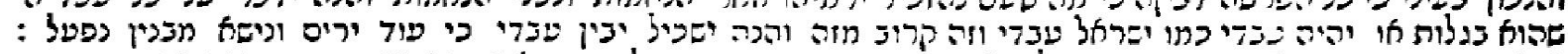

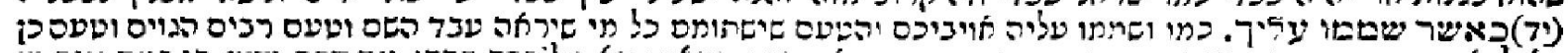

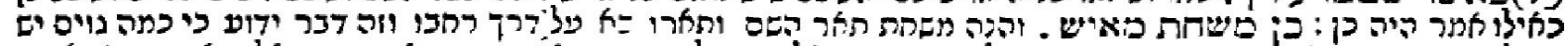

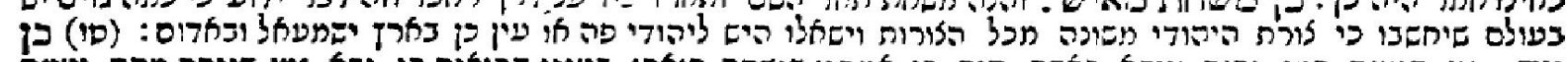

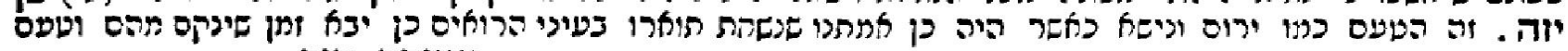

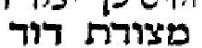

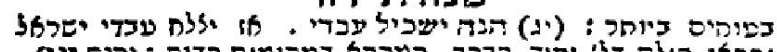

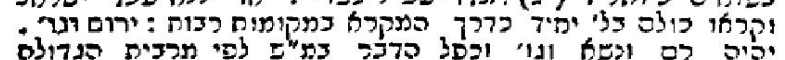
ו

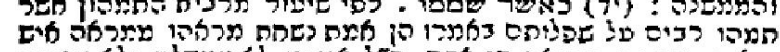

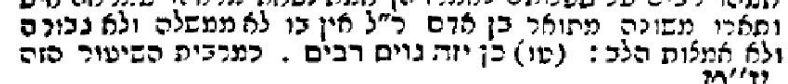

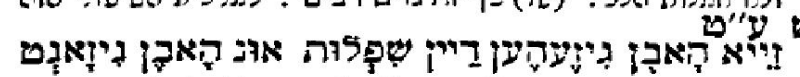

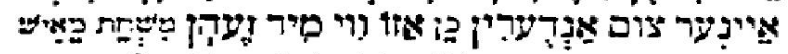

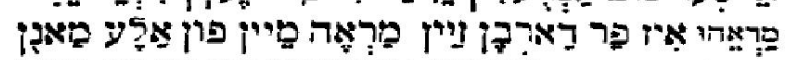

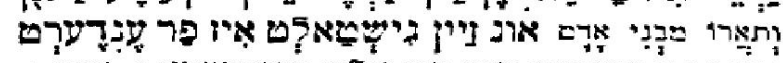

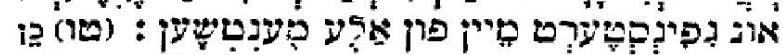

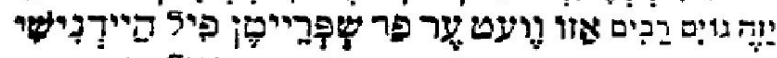
วรyอ
ביטים

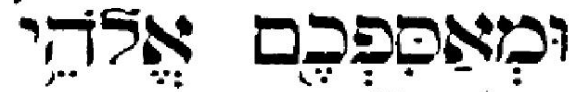

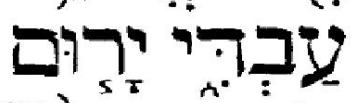
-

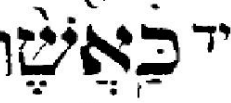

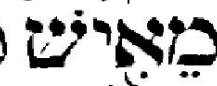

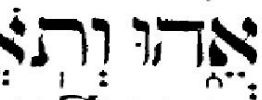
קר

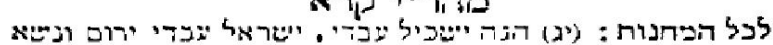

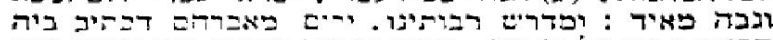

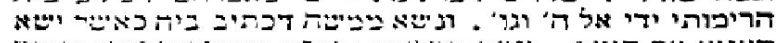

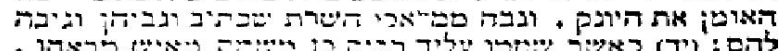

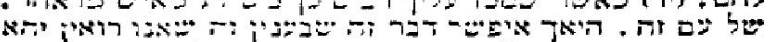

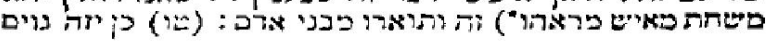

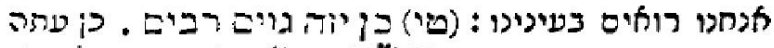

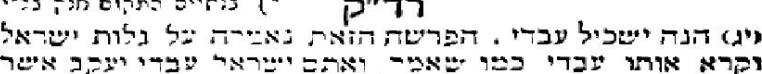

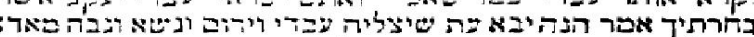

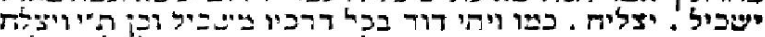

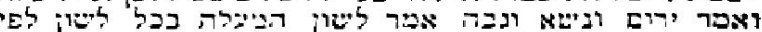

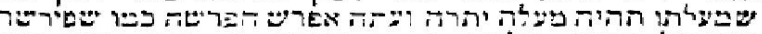

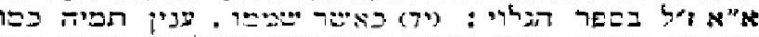

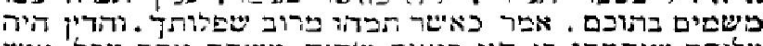

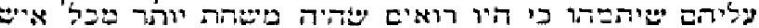

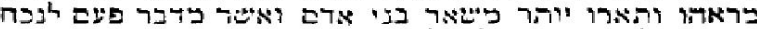

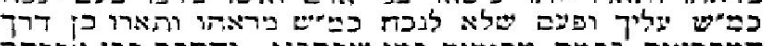

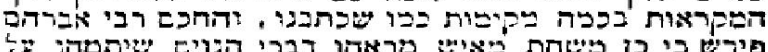

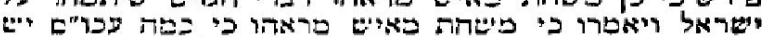

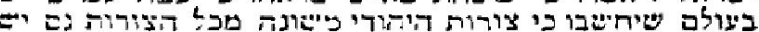

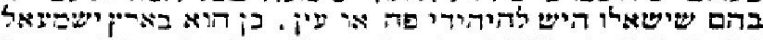

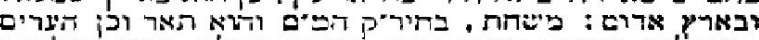

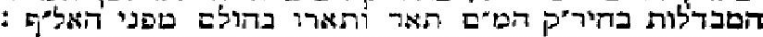

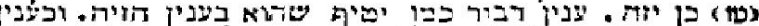

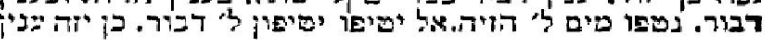

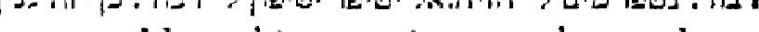

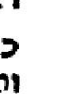

(1)

241 


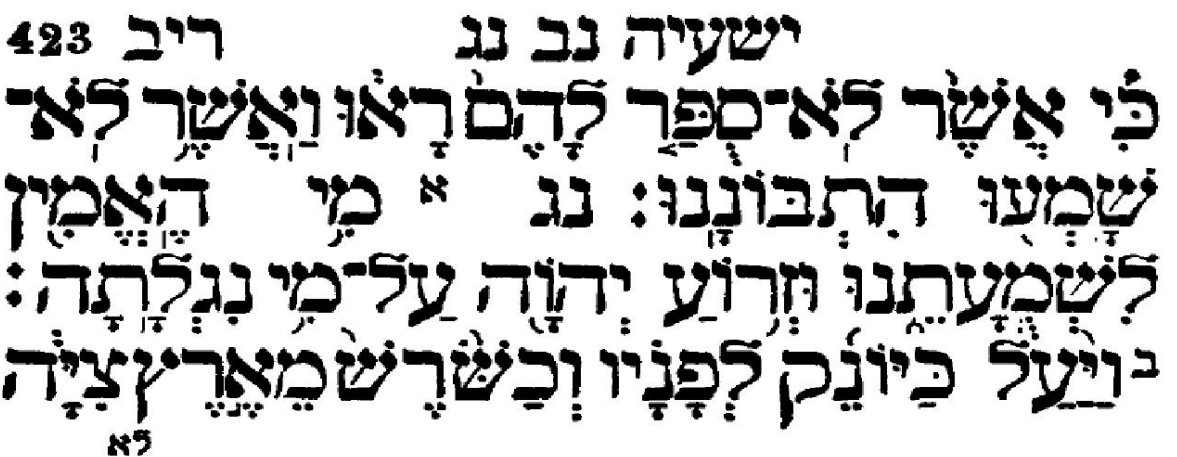

\section{תרגום}

ן טים

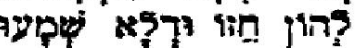

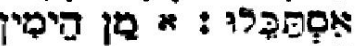

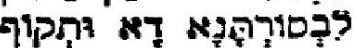

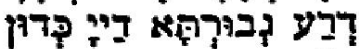
: "

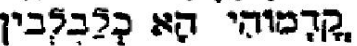

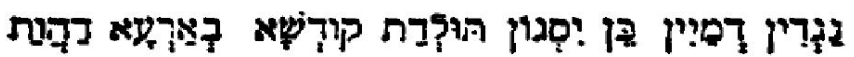

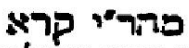

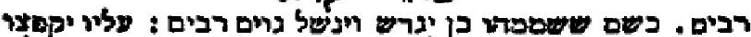

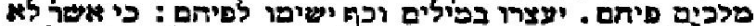

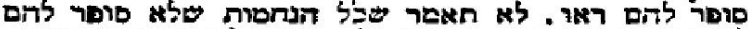

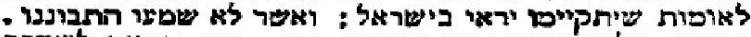

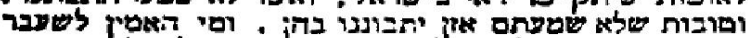

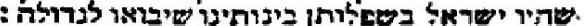

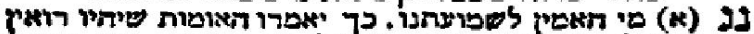

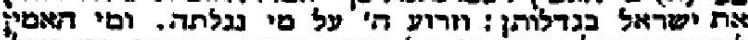

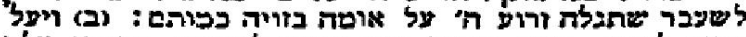

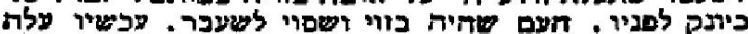

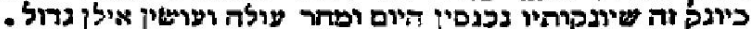

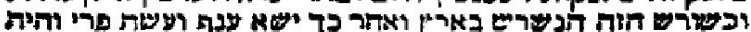

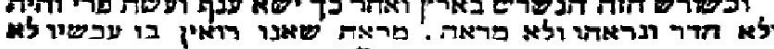

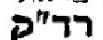

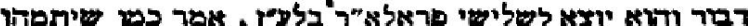

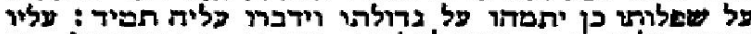
וקםצו טלכים טיהם. אטי" לםלכים יראח כבודם כבור גרול . וכן

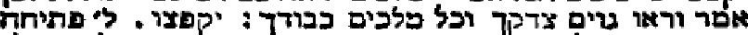

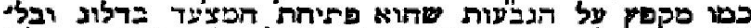

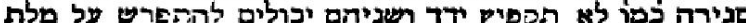

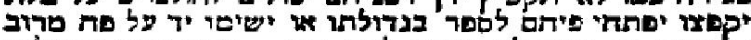

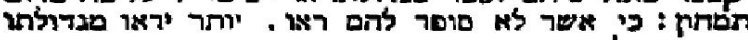

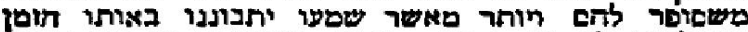

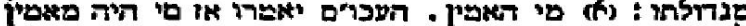

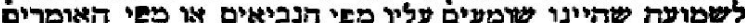

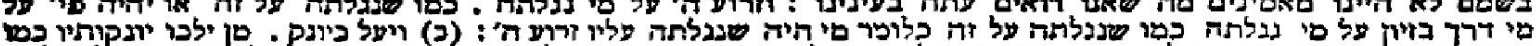

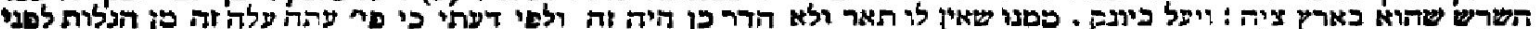

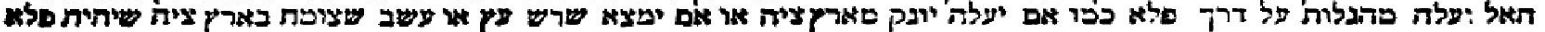

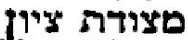

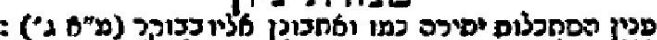

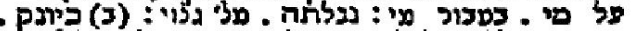

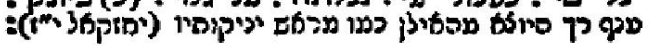

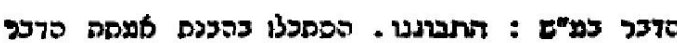

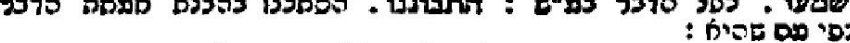

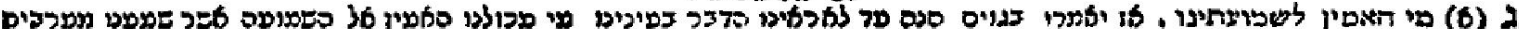

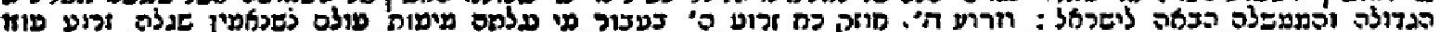

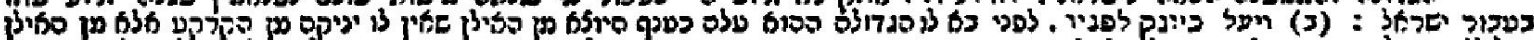

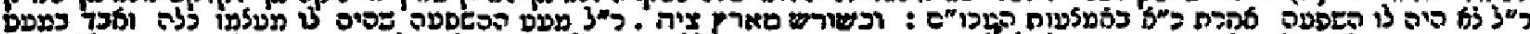

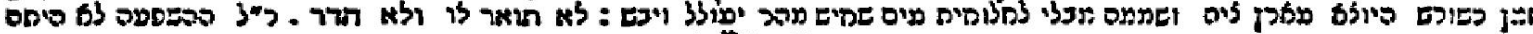

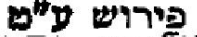

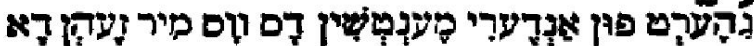
נ4x

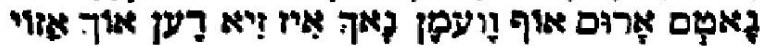

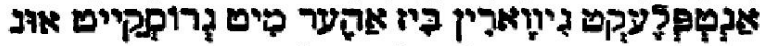

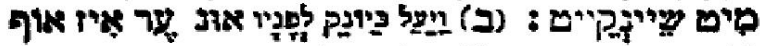

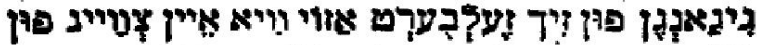

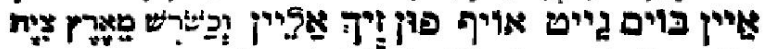

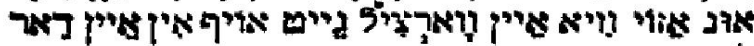

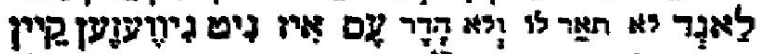

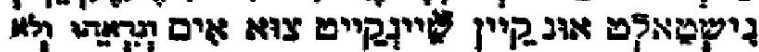
nith

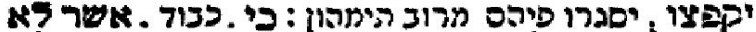

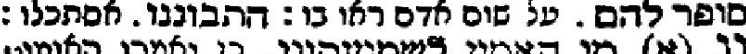

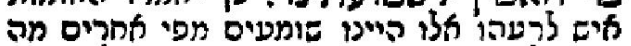

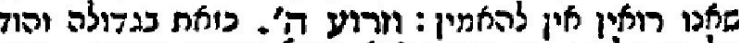

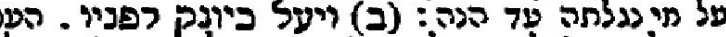

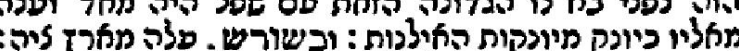

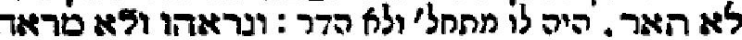
ארז

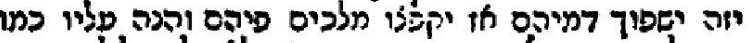
:

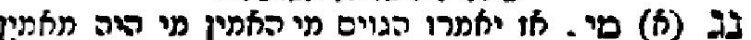

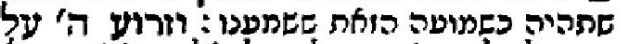

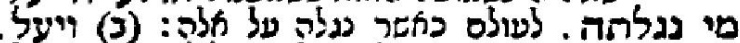

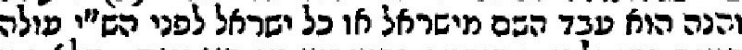

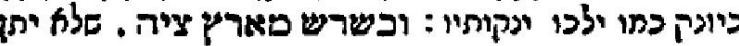
טצורח דוד

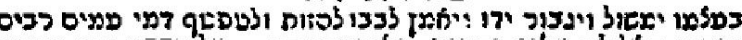

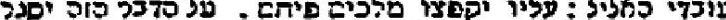

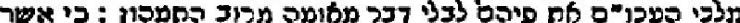

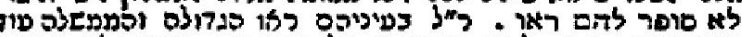

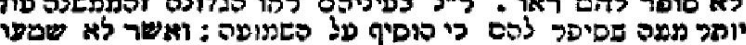

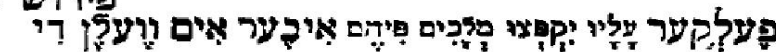

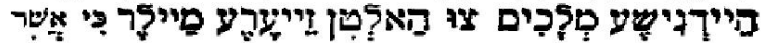
רא

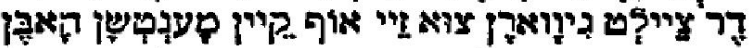

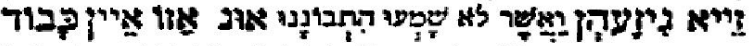

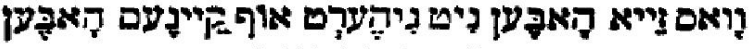
:

ם צ' 23

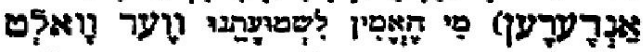

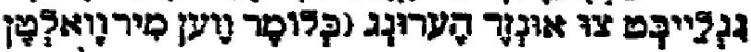


מח

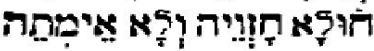

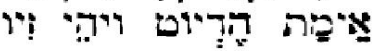

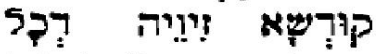

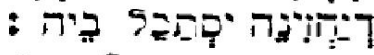

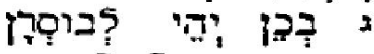

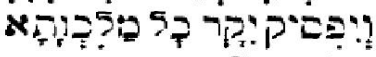

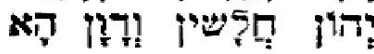

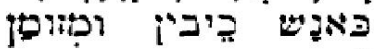

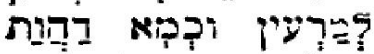
בער

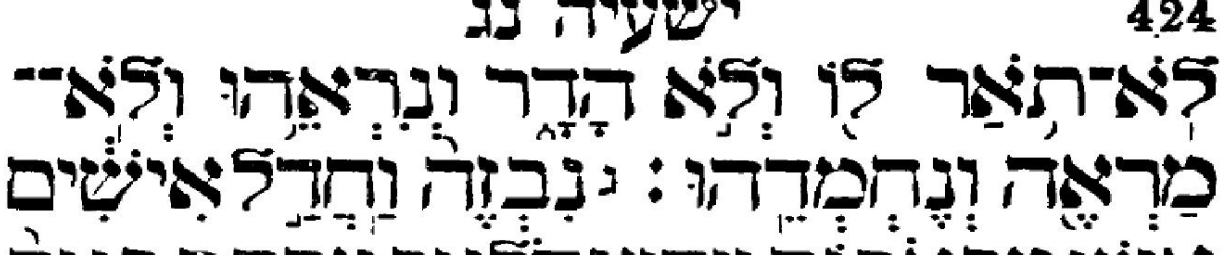

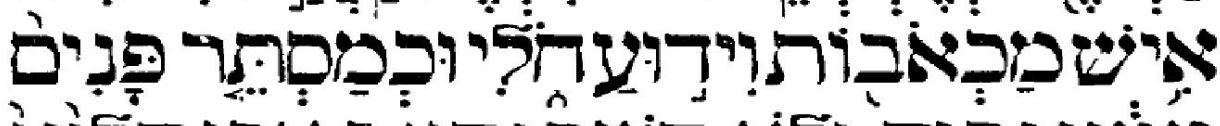

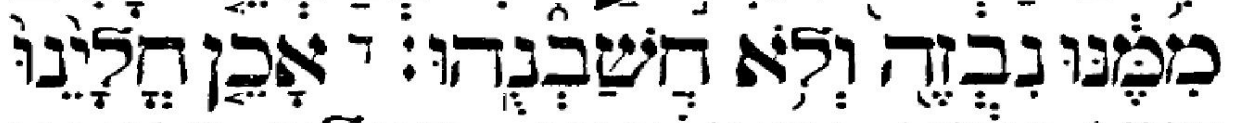

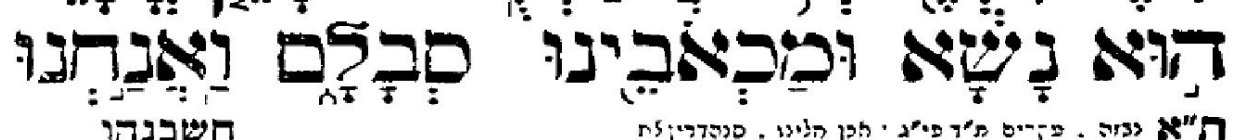

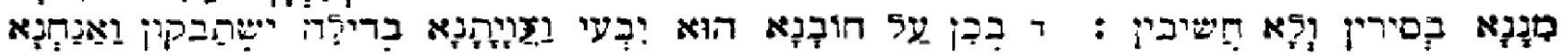

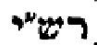

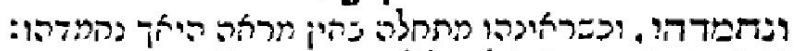

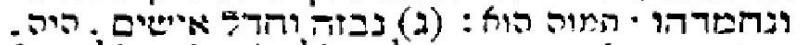

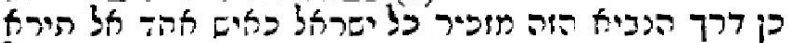

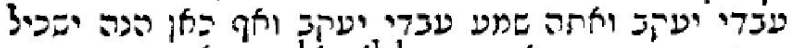

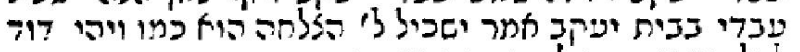

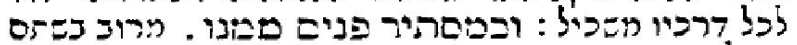
"

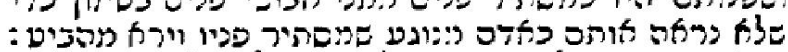

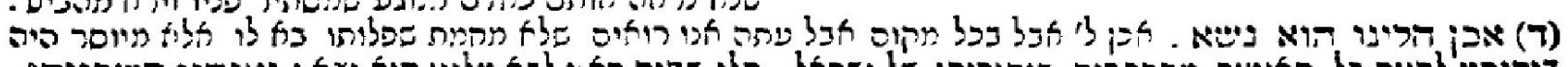

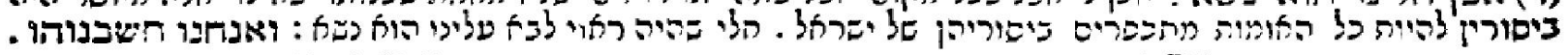

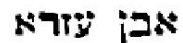

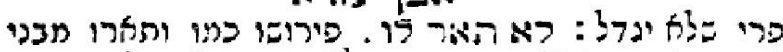

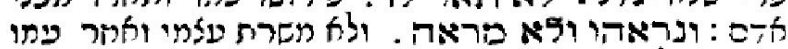
;

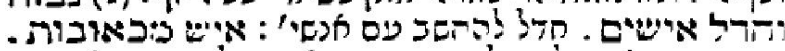

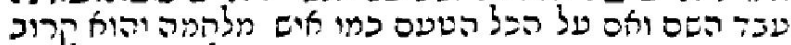

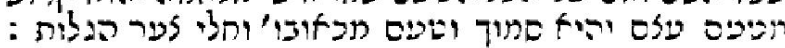
1

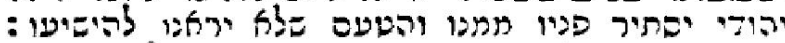

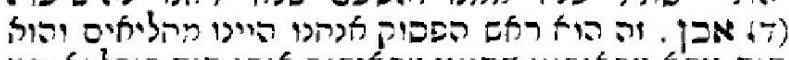

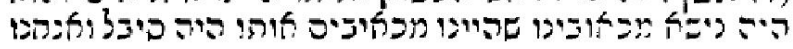

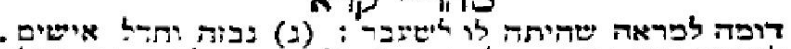

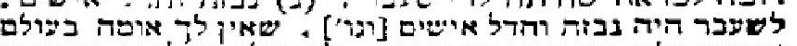

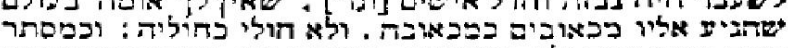

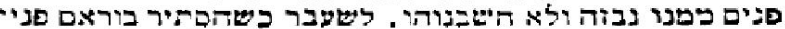

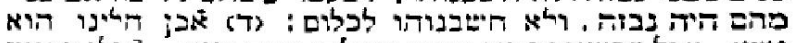

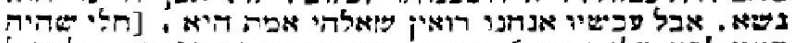

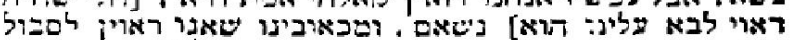

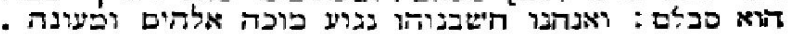

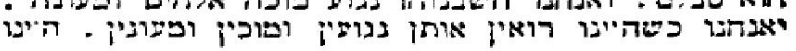

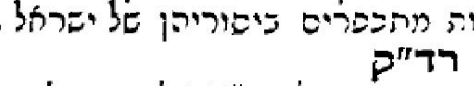

כן היח שלא עלותט פהגלות והקנין כשיל בט"ש : לא תאר לו .

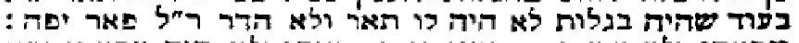

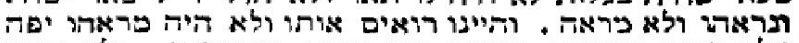

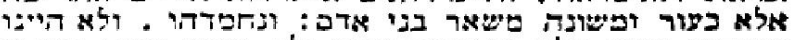

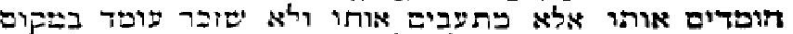

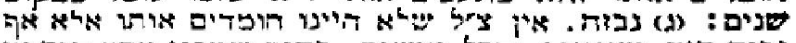

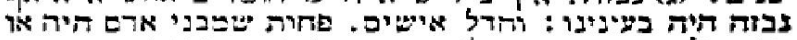

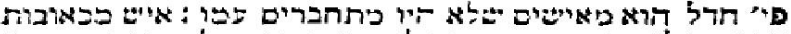

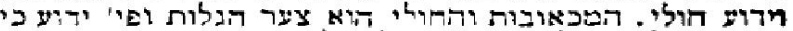

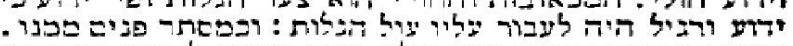

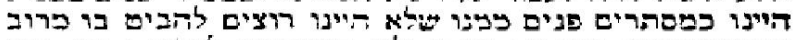

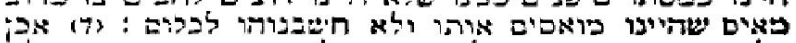

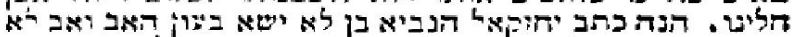

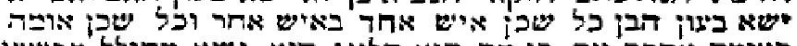

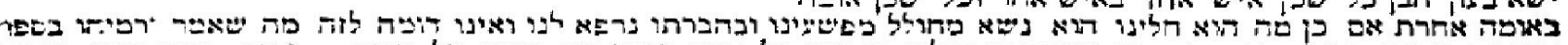

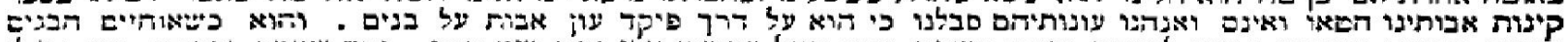

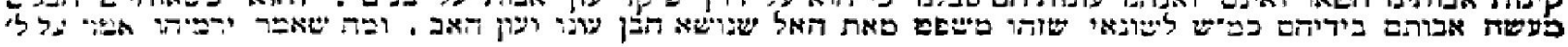

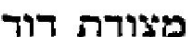

D)

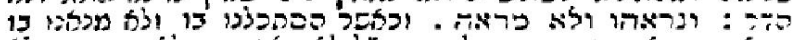

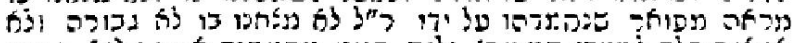

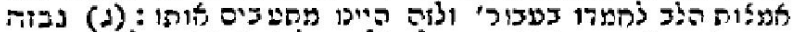

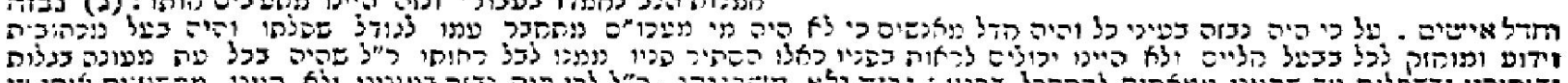

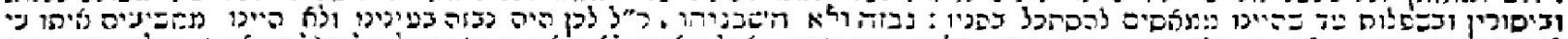

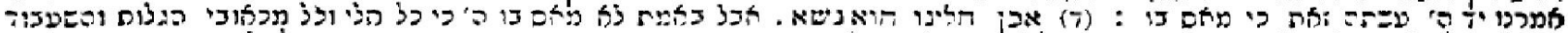

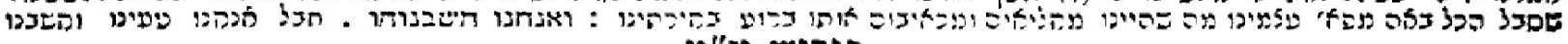

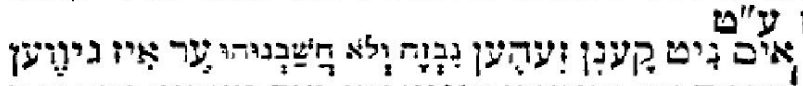

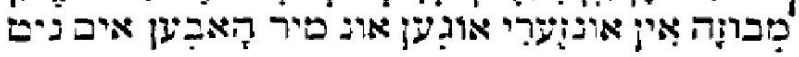

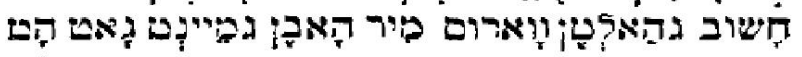

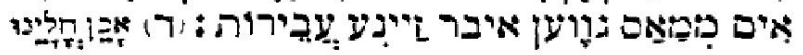

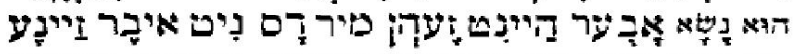

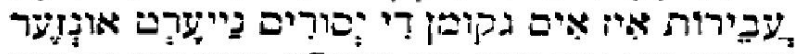

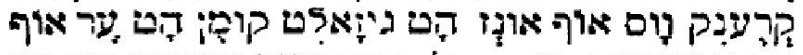

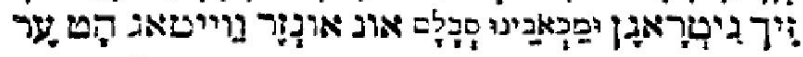
דוב

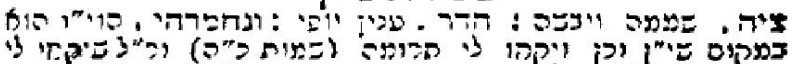

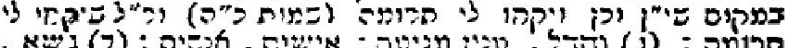
פירוטים

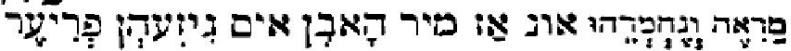

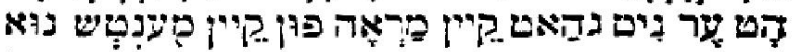

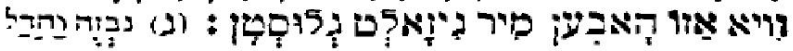

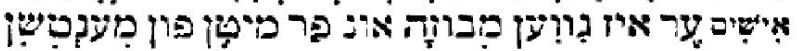

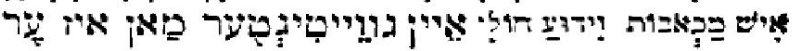

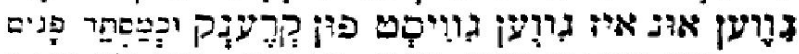

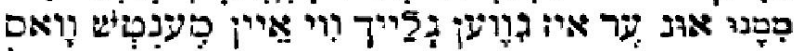

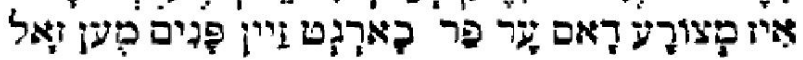




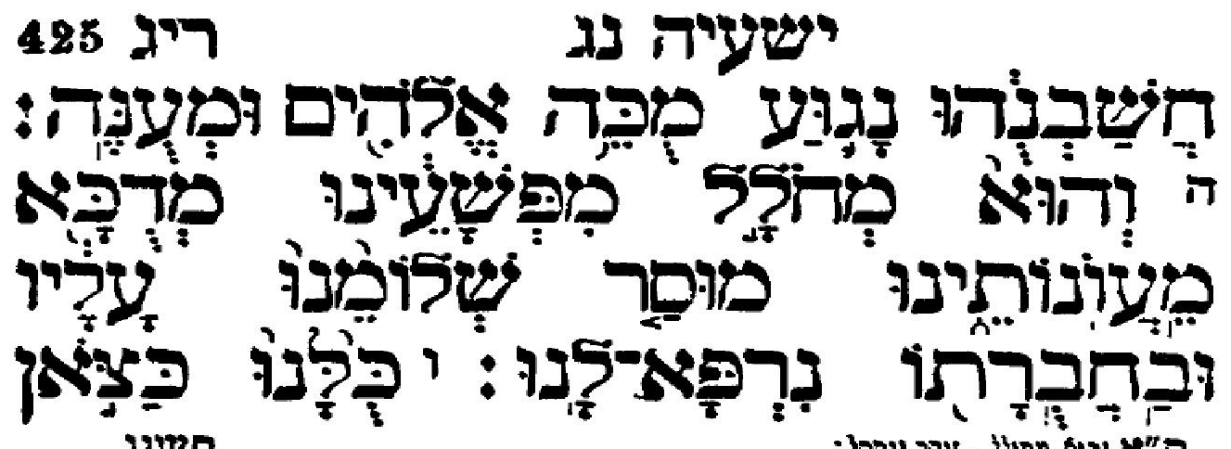

xרק ing

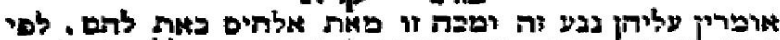
- שאין ביו

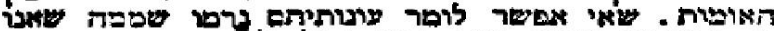

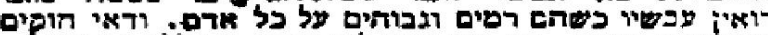

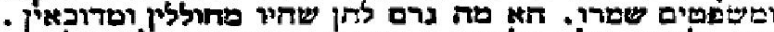

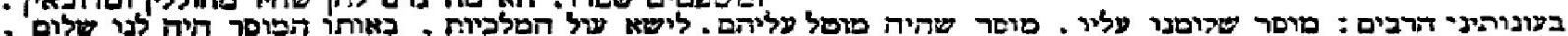

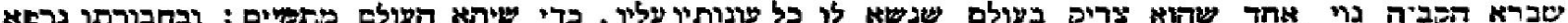

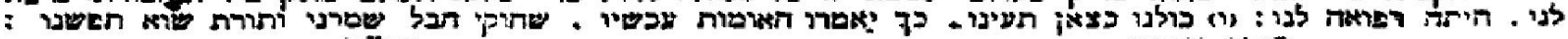
רדומה

*⿻一𠃋

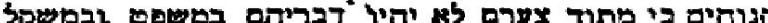

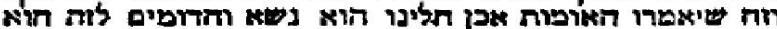

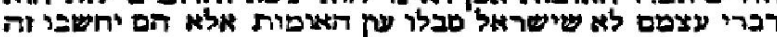

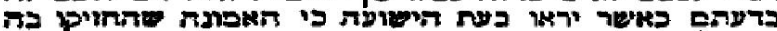

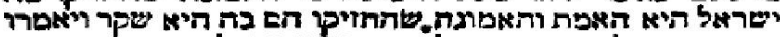

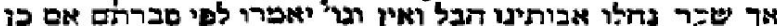
כיה היה הצער-שהיו סובכים ישראל כנלות הנה לא היה בעונם

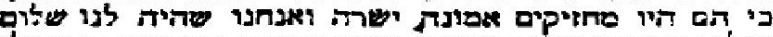

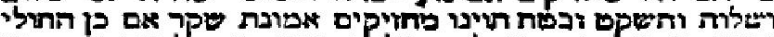

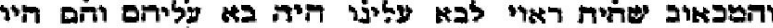

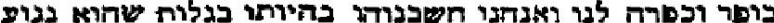

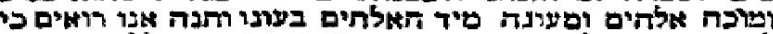

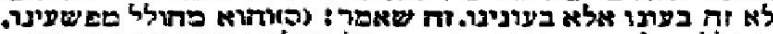

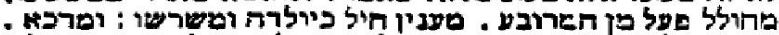

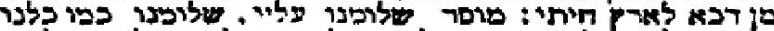

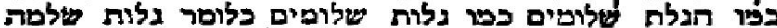

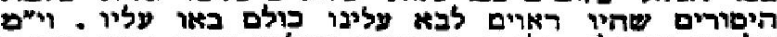

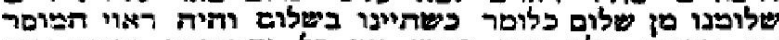

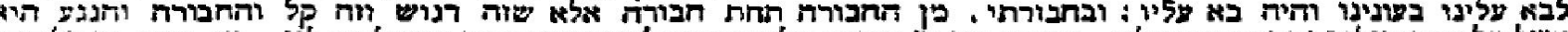

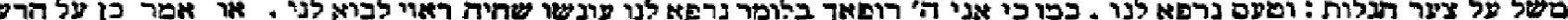

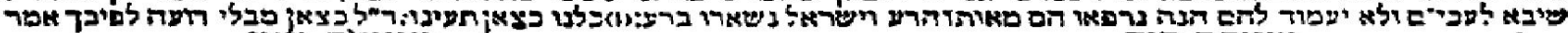

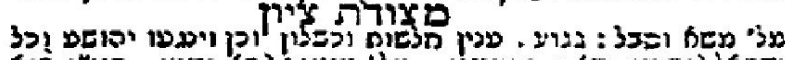

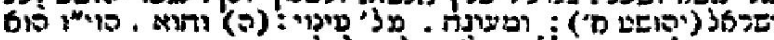

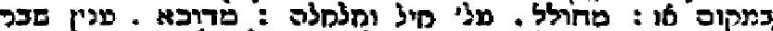

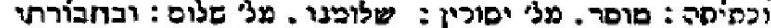

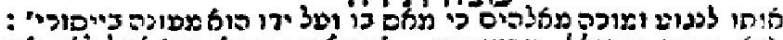
ה

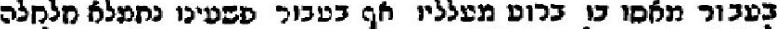

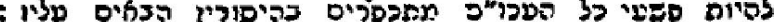
טיו

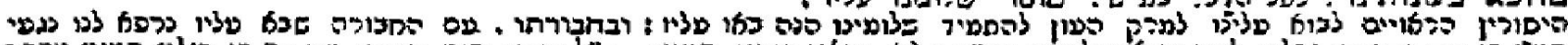

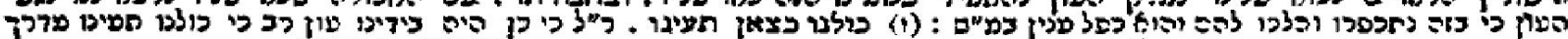
מים

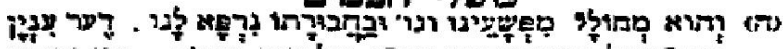

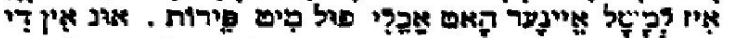

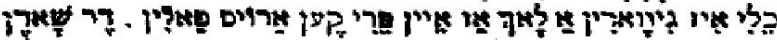

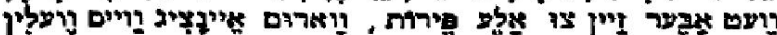

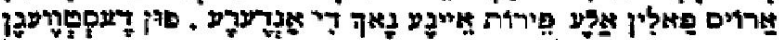
ל

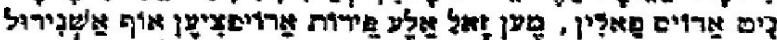
20.

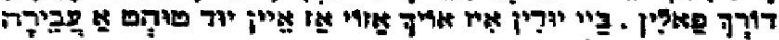

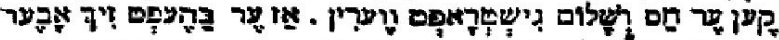

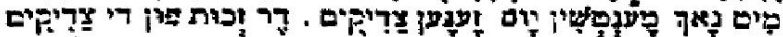

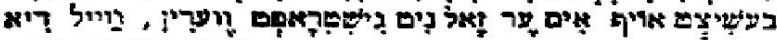

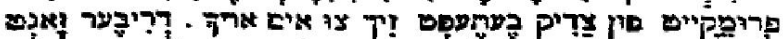

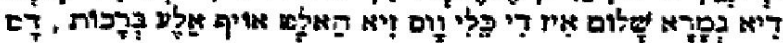

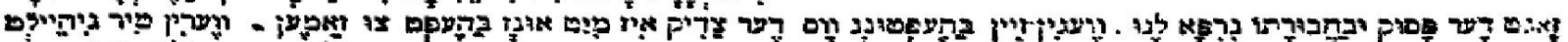

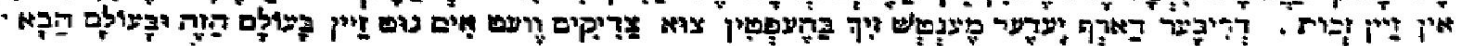

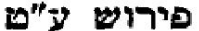

גוא

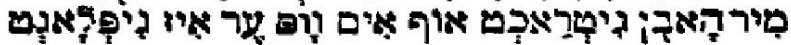

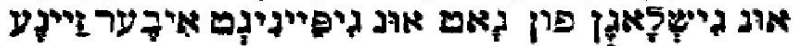

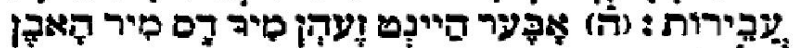

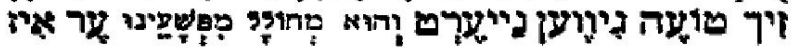

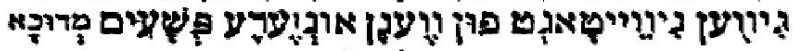

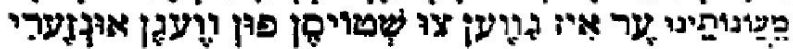

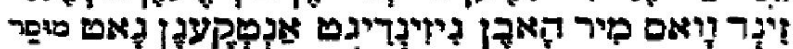

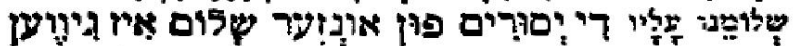

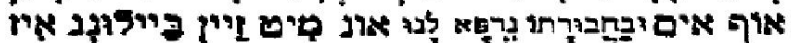

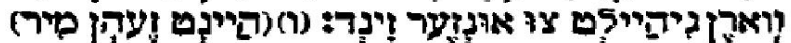


רתרגום

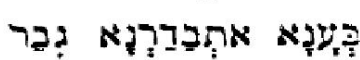

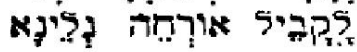

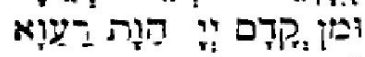

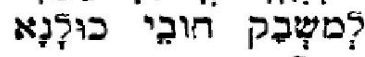

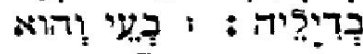
חתפ

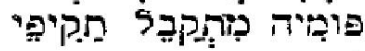
א אรา

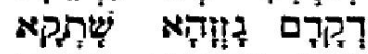

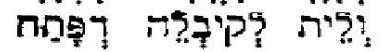

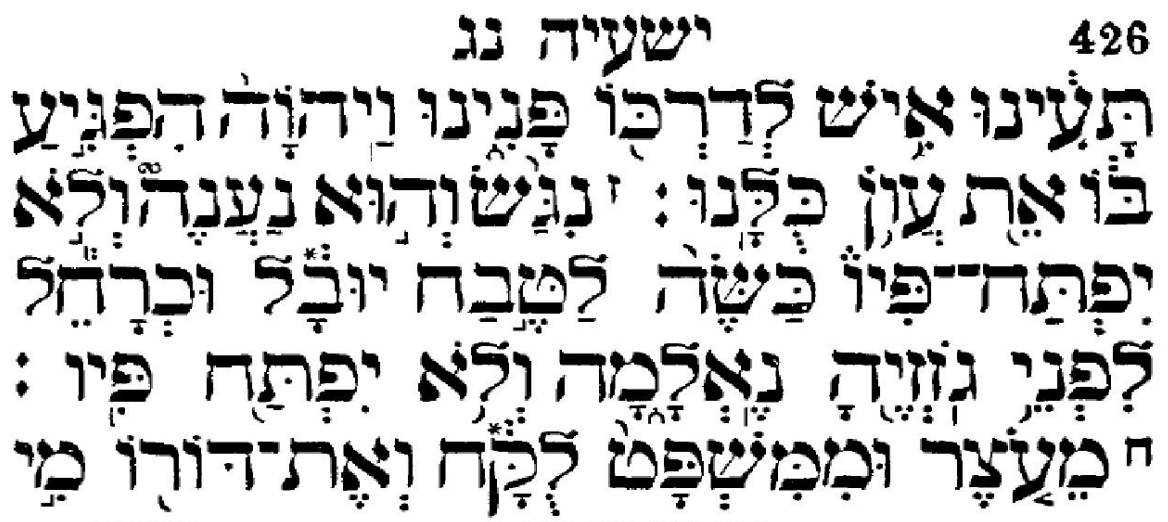

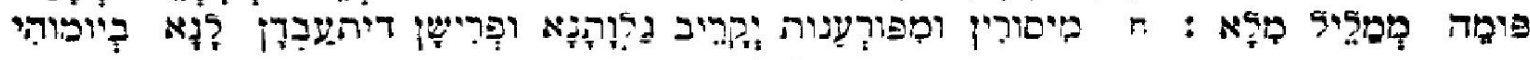

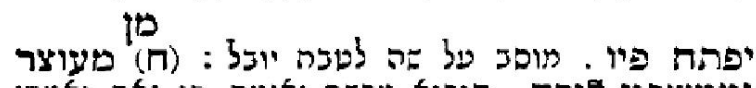

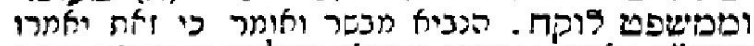

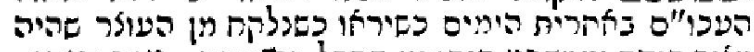

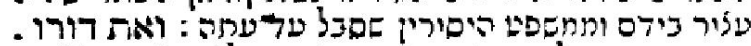

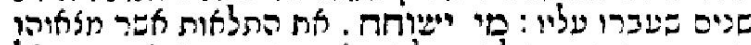

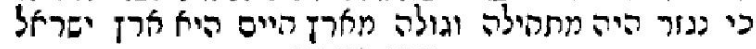

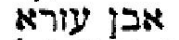

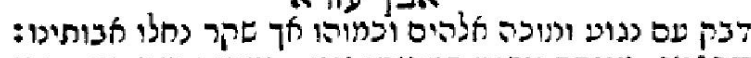

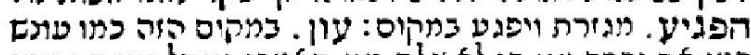

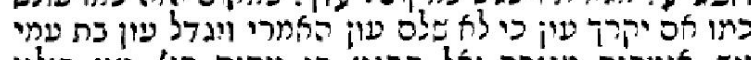

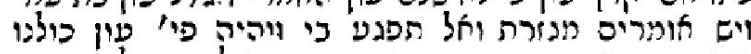

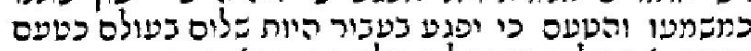

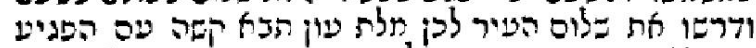

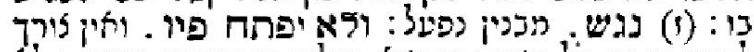

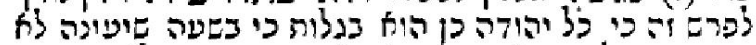

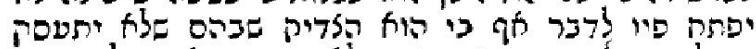

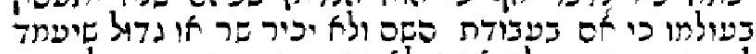
ל

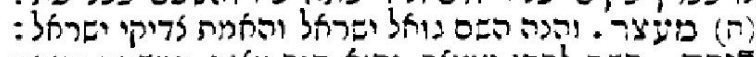

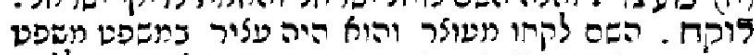

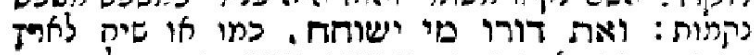

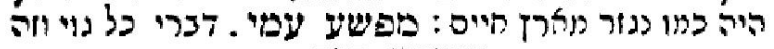
טצורת דפור

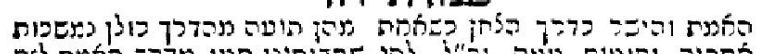
ה

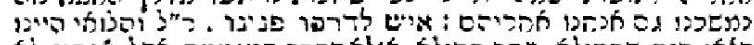
a) 年1

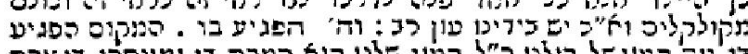

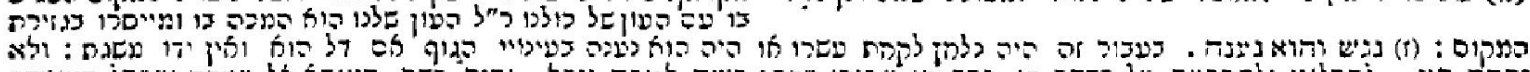
"שר

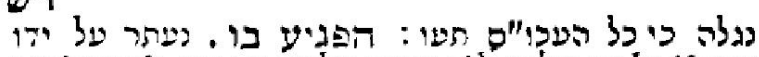

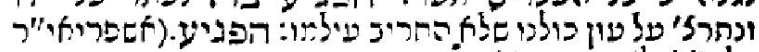

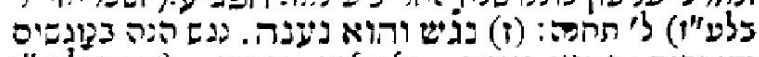

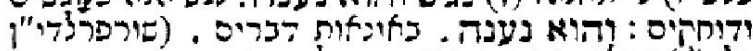

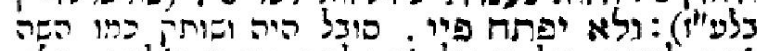

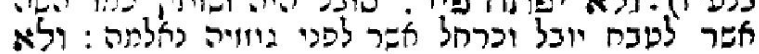
רד

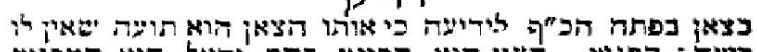

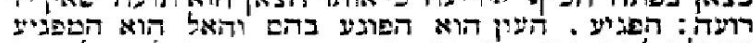

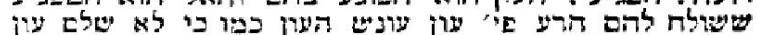

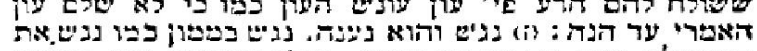

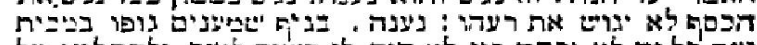

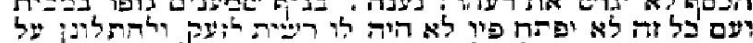

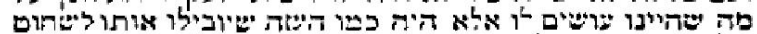

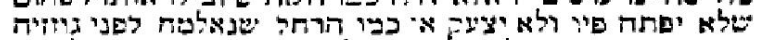

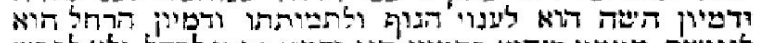

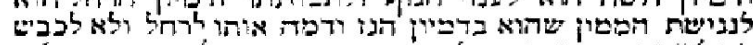

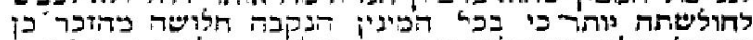

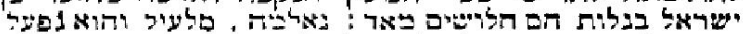

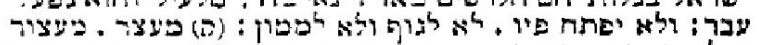

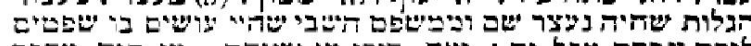

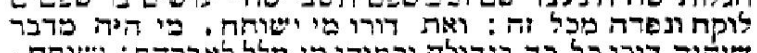

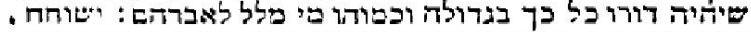

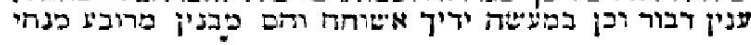

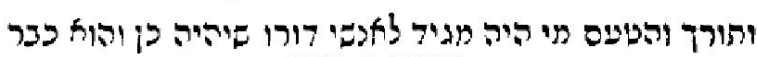

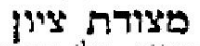

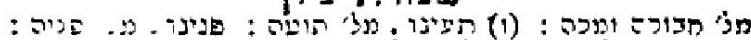

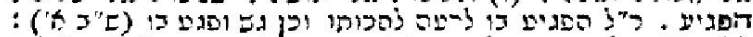

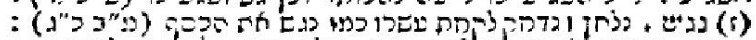

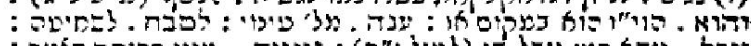

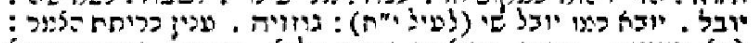

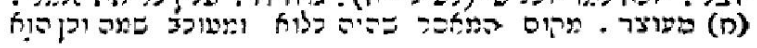

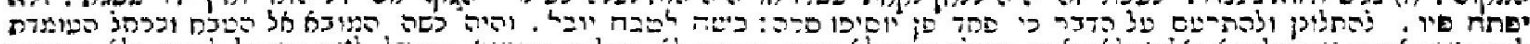
של

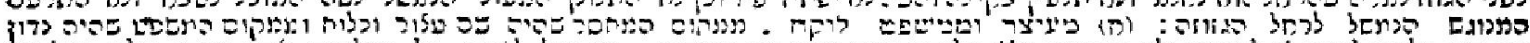

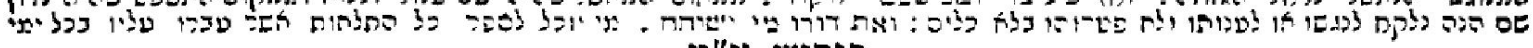

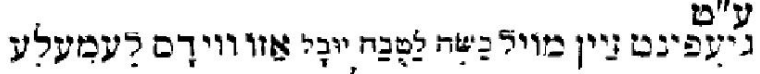
אים

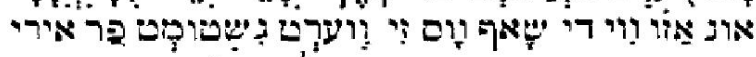

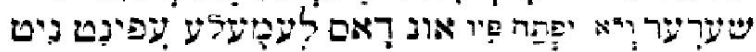

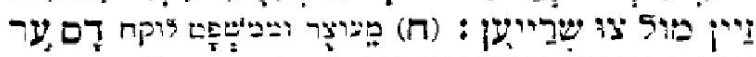

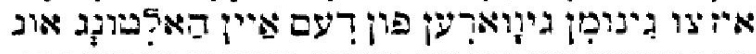

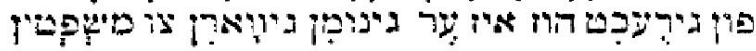

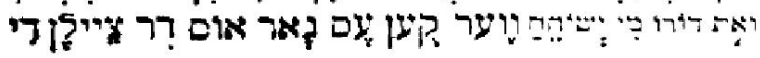
ת

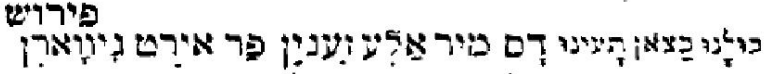

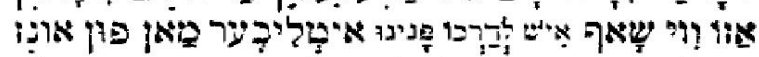

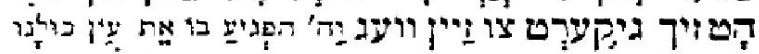

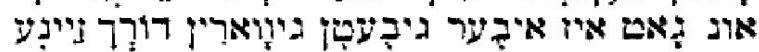

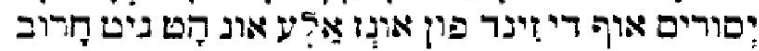

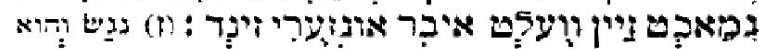

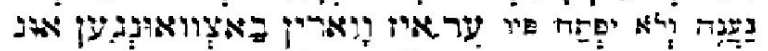

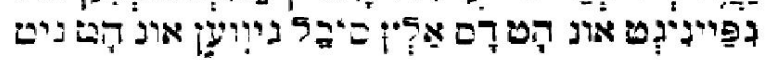




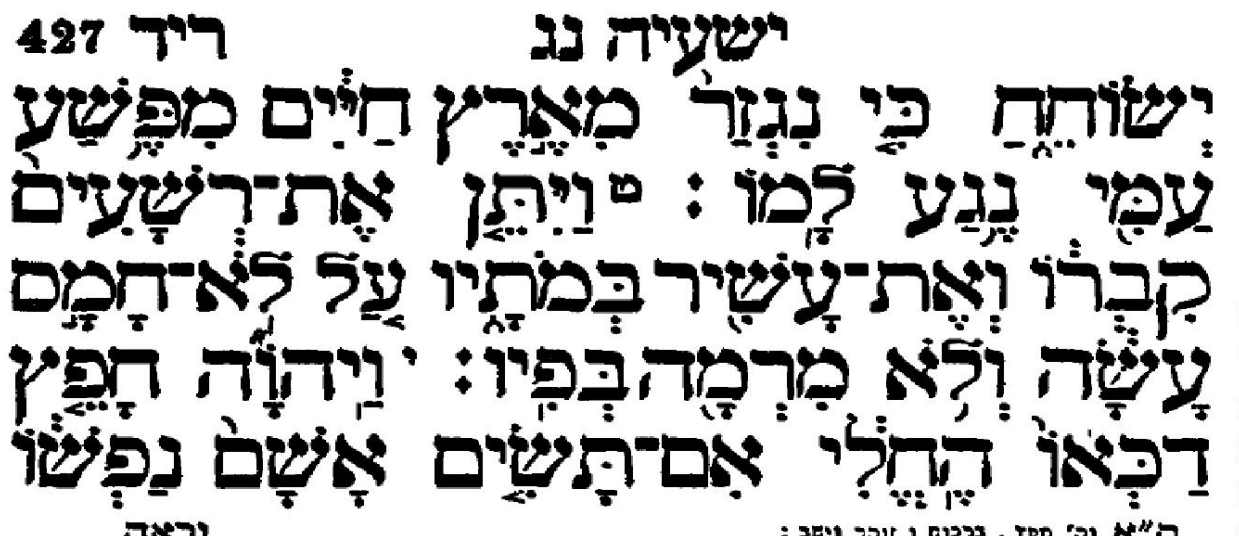

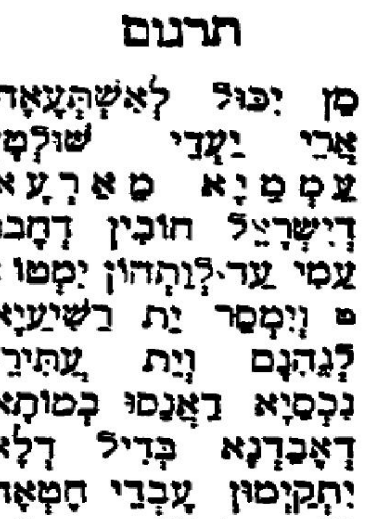

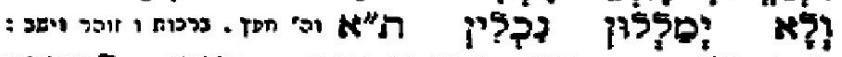

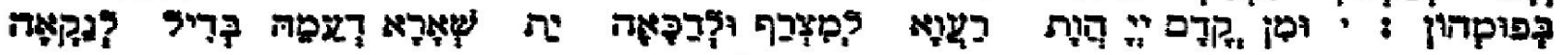

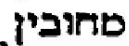

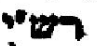

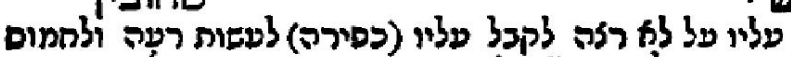

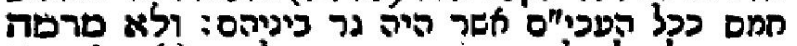

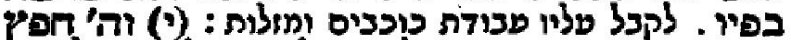

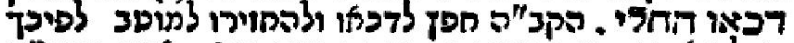

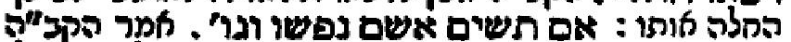

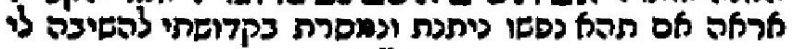
רדיקות

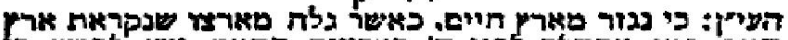

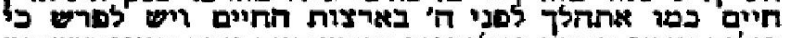

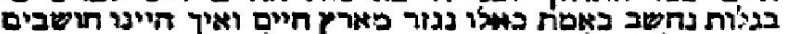

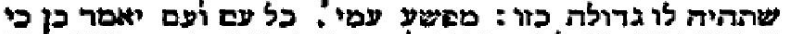

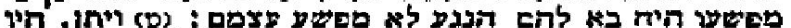

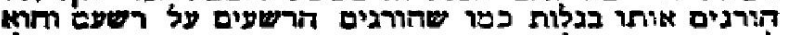

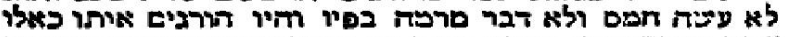

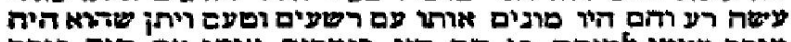

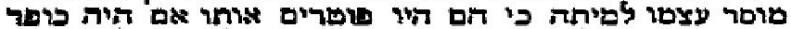

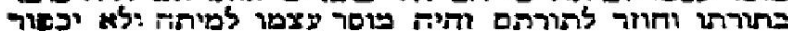

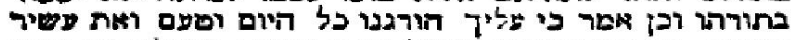

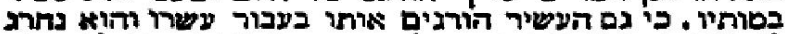

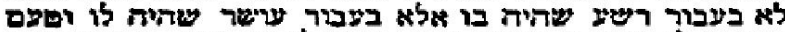

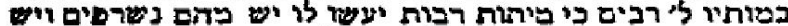

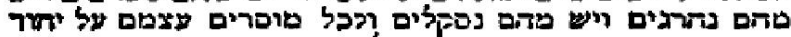

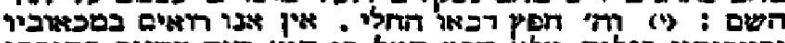

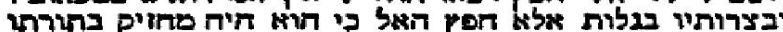

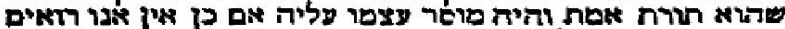

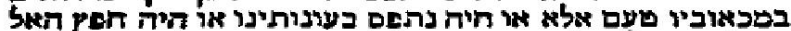

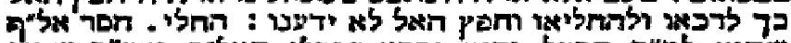

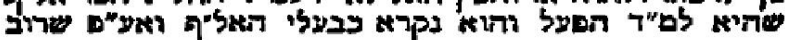

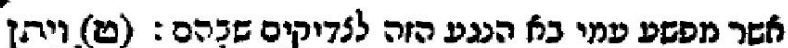

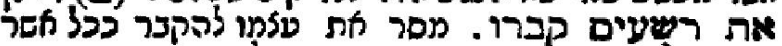

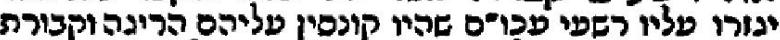

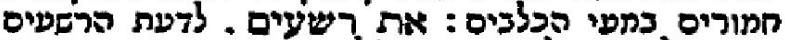

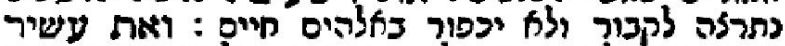

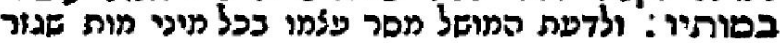

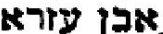

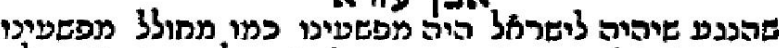

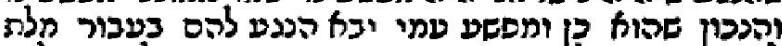

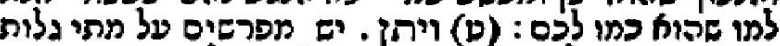

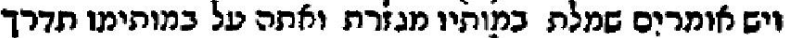
ווהסעס בכין שישם של הקבר והנה יהיה במותיו כמו קברי: וארת עשיר. כמו ואת רשעים ועשם הגוים שה בהם עשירים

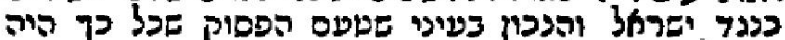

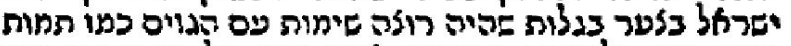

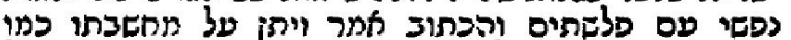

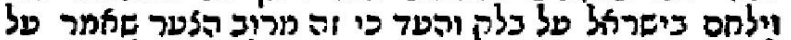

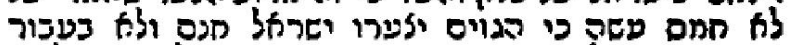

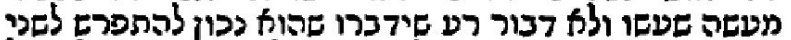

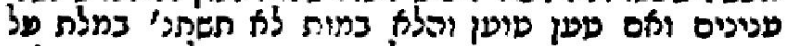

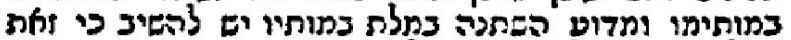

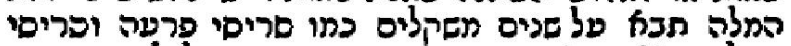

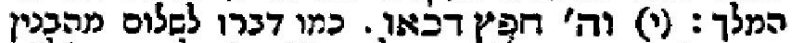

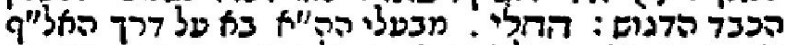

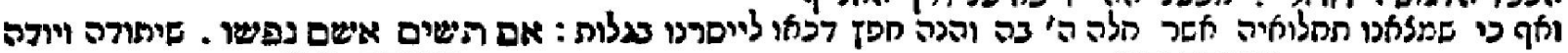

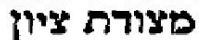

טשו

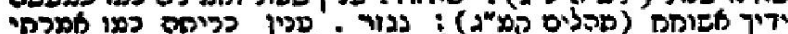

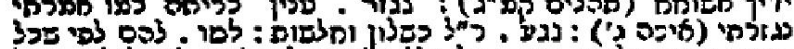

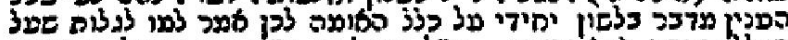

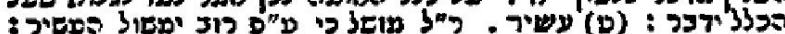

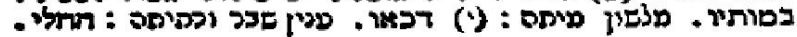

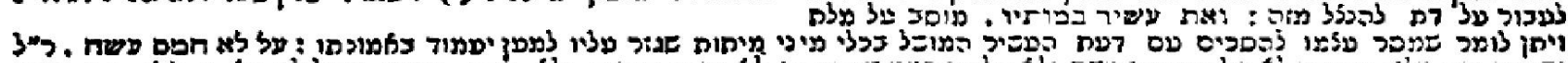

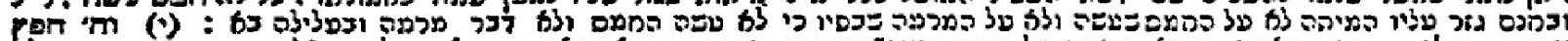

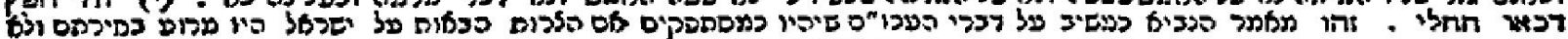

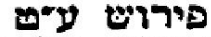

איב

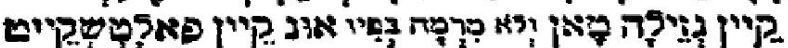

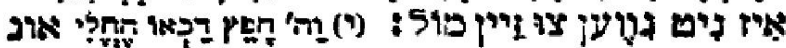
萑

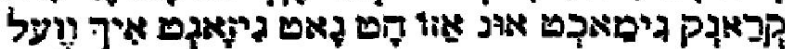

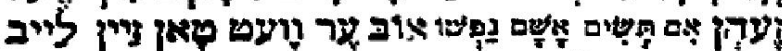

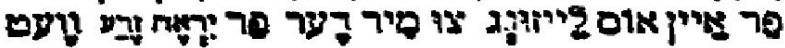

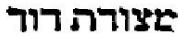

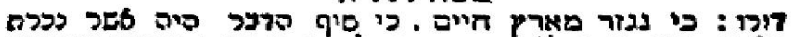

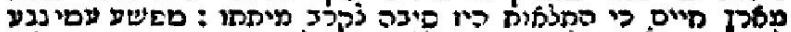

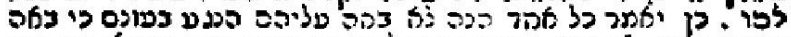

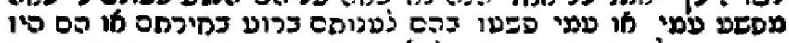

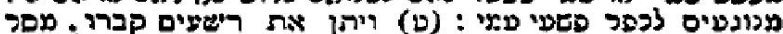

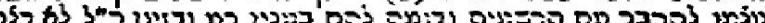

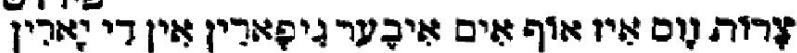

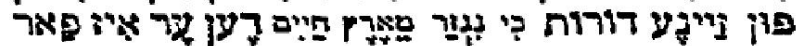
3ำ

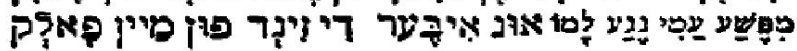

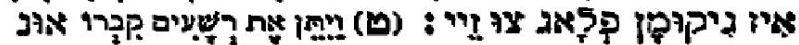

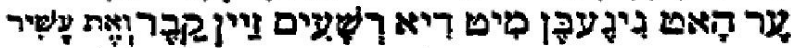
放 


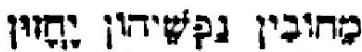

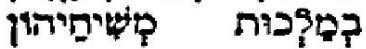

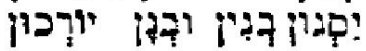

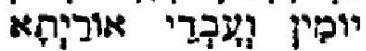

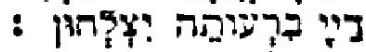

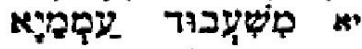

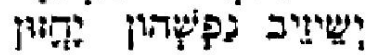

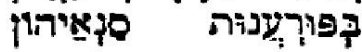

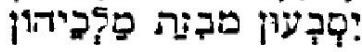

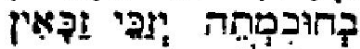

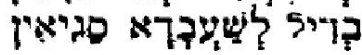

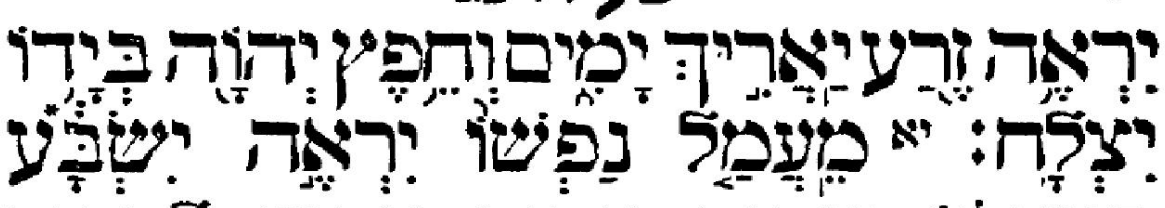
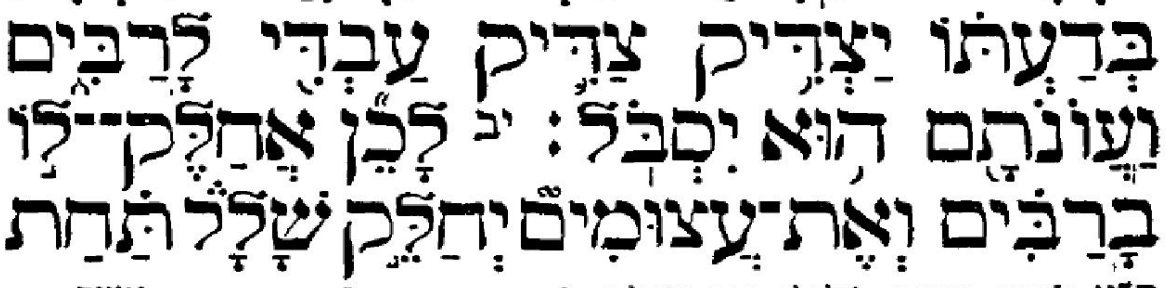
אשיר קות

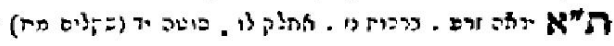

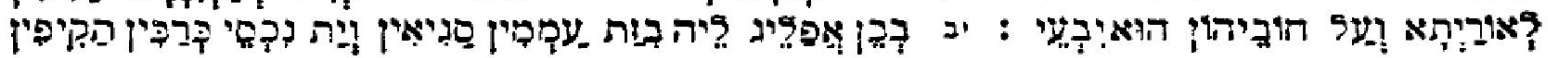
יפדים

רטס

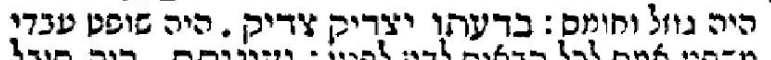

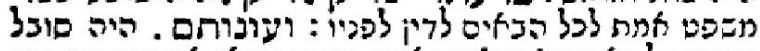

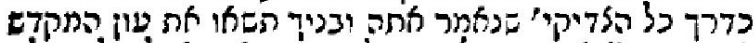

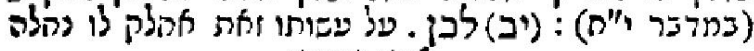
x"

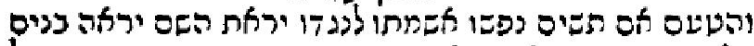

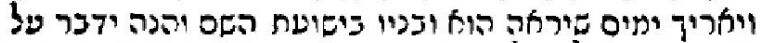

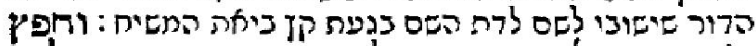

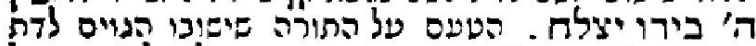

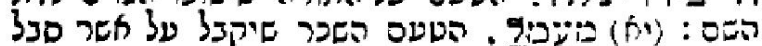

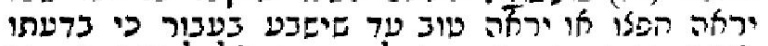

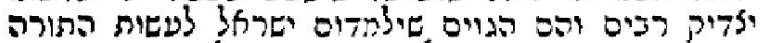

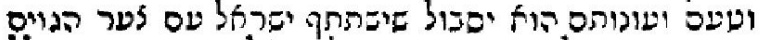

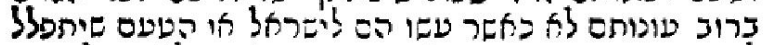

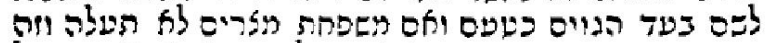

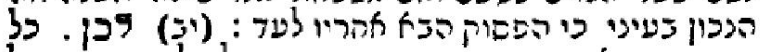

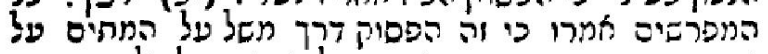

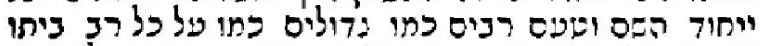

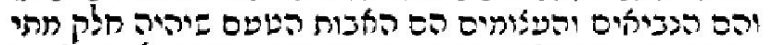

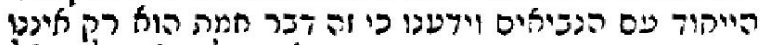

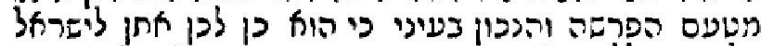

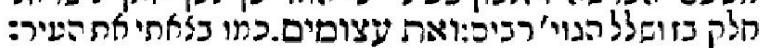

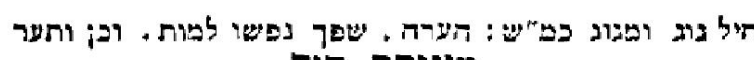

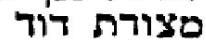

63 בגיכה המקו" 300 610

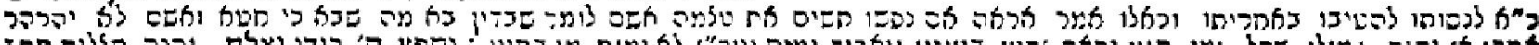

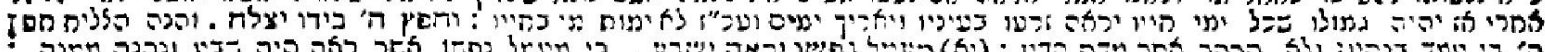

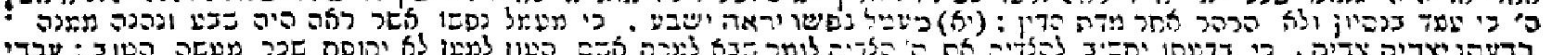

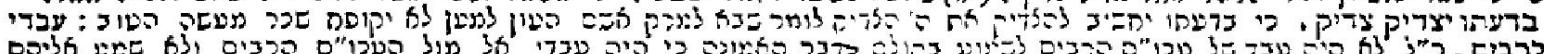

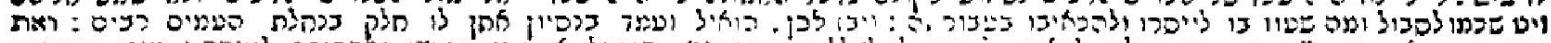

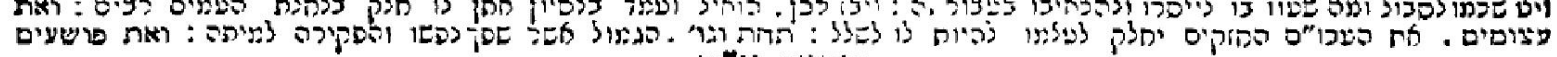
פירוט

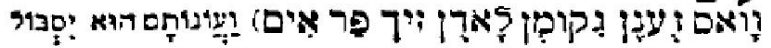

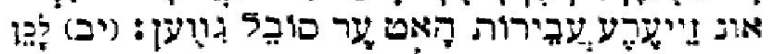

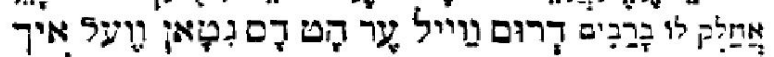
טים

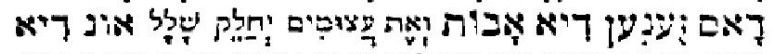

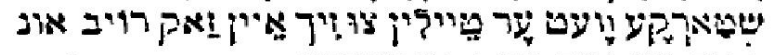

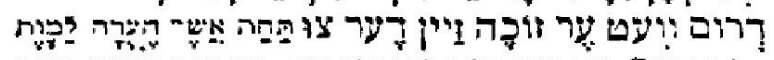

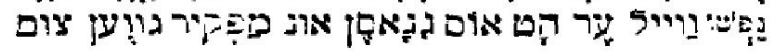
ㄴ.

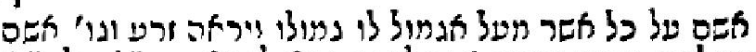

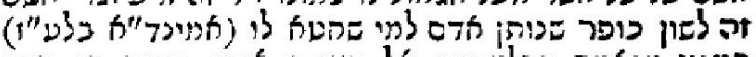

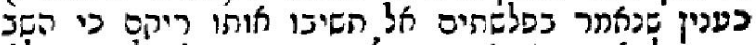

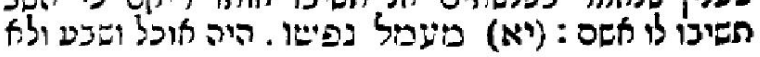

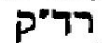

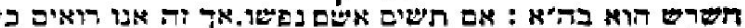

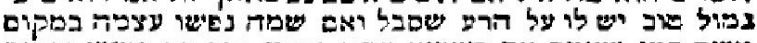
המשי

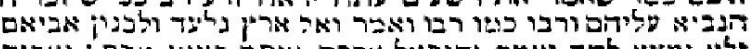

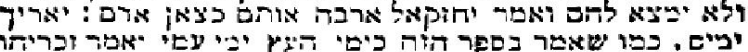

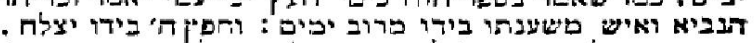

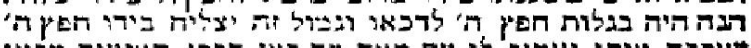

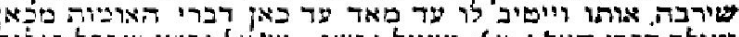

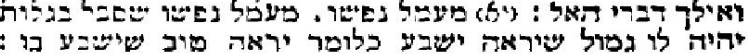

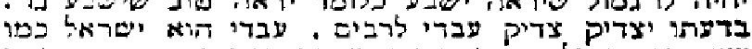

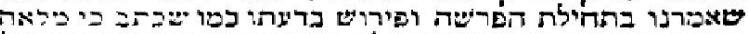

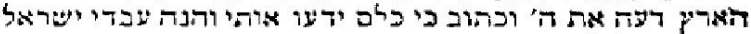

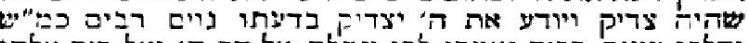

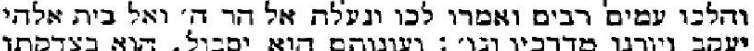

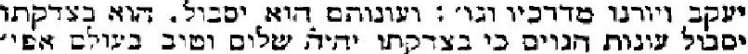

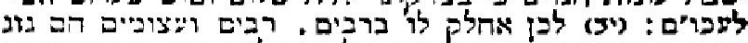

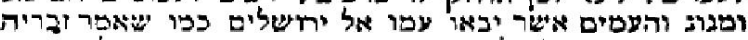

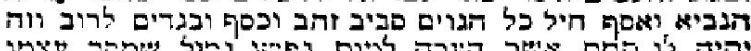

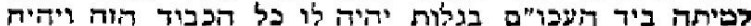

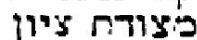

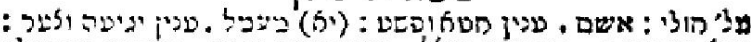

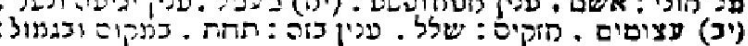

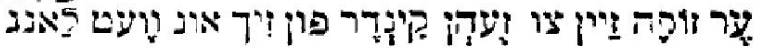

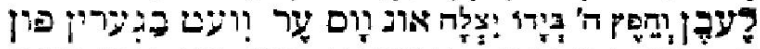
Lע גים

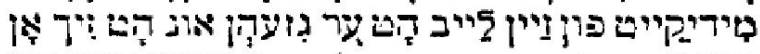

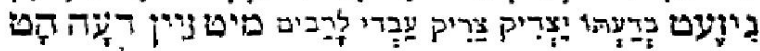

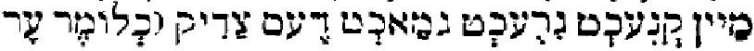

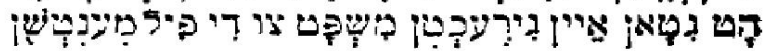




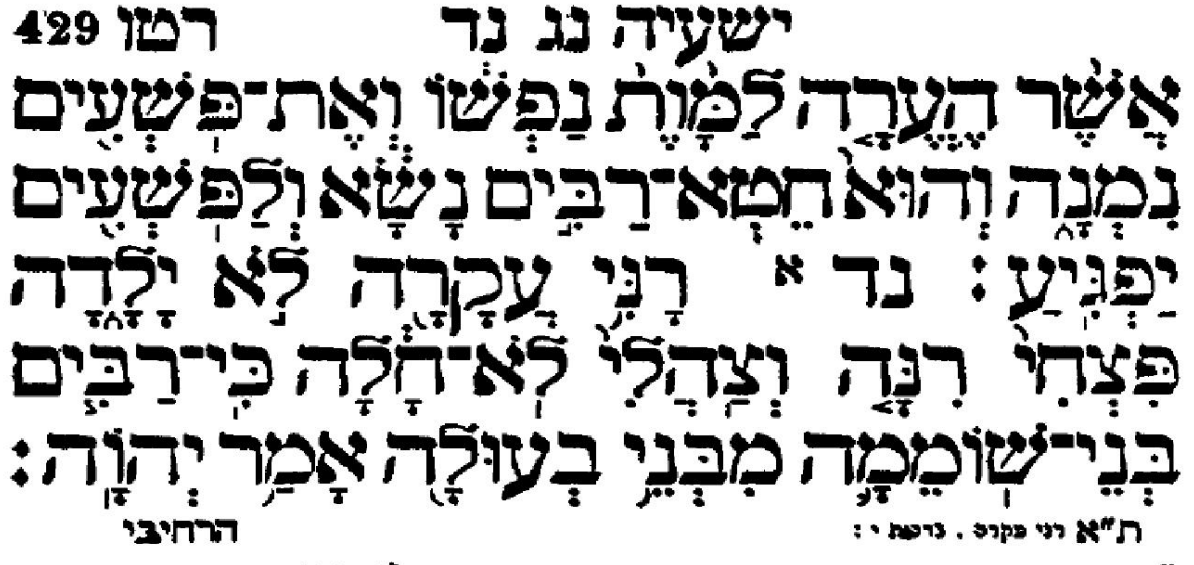

טרור

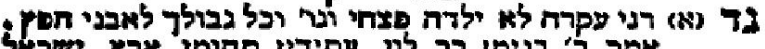

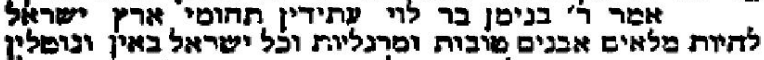

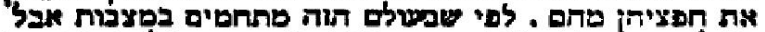

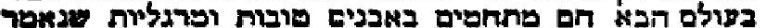

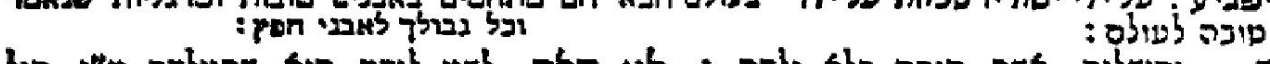

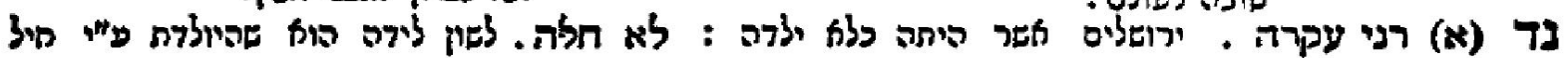

$$
\text { קריר }
$$

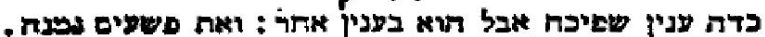

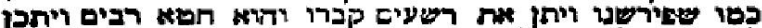

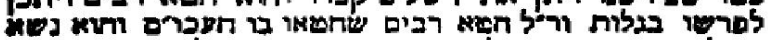

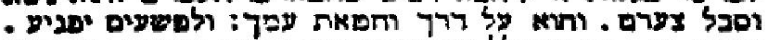

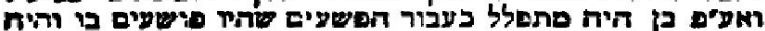

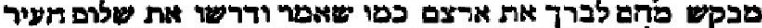

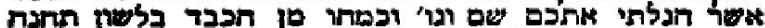

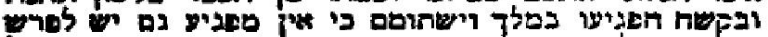

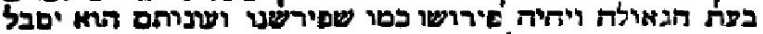

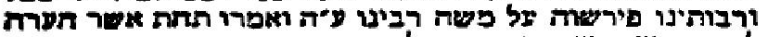

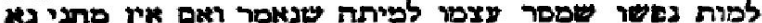

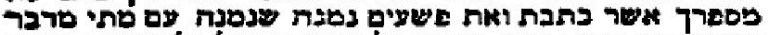

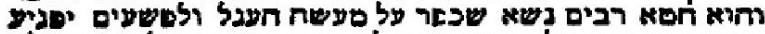

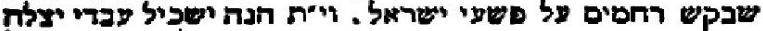

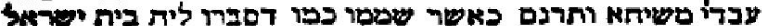

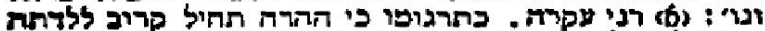

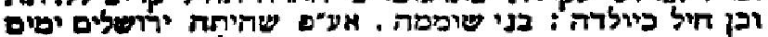

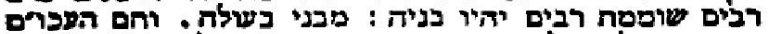

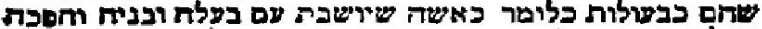

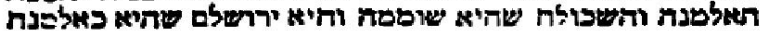

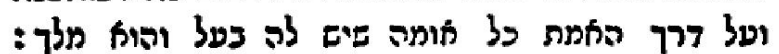

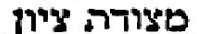

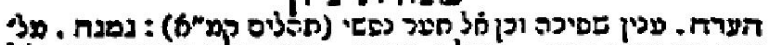

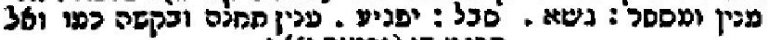

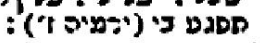

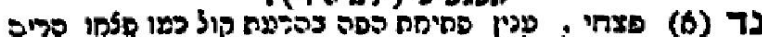

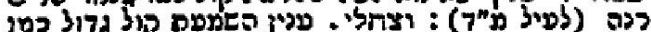

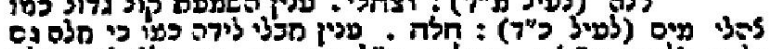

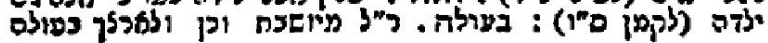

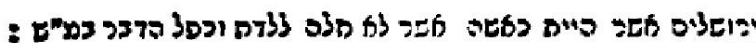
a"

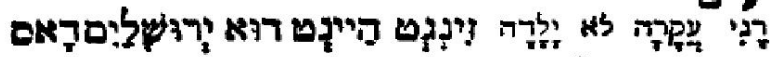

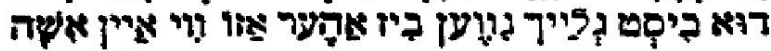
לדיל

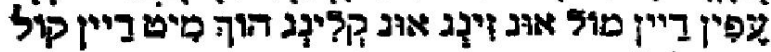
דרו ירוקט

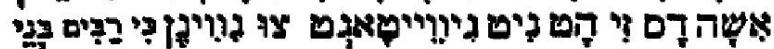

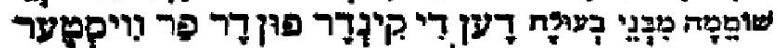
פ פ t

\section{จากา}

רดา ๆ5ก กหาร $290 \%$ תו्न M⿻コ一า

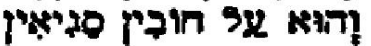

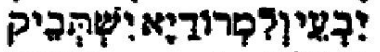
: :

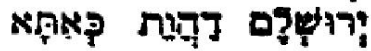
תיעם

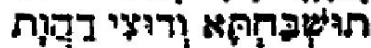

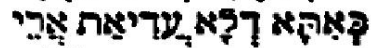

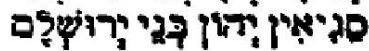
רטים

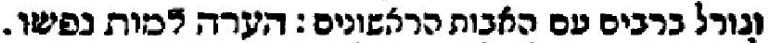

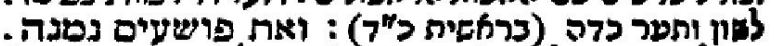

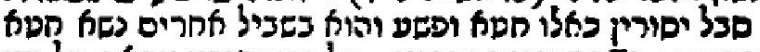

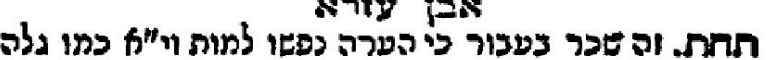
ואים

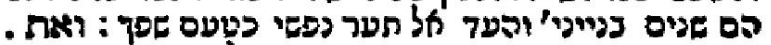

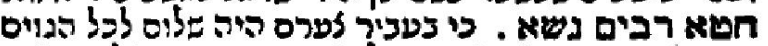

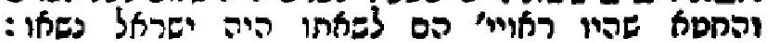

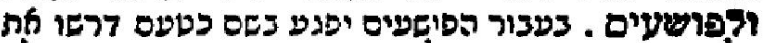

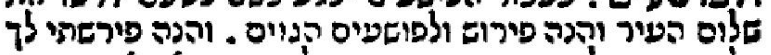

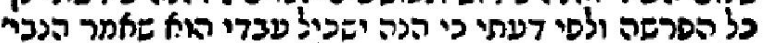

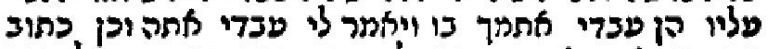

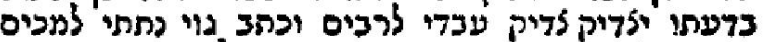

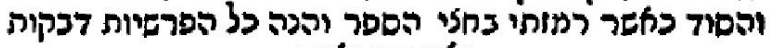

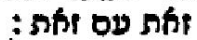

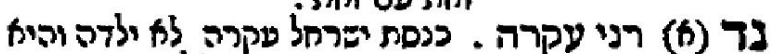

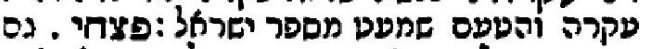

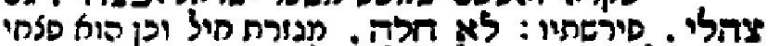

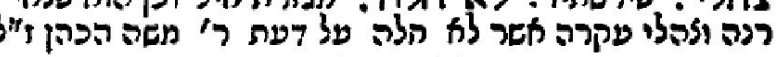

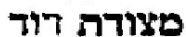

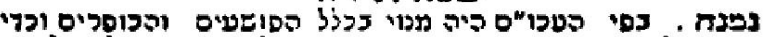
מט

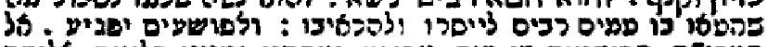

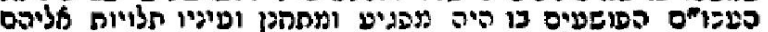

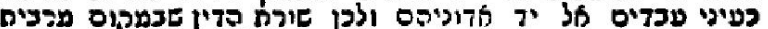

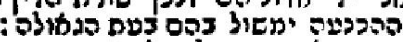

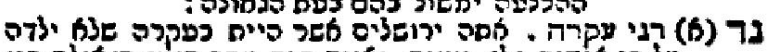

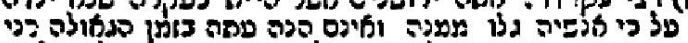

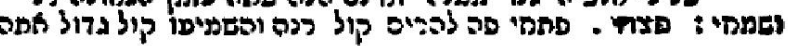
פירושים

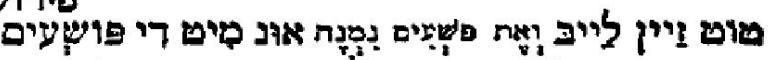

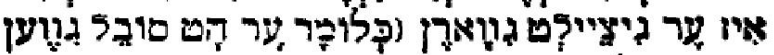

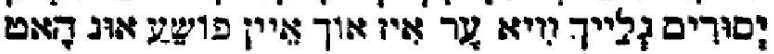

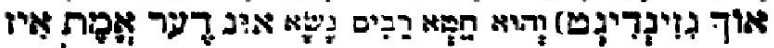

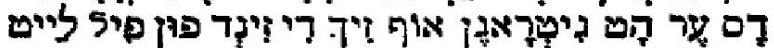

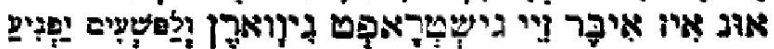

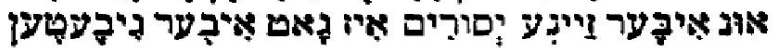

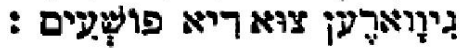

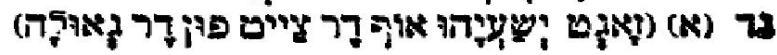

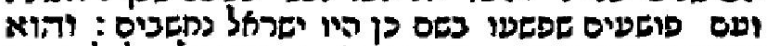




\section{BIBLIOGRAFIA}

ACKROYD, P. R.; EVANS, C. F. The Cambridge history of the Bible: from the beginnings to Jerome. v. 1. Cambridge/New York/Melbourne: Cambridge University Press, 1993 AGOSTINHO, Santo, Bispo de Hipona (354-430). A Doutrina Cristã: manual de exegese e formação cristã. Trad.: OLIVEIRA, Nair de Assis. São Paulo: Paulus, 2002

ALDEN, Robert. Lúcifer: Quem ou o que? disponível em: $<$ http://www.monergismo.com/textos/comentarios/lucifer-quem-oque_robertalden.pdf $>$ acesso em: 02 mar. 2011

ALMEIDA, Napoleão Mendes de. Gramática Latina: curso único e completo. 20. ${ }^{a}$ ed. São Paulo: Saraiva, 1985

ARROJO, Rosemary. Oficina de Tradução. 4. ${ }^{\text {a }}$ ed. São Paulo: Ática, 2000 . Tradução, Desconstrução e Psicanálise. Rio de Janeiro: Imago, 1993

ANKERBERG, John; WELDON. John. Os Fatos Sobre Jesus, o Messias. Rio Grande do Sul: Obra Missionária Chamada da Meia-Noite, 1993

ARAÚJO, Reginaldo. Gramática do Aramaico Bíblico. São Paulo: Targumim, 2005

ARCHER Jr, Gleason L.. Merece confiança o Antigo Testamento? São Paulo: Edições Vida Nova, 1991

ARCHER, Jr. Gleason L. Archer. Merece Confiança o Antigo Testamento? 3. ${ }^{a}$ Ed. São Paulo: Edições Vida Nova, 2005

AUSUBEL, Nathan. Conhecimento Judaico II. Rio de Janeiro: A. KOOGAN editor, 1989

AUVRAY, Paul. Iniciação ao Hebraico Bíblico. 2 ed. Rio de Janeiro: Vozes, 1997

AVRAHAM, Dan Ben. Israel Misterio y Revelación. Florida: USA: ComVisión 2000 Internacional, 1997

AZEREDO, José Carlos de. Gramática Houaiss da Lingua Portuguesa. São Paulo: Publifolha, 2010

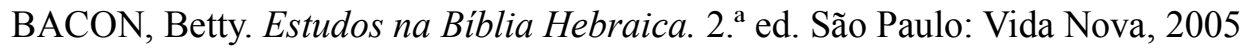

BAKER, Mona. In the other words: a coursebook on translation. Londo/New York: 
Routledge, 1994

BALLARD, Michel; D'HULST, Lieven (orgs.). Pour une ethique du traducteur. Collection Traductologie. Otaua: Artois Presses Université, 1997

BANCROFT, E. H. Teologia elementar. 3. a Ed. São Paulo: Editora Batista Regular, 1998

BARNARD, Alan; SPENCER, Jonathan (editores). 3. ed. Encyclopedia of Social and Cultural Anthropology. London / New York: Routledge, 2002

BARNWELL, Katharine. Tradução bíblica: um curso introdutório aos princípios básicos de tradução. Tradução Dr. ${ }^{a}$ Mary Daniel. Barueri, SP: Sociedade Bíblica do Brasil; Anapolis, GO: Associação Internacional de Linguística, 2011

BARRERA, Julio Trebolle. The Jewish Bible and the Christian Bible: an introduction to the history of the Bible. New York: BRILL, 1998

BARTON, John (ed.). The Cambridge companion to Biblical Interpretation. Cambridge, UK: Cambridge University Press, 1998

BASSNET, Susan. Estudos de tradução: fundamentos de uma disciplina. Lisboa: Fundação Calouste Gulbenkian, 2003

BAUMGARTNER, W. (editor). Gramática Elementar da Lingua Hebraica. 7. ${ }^{a}$ Ed. São Leopoldo. RS: 1991

BEEKMAN, John; CALLOW, John. A arte de interpretar e comunicar a palavra escrita. São Paulo: Vida Nova, 1992

BEN AVRAHAM, Dan. Israel, misterio y revelación. Florida: Comvisión 2000 Internacional, 1997

BEREZIN, Jaffa Rifka. Dicionário Hebraico-Português. São Paulo: Editora da Universidade de São Paulo, 1995

BERKHOF, Louis. Princípios de Interpretação Bíblica. 3. ed. Revisada. Rio de Janeiro: Juerp, 2008

BERMAN, Antoine. A prova do estrangeiro. Bauru, SP: EDUSC, 2002

BIBLE. O.T. English. Tanakh, a new translation of the Holy Scriptures according to the traditional Hebrew text. Philadelphia / Jerusalém: The Jewish Publication Society, 1985

BIBLE. English. Today English Version. New York: Amercian Bible Society. 1976/1972 
BIBLE WORKS. Bible Works 7.0. Norfolk, VA: Bible Works, 2005. DVD-ROM

BÍBLIA DE ESTUDO DE GENEBRA. Português. São Paulo: Cultura Cristã / SBB, 1999

BÍBLIA DE ESTUDO PLENITUDE. Português. São Paulo: SBB, 2001

BIBLIA HEBRAICA STTUTGARTENSIA. Hebraico. Editio quinta emendata. Sttutgart /

Brasília: Deutsche Bibelgesellschaft / Sociedade Bíblica do Brasil, 2007

BÍBLIA DE JERUSALÉM. São Paulo: Paulus, 2011

BÍBLIA NO BRASIL, A. A Arte de Traduzir a Bíblia. Barueri, SP: Sociedade Bíblica do Brasil, Jul a Set de 2001. Ed. n. 192, p. 13-16

100 milhões de Bíblias. Barueri, SP: Sociedade Bíblica do Brasil, Abr a Jun 2011. Ed. 231, p. 13

BIBLIA SACRA VULGATA. Latim. Editio quinta. WEBER-GRYSON. Alemanha: Deutsche Bibelgesellschaft, 2007

BÍBliA SAGRADA COM MAPAS E REFERÊNCIAS, A. Português. Almeida Corrigida Fiel. São Paulo: Sociedade Bíblica Trinitariana, 2007

BÍBLIA SAGRADA. Português. Edições Paulinas. 10 ed. São Paulo: Paulinas, 1982

BÍBLIA SAGRADA, A. Português. Almeida Corrigida Fiel. São Paulo: SBT, 1995

BÍBLIA SAGRADA. Português. Almeida Revista e Corrigida. São Paulo: SBB, 1995

BÍBLIA. Hebraico. Bíblia Hebraica. Editada por Rudolf KITTEL \& P. KAHLE. New York/Stuttgart: The American Biblie Society \& Württembergische Bibelanstalt, s/d.

BÍBLIA. Português. A Bíblia Sagrada. Edição Corrigida e Revisada Fiel ao Texto Original. São Paulo: Sociedade Bíblica Trinitariana, 2007

BÍBLIA. Português. A Bíblia Sagrada. Tradução Antonio Pereira de Figueiredo. Londres: Harrison e Filhos, 1866

BÍBLIA. Português. Bíblia de Estudo de Avivamento e Renovação Espiritual. Barueri, SP: Sociedade Bíblica do Brasil, 2009

BÍBLIA. Português. Bíblia de Estudo Despertar. Nova Tradução na Linguagem de Hoje. Barueri, SP: Sociedade Bíblica do Brasil, 2005

BÍBLIA. Português. Bíblia de Estudo Nova Tradução na Linguagem de Hoje. Barueri, SP: Sociedade Bíblica do Brasil, 2008

BÍBLIA. Português. Bíblia Hebraica. Tradução por David Gorodovits e Jairo Fridlin. São Paulo: Editora e Livraria Sêfer Ltda., 2006 
BÍBLIA. Português. Bíblia Sagrada Edições Paulinas. 8a ed. Tradução da Vulgata pelo Pe. Matos Soares. São Paulo: Edições Paulinas, 1980

BÍBLIA. Português-Inglês. Novo Testamento português-inglês. Nova Versão Internacional / New International Version. São Paulo: Editora Vida, 2004

BÍBLIA. Siríaco. Katvah Qadîsha'. London: Trinitarian Bible Society, 1913

BÍBLIA. Português. Nova Bíblia Viva. São Paulo: Mundo Cristão, 2010

BÍBLIA SACRA VULGATA. Latim. Editio quinta. Weber-Gryson. Sttutgart: Deutsche Bibelgesellschaft, 2007

BLECH, Rabino Benjamin. O mais completo guia sobre Judaismo. São Paulo: Editora e Livraria Sêfer Ltda., 2004

BLENKINSOPP, Joseph. Isaiah 40-55: a new translation with introduction and commentary. The Anchor Yale Bible. vol. XIXa. New Haven, USA/London, UK: Yale University Press, 2002

BOCK, Darrel L.; GLASER, Mitch. The gospel according to Isaiah 53: encountering the suffering servant in jewish and Christian theology. Dallas: Kregel Academic \& Professional, 2012

BOHLMANN, Ralph A. Princípios de Interpretação Bíblica nas Confissões Luteranas. Trad. REHFELDT, Mário L. Porto Alegre: Casa Publicadora Concórdia S. A., 1970

BOLOZKY, Shmuel. 501 Hebrews Verbs. Nova Iorque/Canadá: Barron's Educational Series Inc, 1996

BORGER, Hans. Uma História do Povo Judeu. vol 1 - de Canaã à Espanha. 2. ${ }^{\text {a }}$ Ed. São Paulo: Editora e Livraria Sêfer, 1999

BRAGA, James. Cómo preparar mensajes bíblicos. Michigan: Editorial Portavoz, 1986

BRENNAN, ROBERT J. e CORRÊA, DAVID R. D, Profecias Messiânicas. São Paulo: Edição Própria, 1989

BRIGHT, John. História de Israel. 8. a Ed. São Paulo: Paulus, 2003

BROWKER, John. The Targums \& Rabbinic Literature: an introduction to jewish interpretations of Scripture. Cambridge: Cambridge University Press, 2009

BROWN, Colin; COENEN, Lothar (orgs.). Dicionário Internacional de Teologia do Novo Testamento. 2. ${ }^{\text {a }}$ Ed. São Paulo: Vida Nova, 2000

BUNIM, Irvim M.(1998). A Ética do Sinai. São Paulo: Editora e Livraria Sêfer, 1988 
BURNS, Bárbara; AZEVEDO, Délcio; CARMINATI, Paulo Barbero F. de. Costumes e culturas: uma introdução à antropologia missionária, baseado na obra de E. A. Nida São Paulo: Vida Nova, 1995

CABTREe, Asa R. Sintaxe do Hebraico do Velho Testamento. Rio de Janeiro: Casa Publicadora Batista, 1951

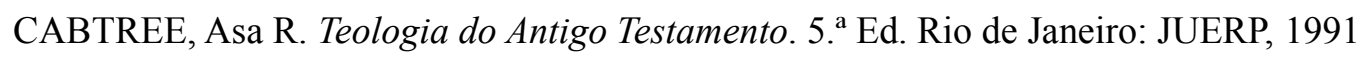

CALVINO, John. Commentary on The Book of The Prophet Isaiah. Translated from the original Latim, and collated with the lastest french version, by The Rev. William Pringle. Vol.III. Micuigan / USA: Baker Books, 2005 . Institución de la religión cristiana. 6 ed. Barcelona: FELIRE, 2006

CAMPOS, Haroldo de. Bere'shith, a cena da origem: (e outros estudos de poética bíblica). São Paulo: Perspectiva, 2000 - Qohelet $=$ O-que-sabe: Eclesiastes: poema sapiencial. 2.a ed. São Paulo: Editora Perspectiva S.A., 1991

CAMPOS, Jorge; RAUEN, Fábio José (orgs.). Tópicos em Teoria da Relevância. Porto Alegre: EDIPUCRS, 2008, disponível em:

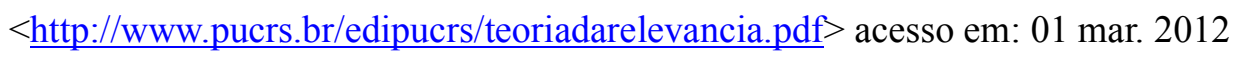

CARMI, T. (Ed.) The Peguin Book of Hebrew Verse. New York: Viking Peguin Inc., 1981

CATFORD, J. C. Uma Teoria Linguística da Tradução. Campinas: Pontifícia Universidade Católica de Campinas, 1980

CHAMPLIN, Russell Norman. O Antigo Testamento interpretado: versículo por versículo. Vol. 5. São Paulo: Editora Candeia, 2000

CHAVEZ, Moises. Dicionario de Hebreo Biblico. El Paso, USA: Editorial Mundo HIspano, 1992

CHAMBERLAIN, William Douglas. Gramática Exegética do Grego Neo-Testamentário. São Paulo, 1989

CHESTERMAN, Andrew. Proposal for a Hieronymic Oath. In: PYM, Anthony (Editor Convidado). The Translator: Studies in Intercultural Communication. Special Issue: The Return to Ethics., UK: St. Jerome Publishing, vol. 7, n. 2, p. 150-151, 2001

COHEN, Peter. Isaiah 53. Messianic Good News S.A. New York/South Africa: s/e, 1999 . Messiah - Born of a Virgin. Messianic Good News S.A. New York/South Africa: s/e, 1999 
Why do the rabbis reject Jesus?. Messianic Good News S.A. New York/South Africa: s/e, 1999

CONGRESSO NACIONAL DA BÍBLIA, 2. ${ }^{\circ}, 12$ a 17 de Dezembro de 1979, Brasília. Teses Apresentadas no II Congresso Nacional da Bíblia: Sociedade Bíblica do Brasil, $1979,216 \mathrm{p}$.

CROSSAN, John Dominic. Quem Matou Jesus? as raizes dos antisemitismo na história evangélica da morte de Jesus. Coleção Bereshit. São Paulo: Imago Editora Ltda., 1995

CUDDON, J. A. The peguin dictionary of literary terms and literary theory. Revisado por C.

E. Preston. London, UK: Peguin Books, 1998

DAVIDSON, Benjamin. The Analytical Hebrew and Chaldee Lexicon. Michigan, USA: Zondervan, 1993

DAVIDSON, Rev. A. B. Introductory Hebrew Grammar, Hebrew Syntax. 3. ${ }^{a}$ Ed. Endinburg: T \& T Clark; New York: Charles Scribner's Sons, 1924

DAY, John (org.). Rei e Messias em Israel e no Antigo Oriente Próximo. São Paulo: Paulinas, 2005

DALY, Kevin. A Christian response to Asher Norman's claims on Isaiah 53. Messianic Good News, New York: Messianica Good News, p. 12-24, Set 2007

DORIVAL, Gilles; HARL, Marguerite; MUNNICH, Olivier. La Bible Grecque des Septante: Du judaïsme hellénistique au christianisme ancien. Paris: Éditions du CERF / Éditions du C.N.R.S., 1994

DOUGLAS, J. D. (org.). O Novo Diconário da Bíblia. 2. ${ }^{a}$ Ed. São Paulo: Vida Nova, 1995

DRIVER, S. R.; NEUBAUER, AD. Fifty-Third chapter of Isaiah according to the jewish interpreters: with an introduction to the translations by Rev. E. B. Pusey Regius Professor of Hebrew Oxford. Vol II: Translations. Oxford/London/Leipzig: James Parker and Co./T. O. Weigel, 1877

DUBOIS, Jean. GIACOMO, Mathée; GUESPIN, Louis; MARCELLESI, Christiane; MARCELLESI, Jean-Baptiste; MEVEL, Jean-Pierre. Dicionário de Lingüistica. São Paulo: Editora Cultrix, 2006

ECO, Humberto. Quase a mesma coisa. Rio de Janeiro: Record, 2007 . Os limites da interpretação. São Paulo: Perspectiva, 2012

EDERSHEIM, Alfred. La Vida y Los Tiempos de Jesus el Messias. Tomo I. Barcelona: Libros Clie, 1988 
EAGLETON, Terry. Ideologia. São Paulo: Boi Tempo Editorial / Editora da Unesp, 1997

EICHRODT, Walther. Teologia do Antigo Testamento. São Paulo: Hagnos, 2004

ELLISEN, STANLEY A. Conheça melhor o Antigo Testamento. São Paulo: Ed. Vida,

ERICKSON, Millard J. Introdução à Teologia Sistemática. São Paulo: Vida Nova, 1997

EVEN-SHOSHAN, Avraham. Milon HeHadash. Jerusalém: Editora Qiriat-Sêfer, 1979 [hebraico]

FABRY, Heinz-Josef; SCHOLTISSEK, Klaus. O Messias. Bíblica Loyola 53. São Paulo: Edições Loyola, 2008

FAIRCLOUGH, Norman. Discurso e mudança social. Brasília: Editora da Universidade de Brasília, 2001

FARRAR, Frederic W. History of Interpretation. London: Macmillan and Co., 1886

FISHBANE, Michael. Biblical Interpretation in Ancient Israel. Oxford: Oxford University Press, 1988

FÓRUM DE CIÊNCIAS BÍBLICAS, VII, 18 a 19 de Agosto de 2011, Barueri, SP. São Paulo: SBB

FRANCISCO, Edson de Faria. Manual da Bíblia Hebraica. 3. ${ }^{a}$ Ed. São Paulo: Vida Nova, 2008

FRIDLIN, Jairo (coordenador). Torá, a Lei de Moisés. São Paulo: Editora e Livraria Sêfer, 2001

FRYE, Northrop. O código dos códigos: a Bíblia e a literatura. São Paulo: Boitempo, 2004

GAEBELEIN, Frank E. (editor). Version: Isaiah, jeremiah, Lamentations, Ezekiel. Vol. 6. Michigan / USA: Zordevan, 1986

GARDINER, Frederic. The Old and New Testament in Their Mutual Relation. Nova York: James Port, 1885

GEISLER, Norman L.; HOWE, Tomas. Manual popular de dúvidas, enigmas e “contradições” da Bíblia. São Paulo: Mundo Cristão, 1999

GILBERT, George Holley. Interpretation of the Bible: a short history. New York: Macmillan and Company, 1908

GINTZBURG, David. Hebrew Old Testament. Londres: Trinitarian Bible Society, 1894, 1998

GOHN, Carlos; NASCIMENTO, Lyslei. A Bíblia e suas traduções. Coleção Judaica. São Paulo: Humanitas, 2009

GOLDBERG, David J. e RAYNER. John D. Os judeus e o judaísmo. Rio de Janeiro: Xenon 
Ed., 1989

GRONINGEN, Gerard van. Revelação Messiânica no Velho Testamento. Campinas, SP: Luz Para o Caminho (LPC Publicações), 1995

GRUDEM, Wayne. Teologia Sistemática. Edições. São Paulo: Vida Nova, 1999

GRYLAK, Moshe. Reflexões sobre a Torá. São Paulo: Editora e Livraria Sefer, 1998

GUTT, Ernst-August. Translation and Relevance: cognition an Context. Manchester, U.K.: St Jerome Publishing, 2000

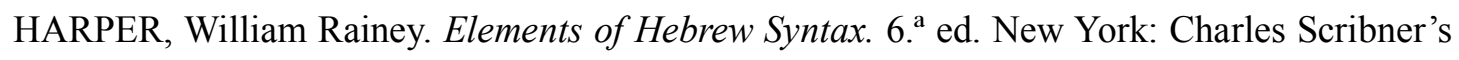
sons, 1901

HARRIS, R. Laird, ARCHER Jr, Gleason L. e WALTKE, Bruce K. Dicionário Internacional de Teologia do Antigo Testamento. São Paulo: Edições Vida Nova, 1998

HATIM, Basil. Communication Across Cultures: translation theory and constrative text linguistics. U.K.: Exeter Linguistic Studies, 1997

HATIM, Basil; MASON, Ian. Form and function in the translation of the sacred and sensitive text: In: The translator as comunicator. New York: Routledge, 1997

HATZAMRI, Abraham e MORE-HATZAMRI Shoshana. Dicionário Português-Hebraico Hebraico-Português. 2. ${ }^{\mathrm{a}}$ Ed. Jerusalém: Aurora, 1995

HOBBS, Herschel H. Os Fundamentos da nossa Fé. 3. a Ed. Rio de Janeiro: JUERP, 1960

HODGES, Zane C.; FARSTAD, Arthur. Novo Testamento Interlinear Analítico. 2. ${ }^{a}$ Ed. São Paulo: Cultura Cristã, 2008

HOUAISS, Antônio; VILLAR, Mauro de Salles. Dicionário Houaiss da Língua Portuguesa. Rio de Janeiro: Objetiva, 2001

HOUSE, Juliane. Translation. Oxford: Oxford University Press, 2009

HOUSE, Paul R. Teologia do Antigo Testamento. São Paulo: Vida, 2005

JASTROW, M. A dictionary of the Targumim, the Talmud Babli and Yerushalmi, and the Midrashic Literature. Nova York: G. P. Putnam's Sons, 1903

JOÜON, P. Paul S. J. Grammaire de L'Hebreu Biblique. Roma: Institut Biblique Pontifical, 1947

JUSTINO, MÁRTIR, SANTO JUSTINO DE ROMA. I e II apologias: diálogo com Trifão. Introdução e notas Roque Frangiotti; tradução Ivo Storniolo, Euclides M. Balancin. São Paulo: Paulus, 1995

KAISER Jr., Walter. Teologia do Antigo Testamento. São Paulo: Ed. Vida Nova, 1999

KAISER Jr., Walter; SILVA, Moisés. Introdução à Hermenêutica Bíblica. São Paulo: Editora 
Cultura Cristã, 2002

KAUTZSCH, E. \& COWLEY, A. E. (EDITORES). Gesenius' Hebrew Grammar. Oxford: Clarendon Press, 1909

KERR, Guilherme. Gramática Elementar da Língua Hebraica. Rio de Janeiro: JUERP, 1979

KIPPENBERG, Hans G. Religião e Formação de Classes na Antiga Judéia. São Paulo: Paulinas, 1988

KIRST, Nelson et al. Dicionário Hebraico-Português e Aramaico-Português. São Leopoldo: Sinodal, 1994

KOLATCH, Alfred J.. O segundo livro judaico dos porquês. São Paulo: Editora e Livraria Sêfer, 1998

KRAMER, Jaim. Mashiaj: ¿Quién? ¿Qué? ¿Por que? ¿Dónde? y ¿Cuándo? Jerusalem/New York: Breslov Research Institute, 1997

LAKE, Kirsopp. Apostolic Fathers in Greek. Grand Rapids, MI: Christian Classics Ethereal Library, 1913. Disponível em: <http://www.ccel.org/ccel/lake/fathers2.html> acesso em: 15 mar. 2013

LAMBDIN, Thomas O. Gramática do Hebraico Bíblico. São Paulo: Paulus, 1988

LANGE, John Peter. A Commentary on the Holy Scriptures: critical, doctrinal and homiletical, special reference to ministers and students. Translated from the german, and edited, with additions, orginal and selected: SCHAFF, Philip. New York: Charles Scribner's Sons, [1878?]

LANGSTON, A. B. Esboço de Teologia Sistemática. São Paulo: JUERP, 1999

LENHARDT, P.; COLIN, M. A Torah Oral dos Fariseus: Textos da Tradição de Israel. Documentos do Mundo da Bíblia - 10. São Paulo: Paulus, 1997

LERER, Bernardo. Inédito, um Tanach em português! in: $<$ http://www.sefer.com.br/details/9003/biblia-hebraica $>$ acesso em: 18 set. 2013

LINS, Brandão Jacinto et.alii. Helleniká: introdução ao grego antigo. Belo Horizonte: Editora UFMG, 2009

LONGFIELD, Rev. George. An Introduction to the Study of the Chaldee Language: Comprising a Grammar (based upon Winer's), and an Analysis of the Text of the Chaldee Portion of The Book of Daniel. Londres / Dublin: Whittaker \& Co., AveMaria Lane / Hodge, Smith, \& Co., 1859

LOPES, Mariú Moreira Madureira. A sensibilidade na tradução bíblica: aspectos linguísticos e socioculturais. São Paulo 2008. 168 p. Dissertação de Mestrado (Letras) Faculdade de Letras, Universidade Presbiteriana Mackenzie. 
LUCY, Niall. A Derrida Dictionary. Malden, MA: Blackwell Publishing, 2004

MACCOBY, Hyam (Org.). O Judaísmo em Julgamento: os debates judaicos-cristãos na Idade Média. Rio de Janeiro: Imago, 1996

MAIMÔNIDES, Moses. Epistola do Iêmen. Tradução Alice Frank. São Paulo: Maayanot, 1996

MALANGA, Eliana Branco. A Bíblia Hebraica como obra aberta: uma proposta interdisciplinar para uma semiologia bíblica. São Paulo: Associação Editorial Humanitas: Fapesp, 2005

MANUAL DO SEMINÁRIO DE CIÊNCIAS BÍBLICAS. Barueri, SP: Sociedade Bíblica do Brasil, 2008

MARKUS, Robert. O fim do cristianismo primitivo. São Paulo: Paulus, 1997

MARTIN, Ralph P.; HAWTHORNE, Gerald F.; REID, Daniel G. 2a ed. Dicionário de Paulo e suas cartas. São Paulo: Loyola / Paulus / Vida Nova, 2008

MATHER, George A. \& NICHOLS, Larry A. Dicionário de Religiões, Crenças e Ocultismo. São Paulo: Ed. Vida, 2000

MEYER, Rudolf. Gramática del Hebreo Bíblico. Traduccion del alemán por el Profesor Ángel Sáenz-Badillos. Terrassa: CLIE, 1989

MESCHONNIC, Henri. Poética do Traduzir. São Paulo: Perspectiva, 2010a . Traduzir: Escrever ou Desescrever. Scientia Traductionis, s/l: s/e, n. 7, p. $2-22,2010 \mathrm{~b}$

MILLER, Stephen; HUBER, Robert V. A Bíblia e sua história: o surgimento e o impacto da Bíblia. Barueri, SP: Sociedade Bíblica do Brasil, 2006

MITCHELL, David C. Messiah bar Ephraim in the Targums. In: Aramaic Studies. Vol 4.2 (2006): 221-241. London: Sage Publications, 2006. disponível em: < http://obinfonet.ro/docs/tpnt/tpntres/targum_messiah.pdf $>$ acesso em: 10.06.2013

MITTMANN, Solange. Notas do Tradutor e Processo Tradutório: análise sobre o ponto de vista discursivo. Porto Alegre: Editora da UFRGS, 2003

MILLER, Fred P. Great Isaiah Directory. 2001. disponível em: <http://Www.ao.net/ fmoeller/qumdir.htm> acesso em: 04.04.2011

MILLER, Stephen M.; HUBER, Robert V. A Bíblia e sua história: o surgimento e o impacto 
da Bíblia. Barueri, SP: Sociedade Bíblica do Brasil, 2006

MORRIS, Leon L. Lucas, introdução e comentário. São Paulo: Edições Vida Nova, 1983

MUNDAY, Jeremy. Introducing Translation Studies: Theories and Applications. London/New York, 2008

NEUBAUER, AD. (ed.) Fifty-Third chapter of Isaiah according to the jewish interpreters. Vol I: Texts. Oxford/London/Leipzig: James Parker and Co./T. O. Weigel, 1877

NIDA, Eugene A. Toward a Science of Translating. Leiden: E. J. Brill, 1964 - Contexts in Translation. Amsterdam/Philadelphia: John Benjamins Publishing Company, 2001 . Customs and culture. Passadena: Willian Carey Library, 1975

NIDA, Eugene A.; TABER, Charles R. The Theory and Pratice of Translation. Leiden: United Bible Society, 1982

NIDA, Eugene A.; WAAR, Jan de. From one language to another: Functional Equivalence in Bible Translating. New York: Thomas Nelson Publishers, 1986

NIDA, Eugene A.; Louw, Johannes P., (ed.). Greek-English Lexicon of the New Testament Based on Semantic Domains. New York, NY: United Bible Societies, 1988.

NOVO COMENTÁRIO BÍBLICO SÃO JERÔNIMO: ANTIGO TESTAMENTO. Trad. FERNANDES, Celso Eronides. São Paulo: Ed. Academia Cristã Ltda; Paulus, 2007

O NOVO TESTAMENTO GREGO. 4. ed. revisada. Barueri, SP: SBB/Deutsche Biblegesellschaft, 2009

O PENTATEUCO DA BÍBLIA MEDIEVAL PORTUGUESA. Introdução e glossário Heitor Megale. São Paulo: Imago / EDUC, 1992

O'SULLIVAN, Rev. Sean; BARON, David; MANSON, William; KAC, Dr. Isaiah Chapter 53: a portrait of the suffering messiah, a critical examination of the non-messianic interpretations of Isaiah 53. Messianic Good News, New York: Messianic Good News S.A., p. 1-6, 1999, disponível em: <http://www.givengain.com/cgibin/giga.cgi?cmd $=$ cause_dir_news_item\&news_id $=13060 \&$ cause_id $=1507>$ acesso em: 17 mar. 2013

OLIVEIRA, Paulo de Sousa. Estratégias de uma Missão: Salomão Ginsburg e a Construção do Ideário Batista (1890-1927). São Paulo, 1999. 199 f. Tese (Doutorado em História Social) - Faculdade de Filosofia, Letras e Ciências Humanas, Universidade de São Paulo

ORÍGENES. Tratado sobre os Princípios. Trad. João Eduardo Pinto Basto Lupi. São Paulo: Paulus, 2012 
ORLANDI, Eni P. Autoria, leitura e efeitos do trabalho simbólico. 5a. ed. Campinas, SP: Pontes, 2007

OSBORNE, Grant R. A Espiral Hermenêutica: uma nova abordagem à interpretação bíblica. São Paulo: Vida, 2009

OSWALT, John N. The Book of ISAIAH Chapters 40-66. Michigan / Cambridge: U.K., 1998

OSWALT, John N. The NVI Application Commentary Isaiah: from biblical text... to contemporary life. Michigan / USA: Zordervan, 2003

OUSTINOFF, Michaël. Tradução: história, teorias e métodos. São Paulo: Parábola Editorial, 2011

OVERMAN, J. Andrew. O Evangelho de Mateus e o Judaísmo Formativo: o mundo social da comunidade de Mateus. Bíblica Loyola 21. São Paulo: Edições Loyola, 1997

PÊCHEUX, Michel. O Discurso: estrutura ou acontecimento. Tradução: ORLANDI, Eni. 5. ed. Campinas, SP: Pontes Editores, 2008

PEREIRA, Isidro. Dicionário Grego-Português e Português-Grego. 4 ed. Porto, Portugal: Livraria Apostolado da Imprensa, 1969

PYM, Anthony (Editor Convidado). The Translator: Studies in Intercultural Communication. Special Issue: The Return to Ethics., UK: St. Jerome Publishing, vol. 7, n. 2, p. 150151,2001

. Exploring Translation Theories. London: Routledge, 2010

PAULI, Rev. C. W. H. The chaldee paraphrase on the prophet Isaiah. London: London Society's House, 1871

PORTER, Stanley E. (ed.). Dictionary of Biblical Criticism and Interpretation. London / New York: Routledge, 2007

PINTO, Carlos Osvaldo Cardoso. Fundamentos para a Exegese do Antigo Testamento. São Paulo: Vida Nova, 1998

QUEIROZ, Martha Maria Romeiro de. Do plurilinguismo em Babel ao ecumenismo na tradução bíblica: o caso da versão católica da Bíblia Sagrada - Nova Tradução na Linguagem de Hoje. Rio de Janeiro 2007. 207 p. Dissertação de Mestrado (Letras) Faculdade de Letras, Pontifícia Universidade Católica do Rio de Janeiro.

QUICHERAT, L. Novíssimo dicionário latino-português: etimológico, prosódico, histórico, geográfico, mitológico, biográfico, etc. 11.a ed. Rio de Janeiro / Belo Horizonte: Livraria Garnier, 2000

RAD, Gehard von. Teologia do Antigo Testamento. 2 ed. São Paulo: ASTE/TARGUMIM, 
RAHLFS, Alfred. Septuaginta.Barueri, SP: Sociedade Bíblica do Brasil, 2011

REMBAUM, Joel E. The development of a jewish exegetical tradition regarding Isaiah 53. The Harvard Theological Review, Cambridge: Cambridge University Press, vol. 75, n. 3, p. 289-311, 1982. Disponível em: <http://www.jstor.org/stable/1509755>. Acesso em: 18 mar. 2013.

REVISTA APOLOGÉTICA JUDAICA SHOMER YSRAEL, Ano I, N. ${ }^{\circ}$ 5, Abr/Mai 2002

ROBERTS, Rev. Alexander, D.D.; DONALDSON, James, LL.D., (eds.) The ante-nicene fathers translations of the writings of the fathers down to a.d. 325: revised and chronologically arranged, with brief prefaces and occasional notes by A. Cleveland Coxe, D.D. Buffalo: The Christian Literature Publishing Company, 1885-96

ROBINSON, Douglas. Western Translation Theory. 2. ed. Manchester / Northampton: St. Jerome Publishing, 2002

ROSENTHAL, Franz. A Grammar of Biblical Aramaic. Wiesbahen: Harrassowitz, 1983

SAND, Shlomo. A invenção do povo judeu. São Paulo: Benvirá, 2011

SANTALA, Risto. The Midrash of the Messiah: The Messiah and His Meal in Midrash Ruth Chapters V, VII and VIII and its roots and reflections in corresponding Jewish literature

SAPIR HEBREW-HEBREW. מילון עברי-עברי בשיטת ההווה] [Dicionário HebraicoHebraico pelo método atual]. Prolog Ltd. (C), 2012. iPAD

SAYÃO, Luiz. NVI: A Bíblia do século 21. São Paulo: Editora Vida, 2001

SCARDELAI, Donizete. Da Religião Bíblica ao Judaísmo Rabínico. São Paulo: Paulus, 2008

SCARDELAI, Donizete. Movimentos Messiânicos no Tempo de Jesus. São Paulo: Paulus, 1998

SKARSAUNE, Oskar. ’̀ Sombra do Templo: as influências do judaísmo no cristianismo primitivo. São Paulo: Vida, 2004

SCHAFF, Philip, D.D., LL.D. A Select Library of the nicene and post-nicene fathers of Christian church. New York: The Christian Literature Publishing Company, 1887-94

- A Select Library of Nicene and post-nicene fathers of Christian church: second series. New York: The Christian Literature Publishing Company, 1890-1900

SCHARFSTEIN, Zevi. Shilo Prayer Book. 4. ${ }^{\text {a }}$ Ed. New York: Shilo Publishing House, 1932

SCHOCHET, Jacob Immanuel. Mashiach: the principle of mashiach and the messianic era in jewish law and tradition. Expanded Edition. New York / Toronto: S.I.E., 1992

SCHOLEM, Gershom. As grandes correntes da mística judaica. São Paulo: Editora 
Perspectiva, 1972.

SONCINO BABYLONIAN TALMUD. Translated into english with notes, under the editorship of rabbi dr. I. Epstein, b.a., ph.d., d. Lit. Londres: the Soncino Press London, 1956, versão eletrônica disponível em: $<$ http://www.come-andhear.com/talmud/index.html> acesso em: 10.03.2011

ŞERBAN, A. Translation and Genre: Sacred Texts. In: Encyclopedia of Language \& Linguistics. 2. ed. Michigan: Elsevier, 2006

SHAKED, Guershon. Quem é culpado? Ruptura das convenções na observação da temática do holocausto. in: Cadernos de Língua e Literatura Hebraica. Vol. 2. São Paulo: Humanitas, 1999

SHEVOEL, Rav Haim Dov (org.). Kotvey Rabyno Moshé ben Nachman. [hebraico]. Jerusalém, Israel: Musar Harav Kook, 1963

SILVA, Esequias Soares da. Testemunhas de Jeová: a Inserção de Suas Crenças no Texto da TRADUÇÃO DO NOVO MUNDO DAS ESCRITURAS SAGRADAS. São Paulo, 2007, 196 f. Dissertação (Mestrado Ciências da Religião) - Universidade Presbiteriana Mackenzie

SILVA, Cássio Dias Murilo da. Metodologia da Exegese Bíblica. São Paulo: Paulinas, 2000

SIMON-SHOSHAN, Moshe. The tasks of the translators: the Rabbis, the Septuagint, and the Cultural Politics of Translation. In: Prooftexts 27 (2007), p. 1-39. Indiana: Indiana University Prees, 2007

SPENCE, Very Rev. H. D. M.; EXELL, Rev. Joseph S.; (editores). The Pulpit Commentary. Vol. 10 Isaiah. Michigan: WM. B. Eerdmans Publishing Company, 1950

STEINER, George. Depois de Babel: questões de linguagem e tradução. Curitiba, PR: Editora UFPR, 2005

STERN, David H. A Bíblia Judaica Completa: o Tanakh [AT] e a B'rit Hadashah [NT]. São Paulo: Editora Vida, 2010

Manifesto judeu messiânico. Rio de Janeiro: Edições Comunidade Emanuel, 1989

STEVENSON, William B. Grammar of Palestinian Jewish Aramaic. Glasgow: Oxford University Press, 1999

SWELlENGREBEL, J. L. João Ferreira de Almeida: um tradutor português da Bíblia em Java. 2.a ed. Rio de Janeiro: JUERP, 1984

TAYLOR, Kenneth N.. The Living Bible. Parafraseada. Wheaton, Illinois: Tyndale House Publishers, 1971

THE NEW TESTAMENT THE GREEK TEXT UNDERLYING THE ENGLISH AUTHORISED VERSION OF 1611. England: Trinitarian Bible Society, 2005 
THEODOR, Erwin. Tradução: ofício e arte. São Paulo: Cultrix, 1976

TOV, Emanuel. Textual Criticism of the Hebrew Bible. 2 ed. Minneapolis / Assen: Fortress Press / Royal Van Gorcum, 1992 . The Greek \& Hebrew Bible: Collected Essays on the Septuagint. Leiden / Boston / Köln: BRILL, 1999

THACKERAY, Henry St John. A Grammar of the Old Testament in Greek According to the Septuagint. Vol I. Cambridge: Cambridge University Press, 1909

TRACKSTON, W. M. Introduction to Syriac: an elementary grammar with readings from syriac literature. Maryland, USA: IBEX Publishers, 1999

UVEELER, Luba e BRONZNICK, Norman M. Ha-Yesod, Fundamentals of Hebrew.Jerusalém/Nova Iorque: Feldheim Publishers, 1998

VANHOOZER, Kevin. Há um significado neste texto? Interpretação bíblica: os enfoques contemporâneos. São Paulo: Vida, 2005

VÁZQUEZ-AYORA, Gerardo. Introduccion a la traductología: curso básico de traduccíon. Washington, D.C.: Georgetown University Press, 1977

VENUTI, Lawrence. The translation studies reader. 2. ed. New York/London: Routledge, 2004

VERMES, Geza. Jesus e o Mundo do Judaísmo. Bíblica Loyola 17. São Paulo: Edições Loyola, 1996

VIRKLER, Henry. Hermenêutica Avançada: princípios e processos de interpretação bíblica. São Paulo: Editora Vida, 2007

WALDMAN, Berta. Tradução/Tradição: Haim Nahman Bialik. In: Cadernos de Lingua e Literatura Hebraica. N. ${ }^{o}$ 7. São Paulo: Targumim, 2009, p. 315-331

WALlACE, Daniel B. Gramática Grega: uma sintaxe exegética do Novo Testamento. São Paulo: EBR, 2009

WALTKE, Bruce K.; O’CONNOR, M. Introdução à Sintaxe do Hebraico Bíblico. São Paulo: Cultura Cristã, 2006

WATTS, John D. W. Word Biblical Commentary. Vol 24. Isaiah 1-33 (Revised Edition). USA: Nelson Reference \& Eletronic, 2005 . Word Biblical Commentary. Vol 25. Isaiah 34-66 (Revised Edition). USA: Nelson Reference \& Eletronic, 2005 
WEIS_ROSMARIN, Trude. Judaísmo e Cristianismo, as diferenças. São Paulo: Editora e Livraria Sêfer, 1995

WERBLOWSKY, R. J. Zwi. O messianismo na História Judaica. In: Vida e Valores do Povo Judeu. Série Estudos. São Paulo: Editora Perspectiva, 1999

WILSON, Robert R. Profecia e Sociedade no Antigo Israel. 2. ${ }^{\mathrm{a}}$ Ed. São Paulo: Paulus/Targumim, 2006

WASSERSTEIN, Abraham; WASSERTEIN, David J. The Legend of the Septuagint: from Classical Antiquity to Today. Cambridge: Cambridge University Press, 2006

WÜRTHWEIN, Ernst. The text of the Old Testament. 2 ed. Michgan: Grand Rapids, 1995

YOFRE, Horácio Simian (org.). Metodologia do Antigo Testamento. Coleção Bíblica Loyola 28. São Paulo, 2000

ZUCK, Roy B. A Interpretação Bíblica: meios de descobrir a verdade bíblica. Vida Nova. SP. 1994 